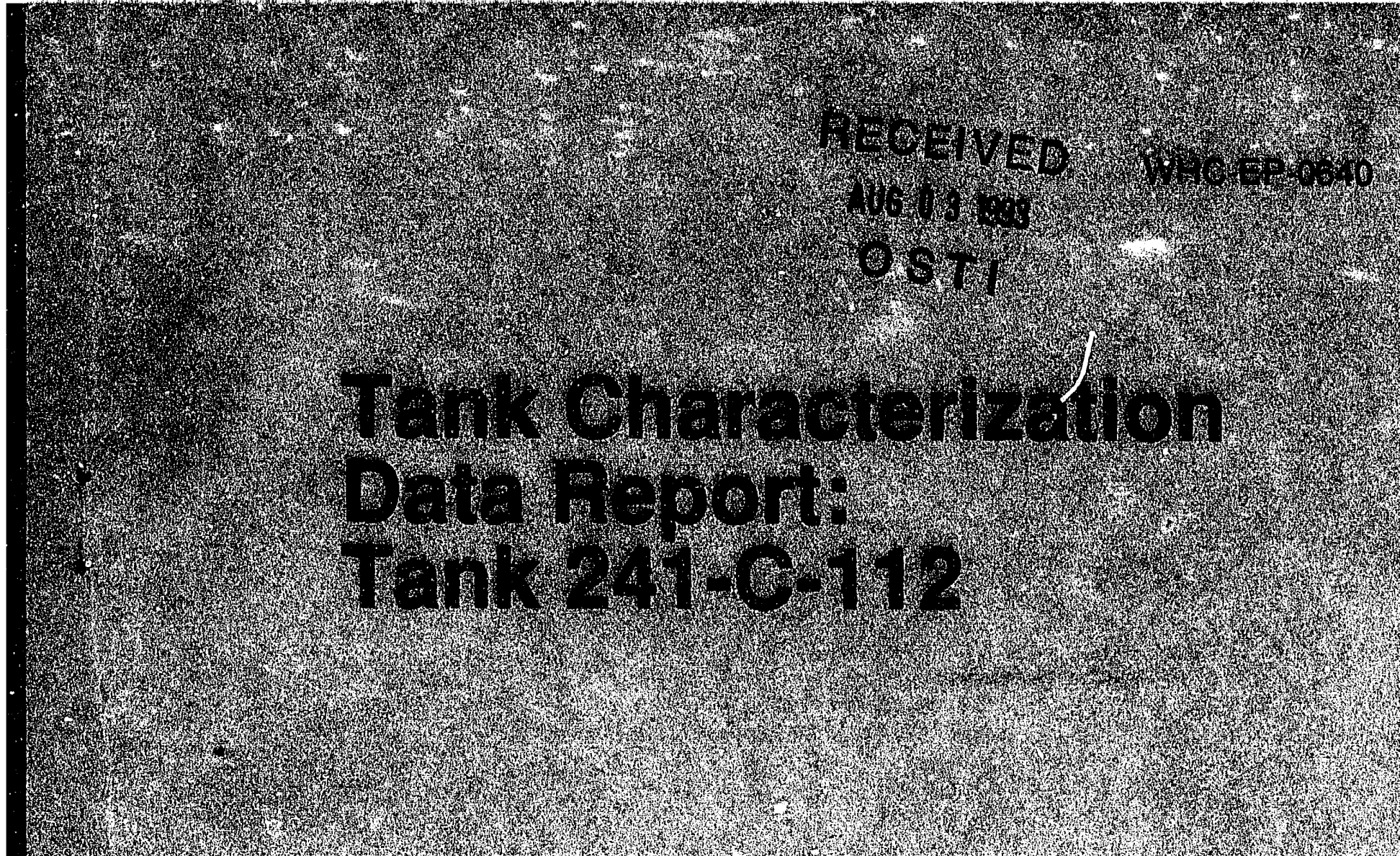

Prepared tor the US Dopaithent or Energy Oribe of Environnental Res ibration tand Wester Managenent

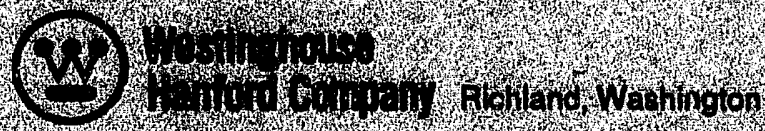

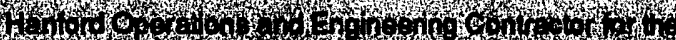

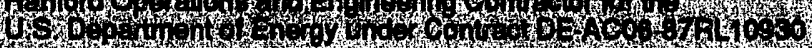


(5) $1001 \%$

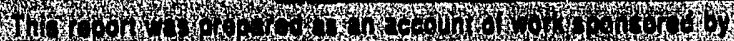

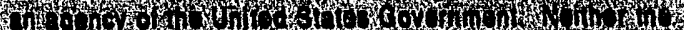

U.7.

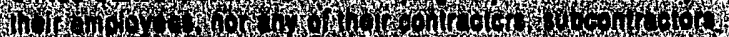

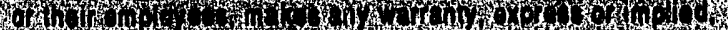
6 170 .

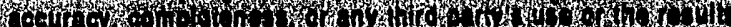

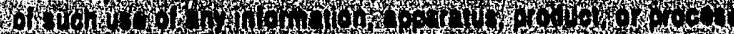

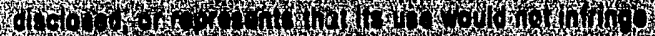

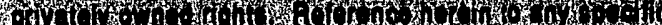
o. 7.

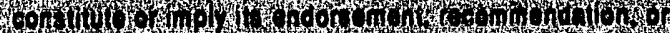

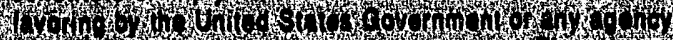

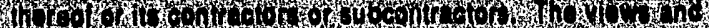

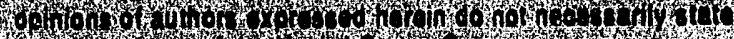

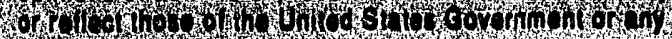

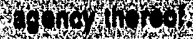

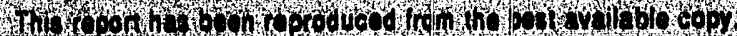

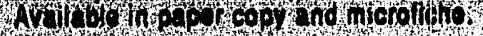

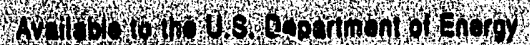

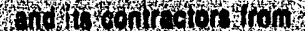

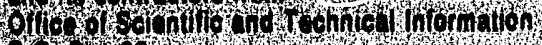

606060

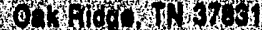

(7) 5 s $360 \%$

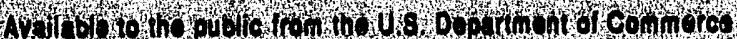

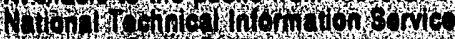

$30 \%$ on

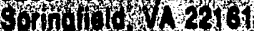

(70) 17,6060

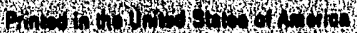

bisction toretion 
WHC-EP-0640

\section{Tank Characterization Data Report: Tank 241-C-112}

B. C. Simpson

G. L. Borsheim

L. Jensen

Date Published

April 1993

Prepared for the U.S. Department of Energy Office of Environmental Restoration and

Waste Management
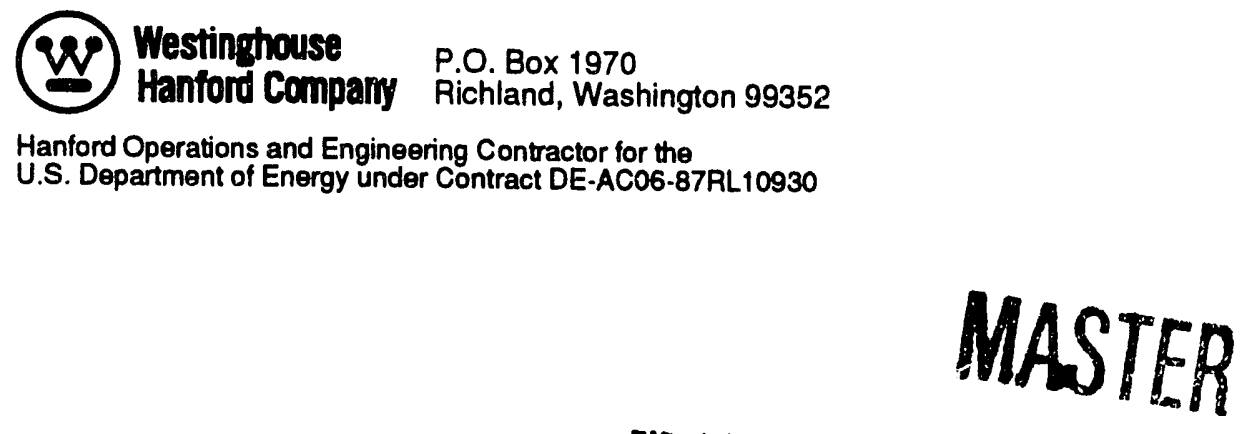

DSTRIBUTION OF THIS BOCUMERT IS UHLIMITE 
Document Title: Tank Characterization Data Report: Tank 24l-C-112

Prepared by: ButClimpin

Brett C. Simpson, Advanced Engineer

Analytical Evaluation and Reporting

Prepared by:

Approved by:

Approved by:

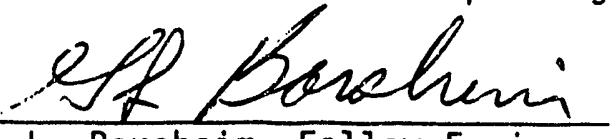

George L. Borsheim, Fellow Engineer

Tank Waste Technology Applications

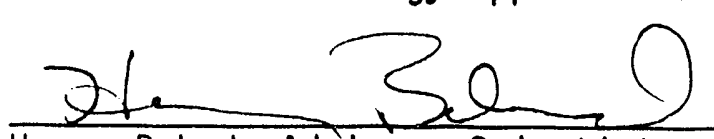

Harry Babad, Advisory Scientist

Waste Tank Safety Programs

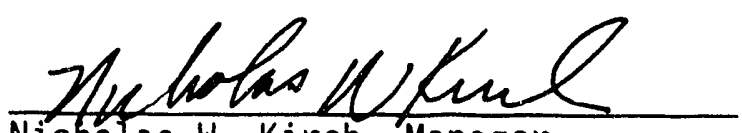

Nicholas W. Kirch, Manager

Tank Waste Technology Applications

Approved by:

Approved by:

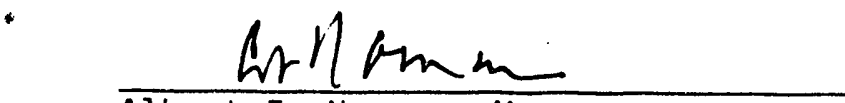

Albert F. Noonan, Manager

Analytical Evaluation and Reporting

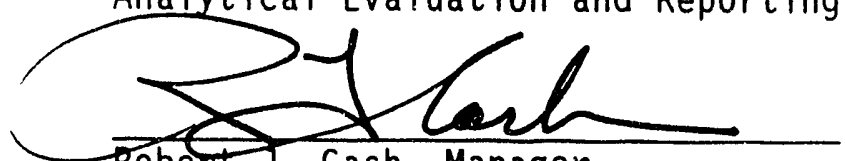

Robert . Cash, Manager

Ferrocyanide Safety Technology

Approved by:

Approved by:

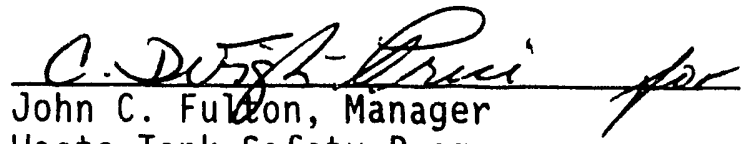
Waste Tank Safety Programs

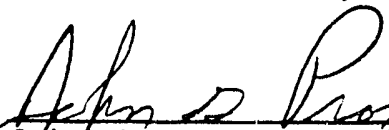

$36 \mathrm{hn} G$. Propson, Manager

Characterization and Safety Technology

Approved by:

Thoomas $E$ Whelan via Telecom fon Quality Assurance

Approved by:

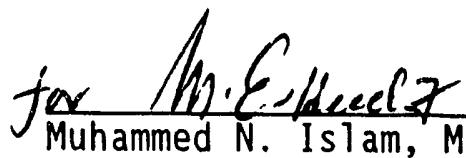

Muhammed N. Is lam, Manager

Waste Tank Safety Analys is $\frac{4 / 28 / 43}{\text { Date }}$

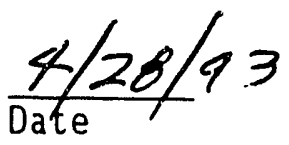

$\frac{4 / 28 / 93}{\text { Date }}$

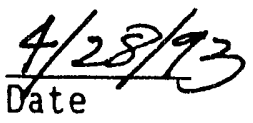

$\frac{4 / 28 / 53}{\text { Date }}$

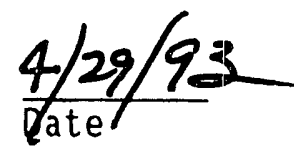

$\frac{4-28-93}{\text { Date }}$

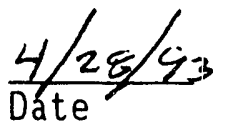

$\frac{4 / 28 / 93}{\text { Date }}$

$\frac{4-28-93}{\text { Date }}$ 


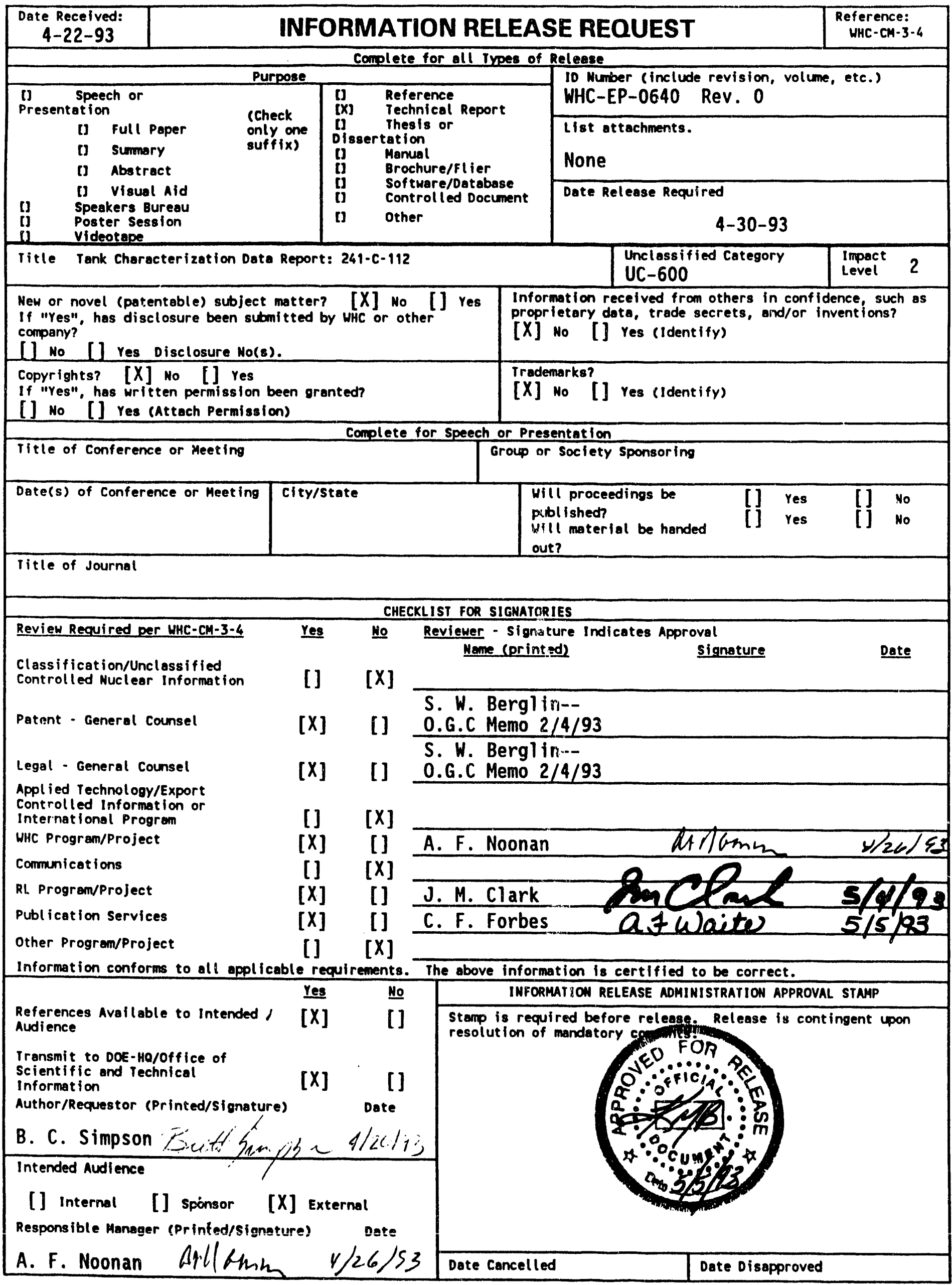




\section{EXECUTIVE SUMMARY}

Tank 241-C-112 is a Hanford Site Ferrocyanide Watch List tank that was most recently sampled in March 1992. Analyses of materials obtained from tank 241-C-112 were conducted to support the resolution of the Ferrocyanide Unreviewed Safety Question (USQ) and to support Hanford Federal Facility Agreement and Consent Order ${ }^{1}$ (Tri-Party Agreement) Milestone M-10-00.

Analysis of core samples obtained from tank 241-C-112 strongly indicates that the fuel concentration in the tank waste will not support a propagating exothermic reaction. It is probable that tank $241-C-112$ exceeds the 1,000 g-mol inventory criteria established for the Ferrocyanide USQ; however, extensive energetic analysis of the waste has determined a maximum exothermic value of $-9 \mathrm{cal} / \mathrm{g}$ dry waste. This value is substantially below any levels of concern $(-75 \mathrm{cal} / \mathrm{g})^{2}$. In addition, an investigation of potential mechanisms to generate concentration levels of radionuclides high enough to be of concern was performed. No credible mechanism was postulated that could initiate the formation of such concentration levels $s^{3}$ in the tank.

Tank 241-C-112 waste is a complex material made up primarily of water and inert salts. The insoluble solids are a mixture of phosphates, sulfates, and

\footnotetext{
${ }^{1}$ Ecology, EPA, and DOE, 1992, Hanford Federal Facility Agreement and Consent Order, 2 vols. Washington State Department of Ecology, U.S. Environmental Protection Agency, and U.S. Department of Energy, 0lympia, Washington.

2Jewett, J. R., 1992, "Energy Measurements for Disqual ifying Waste Tanks from Watch Lists," Meeting Minutes, October 22, 1992, Westinghouse Hanford Company, Richland, Washington.

${ }^{3}$ Dickinson, D. R., J. M. McLaren, G. L. Borsheim, M. D. Crippen, 1993, Credibility of Drying Out Ferrocyanide Tank Waste Slude by Hot Spots, WHC-EP-0648, Westinghouse Hanford Company, Richland, Washington.
} 
hydroxides in combination with aluminum, calcium, iron, nickel, and uranium. Disodium nickel ferrocyanide and sodium cesium nickel ferrocyanide probably exist in the tank; however, there appears to have been significant degradation of this material since the waste was initially settled in the tank. Most of the ${ }^{137}$ Cs precipitated during the scavenging campaign (1955 to 1957$)^{4}$ appears tc still remain in the tank in an insoluble form, probably bound with the remaining ferrocyanide. Total cyanide analyses substantiate the energetics results. The soluble analytes are primarily sodium, nitrate, and nitrite (Table ES-1).

Comparisons of the calculated bulk inventories for various analytes of concern show that tank 241-C-112 is within established operating safety requirements for heat-load, organics, and plutonium inventory. A substantial amount of free liquid remains in the tank. However, no effort to remove the remaining liquid is planned because there is less than $189,000 \mathrm{~L}(50,000 \mathrm{gal})$ of drainable liquid in the tank (thus meeting stabilization criteria). Tank 241-C-112 is considered a sound, non-leaking tank.

Analysis of the process history of the tank as well as studies of simulants provided valuable information about the physical and chemical condition of the waste. This information, in combination with the analysis of the tank waste, supports the conclusions that an exothermic reaction in tank 241-C-112 is not plausible. Therefore, the contents of tank 241-C-112 present no credible imminent threat to the workers at the Hanford Site, the public, or the environment from its ferrocyanide inventory. Because an exothermic

"Borsheim, G. L. and B. C. Simpson, 1991, An Assessment of the Inventories of the Ferrocyanide Watchlist Tanks, WHC-SD-WM-ER-133, Rev. 0 , Westinghouse Hanford Company, Richland, Washington. 
reaction is not credible, the consequences of this accident scenario, as promulgated by the General Accounting Office, are not applicable. ${ }^{5}$

Table ES-1.

\begin{tabular}{|c|c|c|c|c|c|c|c|c|c|c|c|}
\hline $\begin{array}{l}\text { Estimated Major } \\
\text { Analyte Inventory }\end{array}$ & Water & Ma & $\mathrm{MO}_{3}$ & u & $\mathrm{mo}_{2}^{\circ}$ & p & Fe & $\mathrm{Ca}_{2}$ & Mi & Al & TOC \\
\hline Wtx (wet solids) & 53.8 & 9.3 & 5.7 & 5.1 & 4.2 & 2.3 & 1.9 & 1.4 & 1.3 & 1.0 & 0.4 \\
\hline \multicolumn{6}{|c|}{ Estimated Fission Product Inventory } & \multicolumn{3}{|l|}{${ }^{137} \mathrm{Cs}_{5}$} & \multicolumn{3}{|l|}{${ }^{90} \mathrm{sr}$} \\
\hline \multicolumn{6}{|c|}{$\begin{array}{l}\text { Bulk Inventory, } \mathrm{Ci} \\
\text { (atr solides) }\end{array}$} & \multicolumn{3}{|c|}{217,200} & \multicolumn{3}{|c|}{183,500} \\
\hline \multicolumn{6}{|l|}{ Heat Generation, $w$} & \multicolumn{3}{|l|}{1025} & \multicolumn{3}{|c|}{1230} \\
\hline \multicolumn{3}{|c|}{$\begin{array}{l}\text { Estimated Plutoniua/ Americiua } \\
\text { Inventory }\end{array}$} & \multicolumn{3}{|l|}{${ }^{230} \mathrm{Pu}$} & \multicolumn{3}{|c|}{$239 / 260 \mathrm{Pu}$} & \multicolumn{3}{|c|}{${ }^{261} \mathrm{Am}$} \\
\hline \multicolumn{3}{|l|}{$\begin{array}{l}\text { Bulk Inventory, } \mathrm{Cl} \\
\text { (cals solios) }\end{array}$} & \multicolumn{3}{|l|}{5.9} & \multicolumn{3}{|l|}{67.3} & \multicolumn{3}{|l|}{330} \\
\hline \multicolumn{3}{|l|}{$\begin{array}{l}\text { Bulk Inventory, } 9 \\
\text { (ans collow }\end{array}$} & \multicolumn{3}{|l|}{0.34} & \multicolumn{3}{|l|}{1100} & \multicolumn{3}{|l|}{100} \\
\hline \multicolumn{12}{|l|}{$\cdot$} \\
\hline \multicolumn{3}{|l|}{ Analyte } & \multicolumn{6}{|c|}{ Safety Issue Criteria } & \multicolumn{3}{|c|}{$\begin{array}{l}\text { Calculated/Masured } \\
\text { Value }\end{array}$} \\
\hline \multicolumn{3}{|l|}{$\mathrm{Na}_{2} \mathrm{NiFe}(\mathrm{CN})_{0}$ (Here callias) } & \multicolumn{6}{|c|}{$1000 \mathrm{~g}-\mathrm{mol}$} & \multicolumn{3}{|c|}{$8,700 \mathrm{~g}-\mathrm{mol}$} \\
\hline \multicolumn{3}{|l|}{$\Delta H$ (dry basis) } & \multicolumn{6}{|c|}{$-75 \mathrm{cal}$} & \multicolumn{3}{|c|}{-9 cal } \\
\hline \multicolumn{3}{|l|}{$239 / 240 \mathrm{Pu}$} & \multicolumn{6}{|c|}{$50 \mathrm{~kg}$} & \multicolumn{3}{|c|}{$1.1 \mathrm{~kg}$} \\
\hline Tengerature & & & $300^{\circ} \mathrm{F}$ & $1149^{\circ}$ & & & & & $85^{\circ} \mathrm{F}$ & $\left.29^{\circ} \mathrm{C}\right)$ & \\
\hline Heat Load & & & 11.7 & $\mathrm{kw}$ & & & & & 2.26 & & \\
\hline $\begin{array}{l}\text { Organic Content } \\
\text { (TOC, dry basis) }\end{array}$ & & & $\begin{array}{l}3.0 \\
\operatorname{cios}:\end{array}$ & tx TO & onir & & & & 0.75 & t\% 10 & \\
\hline
\end{tabular}

${ }^{5}$ Peach, J. D., 1990, "Consequences of Explosion of Hanford's Single-Shell Tank are Understated," (Letter B-241479 to C. M. Synar, Chairman of Environment, Energy, and Natural Resources Subcommittee, Committee on Government Operations, House of Representatives), GAO/RCED-91-34, General Accounting office, Washington, D.C. 
WHC-EP-0640

This page intentionally left blank. 


\section{CONTENTS}

1.0 INTRODUCTION . . . . . . . . . . . . . . . . . . 1-1

1.1 PURPOSE . . . . . . . . . . . . . . . . . . . . 1-1

1.2 APPROACH ....................... . . . . . . . . . .

2.0 PRESAMPLING INFORMATION AND EVALUATION . . . . . . . . . . . . 2-1

2.1 BACKGROUND ....................... . . . . . . . .

2.1.1 Tank 241-C-112 History . . . . . . . . . . . . . . . . . 2-1

2.1 .2 Unreviewed Safety Question Declaration . . . . . . . . . 2-6

2.3 EXPECTED TANK CONTENTS/CONDITIONS

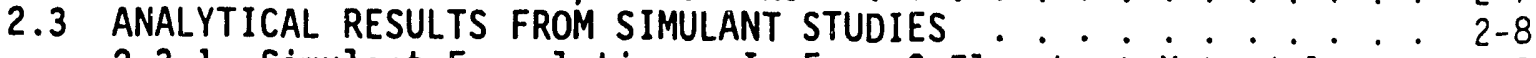

2.3.1. Simulant Formulation: In Farm 2 Flowsheet Material . $2-8$

2.3.2 Physical Characteristics............. 2-9

2.3.3 Chemical Composition ................ . 2-10

2.3.4 Energetics Behavior of Ferrocyanide siudge Simulant . $2-10$

3.0 CORE SAMPLING . . . . . . . . . . . . . . . . . . . . . $3-1$

3.1 DESCRIPTION OF SAMPLING EVENT . . . . . . . . . . . . . . . . . . . . . $3-1$

3.2 CHAIN OF CUSTODY . . . . . . . . . . . . . . . . . . . $3-1$

4.0 SAMPLE PREPARATION/SAMPLE EXTRUSION .................... . . $4-1$

4.1 DESCRIPTION OF GAMMA SCANNING EFFORT . . . . . . . . . . . . . . . . 4 .

4.1.1 Core 34 ....................... . . . . . . .

4.1 .2 Core 35 . . . . . . . . . . . . . . . . . . . . . . . $4-1$

4.1.3 core 36 . . . . . . . . . . . . . . . . . . . . . . 4-4

4.1.4 Tank 241-C-112 Gamma Scanning Summary . . . . . . . . . 4-4

4.2 DESCRIPTION OF SAMPLE HANDLING AND ANALYTICAL SCHEME . . . . . . . $4-6$

4.2.1 Sample Breakdown Procedure . . . . . . . . . . . . . . 4-6

4.2.2 Homogenization Tests................... . . . . . $4-7$

4.2.3 Subsegment-Level Analyses . . . . . . . . . . . . . . . 4-7

4.2.4 Rheological and Physical Measurements . . . . . . . . . 4-9

4.2.5 Subsegment Level Archive ........... . . . . . 4-9

4.2.6 Core Composite Level Analysis . . . . . . . . . . . . . 4-10

5.0 ANALYTICAL RESULTS: TANK 241-C-112

5.1 TANK 241-C-112 CORE SAMPLE RECOVERY . . . . . . . . . . . . . . . $5-1$

5.2 TANK 241-C-112 CORE SAMPLE RHEOLOGICAL/PHYSICAL MEASUREMENTS . $5-3$

5.2.1 Shear Strength ................ 5-7

5.2.2 Viscosity as a Function of Shear Rate . . . . . . . . 5-7

5.2.3 Slurry Flow Properties . . . . . . . . . . . . . . . 5-9

5.2.4 Particle Size Measurement . . . . . . . . . . . . . . . 5-9

5.3 ANALYTICAL RESULTS--INDUCTIVELY COUPLED PLASMA-

ATOMIC EMISSION SPECTROSCOPY . . . . . . . . . . . . . 5-15

5.3.1 Inductively Coupled Plasma Assays--General Comments . . 5-15

5.3.2 Core 34 ................ . . 5-20

5.3 .3 Core 35 ................. . . $5-20$

5.3.4 Core 36 . . . . . . . . . . . . . . . . . . . . . 5-21

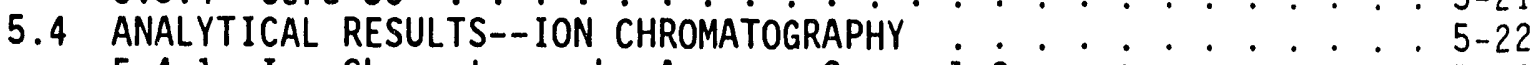

5.4.1 Ion Chromatography Assays--General Comments . . . . . . 5-22

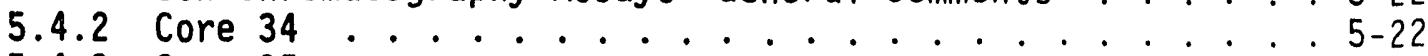

5.4 .3 Core 35 . . . . . . . . . . . . . . . . . . . . 5-25

5.4 .4 Core 36 . . . . . . . . . . . . . . . . . 5-26 


\section{CONTENTS (Continued)}

5.5 ANALYTICAL RESULTS--RADIOCHEMISTRY . . . . . . . . . 5-26

5.5.1 Radiochemistry Assays--General Comments . . . . . . 5-26

5.5.2 Core 34 Radiochemistry . . . . . . . . . . . . . . . 5-29

5.5.3 Core 35 Radiochemistry . . . . . . . . . . . . . . 5-29

5.5.4 Core 36 Radiochemistry . . . . . . . . . . . . . . 5-29

5.6 ANALYTICAL RESULTS--ENERGETICS . . . . . . . . . . . . . . . . 5-29

5.6.1 Remarks on the Interpretation of Differential

Scanning Calorimetry/Thermogravimetric

Analys is Data ............ . . 5-30

5.6.2 General Comments on the Differential

Scanning Calorimetry/Thermogravimetric

Analys is Behavior of the Samples . . . . . . . . . . 5-33

5.7 ANALYTICAL RESULTS - POTENTIAL WASTE CONSTITUENTS . . . . . . . 5-36

5.7.1 Mass Balances .. . . . . . . . . . . . . . . . . 5-36

5.7.2 Suggested Components of Waste Matrix . . . . . . . . . . 5-38

5.7.3 Comparison to Theoretical Estimates

and Simulant Studies ............ . . 5-39

6.0 INTERPRETATION OF ANALYTICAL RESULTS ............... . . 6-1

6.1 TANK 241-C-112 WASTE PROFILE . . . . . . . . . . . . . . . . 6-1

6.2 REVIEW OF THE SUBSEGMENT ANALYTE PROFILES . . . . . . . . . . . 6-2

6.2.1 Tank Entrance/Exit Effects

on Analyte Distribution ............ . 6-3

6.2.2 Comparisons with the Borsheim/

Simpson Model Estimates . . . . . . . . . . . . . . 6-6

6.3 CALCULATED BULK INVENTORIES OF SELECTED ANALYTES . . . . . . . $6-8$

6.4 GAMMA SCANNING OF CORE SAMPLE SEGMENTS . . . . . . . . . . . . . $6-9$

7.0 QUANTITATIVE/STATISTICAL INTERPRETATION OF THE DATA . . . . . . . . 7 - ]

7.1 CONCENTRATION ESTIMATES . . . . . . . . . . . . . . 7-2

7.2 HOMOGENIZATION TESTS . . . . . . . . . . . . . . . . . . 7-6

7.3 COMPARISON BETWEEN THE SIMULATED CORE

COMPOSITE AND THE CORE COMPOSITE . . . . . . . . . . . . . 7-8

7.3.1 Core 36 Statistical Methods .. . . . . . . . . . . . 7-8

7.3.2 Core 34 Statistical Methods .. . . . . . . . . . . . . 7-9

7.3.3 Results from Cores 34 and 36 ... . . . . . . . . . . . 7-9

7.4 SPATIAL VARIABILITY AND ANALYTICAL ERROR ESTIMATION . . . . . . 7-9

8.0 CONCLUSIONS AND RECOMMENDATIONS ................. 8-1

8.1 ANALYTICAL RESULTS . . . . . . . . . . . . . . . . . 8-1

8.2 ENERGETICS ANALYSIS . . . . . . . . . . . . . . . . . . . 8-2

8.3 RECOMMENDATIONS .................... . 8 . . . 3

9.0 REFERENCES ......................... 9-1 
WHC-EP-0640

APPENDIXES

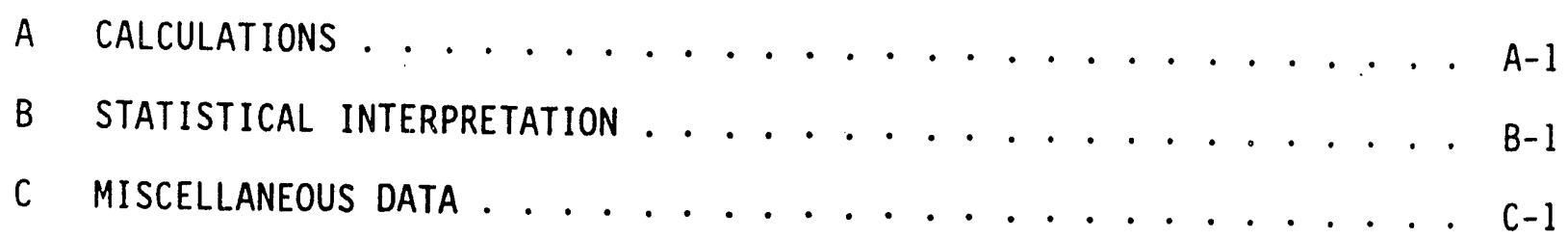


WHC-EP-0640

\section{LIST OF FIGURES}

2-1 Typical Single-Shell Tank Diagram ............ 2-2

2-2 In Farm Flowsheet.................. 2-4

2-3 Ferrocyanide Tank 3-Component Diagram . . . . . . . . . 2-12

3-1 Tank 241-C-112 Riser Configuration ........... 3-2

4-1 241-C-112 Gamma Scanning, Core 34 Results ........... . . 4-2

4-2 241-C-112 Gamma Scanning, Core 35 Results ........... 4-3

4-3 241-C-112 Gamma Scanning, Core 36 Results . . . . . . . . . 4-5

4-4 Typical Single-Shell Tank Segment Extrusion . . . . . . . . . 4-6

5-1 Current Condition of Tank 241-C-112 . . . . . . . . . 5-2

5-2 Segments 1 and 2, Core 34 Measurements and Observations . . . . 5-4

5-3 Segments 1 and 2, Core 35 Measurements and Observations..... 5-5

5-4 Segments 1 and 2, Core 36 Measurements and Observations . . . . . 5-6

5-5 Core 34, Particle Size Number Density . . . . . . . . . . . 5-11

5-6 Core 36 , Particle Size Number Density . . . . . . . . . . . 5-11

5-7 Single-Shell Tank Core 34, Particle Size

5-8 Single-Shell Tank Core 36, Particle Size

Volume Density ............... . 5-13

5-9 Settling Rate Data for Tank 241-C-112 Core 36, 1:1 Dilution . . . . 5-16

5-10 Settling Rate Data for Tank 241-C-112 Core 36, 3:1 Dilution. . . 5-16

6-1 Elevation and Plan of Tank 241-C-112 ............ 6-4

6-2 Waste Profile of Tank 241-C-112 ............. 6-5 
WHC-EP-0640

\section{LIST OF TABLES}

2-1 Feed Solution Composition for In Farm 2 Flowsheet . . . . . . . 2-8

2-2 Summary of In Farm 2 Characterization Data .......... . 2-9

2-3 Estimated Composition of Homogenized, Centrifuged,

Ferrocyanide Sludge Simulant . . . . . . . . . . . . 2-10

2-4 Heats of Reaction of Various Simulants ............. 2-11

4-1 Subsegment-Level Analysis ................. 4-8

5-1 Tank 241-C-112 Core Sample Description Summary .. . . . . . . . 5-1

5-2 Tank 241-C-112 Core Sample Physical Characteristics Summary . . . . 5-3

5-3 Power-Law Model Parameters for Tank 241-C-112 Material . . . . . 5-8

5-4 Turbulent Flow Model Calculations . . . . . . . . . . . . 5-9

5-5 Particle Size Distribution by Number: $97 \%<2 \mu \mathrm{m}$ (both cores) . . 5-10

5-6 Particle Size Distribution by Volume:

$100 \%<30 \mu \mathrm{m}(34-2 \mathrm{D}) ; 100 \%<85 \mu \mathrm{m}(36)$. . . . . . . . . . . $5-10$

5-7 Physical Properties Summary ................ . 5-14

5-8 Water Digestion Chemical Composite Data--ICP Average Values . . . 5-17

5-9 Acid Digestion Chemical Composite Data--ICP Average Values . . . . 5-17

5-10 Fusion Digestion Chemical Composite Data--ICP Average Values . . 5-18

5-11 Tank 241-C-112 Core 34 ICP Analyte Trending (fusion prep on subsegments) .............. 5-18

5-12 Tank 241-C-112 Core 35 ICP Analyte Trending (fusion prep on subsegments) .............. 5-19

5-13 Tank 241-C-112 Core 36 ICP Analyte Trending (fusion prep on subsegments) ............... . 5-19

5-14 Ion Chromatography--Composite Data Results (water leach) . . . . 5-23

5-15 Tank 241-C-112 Core 34 IC Analyte Trending . . . . . . . . . . . . 5-23

5-16 Tank 241-C-112 Core 35 IC Analyte Trending . . . . . . . . . . . 5-24

5-17 Tank 241-C-112 Core 36 IC Analyte Trending . . . . . . . . . . . 5-24

5-18 Tank 241-C-112 Core 34 Misc. Analyte Trending . . . . . . . . . . 5-24 


\section{LIST OF TABLES (Continued)}

5-19 Tank 241-C-112 Core 35 Misc. Analyte Trending . . . . . . . . . . 5-25

5-20 Tank 241-C-112 Core 36 Misc. Analyte Trending . . . . . . . . . . 5-25

5-21 Core Composite Fission Products (fusion prep) . . . . . . . . 5-27

5-22 Core Composite Uranium . . . . . . . . . . . . . . . 5-27

5-23 Core Composite Transuranics (fusion preparation) . . . . . . . 5-27

5-24 Tank 241-C-112 Core 34 Radionuclide Trending (fusion preparation) . 5-28

5-25 Tank 241-C-112 Core 35 Radionuclide Trending (fusion preparation) . 5-28

5-26 Tank 241-C-112 Core 36 Radionuclide Trending (fusion preparation) ............. . . 5-28

5-27 Thermogravimetric Analysis Results from Tank 241-C-11乞 ............... 5-31

5-28 Differential Scanning Calorimetry Energetics Results from Tank 241-C-112.............. . 5-32

5-29 Tank 241-C-112 Core 34 Energetic Comparison . . . . . . . . . . 5-33

5-30 Tank 241-C-112 Core 36 Energetic Comparison . . . . . . . . . 5-34

5-31 Tank 241-C-112 Core 34 Energetics Trending . . . . . . . . 5-35

5-32 Tank 241-C-112 Core 35 Energetics Trending . . . . . . . . 5-35

5-33 Tank 241-C-112 Core 36 Energetics Trending . . . . . . . . . 5-35

5-34 Adjusted Mass Balance: Core 34 Composite . . . . . . . . . . . 5-37

5-35 Adjusted Mass Balance: Core 35 Composite . . . . . . . . . 5-37

5-36 Adjusted Mass Balance: Core 36 Composite . . . . . . . . . . 5-38

5-37 Probable Solids in the Waste Matrix . . . . . . . . . . . 5-38

5-38 Tank 241-C-112 Comparison of Waste Material
with Simulants for Selected Analytes . . . . . . . . . . . . 5-40

6-1 Comparisons of Initial and Revised Borsheim/Simpson Model Estimates with Values Calculated from Analytical Results ................ . . 6-6

6-2 Energetics Related Analyte Values . . . . . . . . . . . 6-8 


\section{LIST OF TABLES (Continued)}

6-3 Fission Product Inventory .............. 6-. 6 . . .

6-4 Plutonium/Americium Inventory ............ 6- . . . . . .

6-5 ICP Major Cation Inventory (Fusion Preparation) . . . . . . . 6-9

7-1 Acid Digestion Inventory Statistics $(\mu \mathrm{g} / \mathrm{g}) \ldots \ldots$. . . . . . .

7-2 Potassium Hydroxide Fusion Dissolution Inventory Statistics $(\mu \mathrm{g} / \mathrm{g}) \quad 7-4$

$7-3$ Water Leach Inventory Statistics $(\mu \mathrm{g} / \mathrm{g}) \ldots \ldots$. . . . . . . 7-5

$7-4$ Radiochemistry Statistics $(\mu \mathrm{Ci} / \mathrm{g}) \ldots \ldots$. . . . . . 7-6

7-5 Ion Chromatography Anion Statistics $(\mu \mathrm{g} / \mathrm{g}) \ldots \ldots$. . . . . . .

7-6 Homogenization Test Results ............. 7-7

7-7 Segment vs. Composite Statistics for Core 34 . . . . . . . . 7-10

7-8 Segment vs. Composite Statistics for Core 36 . . . . . . . 7-11

7-9 Acid Digestion Spatial and Analytical Error Estimates . . . . . . 7-13

7-10 Water Leach Spatial and Analytical Error Estimates . . . . . . 7-14

7-11 Potassium Hydroxide/Nickel Fusion Dissolution Spatial and Analytical Error Estimates .......... . 7-15

7-12 Radiochemistry Spatial and Analytical Error Estimates..... 7-15

7-13 Ion Chromatography Anion Spatial and Analytical Error Estimates . 7-15

8-1 Comparison of Tank 241-C-112 Analyte Values to Safety Issue Criteria ............... . . 8-3 
WHC-EP-0640

This page intentionally left blank. 


\section{LIST OF ACRONYMS}

$1 C$

$A A$

AEA

ANOVA

CI

CST

DLC

DSC

GAO

GEA

HASM

HDW-EIS

IC

ICP

PNL

RPD

SST

TC

TGA

TIC

TOC

TOD

Tri-Party

Agreement

UR

USQ first decontamination cycle

atomic absorption

alpha energy analysis

analysis of variance

confidence interval

core sampling truck

drainable liquid composites

differential scanning calorimetry

General Accounting office

gamma energy analys is

Hanford Analytical Services Management

Final Environmental Impact Statement, Disposal of Hanford Defense High-Level, Transuranic and Tank Wastes

ion chromatography

inductively coupled plasma - atomic emission spectroscopy

Pacific Northwest Laboratory

relative percent difference

single-shell tank

total carbon

thermogravimetric analysis

total inorganic carbon

total organic carbon

total oxygen demand

Hanford Federal Facility Agreement and Consent Order uranium recovery

unreviewed safety question 
This page intentionally left blank. 
TANK CHARACTERIZATION DATA REPORT: TANK 241-C-112

\subsection{INTRODUCTION}

Analysis was conducted on materials obtained from tank $241-C-112$ to support the resolution of the ferrocyanide unreviewed safety question (USQ). obtaining measurements that determine overall waste energetics is a key step in resolving the ferrocyanide USQ and safety issue. In addition, several of the analytes contributing to the energetic properties of the waste need to be measured as a function of position (e.g., total cyanide and nitrate/nitrate present, water content, and the distribution and inventory of ${ }^{137} \mathrm{Cs}$ and ${ }^{90} \mathrm{Sr}$ in the tank). Other objectives that these measurements and inventory estimates support are as follows.

- Complete Hanford Federal Facility Agreement and Consent Order (Tri-Party Agreement) Milestone M-10-00 (Ecology et al. 1992) to sample and analyze two cores from each tank.

- Obtain estimates of both the concentration and total quantity of key analytes relating to other safety issues, such as organics and radionuclides.

- Provide input to risk assessment-based disposal decisions for the waste.

- Implement physical property measurements, such as rheology, bulk density, and particle size. These measurements are necessary for the design and fabrication of retrieval, pretreatment, and final waste disposal systems.

\subsection{PURPOSE}

This report summarizes the available information regarding the waste in tank 241-C-112, and arranges this information in a useful format for data users in various internal and external organizations.

\subsection{APPROACH}

This report presents a broad background of preliminary information that was available prior to core sampling, and which initially guided the development of the sampling and analysis program. This material includes historical information about the ferrocyanide-scavenging program, transfer records, observations from in-tank photographs, and inferences from waste simulant studies. The results of tank 241-C-112 core sample analyses are summarized and presented, along with a statistical interpretation of the data. The information obtained from historical sources and synthetic waste studies will be compared with the actual waste measurements in this report. 
WHC-EP-0640

This page intentionally left blank. 


\subsection{PRESAMPLING INFORMATION AND EVALUATION}

\subsection{BACKGROUND}

Radioactive wastes from defense operations have accumulated at the Hanford Site in underground waste tanks since the 1940's. During the 1950's, additional tank storage space was required to support the United States defense mission. To obtain additional tank storage volume within a short period of time and to minimize construction of additional storage tanks, Hanford Site scientists developed a process to scavenge radiocesium from tank waste liquids (Sloat 1954, Abrams 1956). Ferrocyanide compounds were used in a carrier-precipitation process to scavenge ${ }^{137} \mathrm{Cs}$ and other soluble radionuclides from the Hanford Site waste tanks. This treatment was used on $U$ Plant waste effluent, bismuth phosphate first-cycle decontamination waste, and selected wastes that had been previously discharged to the tanks. The radionuclides settled in the waste tanks and the supernate was discharged to the cribs and trenches. As a result of this process, occupied waste volume in the waste tanks was greatly reduced, while minimizing the amount of long-lived radionuclides discharged to the ground.

In implementing this process, approximately 140 metric tons of ferrocyanide [as $\mathrm{Fe}(\mathrm{CN})_{6}^{-4}$ ] were added to the tanks. The bulk of the ferrocyanide material is believed to remain in 18 to 24 single-shell tanks (SSTs). Ferrocyanide is a stable complex of iron(II) ion and cyanide, whose compounds are considered nontoxic because they do not appreciably dissociate in aqueous solutions (Burger 1984). In the presence of oxidizing materials such as nitrates and/or nitrites, ferrocyanide compounds can undergo uncontrolled exothermic reactions in the laboratory by heating them to high temperatures (above $\left.280^{\circ} \mathrm{C}\left[540^{\circ} \mathrm{F}\right]\right)$. The reactive nature of ferrocyanide in the presence of an oxidizer has been known for decades, but the conditions under which the compound can undergo exothermic reactions have not been thoroughly studied. Because the scavenging process involved precipitating ferrocyanides from solutions containing nitrate and nitrite, the potential for a reactive mixture of ferrocyanides and nitrates/nitrites in the SSTs must be evaluated.

\subsubsection{Tank 241-C-112 History}

Groups of waste tanks that were physically located together and built at the same time are called tank farms at the Hanford Site. The original tank farms (B, C, T, U) were built in 1943-1944. Tank 241-C-112 was placed into service in 1946. Each tank has a diameter of $22.9 \mathrm{~m}(75 \mathrm{ft})$, an operating depth of $5.2 \mathrm{~m}(17 \mathrm{ft})$, and a nominal capacity of 2 million ititers $(530,000 \mathrm{gal})$. The basic design of a typical SST is shown in Figure 2-1. The tank was constructed of reinforced concrete with a mild steel liner covering its bottom and sides. The top of the tank is a concrete dome. Tanks such as 241-C-112 were all covered by at least $1.8 \mathrm{~m}(6 \mathrm{ft})$ of soil for shielding purposes (Anderson 1990). The tanks in the tank farms were connected in groups of three or four and overflowed from one to another (known as a cascade). Tank $241-C-112$ is the last tank in a cascade that includes $241-C-110$ and $241-C-111$. 
Figure 2-1. Typical Single-Shell Tank Diagram.

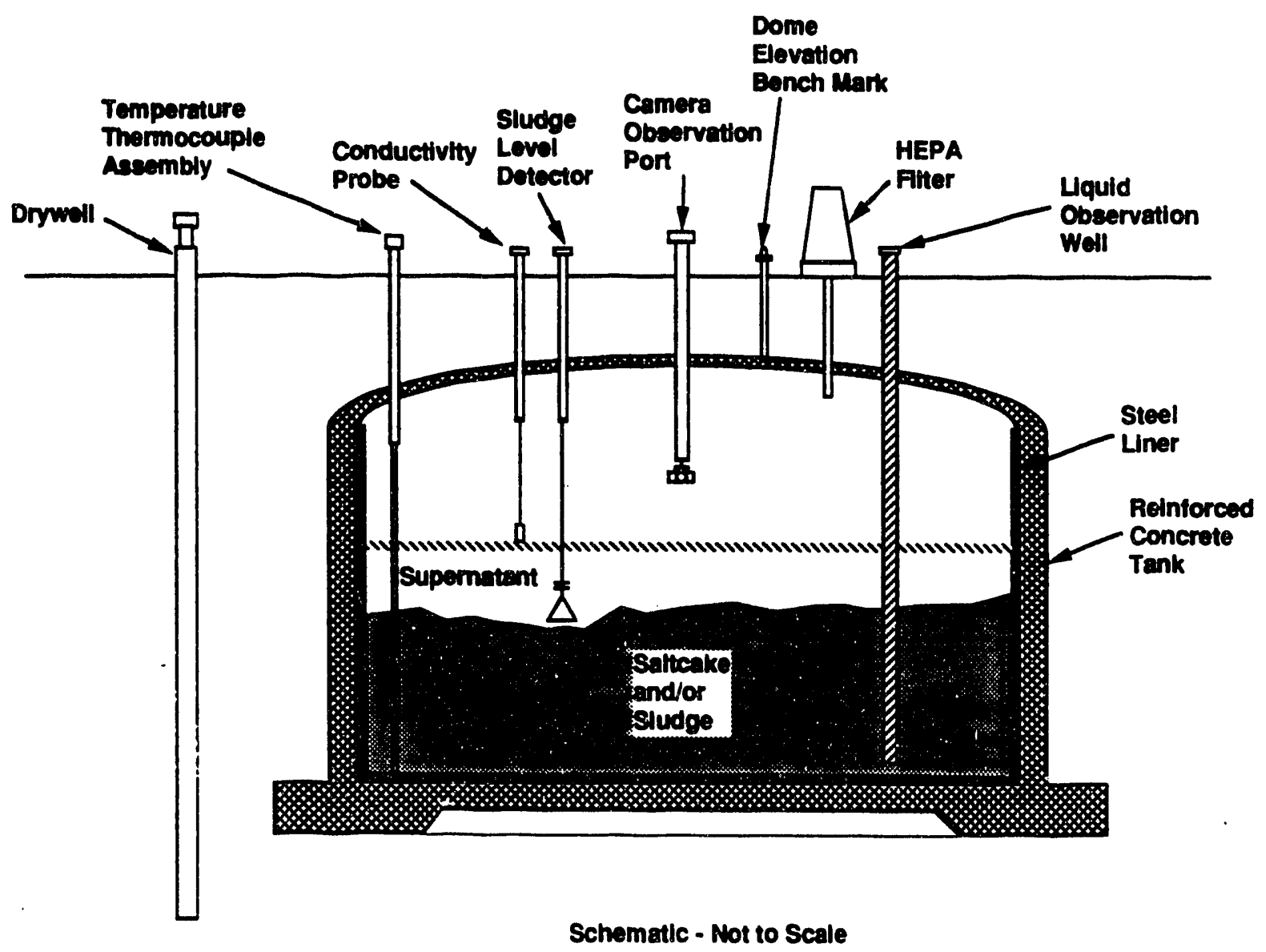

28905008.2

Note: Tank 241-C-112 has a dished bottom. 
Cascades served several functions in Hanford Site waste management operations. By cascading tanks, fewer connections needed to be made during waste disposal; consequently, all three tanks were usable without having to connect the active waste transfer line directly to each individual tilk. This handling method reduced the likelihood for personnel exposure to the waste and diminished the chances for a loss of tank integrity due to overfilling. Another benefit of the cascades was clarification of the wastes. When used in this manner, most of the solids in the waste slurries routed to the tanks settled in the first tank $(241-C-110)$, and the clarified liquids cascaded on to the other tanks in the series $(241-c-111$ and $241-c-112)$. Supernate from the final tank in a cascade series was sometimes routed to a disposal trench. In this way clarification reduced the potential amount of radiological contamination to ti.e environment.

The first type of waste that tank $241-C-112$ received and stored was first-cycle decontamination waste from the bismuth phosphate process (1946 to 1952). This waste would be comparatively high in bismuth, phosphate, and aluminum because aluminum decladding waste was combined with it. The waste was disposed to ground in 1952, leaving a 57,000-L (15,000-gal) heel. The tank was refilled with unscavenged uranium recovery (UR) waste in 1953 and 1954 (Anderson 1990). The UR waste solids were comparatively high in uranium and iron, and low in bismuth and aluminum. The available records do not show whether these wastes were added directly to the tank or through the cascade overflow line from tank $241-C-111$. Neither of these waste types had any significant fuel content, ${ }^{137} \mathrm{Cs}$ or ${ }^{90} \mathrm{Sr}$, that could contribute to the exothermic potential posed by the ferrocyanide wastes. In late 1955, tank 241-C-112 was emptied. The tank was then used for settling scavenged ferrocyanide waste until 1958. During ferrocyanide-scavenging operations, waste was not cascaded through the $241-C-110,-111,-112$ series. Tank 241-C-112 received the waste slurry in direct transfers from the process vessel (General Electric 1958).

Beginning in May 1955, unscavenged UR waste already stored in 200 East Area underground tanks at the Hanford Site was routed to the 244-CR vault for scavenging (refer to Figure 2-2). The 244-CR vault facility contained stainless steel tanks with chemical addition, agitation, and sampling capabilities. The $\mathrm{pH}$ was adjusted with $\mathrm{HNO}_{3}$ and/or $\mathrm{NaOH}$ to $\mathrm{pH} 9.3 \pm 0.7$, and $\mathrm{Fe}(\mathrm{CN})_{6}^{-4}$ and $\mathrm{Ni}^{+2}$ ion were added (generally to $0.005 \mathrm{M}$ each) to precipitate ${ }^{137} \mathrm{Cs}$. If laboratory analys is of the feed tank indicated additiona? ${ }^{90} \mathrm{Sr}$ decontamination was necessary, calcium nitrate was also added (Sloat 1955). There was also an effort to scavenge ${ }^{60} \mathrm{Co}$ with $\mathrm{Na}_{2} \mathrm{~S}$. The scavenged waste was then routed to another tank for settling, sampling, and decantation to a crib. The settling tanks for this "In Farm scavenged" waste were 241-C-108, $241-C-109,241-C-111$, and 241-C-112.

The In Farm precipitate comprises 20 to 25 percent of the total ferrocyanide material in the Hanford Site tank farms. This material is expected to possess a much higher ferrocyanide concentration content than the more prevalent (70 percent of the total ferrocyanide material) U Plant material. Analytes that differentiate ferrocyanide waste from other wastes are nickel, calcium, and ${ }^{137} \mathrm{Cs}$. Over time, additional gravity settling may have compressed the waste layers, increasing the concentration of some of these analytes. However, the effect of radiation and high $\mathrm{pH}$ conditions from later waste additions on the waste matrix is largely unknown. 
Figure 2-2. In Farm Flowsheet.

\section{Ferrocyanide Production by "In-Farm" Flowsheet}

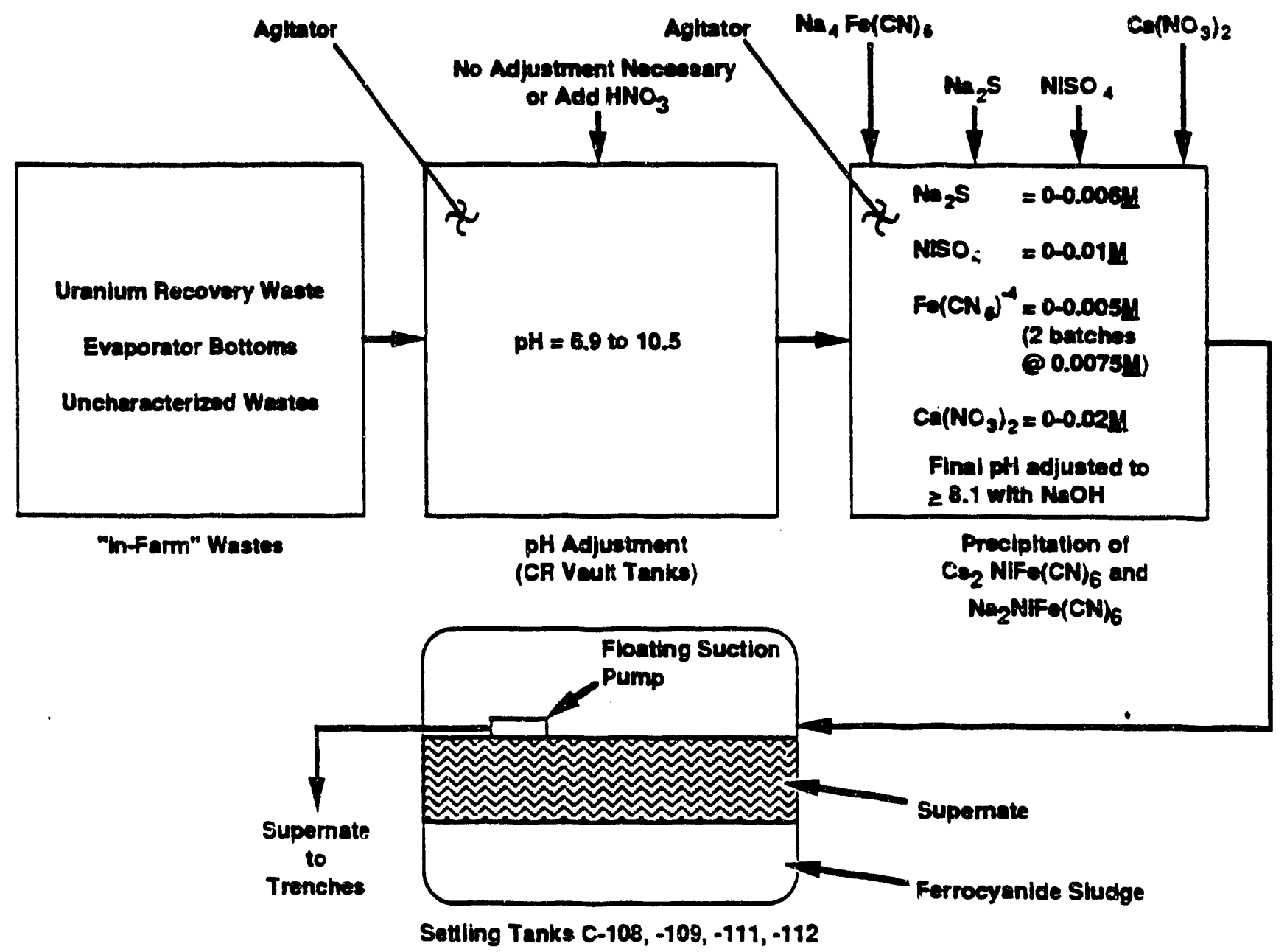


Exposure of the waste to these conditions is believed to have degraded the ferrocyanide. However, laboratory results confirming that hypothes is are still pending (Lilga et al. 1992; Babad et al. 1993).

The first transfer of scavenged waste for settling was in the fourth quarter of 1955. In Farm scavenging was completed in December 1957 (General Electric 1958). The inventory of solids in tank $241-C-112$ at the end of the ferrocyanide-scavenging program, as calculated by the Borsheim-Simpson (1991) model, was $318,000 \mathrm{~L}(84,000 \mathrm{gal})$ with essentially no free supernate. The scavenging record (General Electric 1958) gives the tank level as $0.67 \mathrm{~m}$ (2 ft $2.5 \mathrm{in.})(323,000 \mathrm{~L}[85,400 \mathrm{gal}])$. A History of the 200 Area Tank Farms (Anderson 1990) reports a total volume of $318,000 \mathrm{~L}(84,000 \mathrm{gal})$, but lists only $174,000 \mathrm{~L}(46,000 \mathrm{gal})$ of that inventory as solids.

After the end of scavenging in late 1957, tank 241-C-112 remained in active service. However, the tank had relatively limited activity from 1958 to the end of its service life in 1980. The volume is shown as increasing by $189,000 \mathrm{~L}(50,000 \mathrm{gal})$ of liquid to approximately $507,000 \mathrm{~L}(134,000 \mathrm{gal})$ in the fourth quarter of 1958, but no incoming or outgoing transfers were noted. In the third and fourth quarters of 1960 , a total of $996,000 \mathrm{~L}(263,000 \mathrm{gal})$ of highly alkaline cladding waste (a waste known to contain substantial amounts of solids) was added to the tank, but the reported solids inventory $(174,000 \mathrm{~L}[46,000 \mathrm{gal}])$ did not change (Anderson 1990). Cladding waste solids would have settled on top of the ferrocyanide sludge already present.

Several small transfers with relatively high concentrations of ${ }^{90} \mathrm{Sr}$ occurred after 1958. Waste from the strontium semiworks/hot semiworks was added to the tank with the total volume 1 isted as $2.07 \mathrm{M} \mathrm{L}(547,000 \mathrm{gal})$ at the end of 1964 (the reported solids inventory was still only 174,000 L $[46,000 \mathrm{gal}])$. The listed volumes for the first quarter report in 1965 are a total volume of $2.04 \mathrm{ML}(538,000 \mathrm{gal})$, with a solids volume of $485,000 \mathrm{~L}$ (128,000 gal) (Anderson 1990). This solids level measurement was apparently the first since additional waste was added to the tank following the last scavenging pumpout in 1958.

The reported waste volume remained essentially unchanged (between 2.01 and $2.04 \mathrm{ML}[532,000$ and 538,000 gal $]$ ) until a transfer of $1.29 \mathrm{ML}$ (340,000 gal) to tank 241-C-104 in the first quarter of 1970. This transfer left a heel of at least $727,000 \mathrm{~L}(192,000 \mathrm{gal})$. A floating suction pump transfer would not have transferred any solids because the maximum reported solids level was $485,000 \mathrm{~L}(128,000 \mathrm{gal})$. In early 1970 , some B Plant ionexchange waste (1.24 M L [327,000 gal]) from tank $241-C-110$ and drainage to the $C-301$ catch tank $(79,000 \mathrm{~L}[21,000 \mathrm{gal}])$ ) was added to tank 241-C-112. Between 1970 and 1975 , the reported solids volume ranged between 454,000 and $522,000 \mathrm{~L}(120,000$ and $138,000 \mathrm{gal})$, and the total volume reported decreased from $2.06 \mathrm{ML}$ to $2.01 \mathrm{ML}(543,000$ to $532,000 \mathrm{gal})$ (Anderson 1990).

Tank 241-C-112 was suspected of leaking and was emptied of pumpable 1 iquid to tank 241-C-103 in 1975-1976 (Anderson 1990); later surveillance never confirmed the suspected leak. Some solids may have been transferred, as the reported tank solids volume decreased from $485,000 \mathrm{~L}(128,000 \mathrm{gal})$ to 413,000 L (109,000 gal). However, the solids transferred would have been those that settled on top of the ferrocyanide solids (i.e., cladding waste solids). The previously calculated volume of ferrocyanide sludge 
was $318,000 \mathrm{~L}(84,000 \mathrm{gal})$, with reported volumes ranging between 174,000 and $323,000 \mathrm{~L}(46,000$ and $85,400 \mathrm{gal})$. Sludge volume in the tank may have decreased between 1958 and 1975 with further settling and compaction from the weight of overlying solids. However, the volume of the ferrocyanide sludge yould not have increased during that time frame. There was no mixing equipment in tank 241-C-112 to move the settled ferrocyanide solids into the overlying solids layer. Therefore, it was concluded that no appreciable volume of ferrocyanide solids were transferred to tank 24l-C-103 (Borsheim and Simpson 1991).

The last major waste type was aluminum cladding waste. These materials would be high in aluminum and silica, with a very high $\mathrm{pH}$. However, the solids volume contribution to the tank is unknown because the majority of the solids would be deposited in the first tank to receive the wastes, which was not tank 241-C-112. The high $\mathrm{pH}$ of this waste is considered a significant factor affecting the state of the waste matrix. Other wastes had discernable impacts on the bulk characteristics of the tank contents as well. The strontium semiworks waste had a small volume of waste added, but would have a very high ${ }^{90} \mathrm{Sr}$ conlent because it included strontium recovery and purification waste losses. Tine B Plant ion-exchange waste was primar'ly liquid and was not expected to contribute significantly to the solids in the tank.

\subsubsection{Unreviewed Safety Question Declaration}

Efforts have been underway since the mid-1980's to evaluate the potential of a ferrocyanide decomposition reaction in Hanford Site SSTs (Burger 1989; Burger and Scheele 1990; Burger 1984). In 1987, the Final Environmental Impact Statement, Disposal of Hanford Defense High Level, Transuranic and Tank Wastes, hereinafter referred to as the HDW-EIS (DOE 1987), was issued. In the HDW-EiS, it was projected that the bounding "worst-case" accident in a ferrocyanide tank would be an explosion resulting in a subsequent short-term radiation dose to the public of $200 \mathrm{mrem}$.

A later General Accounting Office (GAO) study (Peach 1990) postulated greater "worst-case" accident consequences, with independently calculated doses one to two orders of magnitude greater than the HDW-EIS. A special Hanford Site 5errocyanide Task Team was commissioned in September 1990 to address all issues involving the ferrocyanide tanks, including the consequences of a potential accident. On October 9, 1990, the Secretary of Energy announced that a supplemental environmental impact statement would be prepared containing an updated analysis of safety issues for the Hanford Site SSTs, inciuding a hypothetical ferrocyanide explosion. In October 1990, the ferrocyanide issue was also declared an USQ because the consequences of the accident scenario (as calculated by the GAO) were outside the bounds of the current safety analyses for SSTs. Furthermore, additional monitoring of tanks with designated USQs was mandated by Public Law 101-510 (1990).

Using a computer model output (Jungfleisch 1984), process knowledge, and transfer records, 24 waste tanks have been identified at the Hanford Site as potentially containing $1,000 \mathrm{~g}$-mol (465 lb) or more of ferrocyanide as the $\mathrm{Fe}(\mathrm{CN})_{6}{ }^{-4}$ ion. On further investigation, six tanks are believed to have received less than 1,000 g-mol of ferrocyanide sludge and are therefore 
candidates for removal from the Watch List (Cash 1993). Tank 241-C-112 is on the Ferrocyanide Watch List because it was a known process tank during the ferrocyanide-scavenging campaigns.

\subsection{EXPECTED TANK CONTENTS/CONDITIONS}

Process knowledge obtained from historical records and waste simulants produced from the scavenging process flowsheets can be used to predict the major constituents and some general physical properties of the waste matrix in the waste tanks. Initially, the differences between the $U$ Plant and In Farm ferrocyanide sludges were not fully appreciated. However, further investigation of the simulants showed that the In Farm process would be expected to precipitate approximately 1.0 to 1.3 vol\% solids, and thus the sludge would have been deposited in the receiver tanks in layers approximately 3.6 to $6.1 \mathrm{~cm}$ (1.4 to 2.4 in.) thick. This is much less than the 4.25 vol\% and 15- to 20-cm (6- to 8-in.) layers expected from the $U$ Plant material. The In Farm scavenged ferrocyanide tanks (such as tank 241-C-112) are expected to contain relatively soft sludge, which can be push-mode sampled. This expectation was supported by inspection of in-tank photographs. The other waste solids that were added to the tank after the scavenging campaign are also expected to be soft. During its operating history, tank 241-C-112 was never subject to any of the various in-tank solidification processes; consequently, there was no formation of hard salt cake on top of the sludge (as there was in the BY Tank Farm).

The most recent waste inventory measurement for tank $241-C-112$ reports $394,000 \mathrm{~L}(104,000 \mathrm{gal})$ of waste with an estimated $121,000 \mathrm{~L}(-32,000 \mathrm{gal})$ of drainable liquids (Hanion 1992). These figures translate to a waste depth of $115.1 \mathrm{~cm}$ (45.3 in.) at the tank centerline. Because the tank had less than 189,000 L $(50,000$ gal) of drainable liquid, it was administratively interim-stabilized in September 1990, and is considered sound. Tank Farm Operations has installed a second thermocouple tree in tank 241-C-112, and the readings between the two thermocouple trees on opposite sides of the tank are consistent. The present maximum waste temperature in tank $241-\mathrm{C}-112$ is $\sim 29{ }^{\circ} \mathrm{C}$ $\left(85^{\circ} \mathrm{F}\right)$, and the estimated heat load in the tank is less than $2.93 \mathrm{~kW}$ $(10,000 \mathrm{Btu} / \mathrm{hr})$. Tank $241-\mathrm{C}-112$ is considered to have one of the highest ferrocyanide concentrations of all the ferrocyanide Watch List SSTS (Borsheim and Simpson 1991).

In summary, various nickel ferrocyanide complexes (primarily disodium) are expected to be mixed with an interstitial solution containing sodium nitrate and nitrite. Cesium-137 is expected to be present as a mixed salt (possibly as $\mathrm{NaCsNiFe}(\mathrm{CN})_{6}$ ); strontium-90 may be in several potential compounds: phosphate, sulfate, or carbonate. Both of these radionuclides have decayed through slightly more than one half-life, and therefore are not as abundant as when the scavenging waste was originally deposited. Other fission products with relatively short half-lives (such as ${ }^{60} \mathrm{Co}$ and ${ }^{106} \mathrm{Ru}$ ) are not expected to be in abundance, especially with the limited number of waste additions for this tank. Hydrated transition metal oxides/hydroxides (including small amounts of transuranics) are also expected due to alkaline conditions. Other ions expected to be present are potassium, calcium, aluminum, and uranium. The supernate and interstitial liquid is expected to contain large amounts of sodium, nitrate, and nitrite ions. 


\subsection{ANALYTICAL RESULTS FROM SIMULANT STUDIES}

Physical and chemical measurements performed on simulants of ferrocyanide tank waste provide additional information and perspective regarding the condition and properties of the waste in tank 241-C-112.

\subsubsection{Simulant Formulation: In Farm 2 Flowsheet Material}

The In Farm 2 flowsheet material is considered to be an energetically conservative but reasonably close physical and chemical analogue of the ferrocyanide precipitate in tank 241-c-112 as it was deposited in the tank during the scavenging campaign. The In Farm 2 flowsheet materials were prepared according to the following instructions (Jeppson and Wong 1993). The feed solution composition is listed in Table 2-1. Deionized water was used for feed solution and chemical addition makeup.

Table 2-1. Feed Solution Composition for In Farm 2 Flowsheet.

\begin{tabular}{|l|c|}
\hline \multicolumn{1}{|c|}{ Component } & $\begin{array}{c}\text { Concentration } \\
(\mathrm{mol} / \mathrm{L})\end{array}$ \\
\hline Sodium Nitrate $\left(\mathrm{NaNO}_{3}\right)$ & $3.75 \underline{\mathrm{M}}$ \\
\hline Cesium Nitrate $\left(\mathrm{CsNO}_{3}\right)$ & $0.00025 \mathrm{M}$ \\
\hline Sodium Nitrite $\left(\mathrm{NaNO}_{2}\right)$ & $1.25 \underline{\mathrm{M}}$ \\
\hline Sodium Sulfate $\left(\mathrm{Na}_{2} \mathrm{SO}_{4}\right)$ & $0.17 \underline{\mathrm{M}}$ \\
\hline Sodium Phosphate $\left(\mathrm{Na}_{3} \mathrm{PO}_{4}\right)$ & $0.16 \underline{\mathrm{M}}$ \\
\hline
\end{tabular}

The product sludge was the precipitate produced when performing the following steps for each liter of feed solution. This procedure mimicked the actual In Farm 2 process that is illustrated in Figure 2-2. The feed solution was heated to $40{ }^{\circ} \mathrm{C}$ and the $\mathrm{pH}$ adjusted to $9.1 \pm 0.5$. The sodium ferrocyanide was then added to the solution, followed by nickel sulfate. The simulant solution was agitated for 1 hour, then struck with calcium nitrate. After the addition of calcium nitrate, the solution was agitated for another hour and allowed to settle. The settling was done for eight days and the supernate was decanted. The remaining sludge was centrifuged at $2,100 \mathrm{~g}$ for 14 hours and $1,820 \mathrm{~g}$ for 7 days in an attempt to simulate 3.6 and 30 gravity-years of settling respectively (Jeppson and Wong 1993). Selected physical properties for the two settled sludges are presented in Table 2-2. Table 2-3 presents an estimate of the chemical composition of the In Farm 2 simulant. 


\subsubsection{Physical Charicteristics (see Jeppson and Wong 1993)}

Table 2-2. Summary of In Farm 2 Characterization Data.

\begin{tabular}{|c|c|c|}
\hline \multirow{4}{*}{$30 \mathrm{~g}-\mathrm{yr}$} & Property & In Farm 2 sludge \\
\hline & Water content, sludge & 51 wt $\%$ \\
\hline & $\mathrm{pH}$, supernatant & 9.42 \\
\hline & Bulk density, sludge & $1.39 \mathrm{~g} / \mathrm{mL}$ \\
\hline \multirow{7}{*}{$3.6 \mathrm{~g}-y \mathrm{r}$} & Bulk density, supernate & $1.27 \mathrm{~g} / \mathrm{mL}$ \\
\hline & Particle density (dried sludge) & $2.38 \mathrm{~g} / \mathrm{mL}$ \\
\hline & $\begin{array}{l}\text { Particle size distribution, } \\
\text { (by number) }\end{array}$ & $\begin{array}{l}97 \%<2 \mu m \\
\text { median diameter**: } \\
\text { Acquisition Range: }\end{array}$ \\
\hline & $\begin{array}{l}\text { Particle size distribution, } \\
\text { (by volume) }\end{array}$ & $\begin{array}{l}100 \%<110 \mu \mathrm{m} \\
\text { median diameter } \star *: \\
\text { Acquisition range: } \quad 0.5-15,16.8 \mu \mathrm{m} \\
\end{array}$ \\
\hline & $\begin{array}{l}\text { Hydraulic conductivity } \\
\text { (permeability) }\end{array}$ & $4.0 \times 10^{-7} \mathrm{~cm} / \mathrm{s}$ \\
\hline & Total porosity & $67.9 \%$ \\
\hline & Thermal conductivity & 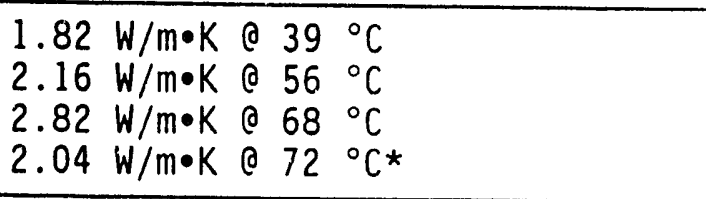 \\
\hline
\end{tabular}

* Jeppson and Wong (1993) noted an anomolous data point, but were unable to explain the inconsistency of the observation.

**Two separate measurements. 


\subsubsection{Chemical Composition (see Jeppson and Wong 1993)}

Table 2-3. Estimated Composition of Homogenized, Centrifuged, Ferrocyanide Sludge Simulant.

\begin{tabular}{|l|c|}
\hline \multicolumn{1}{|c|}{ Sludge component } & $\begin{array}{c}\text { Average In Farm 2 } \\
\text { weight fraction }\end{array}$ \\
\hline Disodium mononickel ferrocyanide: $\mathrm{Na}_{2} \mathrm{NiFe}(\mathrm{CN})_{6}$ & 0.101 \\
\hline Sodium nitrate: $\mathrm{NaNO}_{3}$ & 0.174 \\
\hline Sodium nitrite: $\mathrm{NaNO}_{2}$ & 0.051 \\
\hline Sodium hydrogen phosphate: $\mathrm{Na}_{2} \mathrm{HPO}_{4}$ & 0.016 \\
\hline Sodium sulfate: $\mathrm{Na}_{2} \mathrm{SO}_{4}$ & 0.015 \\
\hline Calcium phosphate: $\mathrm{Ca}_{3}\left(\mathrm{PO}_{4}\right)_{2}$ & 0.073 \\
\hline Water & 0.51 \\
\hline Percent mass balance subtotal & 94.0 \\
\hline $\left.\begin{array}{l}\text { Percent unknown-- } 1 \text { ikely includes } \mathrm{Fe} \\
\text { Ni(OH) }\end{array}\right)_{2}$ and other materials from trace impurities & 6.0 \\
\hline
\end{tabular}

\subsubsection{Energetics Behavior of Ferrocyanide Sludge Simulant}

Available chemical process information indicates that there were three significantly different types of ferrocyanide waste (Sloat 1954; Schmidt and Stedwell 1954). Nonradioactive waste simulants have been developed and tested using this information. In Farm ferrocyanide waste, accounting for 20 to 25 percent of the total ferrocyanide waste, was formed from treatment of waste that was already stored in the tanks. The waste in tank $241-c-112$ was produced using the In Farm process. Most of this waste had less inert solids in the waste stream; therefore, it is believed to have been more concentrated in ferrocyanide than other ferrocyanide wastes. In Farm simulants exhibit propagating exothermic activity when examined by differential and adiabatic scanning calorimetry (DSC and ASC).

Estimates of tank waste reactivity, developed after the ferrocyanide USQ was declared, were based on thermodynamic estimates (Colby and Crippen 1991). Several chemical reaction pathways were evaluated and heats of reaction were determined for each possible reaction from the published heats of formation of the reactants and the products. For the purpose of developing these estimates, the condition of the reactants are dry solid reagents at standard temperature and pressure in a stoichiometric ratio. The theoretical heats of reaction ranged in value from $\Delta H=-9.6 \mathrm{~kJ} / \mathrm{g}$ to $\Delta H=+19.7 \mathrm{~kJ} / \mathrm{g}$ of $\mathrm{Na}_{2} \mathrm{NiFe}(\mathrm{CN})_{6}$, and are listed below with their corresponding chemical reactions.
(1) $\mathrm{Na}_{2} \mathrm{NiFe}(\mathrm{CN})_{6}+54 \mathrm{NaNO}_{3}+22 \mathrm{H}_{2} \mathrm{O}--->6 \mathrm{Na}_{2} \mathrm{CO}_{3}+\mathrm{FeO}+\mathrm{NiO}+60 \mathrm{NO}_{2}+44 \mathrm{NaOH}$ $\Delta \mathrm{H}^{\mathrm{S}}=+19.7 \mathrm{~kJ} / \mathrm{g}$ of $\mathrm{Na}_{2} \mathrm{NiFe}(\mathrm{CN})_{6}$
(2) $\mathrm{Na}_{2} \mathrm{NiFe}(\mathrm{CN})_{6}+14 \mathrm{NaNO}_{3}+2 \mathrm{H}_{2} \mathrm{O}--->6 \mathrm{Na}_{2} \mathrm{CO}_{3}+\mathrm{FeO}+\mathrm{NiO}+2 \mathrm{ONO}+4 \mathrm{NaOH}$ $\Delta \mathrm{H}=-0.7 \mathrm{~kJ} / \mathrm{g}$ of $\mathrm{Na}_{2} \mathrm{NiFe}(\mathrm{CN})_{6}$


(3) $\mathrm{Na}_{2} \mathrm{NiFe}(\mathrm{CN})_{6}+9 \mathrm{NaNO}_{3}$

(4) $\mathrm{Na}_{2} \mathrm{NiFe}(\mathrm{CN})_{6}+10 \mathrm{NaNO}_{3}$

(5) $\mathrm{Na}_{2} \mathrm{NiFe}(\mathrm{CN})_{6}+9 \mathrm{NaNO}_{3}$

$$
\begin{aligned}
& --->5.5 \mathrm{Na}_{2} \mathrm{CO}_{3}+\mathrm{FeO}+\mathrm{NiO}+7.5 \mathrm{~N}_{2} \mathrm{O}+0.5 \mathrm{CO}_{2} \\
& \Delta \mathrm{H}=-6.8 \mathrm{~kJ} / \mathrm{g} \text { of } \mathrm{Na}_{2} \mathrm{NiFe}(\mathrm{CN})_{6} \\
& 6 \mathrm{Na}_{2} \mathrm{CO}_{3}+\mathrm{FeO}+\mathrm{NiO}+6 \mathrm{~N}_{2} \mathrm{O}+4 \mathrm{NO}^{2} \\
& \Delta \mathrm{H}^{2}=-5.7 \mathrm{~kJ} / \mathrm{g} \text { of } \mathrm{Na}_{2} \mathrm{NiFe}(\mathrm{CN})_{6} \\
& ---\rightarrow 4 \mathrm{Na}_{2} \mathrm{CO}_{3}+\mathrm{FeO}+\mathrm{NiO}+6 \mathrm{~N}_{2}+2 \mathrm{CO}_{2} \\
& \Delta \mathrm{H}^{2}=-9.6 \mathrm{~kJ} / \mathrm{g} \text { of } \mathrm{Na}_{2} \mathrm{NiFe}(\mathrm{CN})_{6}
\end{aligned}
$$

At temperatures below $1700^{\circ} \mathrm{C}\left(3100^{\circ} \mathrm{F}\right)$, the carbonate product is thermodynamically favorable and should predominate (Scheele et al. 1991). Note that considerably lower energy releases are obtained if the reaction is incomplete or if $\mathrm{NO}$ or $\mathrm{NO}_{2}$ is formed rather than $\mathrm{N}_{2}$ or $\mathrm{N}_{2} \mathrm{O}$. A three-component diagram illustrating the exothermic potential of various mixtures of ferrocyanide, nitrate, and inerts is presented in Figure 2-3. Further detail regarding the thermodynamic estimates of these mixtures is presented in colby and Crippen (1991).

Waste simulants were prepared using the In Farm and $U \mathrm{Plant}$ process flowsheets and were tested for chemical activity. Chemical and physical analyses of the In Farm and U Plant waste simulants show that they contain an average of 51 and $66 \mathrm{wt} \%$ water, respectively, after centrifugation. The centrifugation was done to represent 30 gravity-years of compaction that may have occurred during storage. This amount of water in the waste matrix presents a tremendous heat sink that must be overcome before any reactions can become self-sustaining. During the DSC examinations, the samples exhibited large endotherms between room temperature and $150{ }^{\circ} \mathrm{C}$ (Jeppson and Wong 1993). Results from thermogravimetric analyses being run at the same time showed a large loss of mass (i.e., evaporation of water) in this same temperature range; thus, reactions were only able to occur in dry or nearly dry sample material. Average ferrocyanide content of the In Farm 2 waste simulants is approximately 10.1 wet $w t \%(20.6 \mathrm{wt} \%$ dry $)$. Table $2-4$ presents the $\Delta H$ found for some simulant materials.

Table 2-4. Heats of Reaction of Various Simulants.

\begin{tabular}{|l|l|c|c|}
\hline \multicolumn{1}{|c|}{ Material } & \multicolumn{1}{|c|}{$\begin{array}{c}\Delta H \\
\text { (From Adiabatic } \\
\text { Calorimetry) }\end{array}$} & $\begin{array}{c}\text { Wt\% Ferrocyanide } \\
\text { (dry) } \\
{\left[\mathrm{Na}_{2} \mathrm{NiFe}(\mathrm{CN})_{6}\right]}\end{array}$ & $\begin{array}{c}\text { Calculated } \Delta H \\
\text { per gram } \\
\mathrm{Na}_{2} \mathrm{NiFe}(\mathrm{CN})_{6}\end{array}$ \\
\hline U Plant 1 simulant & $\begin{array}{l}-0.17 \mathrm{~kJ} / \mathrm{g} \text { of dry } \\
\text { material }\end{array}$ & 4.3 & $-3.95 \mathrm{~kJ} / \mathrm{g}$ \\
\hline $\begin{array}{l}U \text { Plant 2 simulant } \\
\text { (Bottom fraction) }\end{array}$ & $\begin{array}{l}-0.34 \mathrm{~kJ} / \mathrm{g} \text { of dry } \\
\text { material }\end{array}$ & 8.6 & $-3.95 \mathrm{~kJ} / \mathrm{g}$ \\
\hline $\begin{array}{l}\text { In Farm 1 simulant } \\
\text { (Bottom Fraction) }\end{array}$ & $\begin{array}{l}-1.20 \mathrm{~kJ} / \mathrm{g} \text { of dry } \\
\text { material }\end{array}$ & 25.5 & $-4.71 \mathrm{~kJ} / \mathrm{g}$ \\
\hline
\end{tabular}

The onset temperatures for propagating reactions to take place in the simulants range from $244{ }^{\circ} \mathrm{C}$ to $278{ }^{\circ} \mathrm{C}\left(471\right.$ to $\left.532{ }^{\circ} \mathrm{F}\right)$. However, Arrhenius-type reactions may occur at lower temperatures (Fauske 1992). NOTE: $4.18 \mathrm{~J}=1 \mathrm{cal}$. 
Figure 2-3. Ferrocyanide Tank 3-Component Diagram.

\section{FERROCYANIDE TANK 3-COMPONENT DIAGRAM}

REACTION PROPAGATION VS. CONCENTRATION

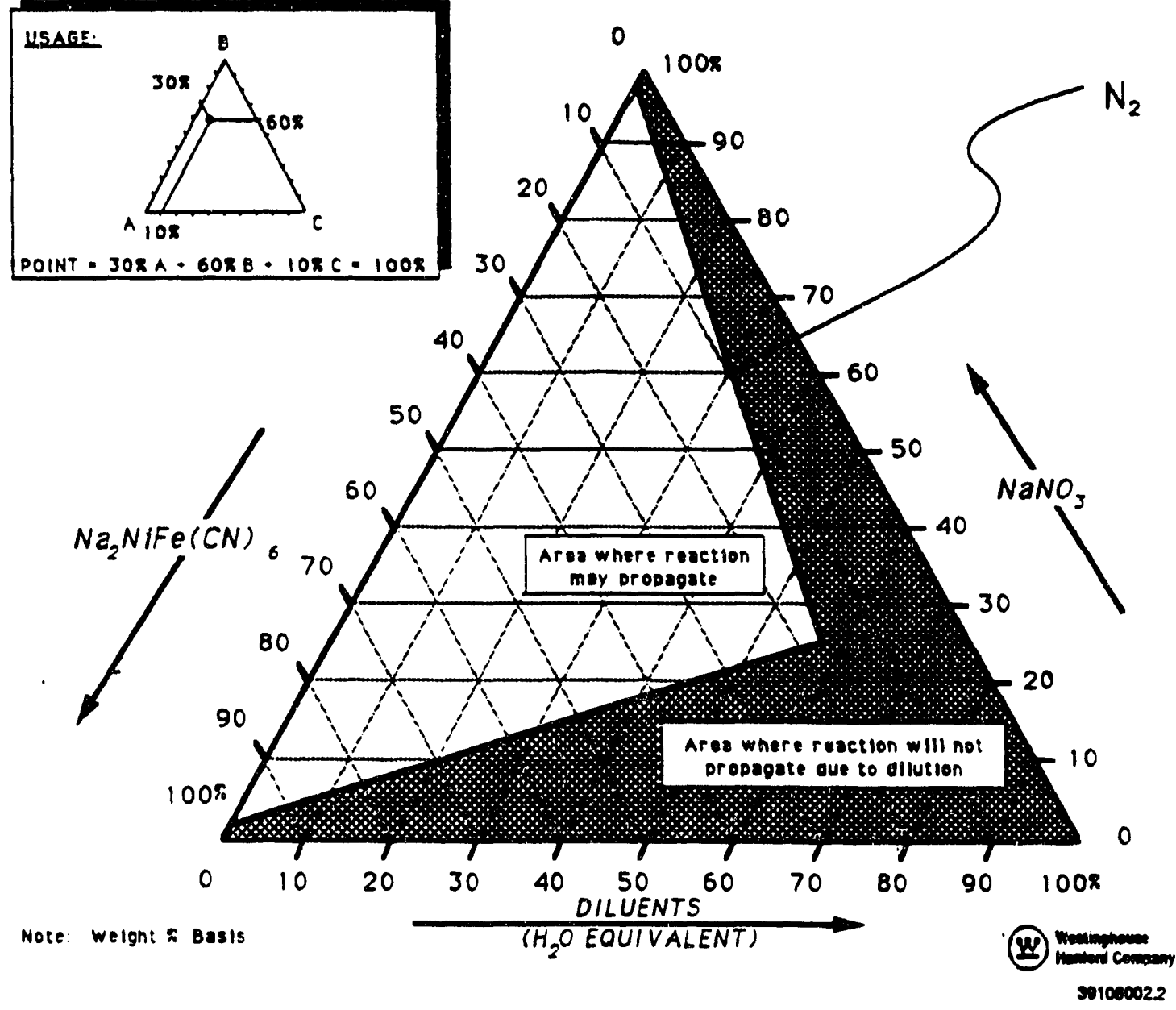




\subsection{CORE SAMPLING}

\subsection{DESCRIPTION OF SAMPLING EVENT}

Tank 241-C-112 was push-mode core sampled through three risers during a period from March 19, 1992, to March 26, 1992. Two segments were expected from each core sample. Core 34 was obtained from riser \#2 on March 19, 1992 , to March 22, 1992. Core 35 was obtained from riser \#7 on March 22, 1992, and March 23, 1992. Core 36 was obtained from riser \#8 on March 24, 1992, to March 26, 1992. The core samples from tank 241-C-112 were obtained using a specially designed core sampling truck (CST). The sampling equipment is mounted on a rotating platform on the CST. Access to the interior of the tank is provided by various tank risers. These risers are pipes of various diameters leading into the tank dome from the ground. The riser configuration for tank 241-C-112 is given in Figure 3-1. A review of the tank farm operating records and a field inspection of the tank risers determine which risers can be used in the sampling operation. A riser is opened and the CST is positioned over the riser. The sampler is lowered into the tank through the drill string and pushed into the waste.

The sampler is constructed of stainless steel and is $48 \mathrm{~cm}$ (19 in.) long, with a 2.2-cm (7/8-in.) inside diameter, and has a volume of $187 \mathrm{~mL}$ $(0.05 \mathrm{gal})$. Tank Farm Operations has determined that sampling events of one or two segments do not require hydrostatic head balance fluid. Therefore, none was used in this operation, eliminating any potential problems with sample contamination. When a segment is captured by the sampler, it is sealed within a stainless steel liner, and the liner is placed within a shipping cask. The shipping casks are approximately $122 \mathrm{~cm}$ tall, $13 \mathrm{~cm}$ in diameter, and have $2.5 \mathrm{~cm}$ of lead shielding. This degree of shielding and containment protects workers from excessive radiological exposure and prevents any liquids from the sample (or the sample itself) from being lost.

The casks were transported to the 324 Shielded Materials Facility for gamma scanning, and then to the 325 Analytical Chemistry Laboratory for characterization analysis. Both facilities are operated by Battelle-Pacific Northwest Laboratory in the 300 Area of the Hanford Site. Cores 34 and 35 arrived at the 324 Facility on March 25, 1992, and Core 36 arrived on March 26, 1992.

\subsection{CHAIN OF CUSTODY}

A chain-of-custody record was kept during the sampling event for each segment that was sampled. The chain-of-custody form is a one-page record that is used to ensure that (1) the sample is safely and properly transported from the field to the laboratory, and (2) the correct personnel are involved in the sampling operation and transportation of the sample to the laboratory.

One of the primary functions of the chain-of-custody record is to provide radiation survey data. This is a record of the radiation dose that is emitted from the shipping cask. The dose rates in mrem/hour are measured from the top, sides, and bottom of the cask. These values are recorded on the 
Figure 3-1. Tank 241-C-112 Riser Configuration.

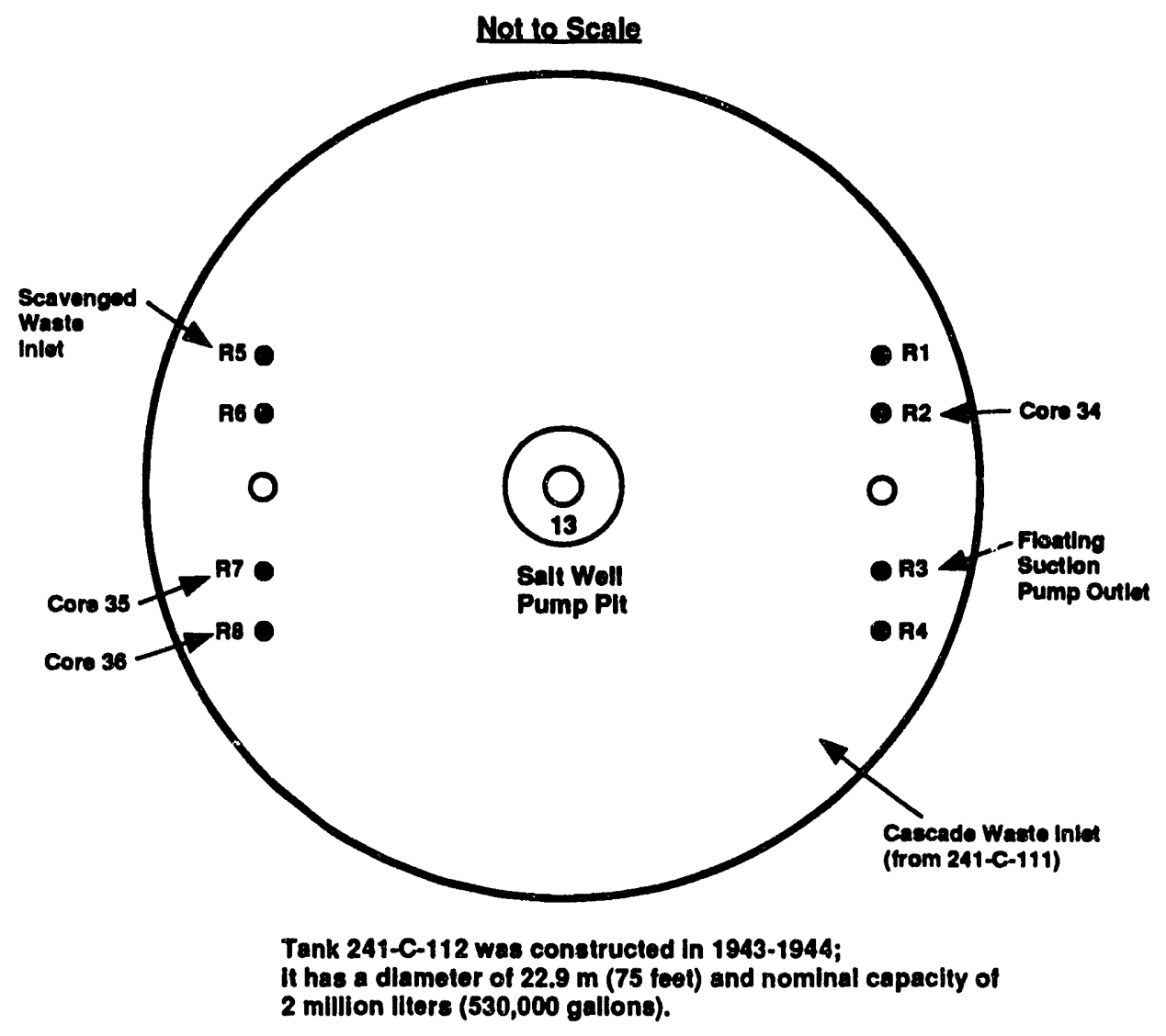

29304019.6 
chain of custody and represent the radiation being emitted directly from the sample. The last item recorded under the radiation survey data is the smearable contamination. Smearable contamination represents the radiation from waste material that is not sealed within the shipping cask; values greater than $100 \mathrm{mrem} /$ hour are considered unsafe. Measurements are made both in the field and in the laboratory. No smearable contamination was found with these samples.

The chain of custody has several other important functions: (1) to provide a modest description of the cask, sampler, and the expected contents of the sampler (shipment, sample, and cask serial numbers for the specific sampling event); (2) to provide summary information about the analytical suite that the sample will undergo or reference the salient documentation; (3) to provide traceability for the sample during transport; and (4) to ensure sample integrity on arrival at the laboratory. This information is provided to ensure that each sample can be uniquely identified.

Copies of the chain-of-custody forms are available in the full data package on file at the Hanford Analytical Services Management (HASM) office. From inspection of the chain-of-custody records, there appear to be no irregularities in the sampling or transport of tank 241-C-112 samples from the field that would merit a safety or sample integrity concern (i.e., sample containment was not breached). 
This page intentionally left blank. 


\subsection{SAMPLE PREPARATION/SAMPLE EXTRUSION}

\subsection{DESCRIPTION OF GAMMA SCANNING EFFORT}

The 324 Shielded Materials Facility has a device that was used for radionuclide measurements of irradiated fuel rods for the Fast Flux Test Facility program. The fuel pin reader was idle and there was the belief that this effort could be an efficient and innovative utilization of available resources in the Tank Waste Characterization/Waste Tank Safety Programs. Cores 34, 35, and 36 were transferred to the Shielded Materials Facility, and gamma scanning was performed on tank $241-\mathrm{C}-112$ sample segments using this
device. Nine isotopes were scanned for: ${ }^{137} \mathrm{Cs},{ }_{155} \mathrm{Eu},{ }^{154} \mathrm{Eu},{ }^{24} \mathrm{Am},{ }^{144} \mathrm{Ce},{ }^{134} \mathrm{Cs}$, device ${ }^{60} \mathrm{Co},{ }^{106} \mathrm{Ru}$, and ${ }^{153} \mathrm{Gd}$. Of these, only the ${ }^{137} \mathrm{Cs}$, isotope had sufficient activity to be considered valid. The gamma scanning effort was undertaken as a means to obtain core sample information prior to extrusion. The data presented in Figures 4-1, 4-2, and 4-3 have been smoothed in a 5-point rolling average, to eliminate any anomalous peaks and to aid in interpretation of the scan.

\section{1 .1 Core 34}

Core 34 was scanned in 2.5-mm (0.1-in.) increments at 500 seconds per increment on April 4, 1992. The scan was performed with the core in a vertical orientation, and the scan was begun at an axial location below the bottom of the segments (refer to Figure 4-1). Peak count rates for ${ }^{137} \mathrm{Cs}$ in Core 34 were 2.72 counts/sec $(1,361$ counts in 500 seconds). Sample lengths were estimated from the activity signatures to be $8.6 \mathrm{~cm}(3.4$ in.) for segment 92-001 and $36.3 \mathrm{~cm}(14.3 \mathrm{in.})$ for segment 92-002. These sample lengths were determined to be relatively reliable for the sample solids upon extrusion. However, there remained considerable uncertainty regarding sample recovery until the samples were extruded. In the case of segment 92-001, it appeared that suspended solids were concentrated at the bottom of the sampler while it was being scanned; thus, their activity signature masked the amount of cohesive solids in the sampler. After filtering, the liquids were found to have very little activity associated with them.

\section{1 .2 Core 35}

The scanning effort for Core 35 was subject to multiple mechanical difficulties. An anomalous peak was detected initially in the first scan on May 8,1992 . This result was suspicious and a rescan was recommended to confirm the result. The second scan performed on May 15 to verify this finding showed an abnormally low count rate (differing by an order of magnitude with Core 34 ). The peak from the first scan was attributed to a power surge and shutdown of the device; the low count rate from the second scan was determined to be a calibration error. A third scan was performed on May 22 with no problems (refer to Figure 4-2). Core 35 was scanned the first two times in 2.5-mm (0.1-in.) increments at 500 seco.ds per increment; the third scan was done at a resolution of $1.27 \mathrm{~mm}(0.05 \mathrm{in.})$ and 500 seconds per increment. The scan was performed with the core in a vertical orientation, and the scan was begun at an axial location below the bottom of the segments. 
Figure 4-1. 241-C-112 Gamma Scanning, Core 34 Results.

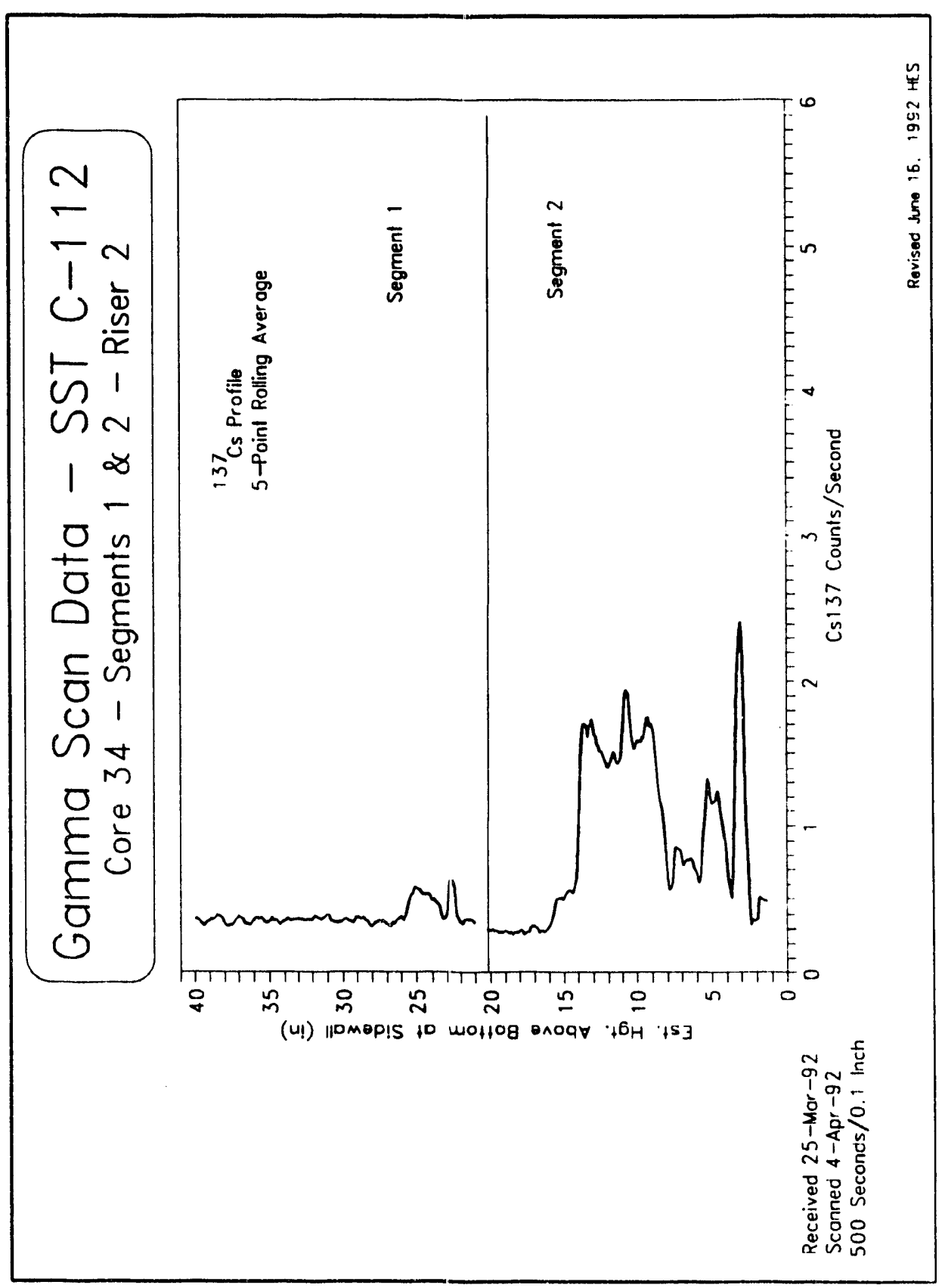


Figure 4-2. 241-C-112 Gamma Scanning, Core 35 Results.

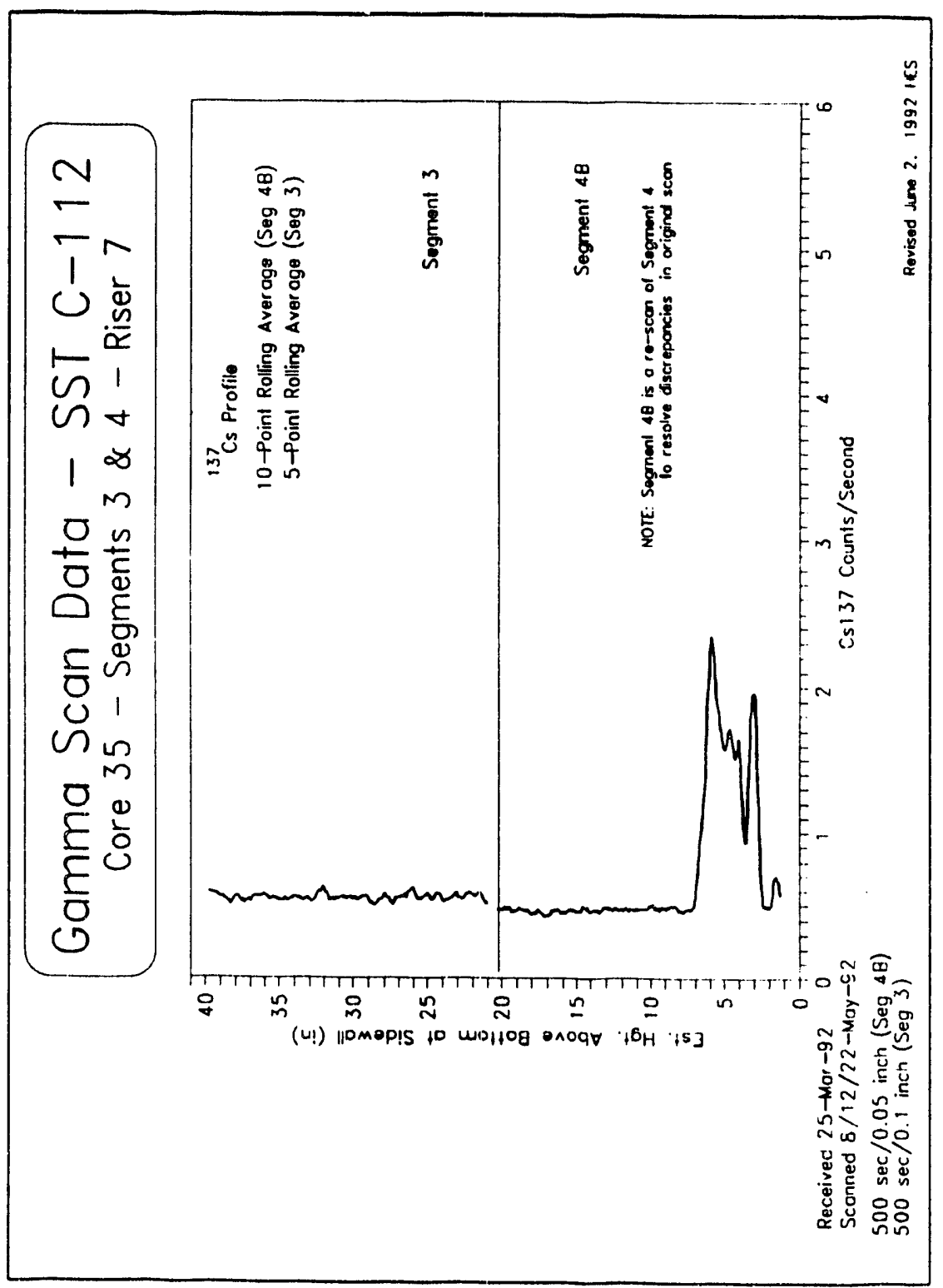


The sample valve was found open on segment 92-003 and the sampler was presumed empty; however, the sampler was scanned to determine if there was any contamination from contact with the tank contents. The gamma scanning measurements indicated no activity, and the sampler was empty upon extrusion. Peak count rates for ${ }^{137} \mathrm{Cs}$ in Core 35 , segment $92-004$ was 2.83 counts/second $(1,415$ counts in 500 seconds; comparable with Core 34$)$. Sample length was estimated to be $10.2 \mathrm{~cm}$ (4 in.) for segment 92-004. Sample length on extrusion was found to be approximately $7.6 \mathrm{~cm}$ ( 3 in.) and, as with core 34 , the liquids found had almost no activity.

\subsubsection{Core 36}

Core 36 was scanned in a slightly different manner than the other two. It was scanned in $2.5-\mathrm{mm}$ increments and 1,275 seconcis per increment on April $1: 1992$ (refer to Figure 4-3). This was done to determine if the longer iewing time improved the detection and resolution of the radioisotopes. There was no noticeable improvement in the sensitivity of the device using the longer counting times. Peak count rates for ${ }^{137} \mathrm{Cs}$ in Core 36 were 6.61 counts per second ( 8130 counts in 1,275 seconds). This core sample had a much higher overall activity than the other two, better sample recovery, and a much more distinctive signature. Sample lengths were estimated to be $22.9 \mathrm{~cm}$ ( 9 in.) for segment $92-005$ and $47 \mathrm{~cm}$ (18.5 in.) for segment 92-006. Sample length on extrusion was found to be approximately $21.8 \mathrm{~cm}(8.6 \mathrm{in}$.$) and$ $43.9 \mathrm{~cm}$ (17.3 in.), respectively. There were no liquids found with these segments.

\subsubsection{Tank 24i-C-112 Gamma Scanning Surmary}

Gamma scans were performed as a scoping procedure on Cores 34,35 , and 36 to obtain a qualitative measurement of the activity of the waste and to identify the major contributors. The gamma activity pattern obtained from the scans indicated some gross layering of the waste in the tank (i.e., differences in waste types) as well as differences in activity between individual batches. Of the nine isotopes scanned for, no significarit gamma emitters were found in the tank waste except ${ }^{137} \mathrm{Cs}$, al though the sample had a relatively high gamma background. The activity of tank 24l-C-112 waste material ranged between 0.15 and 2 R/hour, as measured through the drill string. No significant radiological activity was found in the drainable 1 iquid in the tank. The ${ }^{137} \mathrm{Cs}$ appeared to be almost entirely associated with the solids, and thus was assumed not soluble.

Each of the three cores in tank 241-C-112 was expected to contain one full segment and a partial (3/4) second segment. This expectation was based on calculations based on the inventory values given in Hanlon (1992). Results from the gamma scans indicated there was less than anticipated recovery. At that time, alteration of the analysis plan was necessary because there was not enough sample to perform all of the requested analyses. 
Figure 4-3. 241-C-112 Gamma Scanning, Core 36 Results.

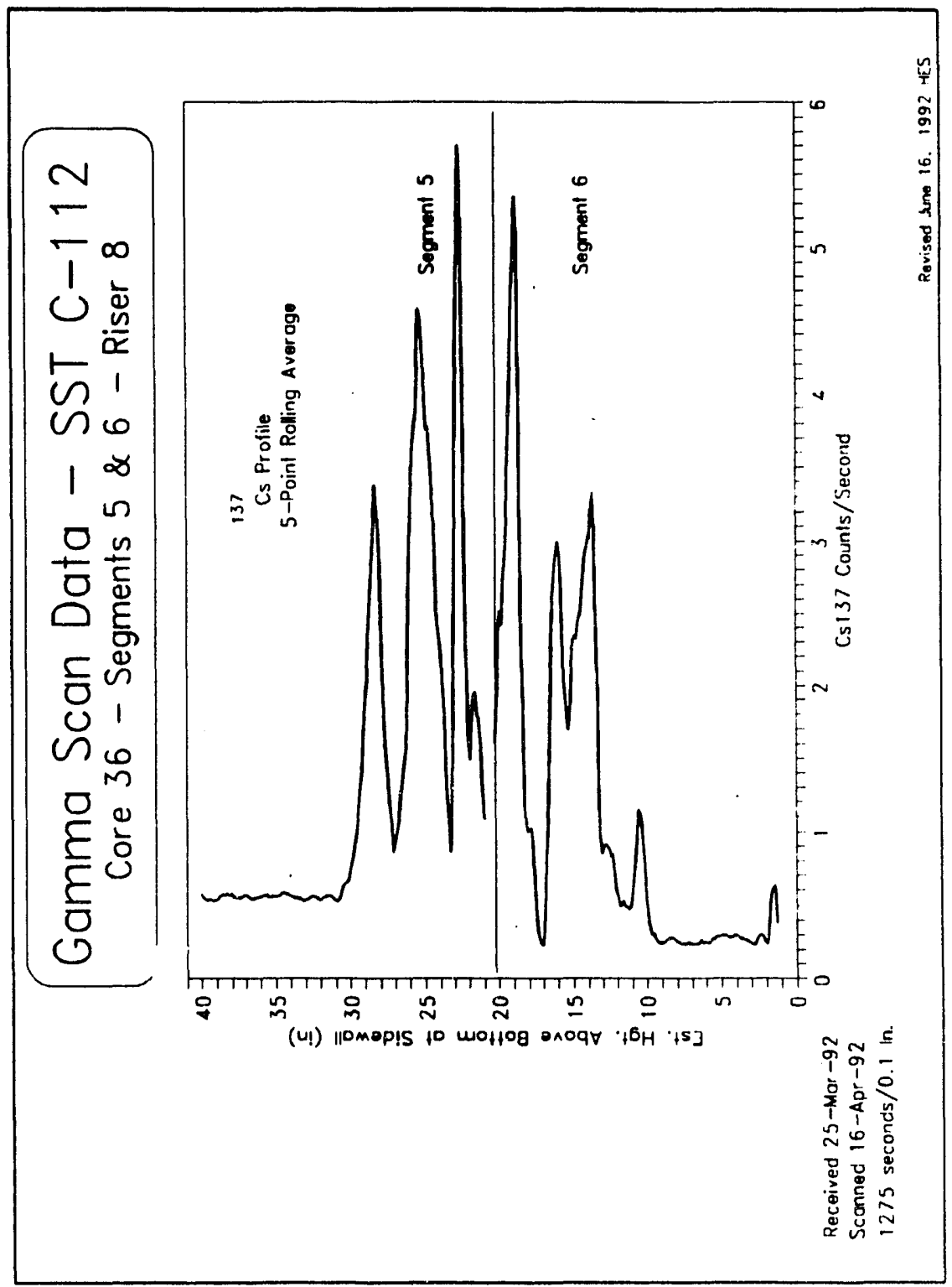




\subsection{DESCRIPTION OF SAMPLE HANDLING AND ANALYTICAL SCHEME}

\subsubsection{Sample Breakdown Procedure}

Because tank 241-C-112 has been identified as a Watch List tank (Section 2.1.2), more extensive analytical measurements are required to resolve the safety concerns associated with this tank. To enhance the resolution of the assays for key analytes, the analysis horizon for characterization was determined to be of a segment.

The sampler was removed from the shipping cask directly into the hot cel1. At this time, the sampler must be placed into the horizontal position; hence, any free liquid at the top of the sampler has an opportunity to drain to the liner. The sample was then loaded into the mechanical extruder and removed by pushing it out from the back of the sampler with a piston. In this case, the sampler is pressed against a fixed piston, forcing the sample into the extrusion tray. If a full sample has been captured, the material nearest the valve was from a deeper part of the tank; the material near the piston was closer to the surface. The sample and any liquids were collected on a metal tray. Ne't, the mass of the segment and the approximate length were recorded. From this information, the bulk densities of the segments can be estimated. The sample volume is determined by measuring the length of the extruded sample using a linear unit volume of $9.85 \mathrm{~mL} / \mathrm{in}$. Each segment was divided into $12-\mathrm{cm}$ (43-in.) subsegments. Figure 4-4 illustrates how the ferrocyanide SST segment sample was extruded and divided into subsegments. A video record of the extrusions of each of the segments from tank 241-C-112 was made, and color photographs documenting the extruded segments were taken.

Figure 4-4. Typical Single-Shell Tank Segment Extrusion.

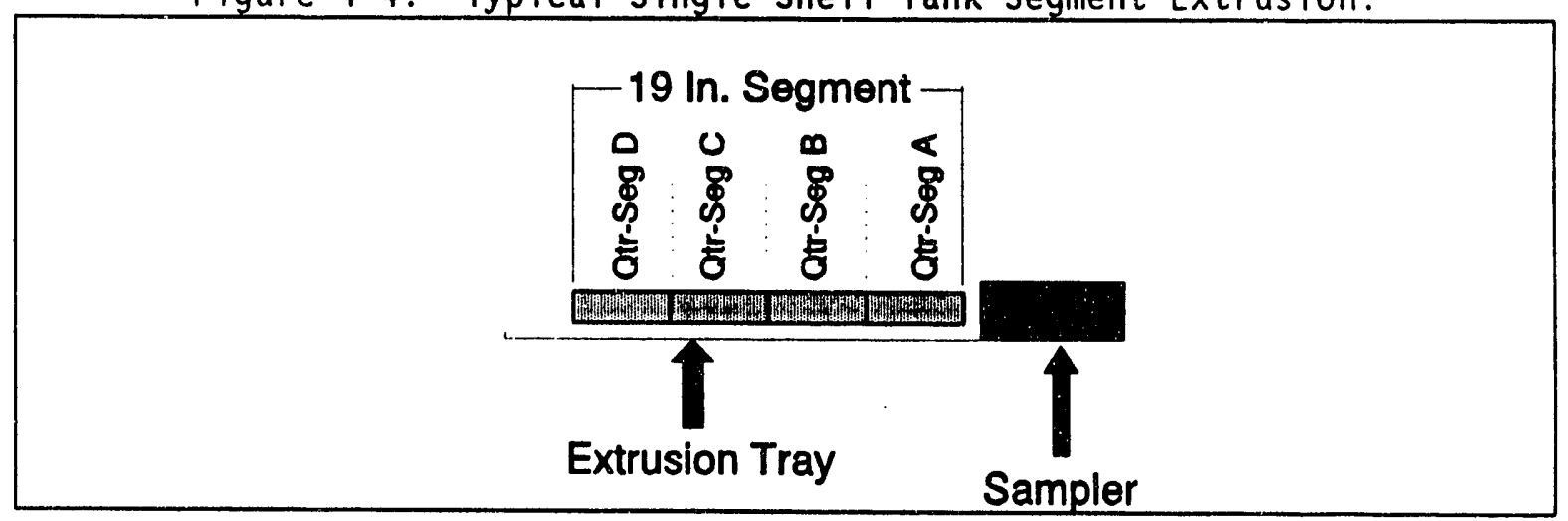

Several different styles of nomenclature are used for distinguishing core samples, sample segments, and subsegments in the existing literature. Two major conventions are used in the documentation relating to ferrocyanide (and core sampling in general). The first is designating the segment with the last two digits of the calendar "oar (92-) and then numbering the segments sequentially $(-001,-002$, etc.). This system resets itself every calendar year. The second system distinguishes the tank, core, segment, and subsegment. The first (bottom) $12 \mathrm{~cm}\left(4 \frac{3}{4} \mathrm{in.}\right)$ of the extruded sample is assigned to the fourth subsegment and is uniquely identified (Tank ID - Core No. - Segment No. - D). The following three $12-\mathrm{cm}\left(4 \frac{3}{4}-\mathrm{in}\right.$.) sections of the 
extruded segment are labelled as $C, B$, and $A$, respectively. An example of this naming protocol for the third subsegment from the second segment of the first core is (241-C-112-Core 34-Segment 2-B). If the extruded segment is less than $48 \mathrm{~cm}$ (19 in.) long, then the same naming convention applies unt $i$ ) no solid material is left to make a complete $12-\mathrm{cm}\left(4 \frac{3}{4}-\mathrm{in}\right.$.) subsegment. The first $12 \mathrm{~cm}$ ( $4 \frac{3}{4}$ in.) is be assigned to the $D$ subsegment (etc.). This second system of naming is the primary convention used in this report. Where no tank identification is given in this report, it is understood to mean tank 241-C-112.

\subsubsection{Homogenization Tests}

The subsegment and core composite samples are homogenized using a mechanical mixer prior to analysis. This is done so that aliquots removed for analysis will be representative of the entire subsegment or core composite. Aliquots of the homogenized tank waste from Core $34-2 \mathrm{C}$ and $2 \mathrm{D}$, Core $35-2 \mathrm{D}$, and Core 36-1C and 2D were taken to determine the efficacy of the homogenization procedure. The samples were split into duplicates, acid digested, and assayed by inductively coupled plasma-atomic emission spectroscopy (ICP) and gamma energy analysis. This procedure is done to determine if the degree of mixing achieved by the as-planned homogenization procedure was sufficient for the remaining samples to be homogenized and prepared for analysis. If the analytes from the aliquots are within a relative percent difference (RPD) of 10 percent, the samples are considered homogenized. If there are several analytes that are not within the specified RPD, the samples are mixed further and re-assayed. Once homogenization was indicated, the remaining samples were homogenized and prepared for analysis. The investigators reported that the samples from tank 241-C-112 exhibited substantial resistance to homogenization. Generally, the samples had to be blended twice before the ICP results were considered satisfactory. The gamma energy analys is never showed satisfactory homogenization; it indicated the distribution of radionuclides remained irregular even after the second homogenization. However, this behavior was not unexpected because the simulant materials were very resistant to dissolution. The acid digestion preparation was probably insufficient to completely dissolve the sample, and the ${ }^{137} \mathrm{Cs}$ was associated with the insoluble materials. In the future, homogenization tests of suspected ferrocyanide tanks should use a potassium hydroxide (KOH) fusion sample preparation procedure because it provides more complete dissolution of the sample.

\subsubsection{Subsegment-Level Analyses}

The objectives of subsegment-level analyses are to provide (1) information as a function of depth pertaining to the overall waste energetics, (2) the distribution of ${ }^{137} \mathrm{Cs}$ and ${ }^{90} \mathrm{Sr}$, (3) the concentration and solubility of the $\mathrm{CN}^{-}$present in the sample, and (4) a higher resolution for determining bulk tank composition for certain analytes. To accomplish these goals, the limited suite of analyses listed in Table 4-1 were performed on each homogenized subsegment. These analyses were conducted using the analytical procedures identified in Tables I5-1 and I5-2 of WHC-EP-0210, Rev 3 (Hill et al. 1991), and as amended in Hill (1991). Brief descriptions of the sample preparation and assay methods are presented. 
WHC-EP-0640

Table 4-1. Subsegment-Level Analysis.

\begin{tabular}{|c|c|c|}
\hline Direct & Fusion Dissolution & Water Leach \\
\hline $\begin{array}{c}\text { TOC/TIC } \\
\text { TGA } \\
\text { DSC } \\
\text { Total } \mathrm{CN}^{-} \\
\text {Wt\% } \mathrm{H}_{2} \mathrm{O}\end{array}$ & $\begin{array}{c}\text { ICP (Metals) } \\
\text { GEA }{ }_{\left.9 \delta_{S r}^{137} C s\right)}(s)\end{array}$ & $\begin{array}{c}\text { IC (Anions) } \\
\mathrm{CN}^{-} \\
\mathrm{pH} \\
\mathrm{GEA}\end{array}$ \\
\hline \multicolumn{3}{|c|}{$\begin{aligned} & \text { DSC }=\text { Differential scanning calorimetry. } \\
& \text { GEA }=\text { Gamma energy analysis. } \\
& \text { ICP }=\text { Induct ively coupled plasma - atomic emission } \\
& \text { ectrosCopy. } \\
& \text { TGA }=\text { Thermogravimetric analysis. } \\
& \text { TIC }=\text { Total inorganic carbon. } \\
& \text { TOC }=\text { Total organic carbon. }\end{aligned}$} \\
\hline
\end{tabular}

Direct analyses are assays performed on the sample matrix with little or no sample preparation. Several direct analyses were performed relating to the energetic properties of the waste: total organic carbon (TOC), scanning thermogravimetric analysis (TGA), DSC, total cyanide, and gravimetric weight percent water.

The TOC was determined using the hot persulfate method. That method dissolves a sample in a sulfuric acid solution $\left(90^{\circ} \mathrm{C}+\right)$ to liberate inorganic carbon (carbonate). $\mathrm{K}_{2} \mathrm{~S}_{2} \mathrm{O}_{8}$ is then added, and organic carbon is converted to $\mathrm{CO}_{2}$, which is measured coulometrically. The difficulty encountered in solubilizing the sample matrix in the homogenization tests makes the results of this assay potentially unreliable.

Scanning TGA and DSC are useful in determining the thermal stability or reactivity of a material. TGA measures the mass of a sample while the temperature of the sample is increased at a constant rate. In DSC analysis, the heat absorbed/evolved over and above the usual heat capacity of the substance is measured while the substance is exposed to a linear increase in temperature.

Total cyanide analysis was done using a developmental procedure developed at Pacific Northwest Laboratory (PNL). The sample was dissolved in a solution of ethylenediaminetetraacetic acid and ethylenediamine and placed in a microdistillation apparatus. The total cyanide content was determined by argentometric titration.

The gravimetric weight percent water was determined by drying the sample for 12 to 24 hours in an oven at 103 to $105{ }^{\circ} \mathrm{C}$ and measuring the difference in the weight of the sample.

Analyses that were performed on fusion-prepared samples were ICP and gamma energy analyses (GEA) for radionuclides. Fusion dissolution analyses are assays performed on the sample matrix after. it has been fused with potassium hydroxide in a nickel crucible and dissolved in acid. This preparation dissolves the entire sample, whereas other sample preparation 
procedures may not completely dissolve the sample matrix. However, one significant disadvantage of fusion preparation is that large amounts of potassium hydroxide are required to bring a sample into solution. Because of this high dilution factor, trace elements are less likely to be correctly quantified, if they are detected at all. Elements that occur in abundance (major metals) or are highly insoluble are likely to be detected better by the fusion results than by any other sample preparation. Generally, fusion dissolution is the preferred method of analyzing radionuclide content, with the exception of ${ }^{14} \mathrm{C}$ and ${ }^{3} \mathrm{H}$ (tritium). However, the sample preparation specified in the test instructions for ${ }^{14} \mathrm{C}$ (water digestion) is 1 ikely not the best for the ferrocyanide waste. Difficulty with dissolving the sample with a water leach, and volatility associated with a fusion preparation, will bias the ${ }^{14} \mathrm{C}$ results low for both sample preparations. An adequate sample preparation method for ${ }^{14} \mathrm{C}$ is not available for this sample matrix; however, ${ }^{14} \mathrm{C}$ is not expected to be a significant contributor to the radionuclide content of the waste.

Water leach (or water digestion) analyses are assays performed after the sample matrix has been digested in distilled/deionized water; the water is then analyzed for soluble analytes. The soluble anions are determined by ion chromatography (IC). The primary anions analyzed in this manner are fluoride, chloride, nitrate, nitrite, phosphate, and sulfate. In addition, free cyanide and $\mathrm{pH}$ were also analyzed from water digestion samples.

\subsubsection{Rheological and Physical Measurements}

Only one 25-mL aliquot (from the second segment of Core 36) was used for rheological and physical measurements. Viscosity, settling properties, fluid behavior, and shear strength were some of the primary characteristics investigated. The sample tested for these properties was not homogenized prior to analysis.

\subsubsection{Subsegment Level Archive}

Several analyses (adiabatic calorimetry, ferrocyanide speciation, and total oxygen demand [TOD]) have been identified by the Waste Tank Safety Programs as requiring developmental work. A sufficient amount of sample from each subsegment has been archived to perform these analyses when the procedures for these analyses have been developed. The adiabatic calorimetry assay will be performed on each subsegment if an exotherm of predetermined parameters is detected by DSC analysis. The boundaries for performing adiabatic calorimetry have been determined to be when the DSC exotherm is greater than $-75 \mathrm{cal} / \mathrm{g}$ and the sample has 15 wt\% water or less; or when the exotherm is greater than $-125 \mathrm{cal} / \mathrm{g}$, even if the sample has greater than $15 \mathrm{wt} \%$ water. Because of sample consumption constraints, the TOD test cannot be run for the subsegment from the rheology segment. 


\subsubsection{Core Composite Level Analysis}

One composite from each core was built and analyzed in accordance with the complete baseline case core composite scenario detailed in Section 6.1 of WHC-EP-0210 (Hill et al. 1991) and as amended by Hill (1991). The type and number of analytical tests performed are similar to the suite done on the subsegments, but are much more extensive. The free liquid from the segments in Core 34 was combined and analyzed as a separate liquid core composite. The free liquid from the segment in Core 35 was also analyzed as a liquid core composite.

Selected radionuclides were measured on some of the water digestion samples to determine the type and number of water soluble radionuclides. ICP and atomic absorption (AA) spectroscopy were al so performed on some of the water digestion samples. These assays were performed to determine the amount of soluble metal cations (ICP) or arsenic, mercury, or selenium (AA). In most cases, these analytes were below the detection limits in the water digestion samples, suggesting that most of the analytes are not water soluble.

Acid digestion is a preparation method where the sample is dissolved in a mixture of nitric and hydrochloric acids. This preparation brings most of the insoluble metals into a solution with a minimum amount of dilution, and is usually best for the detection of trace and some major metals. These properties are the reason that acid digestion is generally used as the sample preparation for the homogenization tests. The analyses performed on this preparation were the ICP, GEA, and AA analysis (the AA analysis used nitric acid only). IC analysis was not performed with the acid digestion preparation solution.

Major metals that were detected well with fusion ICP analys is for tank 24l-c-112 were aluminum, calcium, iron, sodium, and uranium; phosphorous is a non-metallic analyte detected by the ICP. In the case of these elements, the fusion result is the preferred method of analysis. Although the assay was performed in a nickel crucible, nickel values from the fusion preparation will be reported because they are important to interpreting the overall results. This is done with the understanding that they may be biased high. A zirconium crucible was initially recommended for use with these assays to eliminate any potential nickel bias, but the sample matrix reacted with the zirconium during the fusion procedure. However, potassium readings from the ICP fusion are not reported because potassium hydroxide was used to dissolve the sample and the potassium results are not important to characterizing the waste. Some of the primary radionuclides that are measured using this sample preparation are neptunium, plutonium, strontium, cesium, and technetium. A total alpha and total beta count were performed on the fusion dissolution samples as well.

A U.S. Environmental Protection Agency Contract Laboratory Procedure type organics speciation analysis was performed on the core composites. No significant levels of organic compounds were found in any of the samples, and they were not expected to contribute to the sample matrix.

In previous characterization sampling, the core composites were built using quantities of segments based on a proportion of the total weight of sample for the core (Winters et al. 1990a,b). This method assumed that the sample obtained is representative of what is in the tank. However, when 
partially filled segments are obtained, this procedure assumes that the tank does not contain any waste in this area. Incomplete recovery for a segment is more likely the result of sampling problems rather than voids in the waste.

The approach used in this analysis effort was to composite equal quantities of the homogenized subsegment material and assume that whatever is obtained in a partial subsegment is representative of a whole subsegment. Some inaccuracies may be introduced from this method because of density differences between subsegments. However, the inaccuracies introduced from density differences would probably be smail; those deviations are minimal compared to the other errors inherent in core sampling and analysis. If full segments are obtained for the entire core, and the homogenization procedure is satisfactory, there will be little difference between the two approaches. 
WHC-EP-0640

This page intentionally left blank. 


\subsection{ANALYTICAL RESULTS: TANK 241-C-112}

\subsection{TANK 241-C-112 CORE SAMPLE RECOVERY}

As shown in Figure $5-1$, the 1 ast $3.8 \mathrm{~cm}(1.5 \mathrm{in.})$ of the $48.3-\mathrm{cm}(19-\mathrm{in.})$ sampler does not secure a sample from the bottom segment. In addition, the location of the risers, the dished bottom of the tank, and safety margins in the sampling protocol preclude obtaining samples from the entire waste depth in the tank. Thus, the maximum recovery for the top segment from tank $241-C-$ 112 is $3.8 \mathrm{~cm}$ ( $1.5 \mathrm{in.}$ ) above the bit bottom to the waste surface. The next segment will likewise not obtain the lowest $3.8 \mathrm{~cm}$ (1.5 in.), but should include the $3.8 \mathrm{~cm}(1.5 \mathrm{in.})$ from the $\mathrm{N}-1$ segment for a full $48.3 \mathrm{-cm}(19-\mathrm{in}$. segment. Segment recoveries were based on the maximum recoverable volume for the segment, regardless of solid/liquid ratio. In the upper segments of tank 241-C-112 (92-001, -003 , and -005), the maximum recoverable amount of waste is $33.8 \mathrm{~cm}(13.3 \mathrm{in.})(131 \mathrm{~mL})$ and $48.3 \mathrm{~cm}(19 \mathrm{in.})(187 \mathrm{~mL})$ for the lower segments $(92-002,-004$, and -006$)$. Tables 5-1 and 5-2 present the initial measurements and observations regarding the core samples on extrusion, and an estimate of the core recovery on a volume basis.

Table 5-1. Tank 241-C-112 Core Sample Description Summary.

\begin{tabular}{|l|c|c|c|l|}
\hline Core No. & Segment & $\begin{array}{l}\text { Core Recovery } \\
\text { (Vol. basis) }\end{array}$ & $\begin{array}{c}\text { Total } \\
\text { Mass g }\end{array}$ & \multicolumn{1}{|c|}{ Comments } \\
\hline $\begin{array}{l}\text { Core 34 } \\
\text { Upper }\end{array}$ & $92-001$ & $87.0 \%$ & 136.9 & $\begin{array}{l}\text { Liquid contained suspended } \\
\text { solids. Sol ids portion was } \\
1.3 \mathrm{~cm}(0.5 \text { in.) long. }\end{array}$ \\
\hline $\begin{array}{l}\text { Core 34 } \\
\text { Lower }\end{array}$ & $92-002$ & $74.9 \%$ & 211.8 & $\begin{array}{l}\text { Grey/white streak at edge of } \\
\text { solids. Sol id segment was } \\
36.1 \mathrm{~cm} \text { (14.2 in.) long. }\end{array}$ \\
\hline $\begin{array}{l}\text { Core 35 } \\
\text { Upper }\end{array}$ & $92-002$ & $0 \%$ & N/A & $\begin{array}{l}\text { No sample recovered; } \\
\text { valve remained open. }\end{array}$ \\
\hline $\begin{array}{l}\text { Core 35 } \\
\text { Lower }\end{array}$ & $92-004$ & $34.8 \%$ & 109.1 & $\begin{array}{l}\text { Liquid contained suspended } \\
\text { solids. Sol id segment was } \\
7.6 \mathrm{~cm} \text { (3 in.) long. }\end{array}$ \\
\hline $\begin{array}{l}\text { Core 36 } \\
\text { Upper }\end{array}$ & $92-005$ & $64.9 \%$ & 105.8 & $\begin{array}{l}\text { Medium brown color; no } \\
\text { drainable liquid. Solid } \\
\text { segment was 21.8 cm (8.6 in.) } \\
\text { long. }\end{array}$ \\
\hline $\begin{array}{l}\text { Core 36 } \\
\text { Lower }\end{array}$ & $92-006$ & $90.9 \%$ & 263.7 & $\begin{array}{l}\text { Thin brown sludge at bottom } \\
\text { of segment with the material } \\
\text { gaining consistency and } \\
\text { gradual changing color to } \\
\text { grey/white moving up the } \\
\text { core. Solid segment was } \\
43.9 \mathrm{~cm} \text { (17.3 in.) long. }\end{array}$ \\
\hline
\end{tabular}


Figure 5-1. Current Condition of Tank 241-C-112.

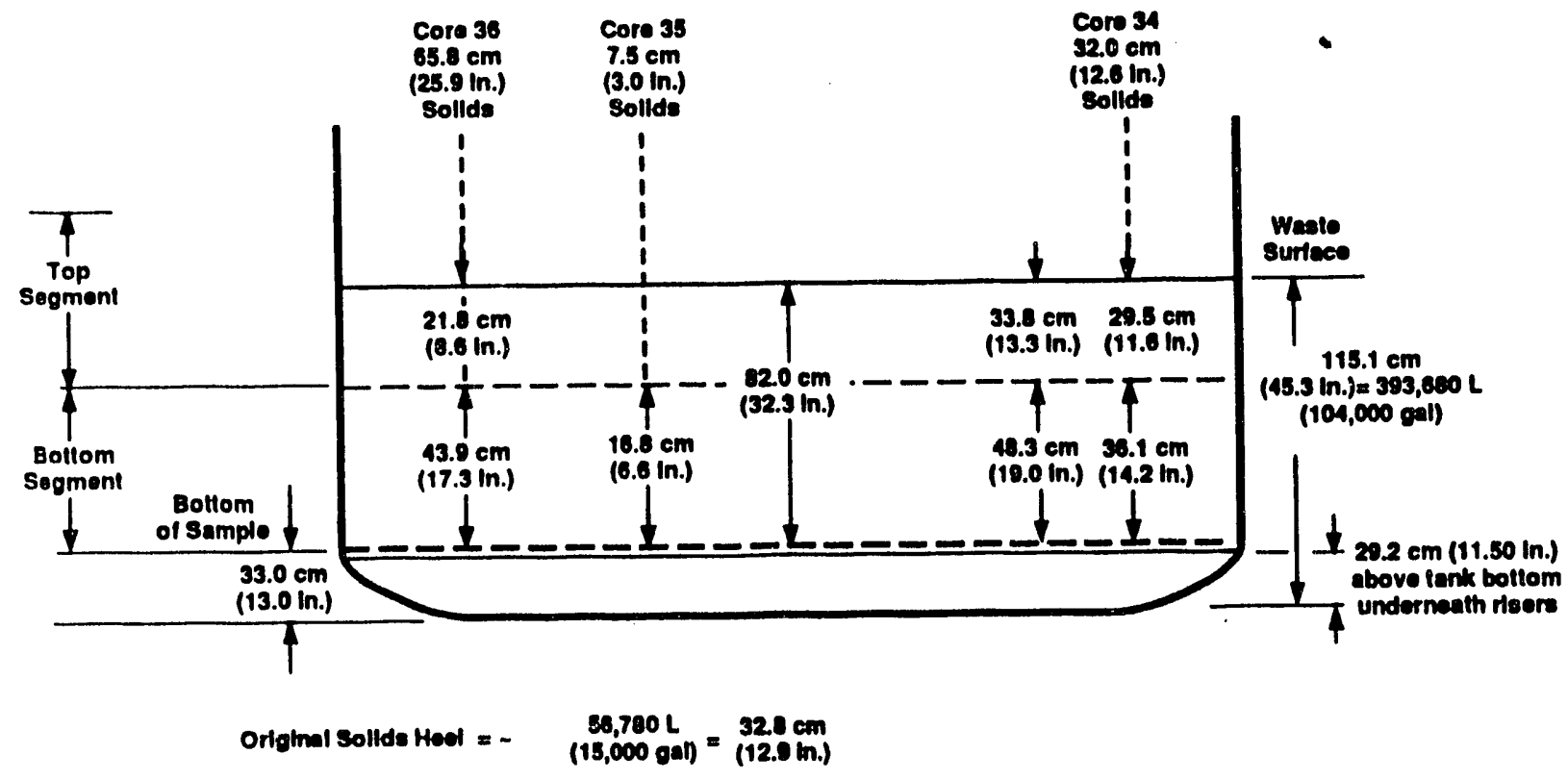

Notleseals

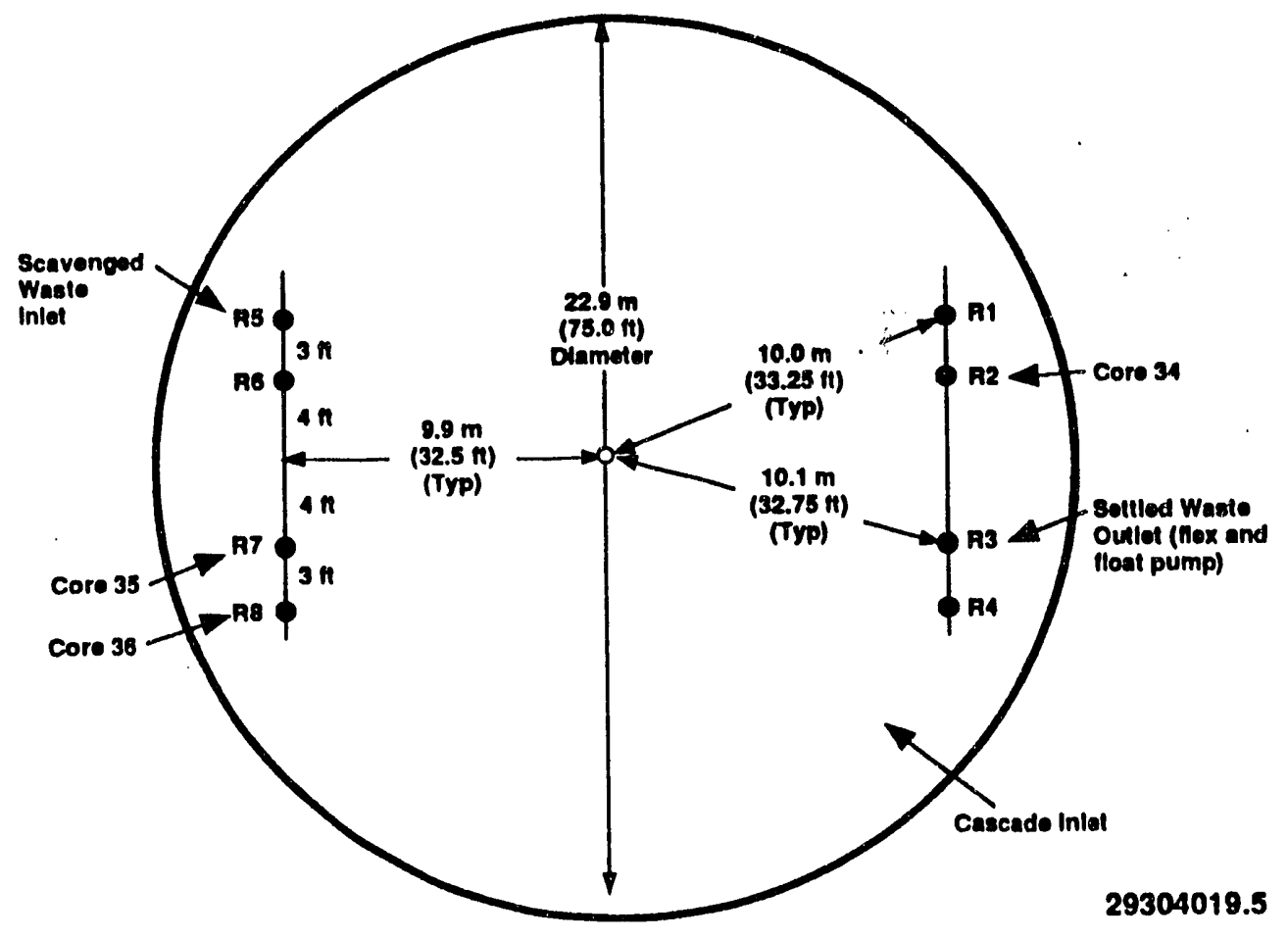


Table 5-2. Tank 241-C-112 Core Sample Physical Characteristics Summary.

\begin{tabular}{|c|c|c|c|c|c|c|c|}
\hline Core No. & Segment & $\begin{array}{c}\text { Solids } \\
\text { Sample Mass } \\
\text { (g) }\end{array}$ & $\begin{array}{c}\text { Liquid } \\
\text { Sample Mass } \\
\text { (g) }\end{array}$ & $\begin{array}{l}\text { Sol ids } \\
\text { Sample } \\
\text { Volume } \\
\text { (mL) }\end{array}$ & $\begin{array}{l}\text { Liquid } \\
\text { Sample } \\
\text { Volume } \\
\text { (mL) }\end{array}$ & $\begin{array}{l}\text { Solids Bulk } \\
\text { Density } \\
(\mathrm{g} / \mathrm{mL})\end{array}$ & $\begin{array}{l}\text { Liquids } \\
\text { Bulk } \\
\text { Density } \\
(\mathrm{g} / \mathrm{mL})\end{array}$ \\
\hline Core 34 & $92-001$ & 20.99 & 115.89 & 14 & 100 & 1.5 & 1.2 \\
\hline Core 34 & 92.002 & 175.75 & 36.07 & 110 & 30 & 1.6 & 1.2 \\
\hline Core 35 & $92-003$ & $N / A$ & $N / A$ & 0 & 0 & $N / A$ & $N / A$ \\
\hline Core 35 & 92.004 & 58.7 & 50.35 & 30 & 35 & 2.0 & 1.4 \\
\hline Core 36 & $92-005$ & 105.8 & 0.0 & 85 & 0 & 1.2 & None \\
\hline Core 36 & $92-006$ & 263.7 & 0.0 & 170 & 0 & 1.6 & None \\
\hline
\end{tabular}

Solids: wet solids

Liquid: drainable (free) liquid

General characteristics of tank $241-C-112$ waste materials are as follows.

- Drainable liquids were all rust to dark brown in color and contained significant amounts of suspended solids. After filtering, the liquids were dark yellow.

- Core samples ranged from grey/white to tan/dark brown in color. No sharp boundaries were observed in the samples. The changes in color occurred gradualiy over the sample length.

- The samples also ranged in consistency from a thin slurry to a very thick, chunky sludge. They appeared to be saturated with liquid.

- The samples slumped somewhat, but held their shape relatively well (high viscosity, non-Newtonian fluids).

The next several figures (Figures 5-2, 5-3, and 5-4) present the values most relevant for evaluation of the ferrocyanide USQ. Summary tables of the most significant components are also provided. Analysis of the samples was performed at the PNL Analytical Chemistry Laboratory facility in the 300 Area of the Hanford Site. The full data package is available from the Hanford Analytical Services Management Office (HASM 1993).

\subsection{TANK 241-C-112 CORE SAMPLE RHEOLOGICAL/PHYSICAL MEASUREMENTS}

Measurements of physical properties such as shear strength, viscosity, particle size, and settling properties were measured. These measurements are necessary for the design and fabrication of retrieval, pretreatment, and final waste disposal systems. 
Figure 5-2. Segments 1 and 2, Core 34 Measurements and Observations.

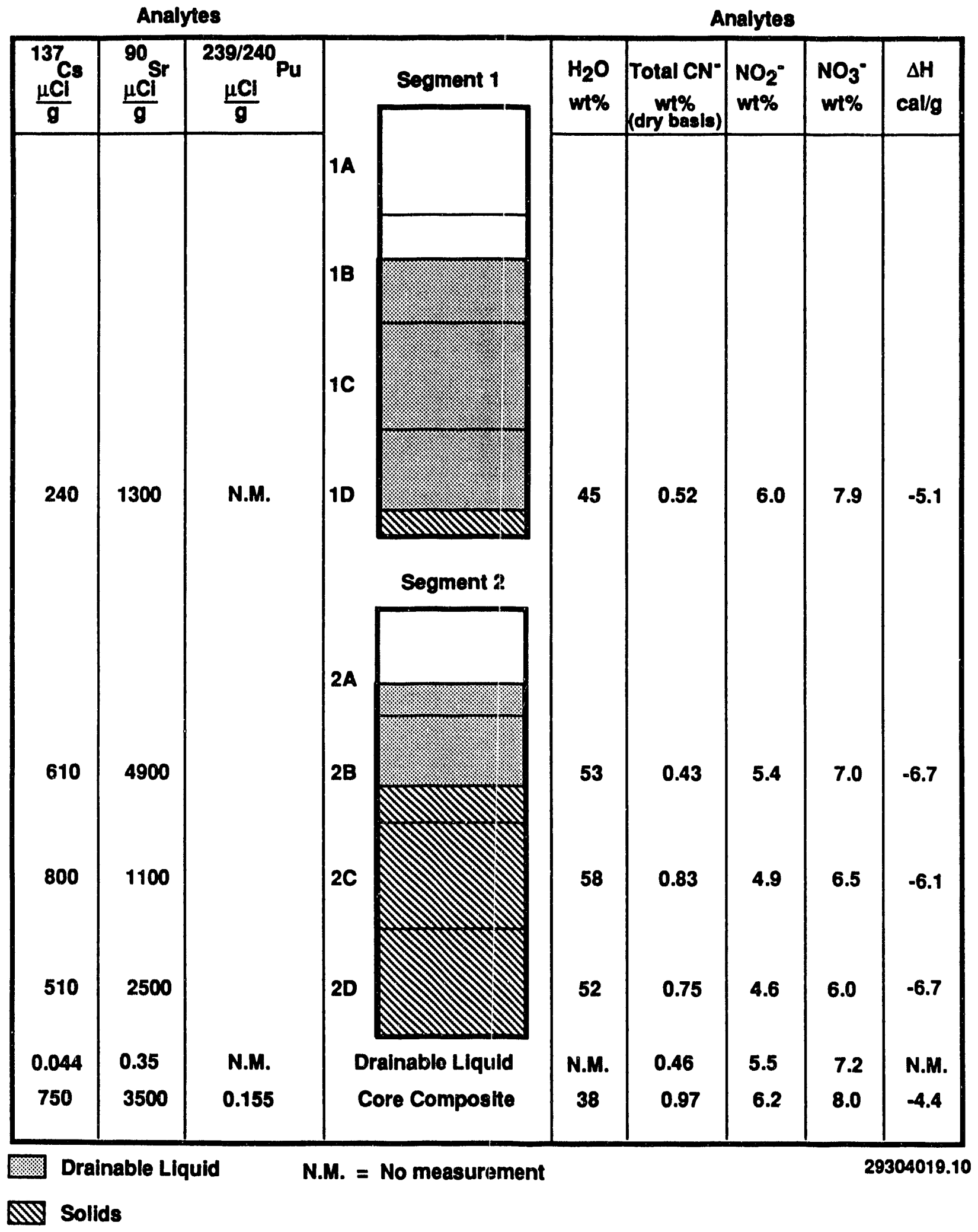


Figure 5-3. Segments 1 and 2, Core 35 Measurements and Observations.

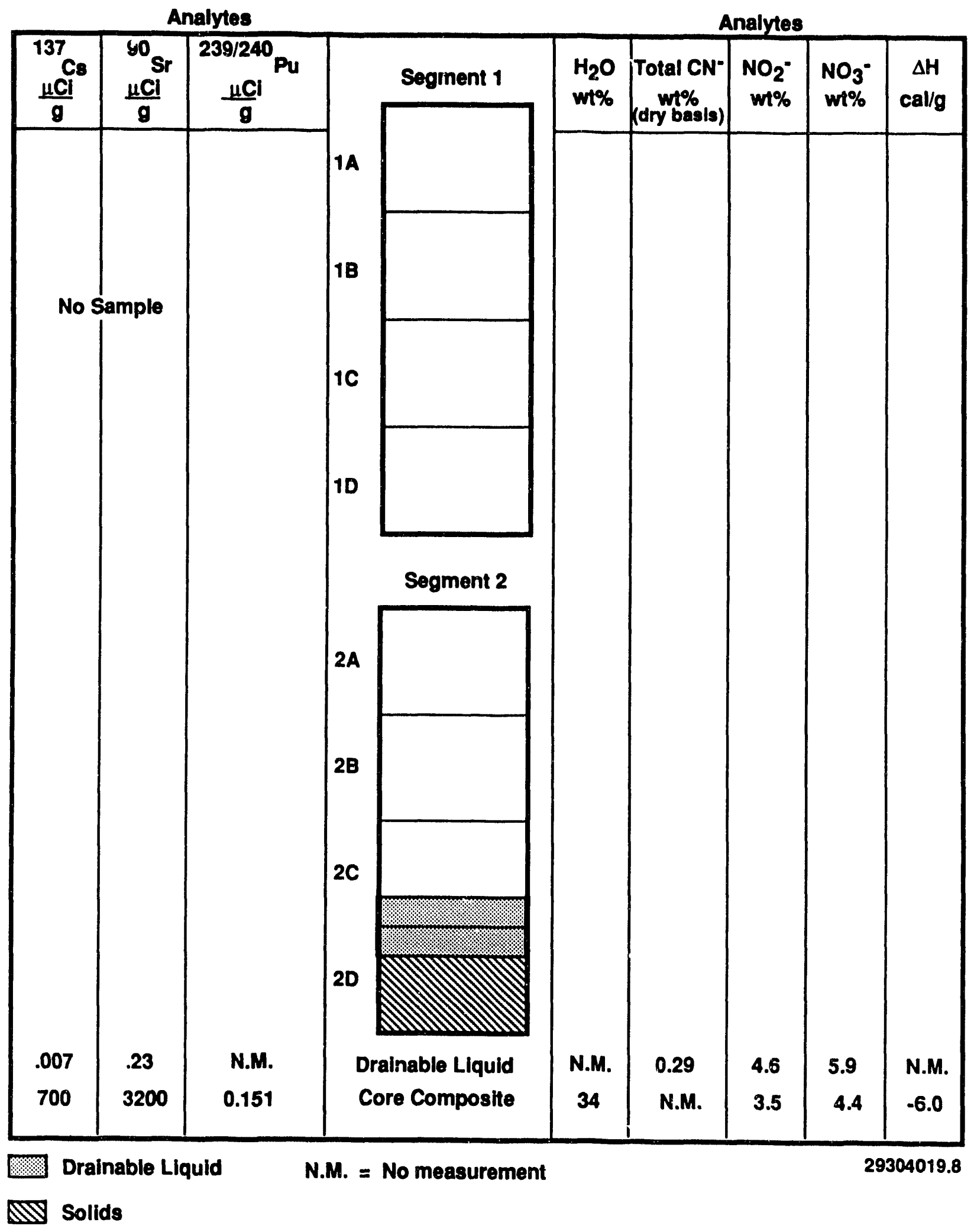


Figure 5-4. Segments 1 and 2, Core 36 Measurements and Observations.

Analytes

Analytes

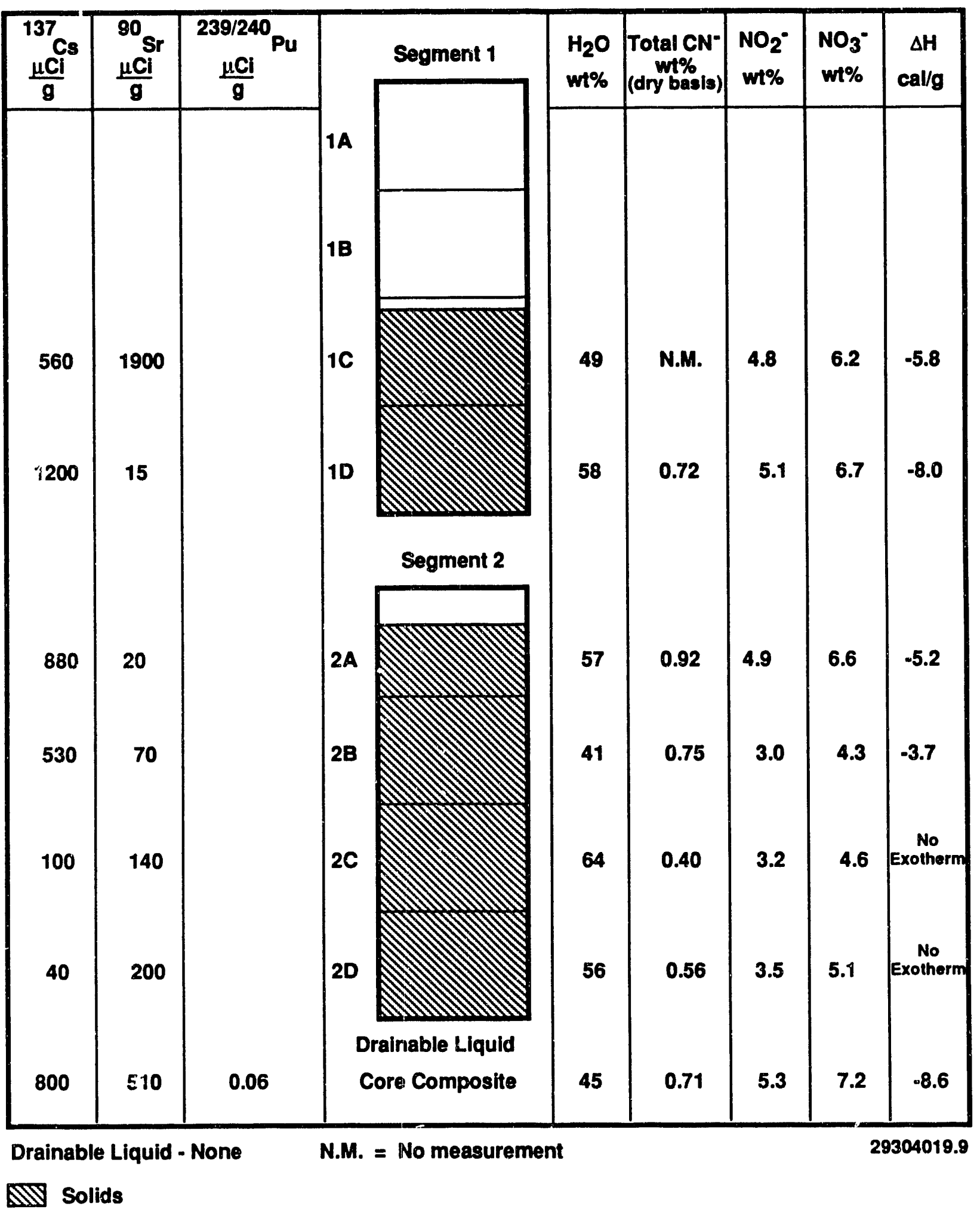




\subsubsection{Shear Strength}

The shear strength of tank 241-C-112 Core 36 was measured on a combined, unhomogenized sample obtained from both segments of the core. The shear strength measurements were made at ambient temperature using a shear vane connected to a viscometer and rotated at $0.3 \mathrm{rpm}$. Shear strength $\left(\tau_{\mathrm{s}}\right)$ is a semiquantitative measurement of the force required to move the sample. Because shear strength is dependent on sample handling, the measurement was taken without any sample homogenization. The rheology sample was generated by taking small aliquots from the bottom segment of Core 36 at various positions. The aliquots were transferred to a sample jar and allowed to settle for 10 weeks to let the sample recover from the disturbance of sampling and extrusion. The extended delay between sample and analys is was permitted because it is believed that the longer the sample sits undisturbed, the more likely it is to return to its (nearly) original condition; therefore, the shear measurement is likely to be more representative. The shear stress $\left(S_{1}\right)$ of the sample was recorded as a function of time and the shear strength was calculated using Equation 1.

$$
\tau_{s}=\frac{[8 \tau / 100] * S_{\tau} * 4.9 E+05}{\frac{\pi * H_{v} * D_{v}^{2}}{2}+\frac{\pi * D_{v}^{3}}{6}}
$$

where: $\% \tau / 100=$ the ratio of the total torque which is recorded as full scale on the plot of the shear stress

$$
\begin{array}{ll}
S_{r} & =\text { shear stress } \\
4.9 E+05 & =\text { maximum torque of the viscometer head (dynes) } \\
H_{v} & =\text { shear vane height }(0.635 \mathrm{~cm}) \\
D_{v} & =\text { shear vane diameter }(0.635 \mathrm{~cm})
\end{array}
$$

Shear strength for the sample was found to be 16,000 dynes $/ \mathrm{cm}^{2}$. Relative percent difference between initial and duplicate measurements of the sample was less than 1 percent.

\subsubsection{Viscosity as a Function of Shear Rate}

Viscosity measurements (as a function of shear rate) were performed on the composite sample and the 1:1 sample:water dilution of the sample at ambient hot cell temperatures 29 to $32{ }^{\circ} \mathrm{C}\left(84\right.$ to $\left.90^{\circ} \mathrm{F}\right)$ and at $95^{\circ} \mathrm{C}\left(203{ }^{\circ} \mathrm{F}\right)$. At $95^{\circ} \mathrm{C}$ the undiluted core composite sample dried too quickly to obtain an accurate viscosity measurement; therefore, no data are presented for the undiluted sample at that temperature. The rheological properties for the undiluted sample were not characteristic of any accepted behavior models. In addition, the undiluted sample behavior at high shear rates is considered suspect. Viscosity of the undiluted sample at low shear ranged from 160,000 to 220,000 cP. The 1:1 dilution of the composite sample exhibited 
yield-pseudoplastic behavior. Plots of the measurements can be found in the summary data packages or in the full validated data packages (HASM 1993). Viscosities as a function of shear rate for the 1:1 dilutions ranged from $400 \mathrm{CP}$ (at low shear rates) to $50 \mathrm{cP}$ (at high shear rates).

Further measurements of the shear stress as a function of shear rate were made on the 1:3 dilution samples at ambient temperature and at $95^{\circ} \mathrm{C}\left(203{ }^{\circ} \mathrm{F}\right)$. The ambient samples were run in duplicate; however, due to drying of the sample, only a single measurement could be performed at $95^{\circ} \mathrm{C}\left(203^{\circ} \mathrm{F}\right)$. $\mathrm{All}$ of the $1: 3$ diluted samples had viscosities near the detection limit of the apparatus ( $2 \mathrm{CP}$ ). The diluted samples also exhibit yield-pseudoplastic behavior. But, at viscosities near the detection limit, accurate modeling of the flow properties with this data becomes difficult. The viscosity of the sample was observed to decrease significantly as the temperature increased.

The data from the rheograms for the 1:1 dilution were fit to a nonlinear yield power-law model (Equation 2). Sample and duplicate measurements were run at ambient and $95^{\circ} \mathrm{C}$.

$$
S_{\tau}=\alpha+\beta \gamma^{n}
$$

where

$$
\begin{aligned}
& S_{r}=\text { shear stress } \\
& \alpha=\text { yield stress (not a fit parameter) } \\
& \beta=\text { consistency factor } \\
& \gamma=\text { shear rate }\left(0 \text { to } 468 \mathrm{~s}^{-1}\right) \\
& n=\text { flow behavior index }
\end{aligned}
$$

Table 5-3 presents the power law model parameters for the $1: 1$ sample dilutions at 29 and $95^{\circ} \mathrm{C}$.

Table 5-3. Power-Law Model Parameters for Tank 241-C-112 Material.

\begin{tabular}{|c|c|c|c|c|c|}
\hline Sample & $\begin{array}{c}\text { Temperature } \\
\left({ }^{\circ} \mathrm{C}\right)\end{array}$ & Trial & $\begin{array}{c}\alpha, \text { Yield } \\
\text { Stress (Pa) }\end{array}$ & $\begin{array}{c}\beta \text {, Consistency } \\
\text { Factor (Pa } \bullet \text { S })\end{array}$ & $\begin{array}{c}\text { n, Flow } \\
\text { Behavior } \\
\text { Index }\end{array}$ \\
\hline $1: 1$ Dilution & 29 & S & 6.8 & 0.279 & 0.576 \\
\hline $1: 1$ Dilution & 29 & $\mathrm{D}$ & 5.8 & 0.302 & 0.534 \\
\hline $1: 1$ Dilution & 95 & $\mathrm{~S}$ & 3.6 & 0.079 & 0.68 \\
\hline $1: 1$ Dilution & 95 & $\mathrm{D}$ & 4 & 0.097 & 0.648 \\
\hline
\end{tabular}

$S=$ Sample

$D=$ Duplicate.

A rheogram for a material with a yield stress has two sections. The first section is a straight line beginning at the origin and climbing up the ordinate. This portion of the rheogram records the material as it acts like a solid or gel. When sufficient force is applied to the material to make the gel yield, the rheogram breaks sharply to the right; recording the material's behavior as a fluid. The point on the rheogram at which the sample's behavior transfers from a solid or gel to a fluid is the yield point or yield stress. 
The consistency factor in this model is analogous to viscosity. The flow behavior index indicates the degree of deviation from Newtonian behavior. For values less than 1 , the behavior is considered pseudoplastic (Bird et al. 1960).

\subsubsection{Slurry Flow Properties}

Characteristics necessary for turbulent flow were calculated for the 1:1 dilution slurry using the parameters determined from measurement and a curve-fitted rheological model (refer to Table 5-4). Turbulent flow is necessary to keep particles in suspension and prevent the accumulation of the waste in a retrieval and/or pretreatment process.

Table 5-4. Turbulent Flow Mode? Calculations.

\begin{tabular}{|c|c|c|c|c|c|c|}
\hline Sample & $\begin{array}{c}\text { Temp. } \\
\left({ }^{\circ} \mathrm{C}\right)\end{array}$ & Trial & $\begin{array}{c}\text { Pipe Dia. } \\
(\text { in. })\end{array}$ & $\begin{array}{c}\text { Velocity } \\
(\mathrm{m} / \mathrm{s})\end{array}$ & $\begin{array}{c}\text { Critical Flow } \\
\text { Rate (L/min) }\end{array}$ & $\begin{array}{c}\text { Reynolds } \\
\text { Number }\end{array}$ \\
\hline $1: 1$ Dilution & 29 & S & 2 & 1.9 & 246 & 4,425 \\
\hline $1: 1$ Dilution & 29 & D & 2 & 1.7 & 220 & 4,470 \\
\hline $1: 1$ Dilution & 29 & S & 3 & 1.7 & 496 & 4,920 \\
\hline $1: 1$ Dilution & 29 & D & 3 & 1.6 & 447 & 4,908 \\
\hline $1: 1$ Dilution & 95 & S & 2 & 1.3 & 163 & 5,190 \\
\hline $1: 1$ Dilution & 95 & D & 2 & 1.3 & 170 & 5,214 \\
\hline $1: 1$ Dilution & 95 & S & 3 & 1.2 & 329 & 6,002 \\
\hline $1: 1$ Dilution & 95 & D & 3 & 1.2 & 344 & 5,997 \\
\hline
\end{tabular}

\subsubsection{Particle Size Measurement}

Particle size analysis is performed by placing a small amount of sample in a dispersant (which is the liquid used to disperse and suspend the particles from the solid sample). The prepared sample was placed in a particle size analyzer. The apparatus measures particle size by passing a thin beam of laser light through the dispersant. The diameter of a particle of matter in the dispersant can be determined by the amount of light that it blocks as the particle passes through the beam. The dimension measured by this method is the value across the short diameter of the particle. This means that if a particle is oblong, the machine estimates the shortest length across the particle (i.e., the width of the oblong shape, not the length). The term "diameter" throughout this text will be used to describe any linear profile of any shape.

An important consideration involving the analysis of particle size is the dispersant used. The primary concern involved with the dispersant is dissolving the particle. Any particles existing in the tank that are soluble in the dispersant will dissolve or decrease in size during the analysis. 
Depending on the dispersant, the particle size analysis may not represent the true particle size distribution in the tank. In the case of tank 241-c-112, a mixture of water and glycerin was used as the dispersing medium. If a "true" particle size distribution is required, the mother liquor (drainable liquid) of the tank should be used, if possible, because the tank particulates are already in equilibrium with the tank mother liquor. The high insolubility of the waste matrix suggests that the particle size data acquired should be acceptable. However, if the ferrocyanide waste has been hydrolyzed by high-pH waste, this assumption may not be completely accurate.

The mean particle size in the number distribution ranges from 0.83 microns to 0.95 micron in diameter for the tank core samples. Table 5-5 presents the summary results of the measurements. Plots of the distributions are presented as Figures 5-5 and 5-6. The first graph is the probability number density. The number density graph is plotted over the acouisition range of the device (from 0.5 to 150 microns). The numbers of particles in each size range (shown as a percentage of the whole) are graphed against their respective size ranges to form a distribution curve. It can be seen from Figure 5-5 that the most common occurrences (modes) for particle size range between 0.5 and 1.0 microns. The majority (over 90 percent) of the measured particles fit within the narrow band of 0.4 to 1.5 microns, and over 97 percent of the particles have a diameter of less than 2 microns.

Table 5-5. Particle Size Distribution by Number: $97 \%<2 \mu \mathrm{m}$ (both cores).

\begin{tabular}{|c|c|c|}
\hline Sample & Mean $(\mu \mathrm{m})$ & Median $(\mu \mathrm{m})$ \\
\hline Core 34, subsegment 2D, Initial & 0.83 & 0.76 \\
\hline Core 34, subsegment 2D, Duplicate & 0.94 & 0.83 \\
\hline Core 36, 92-005 (random sample) & 0.95 & 0.84 \\
\hline
\end{tabular}

The particle size in the volume distribution ranges from 0.4 microns to 80 microns in diameter between the two cores. Table 5-6 presents the summary results of the measurements. Under the assumption that the density of the solid material within the tank is constant, the volume distribution is also the best estimation of the mass particle size distribution of the tank. The analyzer calculates particle volume as the cube of the diameter. These distributions are presented as Figures 5-7 and 5-8.

Table 5-6. Particle Size Distribution by Volume: $100 \%<30 \mu \mathrm{m}(34-20) ; 100 \%<85 \mu \mathrm{m}(36)$.

\begin{tabular}{|c|c|c|}
\hline Sample & Mean $(\mu \mathrm{m})$ & Median $(\mu \mathrm{m})$ \\
\hline Core 34, subsegment 2D, Initial & 8.68 & 6.05 \\
\hline Core 34, subsegment 2D, Duplicate & 9.60 & 6.32 \\
\hline Core 36, 92-005 (random sample) & 33.77 & 33.26 \\
\hline
\end{tabular}


Figure 5-5. Core 34, Particle Size Number Density.

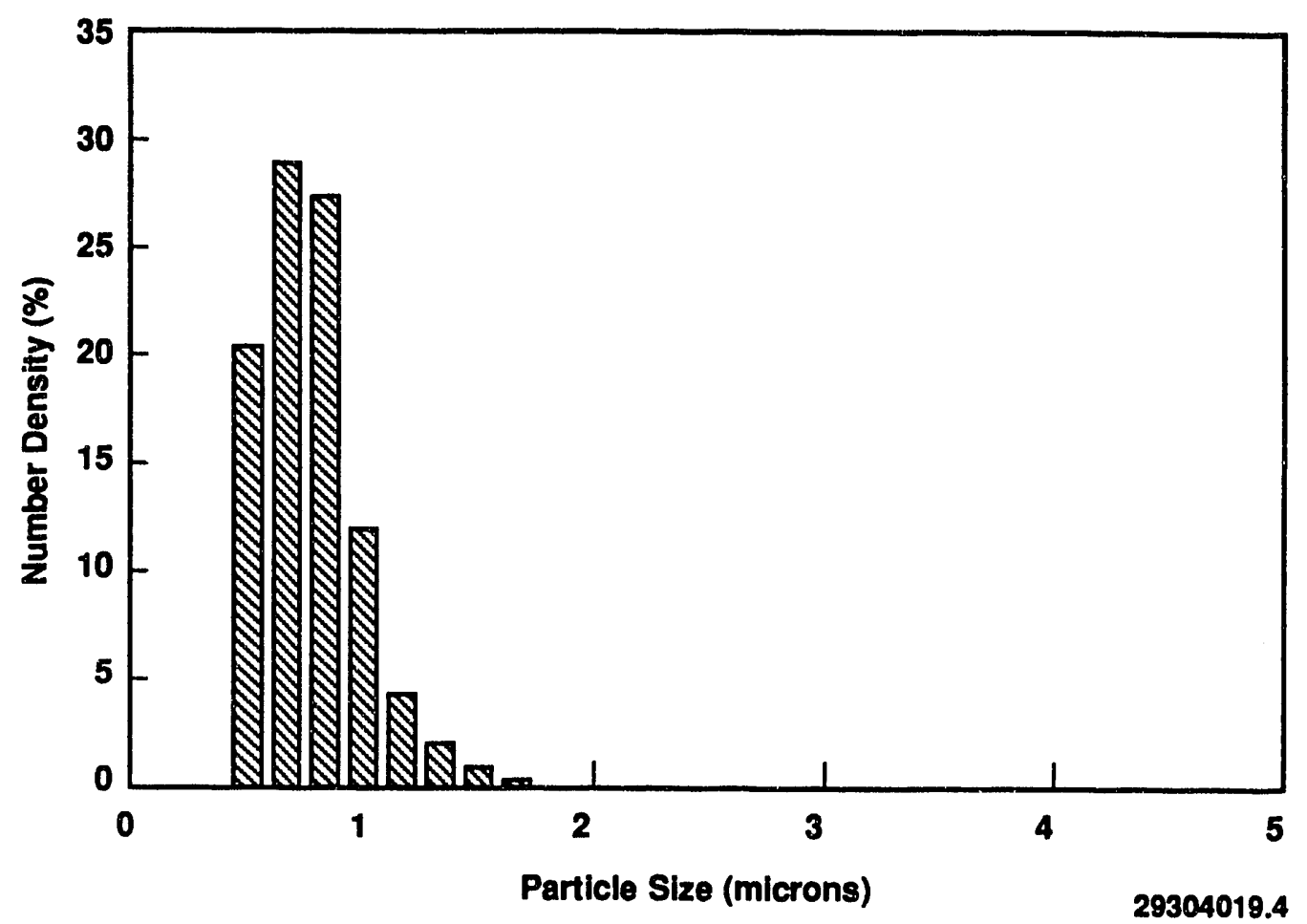

Figure 5-6. Core 36, Particle Size Number Density.

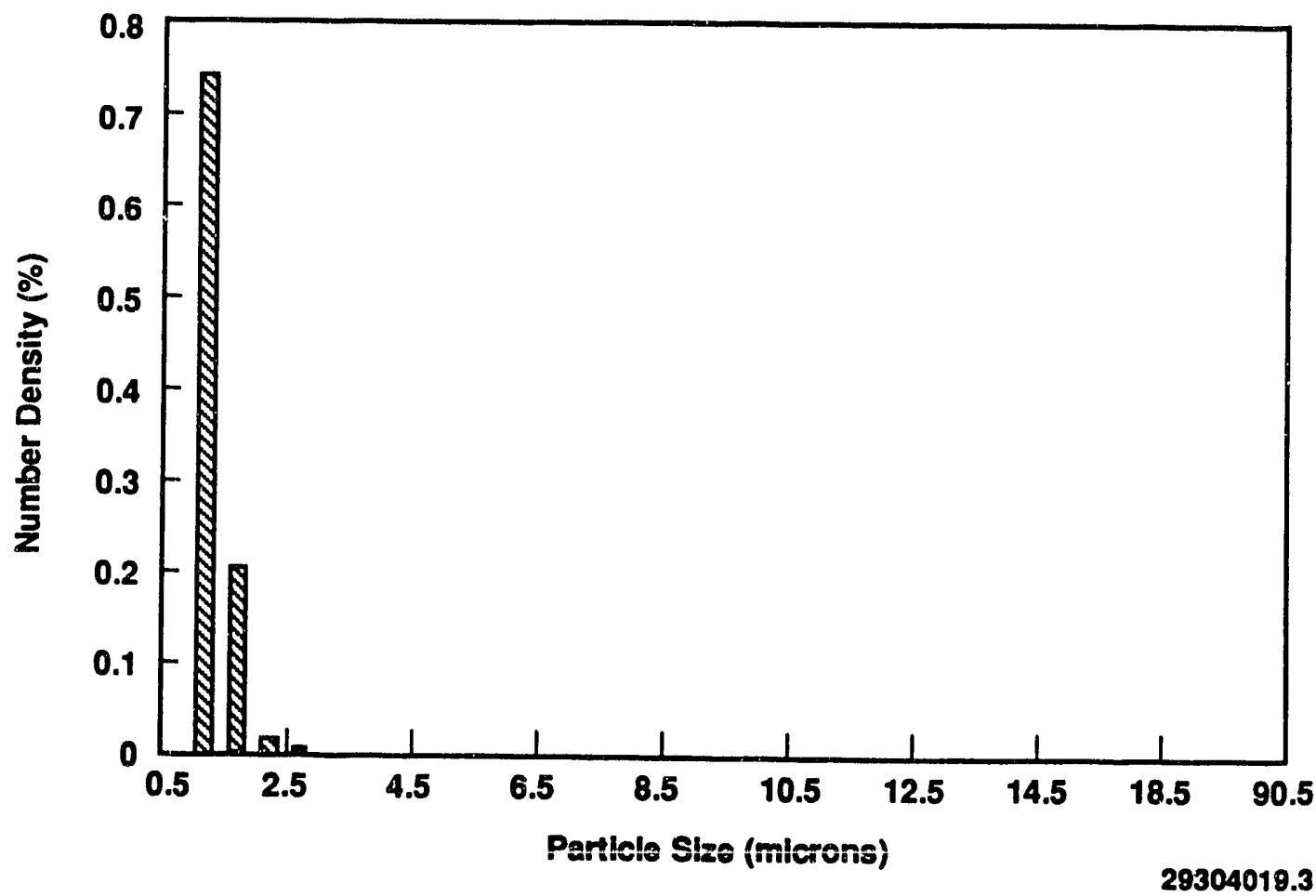


WHC-EP-0640

Figure 5-7. Single-Shell Tank Core 34, Particle Size Volume Density.

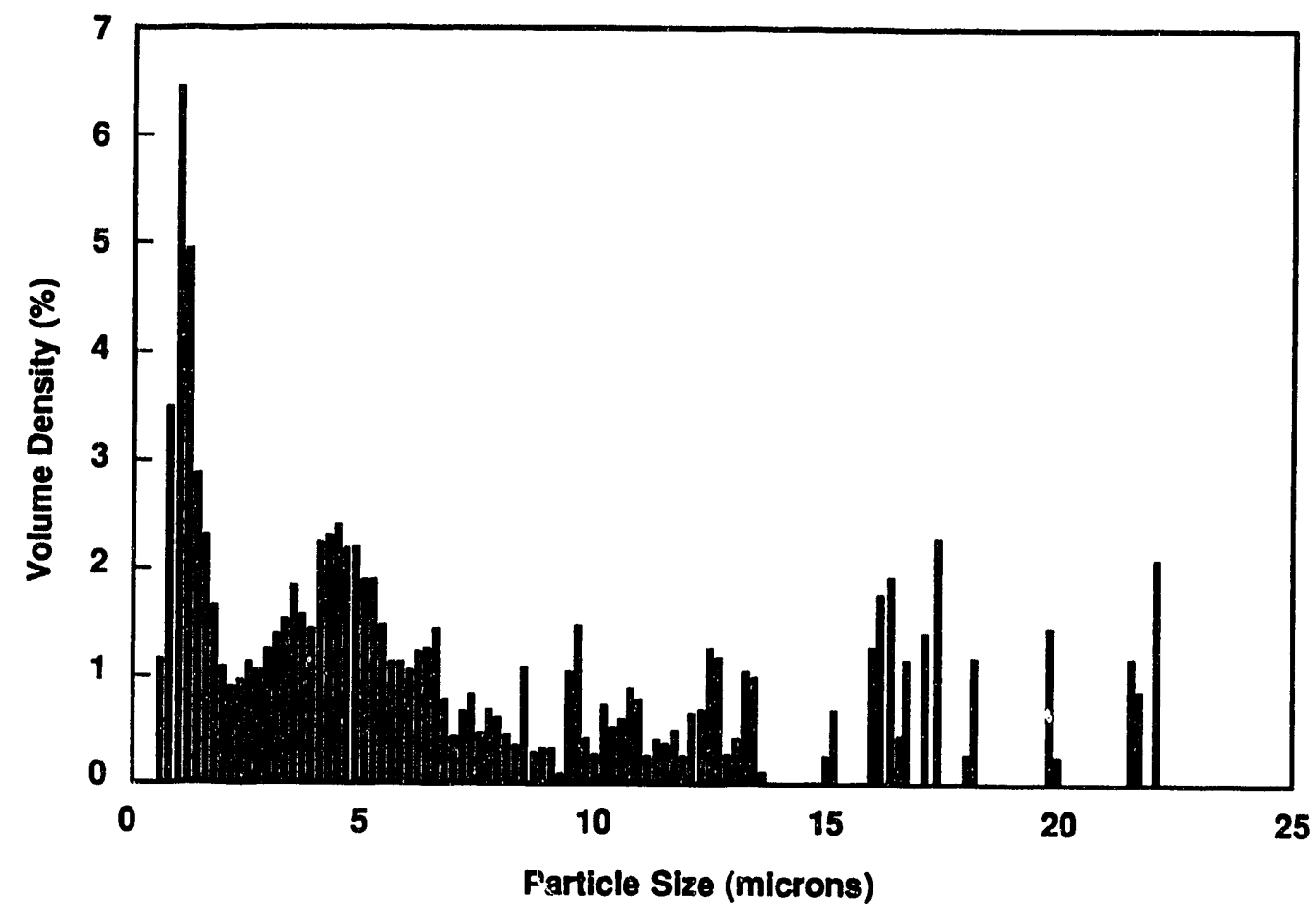


Figure 5-8. Single-Shell Tank Core 36, Particle Size Volume Density.

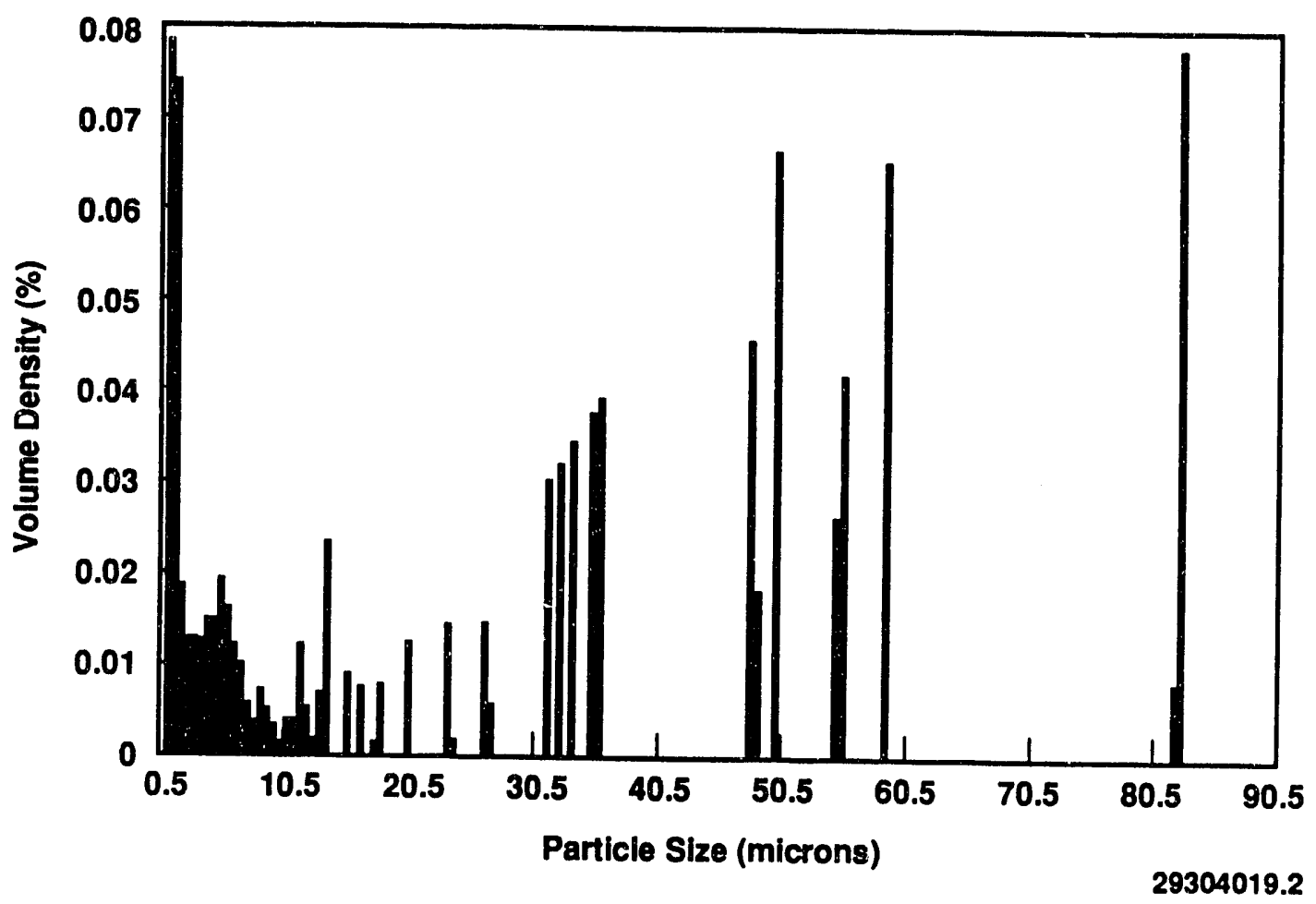


As with the number distribution, the volume distribution is represented by a probability volume density graph. The average particle size in the volume distribution is considerably larger than that of the number distribution. In Core 34 most of the particles are within the 2.0 to 20 micron range. In Core 36 most of the particles are much larger, with particle volumes widely dispersed in the 20 to 80 micron range.

The disparity between the two core sample measurements possibly indicates a difference in waste type. In Core 34-2D, over 50 percent of the particles in the sample have a diameter of less than 6 microns, with close agreement from the duplicate measurement. In the Core 36 sample over 50 percent of the particles have a diameter of less than 33 microns. In the retrieval and subsequent treatment of the tank wastes, it may be desirable to design pumping or filtration systems for the tank particulate. Therefore, the volume distribution of the particles should not be neglected (i.e., particles with diameters of over 33 microns should be considered in these designs).

\subsubsection{Settling Behavior of Diluted Samples}

This siction analyzes the settling behavior for the $1: 1$ and $3: 1$ water/sample dilutions and the viscosity as a function of shear rate on the $3: 1$ dilution. All results for the as-received material and the viscosity for the 1:1 dilution have been previously reported (HASM 1993). The physical properties reported here include settling rates and volume percent settled solids, and weight percent and volume percent centrifuged solids for the $3: 1$ dilution and settling rates and volume percent settled solids for the 1:1 dilution. The experimental procedures used to perform these measurements were reported previously (HASM 1993).

The physical properties of the $1: 1$ and $3: 1$ dilutions are summarized in Table 5-7.

Table 5-7. Physical Properties Summary.

\begin{tabular}{|c|c|c|}
\hline \multirow{2}{*}{ Property } & \multicolumn{2}{|c|}{ Segment } \\
\cline { 2 - 3 } & $1: 1$ Dilution & $3: 1$ Dilution \\
\hline Settled Solids (vol\%) & 74.4 & 72.4 \\
\hline Centrifuged Solids & NM & 21.1 \\
\hline Vol\% & NM & 27.0 \\
\hline Wt\% & & \\
\hline Density (g/ml) & NM & 1.11 \\
\hline Sample & NM & 1.01 \\
\hline Centrifuged Supernate & NM & 1.39 \\
\hline Centrifuged Solid &
\end{tabular}

NM $=$ No measurement. 
No settling was observed in the as-received segment samples over a period of 3 days. Two dilutions (1:1 and $3: 1$ water to sample) were prepared, and the volume percent settled solids for each of the dilutions are plotted as a function of settling time (as shown below in Figures 5-9 and 5-10).

The 1:1 dilution reaches a final volume percent settled solids of 74.4 percent. Settling is observed throughout the 3 -day period, but the majority of the settling is observed in the first 30 hours. The $3: 1$ dilution reaches a final volume percent settled solids of 72.4 percent. The majority of the solids settling is complete within 24 hours. Figures 5-9 and 5-10 illustrate the setting behavior over time.

\subsection{ANALYTICAL RESULTS--INDUCTIVELY COUPLED PLASMA- ATOMIC EMISSION SPECTROSCOPY}

\subsubsection{Inductively Coupled Plasma Assays--General Comments}

No online multiple inter-element corrections were performed for matrix interferences. The ICP has built-in correction capability to adjust for moderate matrix interferences; however, this function does not perform well on samples containing weight percent quantities of iron, aluminum, or uranium. Single pass off-line corrections were performed to correct for high aluminum, iron, and uranium content in the samples. Process blank values have not been subtracted from the results (except for nickel-fusion and quality Control results). In the water digestion and drainable liquid assays, the single most prevalent element is sodium, by at least an order of magnitude. In the fusion assays, some elements (lead, for example) appear to be at high concentrations because of the large dilution factors required for fusion samples. Those analytes may actually only be present in concentrations marginally above the detection limit. Selenium routinely demonstrated a low bias; however, it is not a major analyte in the waste matrix. An estimate of the detection limit for any analyte can be obtained by multiplying the analyte's dilution factor by the appropriate sample " $\mu \mathrm{g} / \mathrm{g}$ Factor" found in the data packages. Analytes reported in the data tables are those consistently contributing significant amounts to the composition of the waste matrix; average values for the analytes are reported to 3 significant figures. The full range of ICP analytes can be found in the full data packages (HASM 1993). All reported concentration values are based on grams of wet sample, unless otherwise specified.

Tables 5-8, 5-9, and 5-10 provide ICP analyte concentration information on the core composites as a function of the sample preparation. 
WHC-EP-0640

Figure 5-9. Settling Rate Data for Tank 241-C-112 Core 36, 1:1 Dilution.

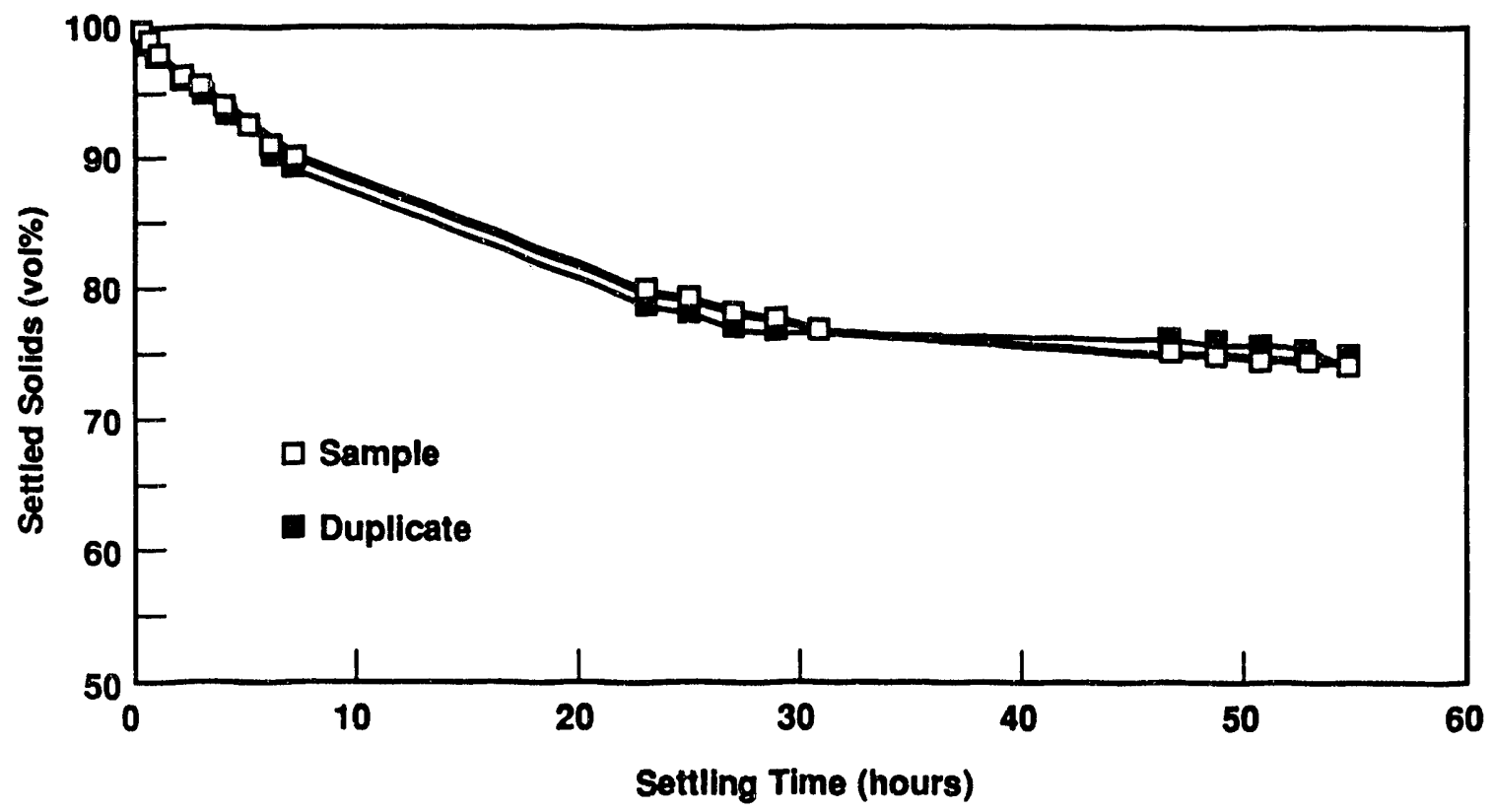

Figure 5-10. Settling Rate Data for Tank 241-C-112 Core 36, 3:1 Dilution.

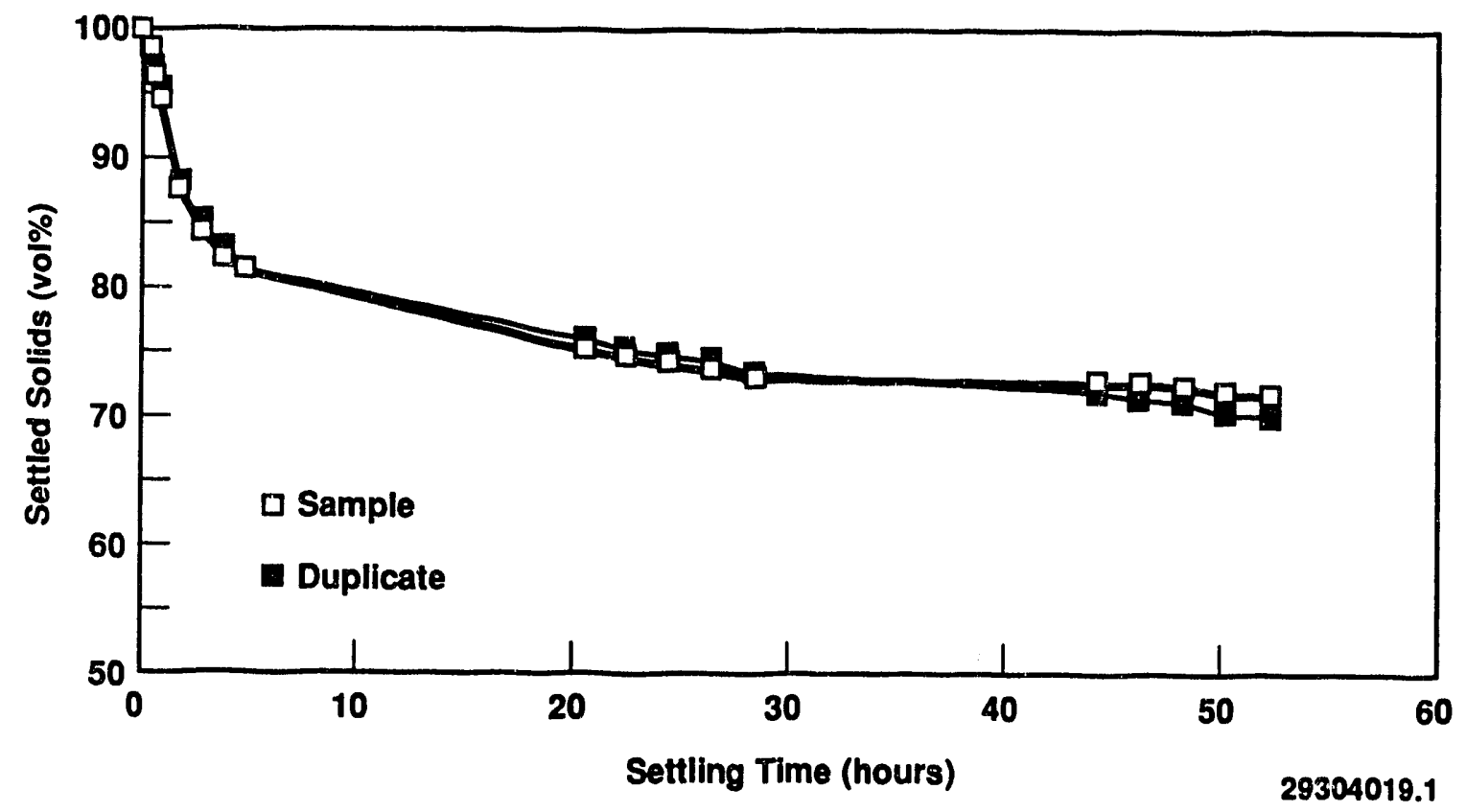


Table 5-8. Water Digestion Chemical Composite Data--ICP Average Values.

\begin{tabular}{|l|r|r|r|}
\hline \multicolumn{1}{|c|}{ Analyte } & $\begin{array}{c}\text { Core } 34 \\
(\mu \mathrm{g} / \mathrm{g} \text { sample })\end{array}$ & $\begin{array}{c}\text { Core } 35 \\
(\mu \mathrm{g} / \mathrm{g} \text { sample })\end{array}$ & $\begin{array}{c}\text { Core } 36 \\
(\mu \mathrm{g} / \mathrm{g} \text { sample })\end{array}$ \\
\hline $\mathrm{Al}$ & 315 & 330 & 814 \\
\hline $\mathrm{Ca}$ & 240 & 339 & 385 \\
\hline $\mathrm{Fe}$ & 1,630 & 712 & 1,390 \\
\hline $\mathrm{Na}$ & 105,000 & 60,500 & 108,000 \\
\hline $\mathrm{Ni}$ & 1,000 & 407 & 792 \\
\hline $\mathrm{P}$ & 6,380 & 5,630 & 16,500 \\
\hline $\mathrm{U}$ & 715 & 460 & 4,600 \\
\hline
\end{tabular}

Table 5-9. Acid Digestion Chemical Composite Data--ICP Average Values.

\begin{tabular}{|l|c|c|c|}
\hline Analyte & $\begin{array}{c}\text { Core 34 } \\
(\mu \mathrm{g} / \mathrm{g})\end{array}$ & $\begin{array}{c}\text { Core 35 } \\
(\mu \mathrm{g} / \mathrm{g})\end{array}$ & $\begin{array}{c}\text { Core 36 } \\
(\mu \mathrm{g} / \mathrm{g})\end{array}$ \\
\hline $\mathrm{Al}$ & 23,300 & 44,600 & 5,530 \\
\hline $\mathrm{Ca}$ & 21,700 & 11,500 & 17,000 \\
\hline $\mathrm{Fe}$ & 20,100 & 26,000 & 19,500 \\
\hline $\mathrm{Na}$ & 95,100 & 70,800 & 103,000 \\
\hline $\mathrm{Ni}$ & 17,700 & 11,100 & 10,600 \\
\hline $\mathrm{P}$ & 19,100 & 18,800 & 30,800 \\
\hline $\mathrm{U}$ & 12,100 & 79,200 & 83,900 \\
\hline
\end{tabular}


Table 5-10. Fusion Digestion Chemical Composite Data--ICP Average Values.

\begin{tabular}{|l|c|c|c|}
\hline Analyte & $\begin{array}{c}\text { Core 34 } \\
(\mu \mathrm{g} / \mathrm{g})\end{array}$ & $\begin{array}{c}\text { Core 35 } \\
(\mu \mathrm{g} / \mathrm{g})\end{array}$ & $\begin{array}{c}\text { Core 36 } \\
(\mu \mathrm{g} / \mathrm{g})\end{array}$ \\
\hline $\mathrm{Al}$ & 29,800 & 45,000 & 6,410 \\
\hline $\mathrm{Ca}$ & 28,900 & 15,000 & 20,400 \\
\hline $\mathrm{Fe}$ & 22,800 & 32,400 & 26,000 \\
\hline $\mathrm{Na}$ & 115,000 & 81,600 & 121,000 \\
\hline $\mathrm{Ni}{ }^{*}$ & 30,000 & 19,900 & 12,800 \\
\hline $\mathrm{P}$ & 22,000 & 21,200 & 36,800 \\
\hline $\mathrm{U}$ & 14,400 & 89,700 & 105,000 \\
\hline
\end{tabular}

Tables 5-11, 5-12, and 5-13 provide ICP analyte concentrations as a function of depth, i.e., for the subsegments.

Table 5-11. Tank 241-C-112 Core 34 ICP Analyte Trending (iusion prep on subsegments).

\begin{tabular}{|l|r|r|r|r|r|r|}
\hline \multicolumn{1}{|c|}{ Subsegment } & $\begin{array}{c}\mathrm{Al} \\
(\mu \mathrm{g} / \mathrm{g})\end{array}$ & $\begin{array}{c}\mathrm{Ca} \\
(\mu \mathrm{g} / \mathrm{g})\end{array}$ & $\begin{array}{c}\mathrm{Fe} \\
(\mu \mathrm{g} / \mathrm{g})\end{array}$ & $\begin{array}{c}\mathrm{Na} \\
(\mu \mathrm{g} / \mathrm{g})\end{array}$ & $\begin{array}{c}\mathrm{Ni}{ }^{*} \\
(\mu \mathrm{g} / \mathrm{g})\end{array}$ & $\begin{array}{c}\mathrm{P} \\
(\mu \mathrm{g} / \mathrm{g})\end{array}$ \\
\hline $1 \mathrm{D}$ & 17,600 & 28,200 & 8,500 & 91,000 & 22,700 & 12,800 \\
\hline $2 \mathrm{~B}$ & 32,400 & 21,700 & 14,700 & 89,000 & 22,200 & 11,100 \\
\hline $2 \mathrm{C}$ & 17,300 & 29,900 & 10,200 & 90,000 & 28,200 & 19,700 \\
\hline $2 \mathrm{D}$ & 26,900 & 23,800 & 19,700 & 78,600 & 23,500 & 19,500 \\
\hline $\begin{array}{l}\text { W. Leach } \\
(\text { Core. Comp })\end{array}$ & 315 & 240 & 1,630 & 105,000 & 1,000 & 6,380 \\
\hline \begin{tabular}{l} 
D. Liquid \\
\hline
\end{tabular} & $<\mathrm{DL}$ & $<\mathrm{DL}$ & 1,200 & 85,700 & 790 & 3,800 \\
\hline
\end{tabular}

*Ni concentrations are potentially biased high. Values are derived from ICP fusion performed in a $\mathrm{Ni}$ crucible. However, in each case the blank value was an order of magnitude (or greater) less than the measurement. The fusion values are comparable with acid digestion values, where both are available. 
Table 5-12. Tank 241-C-112 Core 35 ICP Analyte Trending (fusion prep on subsegments).

\begin{tabular}{|l|r|r|r|r|r|r|}
\hline \multicolumn{1}{|c|}{ Subsegment } & $\begin{array}{c}\mathrm{Al} \\
(\mu \mathrm{g} / \mathrm{g})\end{array}$ & $\begin{array}{c}\mathrm{Ca} \\
(\mu \mathrm{g} / \mathrm{g})\end{array}$ & $\begin{array}{c}\mathrm{Fe} \\
(\mu \mathrm{g} / \mathrm{g})\end{array}$ & $\begin{array}{c}\mathrm{Na} \\
(\mu \mathrm{g} / \mathrm{g})\end{array}$ & $\begin{array}{c}\mathrm{Ni}^{*} \\
(\mu \mathrm{g} / \mathrm{g})\end{array}$ & $\begin{array}{c}\mathrm{P} \\
(\mu \mathrm{g} / \mathrm{g})\end{array}$ \\
\hline 20 & 45,000 & 15,000 & 32,400 & 81,600 & 19,900 & 22,2000 \\
\hline $\begin{array}{l}\text { W. Leach } \\
\text { (Core Comp.) }\end{array}$ & 330 & 339 & 712 & 60,500 & 407 & 5,630 \\
\hline D. Liquid & $\mathrm{CDL}$ & 410 & 750 & 69,900 & 440 & 3,950 \\
\hline
\end{tabular}

Table 5-13. Tank 241-C-112 Core 36 ICP Analyte Trending (fusion prep on subsegments).

\begin{tabular}{|l|r|r|r|r|r|r|}
\hline \multicolumn{1}{|c|}{ Subsegment } & $\begin{array}{c}\mathrm{A} 1 \\
(\mu \mathrm{g} / \mathrm{g})\end{array}$ & $\begin{array}{c}\mathrm{Ca} \\
(\mu \mathrm{g} / \mathrm{g})\end{array}$ & $\begin{array}{c}\mathrm{Fe} \\
(\mu \mathrm{g} / \mathrm{g})\end{array}$ & $\begin{array}{c}\mathrm{Na} \\
(\mu \mathrm{g} / \mathrm{g})\end{array}$ & $\begin{array}{c}\mathrm{Ni}^{*} \\
(\mu \mathrm{g} / \mathrm{g})\end{array}$ & $\begin{array}{c}\mathrm{P} \\
(\mu \mathrm{g} / \mathrm{g})\end{array}$ \\
\hline $1 \mathrm{C}$ & 14,700 & 28,900 & 36,000 & 81,400 & 21,800 & 19,300 \\
\hline $1 \mathrm{D}$ & 4,000 & 28,600 & 7,500 & 81,700 & 23,000 & 19,300 \\
\hline $2 \mathrm{~A}$ & 2,900 & 21,400 & 11,300 & 91,800 & 11,000 & 21,200 \\
\hline $2 \mathrm{~B}$ & 3,100 & 8,900 & 8,900 & 90,600 & 4,800 & 25,200 \\
\hline $2 \mathrm{C}$ & 2,100 & 3,000 & 15,100 & 106,000 & 1,000 & 33,600 \\
\hline 20 & 3,000 & 2,100 & 31,200 & 105,100 & 900 & 29,900 \\
\hline $\begin{array}{l}\text { W. Leach } \\
\text { (Core Comp. })\end{array}$ & 814 & 385 & 1,390 & 108,000 & 792 & 16,500 \\
\hline \begin{tabular}{l} 
D. Liquid \\
\hline
\end{tabular} & None & None & None & None & None & None \\
\hline
\end{tabular}

${ }^{*} \mathrm{Ni}$ concentrations are potentially biased high. Values are derived from ICP fusion performed in a $\mathrm{Ni}$ crucible. However, in each case the blank value was an order of magnitude (or greater) less than the measurement. The fusion values are comparable with acid digestion values, where both are available. 


\subsubsection{Core 34}

The ICP assays for the water leach of the core composite and drainable liquid samples were found to be quite similar. Because the drainable liquid is in equilibrium with the solids and the water leach is done at a 100:1 dilution, the similarity is unexpected. This similarity suggests that some soluble compounds have crystallized from the drainable liquid in the solids in addition to the insoluble materials. The water leach of drainable liquir: samples were compared and used to determine RPDs for the analytes. RPDs were very close for all major analytes, within 2.5 percent.

The acid digestion assay for the drainable liquid gives results similar to those obtained from the core composite water leach. This treatment was done on a liquid sample to solubilize any particles suspended in the sample not removed b: filtration. The major elements found were sodium, phosphorus, iron, uranium, nickel, potassium, and calcium. A full quality control suite was performed on the drainable liquid; the percent recovery for spiked samples and controls were excellent in each case (all recoveries were greater than 92.6 percent). On the solid samples, spike concentrations for iron, sodium, and nickel were insufficient for quantitation (i.e., the concentration of these analytes in the sample was too high for the spike to be detected). Results from the subsegments and core composites correlate reasonably well with the fusion results. RPDs are good (most are within 20 percent), except for calcium, iron, manganese, and zinc. The calcium anomaly is believed to be the result of a high system blank. The iron, manganese, and zinc RPDs are outside the typical 20 percent precision criteria. This behavior is demonstrated throughout the acid digestion analyses and was not unexpected. Both the In Farm simulant matrix and homogenization samples were highly resistant to acid dissolution, and the samples were expected to show similar behavior. The ICP homogenization test results showed no significant difference between the top and bottom samples of subsegments $2 \mathrm{C}$ and $2 \mathrm{D}$, respectively. However, high RPDs for iron, manganese, zinc, and aluminum for each segment sample indicate the possibility of heterogeneity due to a crystalline or particle inclusion.

The RPDs for the fusinn ICP assay were found to be generally good for the subsegment major analytes, routinely within 20 percent. However, there was not enough sample to perform a duplicate measurement on the core composite. The fusion results correlate reasonably well with the acid digestion assay, withir, 30 percent for major analytes. This difference between acid and fusion digestion ICP results further indicates the high insolubility of the waste. $\therefore$ high iron process blank was found in this sample, and its source is undetermined.

\section{3 .3 Core 35}

The ICP assays for the direct drainable liquid and acid digestion of the drainable liquid samples were found to be almost identical and quite similar to the water leach of the core composite. RPDs were very good for all major analytes (within 20 percent). 
The acid digestion assay for the drainable liquid gives results similar to those obtained from the core composite water leach. A full quality control suite was performed on the drainable liquid percent recovery for spiked samples, and controls were excellent in each case (above 90 percent for major analytes). The predominant elements found were sodium, phosphorus, iron, uranium, nickel, potassium, and calcium. On the solid samples, spike concentrations for iron, sodium, and nickel were again insufficient for quantitation. RPDs were generally higher than Core 34 , but within 20 percent, except for calcium, iron, and low concentration analytes near the detection limit in the $5 x$ dilution run (the sample was diluted to five times its original volume). Concentrations of 8 to 9 percent uranium, 4 to 5 percent aluminum, and 3 percent iron make accurate inter-element correction for matrix interferences difficult; thus, the high concentration levels of many "unlikely" analytes (such as lanthanum, neodymium, and thallium) are probably the result of inadequate interelement correction. RPDs for most analytes significantly above the quantitation limit were within the duplicate precision criteria of 20 percent, except for aluminum, uranium, and plutonium.

Duplicate analyses for this assay were unusual--nearly all analytes found in the duplicate are 15 to 20 percent lower than the original. The exception in this case is aluminum, which was 30 percent higher. This behavior suggests that the poor RPDs are the result of an aluminum compound inclusion. The homogenization test showed no significant difference for subsegment $2 D$ top and bottom. The RPDs were acceptable; consequently, the homogenization of the samples was considered adequate. The homogenization test values compared well with the core composite results. Some small silicon inhomogeneity was observed.

The fusion assay appears to improve quantitation for aluminum and silicon. Results for analytes that require significant uranium correction and have low concentration should be considered qualitative (chromium, calcium, titanium, barium, lanthanum). RPDs for major analytes are good (within 15 percent).

\subsubsection{Core 36}

There was no drainable liquid associated with these samples. Water leach RPDs of the core composites were found to be poor (generally above 25 percent). This behavior is attributed to differences in particle size and solubility in the aliquots used to make the composite.

The acid digestion values for the core composite correlate well with the fusion results. RPDs on $1 x$ and $5 x$ dilutions are very good except for calcium and analytes near the detection limit in the $5 x$ dilution run (potassium, lanthanum, neodymium, thallium, and vanadium). RPDs for all analytes that are above the quantitation limit were within the 20 percent process control criteria. Percent recovery for spiked samples and controls was good except for those analytes for which the spike was less than 25 percent of the measured sample concentration. Digestion spike concentrations for aluminum, calcium, iron, manganese, sodium, nickel, and uranium were insufficient for percent recovery quantitation. As previously noted, selenium demonstrates a low bias ( 50 percent) for both spiked samples and controls. The homogenization tests on subsegmerits $1 C$, top and bottom, and 20, top and bottom, showed no significant variation within the subsegment (<10\% RPD). 
However, a large variation is observed between the two subsegments. This behavior was expected from the process history of the tank (e.g., the waste heel that remained prior to adding scavenged waste). Based on sample RPDs, the homogenization of the samples appears adequate.

The RPDs for the fusion ICP assay were found to be generally good for the subsegments and core composite major analytes, each within 20 percent. RPD for iron is good, contrasted with poor RPD for iron in the acid assay. This also suggests a minor sample inhomogeneity.

\subsection{ANALYTICAL RESULTS--ION CHROMATOGRAPHY}

\subsubsection{Ion Chromatography Assays--General Comments}

IC analyses were performed on water-leached samples of the subsegments, core composites, and diluted samples of the drainable liquid (where applicable). Matrix components in some of the samples were found to affect detector performance reversibly during the analysis for free cyanide; thus, a modification to the procedure using pulsed electrode cleaning between sample injections was incorporated to overcome that effect. In addition, the free cyanide assay produced much higher results than those anticipated from the simulant studies. No spike or control standard was used for the free cyanide analysis; therefore, these results may not be representative of the free cyanide in the samples. Quantitation for fluoride (and possibly chloride) was compromised by a co-eluting matrix interference, probably organics of some type. This supposition is supported by the TOC results from the water leach samples. The TOC values, although not high, are large enough to potentially interfere with fluoride and chloride detection. Further information regarding the IC analytes can be found in the full data packages (HASM 1993).

Table 5-14 shows the concentration of IC analytes for each core composite sample. Tables 5-15, 5-16, and 5-17 provide IC analyte concentrations as a function of depth. Tables 5-18, 5-19, and 5-20 provide additional information on other anions as a function of depth. These anions were not determined by the IC method. Reported $\mathrm{pH}$ values for the subsegments and core composites are for 1:100 diluted samples; therefore, only the $\mathrm{pH}$ measurement of the drainable liquids (direct pH measurements) are meaningful. The TOC and total inorganic carbon (TIC) assays are not considered capable of measuring the total cyanide in the waste because they depend on acid dissolutions to perform the analyses.

\subsubsection{Core 34}

Fluoride spike recovery in the core composite was 50 percent; the poor recovery was attributed to matrix interference. All other spike recoveries (where applicable) ranged between 87 and 139 percent, indicating some minor matrix interferences (generally biased high). Control standard recoveries ranged from 87 to 112 percent, indicating that the analys is was in control at the time of the assays. The drainable liquid results are similar to the core composite and subsegment water leach results. This suggests a liquid in saturated equilibrium with the solid core material. RPDs were within 15 percent for a!! IC anions. 
Table 5-14. Ion Chromatography--Composite Data Results (water leach).

\begin{tabular}{|l|r|r|r|}
\hline \multicolumn{1}{|c|}{ Analyte } & $\begin{array}{c}\text { Core 34 } \\
(\mu \mathrm{g} / \mathrm{g})\end{array}$ & $\begin{array}{c}\text { Core 35 } \\
(\mu \mathrm{g} / \mathrm{g})\end{array}$ & \multicolumn{1}{c|}{$\begin{array}{c}\text { Core } 36 \\
(\mu \mathrm{g} / \mathrm{g})\end{array}$} \\
\hline $\mathrm{NO}_{2}^{-}$ & 62,000 & 34,500 & 52,500 \\
\hline $\mathrm{NO}_{3}^{-}$ & 80,000 & 43,500 & 71,500 \\
\hline $\mathrm{PO}_{4}^{3-}$ & 19,100 & 17,850 & 49,500 \\
\hline $\mathrm{SO}_{4}^{2-}$ & 15,600 & 8,600 & 13,700 \\
\hline $\mathrm{Cl}^{-}$ & 1,300 & 750 & 1,050 \\
\hline $\mathrm{F}^{-}$ & 1,000 & 300 & 450 \\
\hline Free CN $^{-}$ & 2,050 & 780 & 1,300 \\
\hline Total Carbon $^{1}$ & 11,700 & 6,100 & 7,000 \\
\hline TOC $^{1}$ & 3,100 & 1,200 & 3,100 \\
\hline TIC $^{1}$ & 8,600 & 4,900 & 4,000 \\
\hline Total Cyanide & 9,700 & $\mathrm{NM}$ & 7,100 \\
\hline
\end{tabular}

${ }^{1}$ Total Carbon, TOC, and TIC are not IC analyses, but are considered anions (TOC + TIC = Total carbon). Thus, it seems appropriate to include them with this table.

${ }^{2}$ Total Cyanide is not an IC anion. Presently it is a developmental assay; however, the total cyanide assay is important in interpreting the data.

$I C=$ Ion chromotography.

$N M=$ No measurement.

TIC = Total inorganic carbon.

TOC = Total organic carbon.

Note: All IC results are obtained from a water leach preparation.

Table 5-15. Tank 241-C-112 Core 34 IC Analyte Trending.

\begin{tabular}{|c|c|c|c|c|c|c|}
\hline Subsegment & $\begin{array}{c}\mathrm{NO}_{2}{ }^{-} \\
(\mu \mathrm{g} / \mathrm{g})\end{array}$ & $\begin{array}{c}\mathrm{NO}_{3}{ }^{-} \\
(\mu \mathrm{g} / \mathrm{g})\end{array}$ & $\begin{array}{c}\mathrm{PO}_{4}^{3-} \\
(\mu \mathrm{g} / \mathrm{g}) \\
\end{array}$ & $\begin{array}{l}\mathrm{SO}_{4}{ }^{2-} \\
\left(\mu \mathrm{g}^{-} / \mathrm{g}\right)\end{array}$ & $\begin{array}{c}\mathrm{Cl}^{\circ} \\
(\mu \mathrm{g} / \mathrm{g}) \\
\end{array}$ & $\begin{array}{c}F^{-} \\
(\mu \mathrm{g} / \mathrm{g}) \\
\end{array}$ \\
\hline 10 & 60,000 & 79,000 & 11,650 & 14,400 & 1,100 & 1,000 \\
\hline $2 B$ & 53,500 & 69,500 & 12,100 & 13,050 & 1,000 & 900 \\
\hline $2 C$ & 48,500 & 64,500 & 11,500 & 11,750 & 900 & 900 \\
\hline 20 & 45,500 & 59,500 & 17,500 & 11,150 & 850 & 950 \\
\hline $\begin{array}{l}\text { W. Leach } \\
\text { (Core Comp.) }\end{array}$ & 62,000 & 80,000 & 19,100 & 15,600 & 1,300 & 1,000 \\
\hline D. Liquid & 55,000 & 72,000 & 11,250 & 11,650 & 1,000 & 600 \\
\hline
\end{tabular}


Table 5-16. Tank 241-C-112 Core 35 IC Analyte Trending.

\begin{tabular}{|l|c|c|c|r|r|r|}
\hline \multicolumn{1}{|c|}{ Subsegment } & $\begin{array}{c}\mathrm{NO}_{3}^{-} \\
(\mu \mathrm{g} / \mathrm{g})\end{array}$ & $\begin{array}{c}\mathrm{NO}_{3}^{-} \\
(\mu \mathrm{g} / \mathrm{g})\end{array}$ & $\begin{array}{c}\mathrm{PO}_{4}{ }^{3-} \\
(\mu \mathrm{g} / \mathrm{g})\end{array}$ & $\begin{array}{r}\mathrm{SO}_{4}{ }^{2-} \\
(\mu \mathrm{g} / \mathrm{g})\end{array}$ & $\begin{array}{r}\mathrm{Cl}^{-} \\
(\mu \mathrm{g} / \mathrm{g})\end{array}$ & $\begin{array}{r}\mathrm{F}^{-} \\
(\mu \mathrm{g} / \mathrm{g})\end{array}$ \\
\hline $2 \mathrm{D}$ & 34,500 & 43,500 & 17,800 & 8,600 & 850 & 300 \\
\hline D. Liquid & 46,000 & 58,500 & 12,900 & 10,900 & 900 & 300 \\
\hline
\end{tabular}

Table 5-17. Tank 241-C-112 Core 36 IC Analyte Trending.

\begin{tabular}{|l|r|r|r|r|r|r|}
\hline \multicolumn{1}{|c|}{ Subsegment } & $\begin{array}{c}\mathrm{NO}_{3}^{-} \\
(\mu \mathrm{g} / \mathrm{g})\end{array}$ & $\begin{array}{c}\mathrm{NO}_{3}^{-} \\
(\mu \mathrm{g} / \mathrm{g})\end{array}$ & $\begin{array}{c}\mathrm{PO}_{4}^{3-} \\
(\mu \mathrm{g} / \mathrm{g})\end{array}$ & $\begin{array}{c}\mathrm{SO}_{4}^{2-} \\
(\mu \mathrm{g} / \mathrm{g})\end{array}$ & $\begin{array}{c}\mathrm{Cl}^{-} \\
(\mu \mathrm{g} / \mathrm{g})\end{array}$ & $\begin{array}{r}\mathrm{F}^{-} \\
(\mu \mathrm{g} / \mathrm{g})\end{array}$ \\
\hline $1 \mathrm{C}$ & 48,000 & 62,000 & 16,600 & 12,050 & 900 & 450 \\
\hline $1 \mathrm{D}$ & 51,000 & 66,500 & 17,800 & 13,000 & 1,000 & 500 \\
\hline $2 \mathrm{~A}$ & 48,500 & 66,000 & 22,850 & 12,400 & 900 & 500 \\
\hline $2 \mathrm{C}$ & 30,000 & 42,500 & 20,400 & 8,050 & 600 & 400 \\
\hline $2 \mathrm{D}$ & 32,000 & 46,000 & 40,500 & 8,600 & 650 & 400 \\
\hline $\begin{array}{l}\text { W. Leach } \\
\text { (Core Comp.) }\end{array}$ & 35,000 & 51,000 & 55,000 & 9,500 & 700 & 1,150 \\
\hline D. Liquid & None & None & None & None & None & None \\
\hline
\end{tabular}

Note: All IC results are obtained from a water leach preparation.

Table 5-18. Tank 241-C-112 Core 34 Misc. Analyte Trending.

\begin{tabular}{|l|c|c|r|r|r|}
\hline \multicolumn{1}{|c|}{ Subsegment } & $\begin{array}{c}\text { TIC } \\
(\mu \mathrm{g} / \mathrm{g})\end{array}$ & $\begin{array}{c}\text { TOC } \\
(\mu \mathrm{g} / \mathrm{g})\end{array}$ & $\begin{array}{c}\text { Free } \mathrm{CN}^{-} \\
(\mu \mathrm{g} / \mathrm{g})\end{array}$ & $\begin{array}{c}\text { Wt\% Total } \\
\text { Carbon }\end{array}$ & $\mathrm{pH}$ \\
\hline $1 \mathrm{D}$ & 7,700 & 4,900 & 1,900 & 1.3 & 9.77 \\
\hline $2 \mathrm{~B}$ & 5,400 & 3,000 & 1,600 & 0.8 & 9.89 \\
\hline $2 \mathrm{C}$ & 5,200 & 3,100 & 1,400 & 0.8 & 9.31 \\
\hline 2D & 6,600 & 4,000 & 1,200 & 1.1 & 9.72 \\
\hline $\begin{array}{l}\text { W. Leach } \\
\text { (Core Comp.) }\end{array}$ & 8,600 & 3,100 & 2,050 & 1.2 & 10.33 \\
\hline \begin{tabular}{l} 
D. Liquid \\
\hline
\end{tabular} & 5,600 & 2,000 & 1,600 & 0.7 & 10.30 \\
\hline
\end{tabular}


Table 5-19. Tank 241-C-112 Core 35 Misc. Analyte Trending.

\begin{tabular}{|l|c|c|c|r|r|}
\hline \multicolumn{1}{|c|}{ Subsegment } & $\begin{array}{c}\text { TIC } \\
(\mu \mathrm{g} / \mathrm{g})\end{array}$ & $\begin{array}{c}\text { TOC } \\
(\mu \mathrm{g} / \mathrm{g})\end{array}$ & $\begin{array}{c}\text { Free } \mathrm{CN}^{-} \\
(\mu \mathrm{g} / \mathrm{g})\end{array}$ & $\begin{array}{c}\text { Wt\% Total } \\
\text { Carbon }\end{array}$ & \multicolumn{1}{c|}{$\mathrm{pH}$} \\
\hline $2 \mathrm{D}$ & 3,700 & 2,500 & 800 & 0.6 & 9.77 \\
\hline $\begin{array}{l}\text { W. Leach } \\
\text { (Core Comp.) }\end{array}$ & 4,900 & 1,200 & 800 & 0.6 & 9.77 \\
\hline D. Liquid & 4,700 & 1,400 & 1,000 & 0.6 & 10.47 \\
\hline
\end{tabular}

Table 5-20. Tank 241-C-112 Core 36 Misc. Analyte Trending.

\begin{tabular}{|l|c|c|r|r|r|}
\hline \multicolumn{1}{|c|}{ Subsegment } & $\begin{array}{c}\text { TIC } \\
(\mu \mathrm{g} / \mathrm{g})\end{array}$ & $\begin{array}{c}\text { TOC } \\
(\mu \mathrm{g} / \mathrm{g})\end{array}$ & $\begin{array}{c}\text { Free } \mathrm{CN}^{-} \\
(\mu \mathrm{g} / \mathrm{g})\end{array}$ & $\begin{array}{c}\text { Wt\% Total } \\
\text { Carbon }\end{array}$ & $\mathrm{pH}$ \\
\hline $1 \mathrm{C}$ & 4,000 & 8,200 & 1,100 & 1.1 & 9.12 \\
\hline 10 & 5,400 & 4,900 & 1,200 & 1.0 & 9.57 \\
\hline $2 \mathrm{~A}$ & 4,500 & 3,900 & 1,200 & 0.9 & 9.54 \\
\hline $2 \mathrm{~B}$ & 2,500 & 2,700 & 700 & 0.5 & 8.92 \\
\hline $2 \mathrm{C}$ & 3,400 & 2,900 & 800 & 0.6 & 9.29 \\
\hline $2 \mathrm{D}$ & 2,900 & 2,300 & 900 & 0.5 & 9.36 \\
\hline $\begin{array}{l}\text { W. Leach } \\
\text { (Core Comp.) }\end{array}$ & 5,300 & 1,400 & 1,300 & & 9.2 \\
\hline \begin{tabular}{l} 
D. Liquid \\
\hline
\end{tabular} & None & None & None & None & None \\
\hline
\end{tabular}

\section{4 .3 Core 35}

IC analyses were performed on drainable liquid and core composite water leach samples. Samples exhibited characteristic poor spike recovery for fluoride (40 percent). Spike recoveries for the other anions indicate minimal matrix interferences. The water leach sample spike recoveries for $\mathrm{NO}_{3}{ }^{-}, \mathrm{PO}_{4}{ }^{3-}$, and $\mathrm{SO}_{4}{ }^{2-}$ were significantly higher than normal (136 percent, 129 percent, and 122 percent, respectively). This behavior was attributed to sample inhomogeneity by the investigator. Control standard recoveries ranged from 83 percent to 112 percent; chloride showed a recovery of 132 percent. Other chloride spike controls run at the same time showed 96 percent and 92 percent recovery. Analyses were considered in control at the time of the assays. The drainable liquid samples exhibited good RPDs for all anions, within 5 percent. Analyte concentrations in the drainable liquid corresponds with the concentrations in the water leach samples. 


\section{4 .4 Core 36}

IC analyses were performed on subsegment and core composite water leach samples. No drainable liquid was recovered with the Core 36 samples. Subsegment 36-1C water leach samples exhibited characteristic poor spike recovery and RPD for fluoride (37 percent and 22 percent, respectively). Spike recoveries for the other anions ranged from 80 percent to 111 percent, indicating minimal matrix interferences. Control standard recoveries ranged from 91 to 107 percent. The analyses were considered in control. Consistent behavior between subsegments was found for $\mathrm{NO}_{2}^{-}, \mathrm{NO}_{3}^{-}$, and $\mathrm{SO}_{4}{ }^{2-}$, chloride, and free cyanide (i.e., when $\mathrm{NO}_{2}$. is low, free cyanide is low, etc.), possibly indicating a matrix interference for free cyanide from the other anions. Phosphate and fluoride showed significant differences and do not, in general, track the behavior of the other anions. This is possibly associated with an intrinsic sample inhomogeneity relative to these anions or a heterogeneity associated with tank 241-C-112 itself (i.e., a waste heel). The core composite water leach results magnify the effect of the sample inhomogeneity/tank heterogeneity. This poor reproducibility of sample and duplicate is common for inorganic water leach assays on this sample matrix. RPDs are consistently high for all analytes, ranging from 22 to 43 percent.

\subsection{ANALYTICAL RESULTS--RADIOCHEMISTRY}

\subsubsection{Radiochemistry Assays--General Comments}

Analyses appear to be consistent. Total beta measurements calculated using ${ }^{90} \mathrm{Sr}$ detector efficiencies are largely in agreement with the sum of the major beta emitters, ${ }^{90} \mathrm{Sr}$ and ${ }^{137} \mathrm{Cs}$. Similarly, the total alpha values show good agreement with the sum of the neptunium, plutonium, and americium/curium values. The gamma energy analyses results obtained from wet chemistry correlate with the results from the segment gamma scans. Detection of ${ }^{137} \mathrm{Cs}$ and most other radionuclides was observed to increase as a function of sample preparation. This was attributed to the ability of the sample preparation to dissolve the waste ( $\mathrm{KOH}$ fusion dissolves the sample better than acid; acid dissolves the sample better than water). Uranium measurements were obtained from ICP fusion and laser fluorimetry, and show reasonably good agreement between Core 34 and 36 . Core 35 has a large discrepancy between the two measurements, which can be attributed to matrix interferences or differences in sample particle size. Alpha energy analysis and GEA show good agreement for ${ }^{241} \mathrm{Am}$. GEA analytical values are back-corrected to January 1, 1992, to account for decay.

Tables 5-21, 5-22, and 5-23 show the radionuclide concentrations found in the core composite samples. Tables 5-24, 5-25, and 5-26 show fission product concentration and uranium concentrations as a function of depth. 
Table 5-21. Core Composite Fission Products (fusion prep).

\begin{tabular}{|l|c|c|r|r|r|r|}
\hline Core No. & $\begin{array}{c}{ }^{137} \mathrm{Cs} \\
(\mu \mathrm{Ci} / \mathrm{g})\end{array}$ & $\begin{array}{c}{ }^{90} \mathrm{Sr} \\
(\mu \mathrm{Ci} / \mathrm{g})\end{array}$ & $\begin{array}{c}{ }^{154} \mathrm{Eu} \\
(\mu \mathrm{Ci} / \mathrm{g})\end{array}$ & $\begin{array}{c}{ }^{155} \mathrm{Eu} \\
(\mu \mathrm{Ci} / \mathrm{g})\end{array}$ & $\begin{array}{c}{ }^{60} \mathrm{Co} \\
(\mu \mathrm{Ci} / \mathrm{g})\end{array}$ & $\begin{array}{c}\text { Total } \\
\text { Beta } \\
(\mu \mathrm{Ci} / \mathrm{g})\end{array}$ \\
\hline Core 34 & 750 & 3,500 & 1.25 & 1.27 & 0.03 & 7,070 \\
\hline Core 35 & 700 & 3,200 & 2.01 & 2.22 & $2.1 \mathrm{E}-04$ & 7,000 \\
\hline Core 36 & 800 & 510 & 0.156 & ND & 0.006 & 1,700 \\
\hline
\end{tabular}

ND $=$ Not detected.

Table 5-22. Core Composite Uranium.

\begin{tabular}{|l|c|c|c|c|}
\hline Core No. & $\begin{array}{c}U_{1 \mathrm{icp} \text { fysion }}(\mu \mathrm{g} / \mathrm{g}) \\
\text { Core } 34\end{array}$ & $\begin{array}{c}\mathrm{U}_{\mathrm{F} /} \\
(\mu \mathrm{g} / \mathrm{g})\end{array}$ & $\begin{array}{c}238 \mathrm{U} \\
\text { mass fraction }\end{array}$ & $\begin{array}{c}{ }^{235} \mathrm{U} \\
\text { mass } \\
\text { fraction }\end{array}$ \\
\hline Core 35 & 14,400 & 17,700 & 0.993107 & 0.006715 \\
\hline Core 36 & 89,700 & 44,300 & 0.993112 & 0.006761 \\
\hline
\end{tabular}

$\mathrm{FL}=$ Uranium measurement by laser fluorimetry.

Table 5-23. Core Composite Transuranics (fusion preparation).

\begin{tabular}{|l|c|c|c|c|c|r|}
\hline Core No. & $\begin{array}{c}{ }^{237} \mathrm{~Np} \\
(\mu \mathrm{Ci} / \mathrm{g})\end{array}$ & $\begin{array}{c}{ }^{238} \mathrm{Pu} \\
(\mu \mathrm{Ci} / \mathrm{g})\end{array}$ & $\begin{array}{c}{ }^{239 / 240} \mathrm{Pu} \\
(\mu \mathrm{Ci} / \mathrm{g})\end{array}$ & $\begin{array}{c}{ }^{249} \mathrm{Am}_{\mathrm{GEA}} \\
(\mu \mathrm{Ci} / \mathrm{g})\end{array}$ & $\begin{array}{c}{ }^{241} \mathrm{Am}_{\mathrm{AEE}} \\
(\mu \mathrm{Ci} / \mathrm{g})\end{array}$ & $\begin{array}{c}\text { Tota } \alpha \\
(\mu \mathrm{Ci} / \mathrm{g})\end{array}$ \\
\hline Core 34 & $6.62 \mathrm{E}-04$ & 0.0137 & 0.155 & 0.76 & 0.613 & 0.95 \\
\hline Core 35 & $1.20 \mathrm{E}-03$ & 0.0137 & 0.151 & 1.05 & 0.763 & 1.18 \\
\hline Core 36 & $4.09 \mathrm{E}-04$ & 0.0033 & 0.0593 & ND & 0.0612 & 0.17 \\
\hline
\end{tabular}

$A E A=$ Measurement by alpha energy analysis.

$\mathrm{GEA}=$ Measurement by gamma energy analysis.

$N D=$ Not detected. 
Table 5-24. Tank 241-C-112 Core 34 Radionuclide Trending (fusion preparation).

\begin{tabular}{|l|c|c|c|}
\hline \multicolumn{1}{|c|}{ Subsegment } & $\begin{array}{c}{ }^{137} \mathrm{Cs} \\
(\mu \mathrm{Ci} / \mathrm{g})\end{array}$ & $\begin{array}{c}{ }^{90} \mathrm{Sr} \\
(\mu \mathrm{Ci} / \mathrm{g})\end{array}$ & $\begin{array}{c}\mathrm{U}_{\mathrm{ICp}} \\
(\mu \mathrm{g} / \mathrm{g})\end{array}$ \\
\hline $\mathrm{ID}$ & 240 & 1,300 & None \\
\hline $2 \mathrm{~B}$ & 610 & 4,900 & 3,000 \\
\hline $2 \mathrm{C}$ & 800 & 1,100 & 5,700 \\
\hline $2 \mathrm{D}$ & 510 & 2,500 & 20,000 \\
\hline W. Leach (Core Comp. $)$ & 6.16 & $27.88^{\star}$ & 715 \\
\hline $\begin{array}{l}\text { Acid Digestion } \\
(D \text { Liquid) }\end{array}$ & 0.04 & 0.35 & 1,130 \\
\hline
\end{tabular}

*Value from total beta analysis.

Table 5-25. Tank 241-C-112 Core 35 Radionuclide Trending (fusion preparation).

\begin{tabular}{|l|c|c|c|}
\hline \multicolumn{1}{|c|}{ Subsegment } & $\begin{array}{c}{ }^{137} \mathrm{Cs} \\
(\mu \mathrm{Ci} / \mathrm{g})\end{array}$ & $\begin{array}{c}{ }^{90} \mathrm{Sr} \\
(\mu \mathrm{Ci} / \mathrm{g})\end{array}$ & $\begin{array}{c}\mathrm{U}_{1 \mathrm{CP}} \\
(\mu \mathrm{g} / \mathrm{g})\end{array}$ \\
\hline $2 \mathrm{D}$ & 700 & 3210 & 89,700 \\
\hline $\begin{array}{l}\text { W. Leach } \\
\text { (Core Comp.) }\end{array}$ & 5.2 & N.M. & 460 \\
\hline $\begin{array}{l}\text { Acid Digestion } \\
(\mathrm{D} \text { Liquid) }\end{array}$ & 0.007 & 0.23 & 928 \\
\hline
\end{tabular}

Drainable liquids are measured directly.

Table 5-26. Tank 241-C-112 Core 36 Radionuclide Trending (fusion preparation).

\begin{tabular}{|l|c|c|c|}
\hline \multicolumn{1}{|c|}{ Subsegment } & $\begin{array}{c}{ }^{137} \mathrm{Cs} \\
(\mu \mathrm{Ci} / \mathrm{g})\end{array}$ & $\begin{array}{c}{ }^{90} \mathrm{Sr} \\
(\mu \mathrm{Ci} / \mathrm{g})\end{array}$ & $\begin{array}{c}\mathrm{U}_{\mathrm{ICP}} \\
(\mu \mathrm{g} / \mathrm{g})\end{array}$ \\
\hline $1 \mathrm{C}$ & 560 & 1,900 & 4,400 \\
\hline $1 \mathrm{D}$ & 1,200 & 15 & 3,100 \\
\hline $2 \mathrm{~A}$ & 880 & 20 & 40,000 \\
\hline 2B & 530 & 70 & 170,000 \\
\hline 2C & 100 & 140 & 110,000 \\
\hline W. Leach (Core Comp.) & N.M. & $11.8 *$ & 4,600 \\
\hline D. Liquid & None & None & None \\
\hline
\end{tabular}

*value from total beta analysis. 


\subsubsection{Core 34 Radiochemistry}

Mass fractions for isotopic plutonium are ${ }^{239} \mathrm{Pu}=0.93936 ;{ }^{240} \mathrm{Pu}=0.0579$. The concentration of ${ }^{238} \mathrm{U}$ was too high to determine ${ }^{238} \mathrm{Pu}$ by mass spectrometry; thus, alpha energy analysis of the separated plutonium fraction was used to determine ${ }^{238} \mathrm{Pu}$. Process sample blanks show small levels of contamination for selected isotopes. However, the contamination is negligible when compared to the activity in the solid samples. Radiochemical recoveries for specific analytes of interest for all samples are as follows: ${ }^{90} \mathrm{Sr}$ (92 to 105 percent), uranium (101 percent), ${ }^{237} \mathrm{~Np}$ (94 percent), plutonium (92 percent), and americium/curium (103 percent).

\subsubsection{Core 35 Radiochemistry}

Uranium measurements from laser fluorimetry had an average chemical recovery of 104 percent. The neptunium, plutonium, and americium fractions were separated and counted. Plutonium concentration was too low to perform isotopic analysis by mass spectroscopy. Alpha energy analyses were used to determine isotopic plutonium ratios and other alpha emitter concentrations. Problems were encountered in performing the plutonium analys is of the drainable liquid; erratic results and behavior of the sample during analysis was observed.

\subsubsection{Core 36 Radiochemistry}

Mass fractions for isotopic plutonium are ${ }^{239} \mathrm{Pu}=0.95887$;

${ }^{240} \mathrm{Pu}=0.03943$. The concentration of ${ }^{238} \mathrm{U}$ was too high to determine ${ }^{238} \mathrm{Pu}$ by mass spectrometry; thus, alpha energy analysis of the separated plutonium fraction was used to determine ${ }^{238} \mathrm{Pu}$. Process sample blanks show small levels of contamination for selected isotopes, similar to Core 34 . The contamination is negligible when compared to the activity in the solid samples. These levels are significant for tritium and ${ }^{60} \mathrm{Co}$ measured by GEA; however, neither of those analytes contribute substantially to the radiological content of the waste. Radiochemical recoveries for specific analytes of interest for reagent or simulated matrix standards are as follows: ${ }^{90} \mathrm{Sr}$ (101 percent), uranium (107 percent), ${ }^{237} \mathrm{~Np}$ (89 percent), plutonium (96 plutonium), and americium (100 percent).

\subsection{ANALYTICAL RESULTS--ENERGETICS}

Scanning TGA and DSC were performed on subsegment and core composite material obtained from tank 241-C-112. These two thermal analys is techniques are useful in determining the thermal stability or reactivity of a material. In DSC analysis, heat flow over and above the usual heat capacity of the substance is measured while the substance is exposed to a linear increase in temperature, i.e., $d T / d t=$ Constant (where $T=$ temperature, and $t=t i m e$ ). While the substance is being heated, air is passed over the waste material to remove any gases being released. The onset temperature for an endothermic or exothermic event on a DSC is determined graphically. The endpoints of the event are determined and a line is drawn between them to establish a base. 
A line tangent to the initial side of the event is drawn until it intersects the base. From that point of intersection, a vertical line is constructed to the temperature scale at the bottom of the DSC curve; that temperature is the onset temperature of the event.

TGA measures the mass of a sample while the temperature of the sample is increased at a constant rate. Again, $d T / d t$ is constant; the $X$-axis is representative of the running time of the analysis as well as the temperature increase of the sample during analysis. The $Y$-axis represents the weight percent of the sample and is effectively unitless. As with the DSC, air is passed over the sample during heating. Any decrease in the weight percent of the sample represents a loss of gaseous matter from the sample either through evaporation or through a reaction that forms gas phase products.

DSC is often used to measure thermal decomposition temperatures, heats of reaction, reaction temperatures, melting points, and solid-solid transition temperatures. TGA is used to measure thermal decomposition temperatures, water content, and reaction temperatures. The two methods often provide complementary information.

\subsubsection{Remarks on the Interpretation of Differential Scanning Calorimetry/Thermogravimetric Analysis Data}

Tables 5-27 and 5-28 summarize the results of the thermal analyses performed: There are three significant features seen on both the DSC and TGA plots. Several minor endotherms appear on the DSC, but only endotherms greater than $20 \mathrm{~J} / \mathrm{g}$ were considered as significant features of the plot. The values presented in the tables do not exactly match the values recorded on the DSC and TGA plots. This is because interpreting these semi-quantitative analyses requires considerable experience and judgement on the part of the analyst. The values presented represent the best summary evaluation of the data (Tingey 1993). Although the temperature ranges observed for the various transitions in the DSC and TGA assays do not exactly match, the weight losses and thermal events in the observed transitions are considered related and usually in the same vicinity.

There is a concern regarding the choice of cover gas affecting the DSC and TGA results. Air was used in the assays instead of an inert gas because that is what the test instructions directed. However, oxygen in the air may contribute to the oxidation of the sample and alter the reaction (Pederson et al. 1993). This condition is not considered representative of the potential reaction conditions in the tank; therefore, future DSC/TGA tests will be performed under an inert cover gas. 
Table 5-27. Thermogravimetric Analysis Results from Tank 241-C-112.

\begin{tabular}{|c|c|c|c|c|}
\hline $\begin{array}{c}\text { Core } \\
\text { Sample }\end{array}$ & $\begin{array}{c}\text { Total Wt\% } \\
\text { loss }\end{array}$ & $\begin{array}{c}\text { Transition } 1 \\
\text { Wt\% loss }\end{array}$ & $\begin{array}{c}\text { Transition } 2 \\
\text { Wt\% loss }\end{array}$ & $\begin{array}{c}\text { Transition } \\
\text { Wt\% loss }\end{array}$ \\
\hline $34-10$ & 20.2 & 6.6 & 13.6 & N.A. \\
\hline $34-2 B$ & 56.8 & 52 & 5.4 & -0.6 \\
\hline $34-2 C$ & 48.7 & 45 & 4.0 & -0.3 \\
\hline $34-20$ & 39.3 & 33 & 6.3 & 0 \\
\hline 34-Comp. & 40.5 & 35 & 6.1 & -0.6 \\
\hline $35-2 D$ & 48.0 & 42 & 6.0 & 0 \\
\hline $36-1 C$ & 54.6 & 46 & 8.9 & -0.3 \\
\hline $36-10$ & 51.8 & 52 & 2.0 & -0.2 \\
\hline $36-2 A$ & 53.7 & 52 & 1.9 & -0.2 \\
\hline $36-2 B$ & 41.0 & 38 & 3.1 & -0.1 \\
\hline $36-2 C$ & 44.8 & 41 & 3.8 & 0 \\
\hline $36-20$ & 50.8 & 47 & 3.5 & 0.3 \\
\hline 36-Comp. & 54.2 & 44 & 2.9 & 0.3 \\
\hline
\end{tabular}


Table 5-28. Differential Scanning Calorimetry Energetics Results from Tank 241-C-112.

\begin{tabular}{|c|c|c|c|c|c|c|c|c|c|}
\hline \multirow{2}{*}{$\begin{array}{c}\text { Core } \\
\text { Sample }\end{array}$} & \multicolumn{3}{|c|}{ Transition 1} & \multicolumn{3}{|c|}{ Transition 2} & \multicolumn{3}{|c|}{ Transition 3} \\
\hline & $\begin{array}{c}\text { Range } \\
\left({ }^{\circ} \mathrm{C}\right)\end{array}$ & $\begin{array}{c}\text { Onset } \\
\left({ }^{\circ} \mathrm{C}\right)\end{array}$ & $\begin{array}{c}\Delta H \\
(\mathrm{~J} / \mathrm{g})\end{array}$ & $\begin{array}{c}\text { Range } \\
\left({ }^{\circ} \mathrm{C}\right)\end{array}$ & $\begin{array}{c}\text { Onset } \\
\left({ }^{\circ} \mathrm{C}\right)\end{array}$ & $\begin{array}{c}\Delta H \\
(\mathrm{~J} / \mathrm{g})\end{array}$ & $\begin{array}{c}\text { Range } \\
\left({ }^{\circ} \mathrm{C}\right)\end{array}$ & $\begin{array}{c}\text { Onset } \\
\left({ }^{\circ} \mathrm{C}\right)\end{array}$ & $\begin{array}{c}\Delta H \\
(\mathrm{~J} / \mathrm{g})\end{array}$ \\
\hline $34-10$ & $58-110$ & 62 & 30 & 206-312 & 215 & 515 & $356-444$ & 375 & -17 \\
\hline $34-2 B$ & $30-240$ & 30 & 847 & $260-300$ & 276 & -12 & $300-400$ & 349 & \\
\hline $34-2 C$ & $30-240$ & 30 & 795 & $260-300$ & 267 & -13 & $300-400$ & 360 & \\
\hline $34-20$ & $33-240$ & 33 & 930 & $260-300$ & 289 & -17 & $300-400$ & 347 & \\
\hline 34-Comp. & $34-240$ & 34 & 734 & $260-300$ & 276 & -11 & $300-400$ & 357 & \\
\hline $35-2 D$ & $34-195$ & 34 & 780 & $225-290$ & 230 & -12 & & & \\
\hline $36-1 C$ & $34-240$ & 34 & 1,070 & $260-300$ & 267 & -11 & $300-380$ & 301 & 31 \\
\hline $36-10$ & $32-230$ & 32 & 1,310 & $260-310$ & 277 & -16 & (a) & NA & \\
\hline $36-2 A$ & $30-230$ & 30 & 1,110 & $277-300$ & 280 & -10 & $300-400$ & 305 & 35 \\
\hline $36-2 B$ & $33-235$ & 30 & 870 & $260-325$ & 298 & -9 & $325-400$ & 330 & 28 \\
\hline $36-2 C$ & $33-240$ & 32 & 830 & (a) & NA & None & $305-407$ & 320 & 36 \\
\hline $36-20$ & $34-172$ & 34 & 1,060 & (a) & NA & None & $300-395$ & 328 & 45 \\
\hline 36-Comp. & $34-172$ & 34 & 880 & $270-325$ & 288 & -19 & (a) & NA & \\
\hline
\end{tabular}

(a) This transition is not quantifiable.

NOTE: To convert from $\mathrm{J}$ to cal, divide by 4.18.

NOTE: Negative $\Delta H$ indicates an exotherm.

$N A=$ Not applicable. 


\subsubsection{General Comments on the Differential Scanning Calorimetry/Thermogravimetric Analysis Behavior of the Samples}

The first transition in each sample is endothermic, begins at the lower temperature limit of the analysis $\left(30^{\circ} \mathrm{C}\right)$, and is essentially complete between $140{ }^{\circ} \mathrm{C}$ and $200^{\circ} \mathrm{C}$. The most likely phenomenon occurring in this region are the release of the bulk and interstitial water in the core sample material. The endotherms exhibited in this region are quite substantial (typically, 700 to $1,200 \mathrm{~J} / \mathrm{g})$. These values are per gram of wet sample; if divided by the mass fraction lost during analysis, they range from 1,400 to $2,600 \mathrm{~J} / \mathrm{g}$ and correspond generally with the heat of vaporization of water $(2,260 \mathrm{~J} / \mathrm{g})$. In addition, the majority of the weight percent change observed in the TGA curve occurs over this same temperature range. The TGA water content corresponds closely (but not exactly) with the water loss observed in a gravimetric weight percent solids determination. Some of this discrepancy is attributable to the time elapsed between the two assays. In some cases, up to two months pass between the gravimetric weight percent solids assay and the TGA measurement. Extended exposure to the ambient hot cell conditions are believed to have dried the sample somewhat in that period of time; thus, some of the water content measurements may be biased low. The warm, dry conditions in the hot cell will remove moisture between the time of the sample assays. However, the results from the two methods are generally in agreement (Core 35 was an anomaly).

Exotherms and additional weight loss are routinely detected between 260 to $300^{\circ} \mathrm{C}$ in all the samples. Similar exotherms and weight changes have been observed in previous thermal analys is studies of $\mathrm{Cs}_{2} \mathrm{NiFe}(\mathrm{CN})_{6}$ (Scheele et al. 1991) and other simulant materials (Bechtold 1992; Jeppson 1993). As reported previously, the dried simulant materials demonstrate much larger. exothermic responses than those observed in tank $241-C-112$ waste. However, the magnitude of the exotherms observed correlates roughly with the predicted exotherms derived from the amount of cyanide present in the waste (refer to Table 5-29 and 5-30), based on the Fauske (1992) determined value of $-3.95 \mathrm{~kJ} / \mathrm{g} \mathrm{Na} \mathrm{NiFe}(\mathrm{CN})_{6}$. The weight losses are attributed to the loss of gaseous reaction products and waters of hydration.

Table 5-29. Tank 241-C-112 Core 34 Energetic Comparison.

\begin{tabular}{|l|r|r|r|r|}
\hline Subsegment & $\begin{array}{c}\text { Wt\% } \\
\text { Total } \\
\text { Cyanide } \\
\text { (dry) }\end{array}$ & $\begin{array}{c}\text { Equivalent Wt\% } \\
\text { Total } \\
\text { Ferrocyanide } \\
\text { (dry) }\end{array}$ & $\begin{array}{c}\text { Theoretical } \\
\text { Heat of Reaction } \\
\text { (cal/g dry waste) }\end{array}$ & $\begin{array}{c}\text { Measured } \\
\text { Heat of Reaction } \\
\text { (cal/g dry } \\
\text { waste) }\end{array}$ \\
\hline $1 D$ & 0.52 & 1.06 & -10.0 & -5.1 \\
\hline $2 B$ & 0.43 & 0.87 & -8.3 & -6.7 \\
\hline $2 C$ & 0.83 & 1.69 & -15.9 & -6.1 \\
\hline $2 D$ & 0.75 & 1.52 & -14.4 & -6.7 \\
\hline Composite & 0.97 & 1.97 & -18.6 & -4.4 \\
\hline
\end{tabular}

NOTE: $1 \mathrm{cal}=4.18 \mathrm{~J}$. 
Table 5-30. Tank 241-C-112 Core 36 Energetic Comparison.

\begin{tabular}{|l|r|r|r|r|}
\hline Subsegment & $\begin{array}{c}\text { Wt\% } \\
\text { Total } \\
\text { Cyanide } \\
\text { (dry) }\end{array}$ & $\begin{array}{c}\text { Equivalent Wt\% } \\
\text { Total } \\
\text { Ferrocyanide } \\
\text { (dry) }\end{array}$ & $\begin{array}{c}\text { Theoretical } \\
\text { Heat of Reaction } \\
\text { (cal/g dry waste) }\end{array}$ & $\begin{array}{c}\text { Measured } \\
\text { Heat of Reaction } \\
\text { (cal/g dry waste) }\end{array}$ \\
\hline IC & NM & NM & NM & -5.8 \\
\hline $1 D$ & 0.72 & 1.46 & -13.8 & -8.0 \\
\hline 2A & 0.92 & 1.87 & -17.7 & -3.7 \\
\hline $2 B$ & 0.75 & 1.52 & -14.4 & No exotherm \\
\hline 2C & 0.40 & 0.81 & -7.7 & No exotherm \\
\hline 2D & 0.56 & 1.14 & -13.6 & -8.6 \\
\hline Composite & 0.71 & 1.44 & &
\end{tabular}

$\mathrm{NM}=$ No measurement.

NOTE: $1 \mathrm{cal}=4.18 \mathrm{~J}$.

There is an observable third transition range, but here the energetic behavior is not readily quantifiable. Initially, Cores 34 and 35 appeared to have some significant exothermic behavior detected in the temperature range between 300 to $440{ }^{\circ} \mathrm{C}$. In the Core 36 materials, the investigator detected no exothermic activity in this temperature range. This difference in behavior was unexpected, especially in light of small, but detectable, cyanide and organic levels in the waste, suggesting the potential for a corresponding exotherm. Further analysis of the DSC results suggests that the observed activity was the consequence of subtracting a rapidly changing baseline measurement from the analytical results. Therefore, it is believed that there is no quantifiable exothermic activity in that temperature range. This interpretation is contrary to previousiy released information. A minor weight gain was sometimes observed in this temperature range, most likely an oxidation of some type.

The properties related to energe's cs are illustrated for each core in Tables 5-31, 5-32, and 5-33. The resists for the samples from 34-1D, 36-2C, and 36-2D indicate that these samples differ in thermal behavior from most of the other samples, further suggesting a difference in waste type. 
Table 5-31. Tank 241-C-112 Core 34 Energetics Trending.

\begin{tabular}{|l|r|r|r|r|r|r|}
\hline Subsegment & $\begin{array}{c}\text { Wt\% } \\
\text { Total } \\
\text { Cyanide } \\
\text { (dry) }\end{array}$ & $\begin{array}{c}\text { Wt\% } \\
\text { Total } \\
\text { Organic } \\
\text { Carbon }\end{array}$ & $\begin{array}{c}\text { Wt\% } \\
\text { Total } \\
\text { Carbon }\end{array}$ & $\begin{array}{c}\text { Wt\% } \\
\text { Water } \\
\text { (Grav.) }\end{array}$ & $\begin{array}{c}\text { Wt\% } \\
\text { Water } \\
\text { (TGA) }\end{array}$ & $\begin{array}{c}\text { Average Heat } \\
\text { of Reaction } \\
\text { (kJ/g dry } \\
\text { waste) }\end{array}$ \\
\hline ID & 0.52 & 0.49 & 1.3 & 45 & 20 & -0.02 \\
\hline 2B & 0.43 & 0.30 & 0.8 & 53 & 57 & -0.03 \\
\hline 2C & 0.83 & 0.31 & 0.8 & 58 & 49 & -0.03 \\
\hline 2D & 0.75 & 0.40 & 1.1 & 52 & 39 & -0.03 \\
\hline Composite & 0.97 & 0.31 & NM & 38 & 41 & -0.02 \\
\hline
\end{tabular}

Table 5-32. Tank 241-C-112 Core 35 Energetics Trending.

\begin{tabular}{|l|c|c|c|c|c|c|}
\hline Subsegment & $\begin{array}{c}\text { Wt\% } \\
\text { Total } \\
\text { Cyanide } \\
\text { (dry) }\end{array}$ & $\begin{array}{c}\text { Wt\% Total } \\
\text { Organic } \\
\text { Carbon }\end{array}$ & $\begin{array}{c}\text { Wt\% } \\
\text { Total } \\
\text { Carbon }\end{array}$ & $\begin{array}{c}\text { Wt\% } \\
\text { Water } \\
\text { (Grav.) }\end{array}$ & $\begin{array}{c}\text { Wt\% } \\
\text { Water } \\
\text { (TGA) }\end{array}$ & $\begin{array}{c}\text { Average Heat of } \\
\text { Reaction } \\
\text { (kJ/g dry waste) }\end{array}$ \\
\hline 2D & NM & 0.25 & 0.6 & 34 & 48 & -0.02 \\
\hline
\end{tabular}

Table 5-33. Tank 241-C-112 Core 36 Energetics Trending.

\begin{tabular}{|l|r|r|r|r|r|r|}
\hline Subsegment & $\begin{array}{c}\text { Wt\% } \\
\text { Total } \\
\text { Cyanide } \\
\text { (dry) }\end{array}$ & $\begin{array}{c}\text { Wt\% } \\
\text { Total } \\
\text { Organic } \\
\text { Carbon }\end{array}$ & $\begin{array}{c}\text { Wt\% } \\
\text { Total } \\
\text { Carbon }\end{array}$ & $\begin{array}{c}\text { Wt\% } \\
\text { Water } \\
\text { (Grav.) }\end{array}$ & $\begin{array}{c}\text { Wt\% } \\
\text { Water } \\
\text { (TGA) }\end{array}$ & $\begin{array}{c}\text { Average Heat of } \\
\text { Reaction } \\
\text { (kJ/g dry waste) }\end{array}$ \\
\hline $1 \mathrm{C}$ & N.M. & 0.82 & 1.1 & 49 & 55 & -0.02 \\
\hline 10 & 0.72 & 0.49 & 1.0 & 58 & 52 & -0.03 \\
\hline $2 \mathrm{~A}$ & 0.92 & 0.39 & 0.9 & 57 & 54 & -0.02 \\
\hline $2 \mathrm{~B}$ & 0.75 & 0.27 & 0.5 & 41 & 41 & -0.02 \\
\hline $2 \mathrm{C}$ & 0.40 & 0.29 & 0.6 & 64 & 45 & No exotherm \\
\hline $2 \mathrm{D}$ & 0.56 & 0.23 & 0.5 & 56 & 51 & No exotherm \\
\hline Composite & 0.71 & 0.14 & 0.7 & 45 & 47 & -0.04 \\
\hline
\end{tabular}

Heats of Reaction are calculated using the TGA wt\% water value.

NOTE: $1 \mathrm{kcal}=4.18 \mathrm{~kJ}$.

The TOC and TIC assays are not considered capable of measuring the total cyanide in the waste because they depend on acid dissolutions to perform the analyses. 


\subsection{ANALYTICAL RESULTS - POTENTIAL WASTE CONSTITUENTS}

\subsubsection{Mass Balances}

A method to aid in ensuring that the data are acceptable is to perform a mass balance on the core composite sample data. This activity functions as a rough quality control check, and also provides insight to some of the properties of the matrix. To do this, the assumption in performing the mass balance is that the anions, cations, and water are all associated in some manner, but the exact chemistry of the association is not considered. Analytes contributing less than 0.2 wt\% (generally trace ICP analytes, $A A$ arialytes, and radionuclides) are considered negligible in this assessment. The assays that will contribute analytes to the mass balance will be the ICP fusion, IC, total carbon, total cyanide assays, and the gravimetric wt\% water measurement. The ICP fusion value does not include nickel, which is a significant analyte in the sample but may be biased high. However, for the purpose of this exercise, the nickel value from the respective acid leach preparations will be inserted into the total mass of ICP fusion analytes to account for it.

Without considering the physical and chemical properties of the waste matrix and the context of the process history, the mass balances produced from these assays account for 77.2 to 97.9 percent of the mass. However, this range of recovery is expected because it is known that there are analytes present that were not measured in the analysis of the samples. The IC anions only measure the water-soluble components; there is a substantial insoluble residue that must contain additional anions. There is no measurement of the sulfide content in any of the assays, even though it has been previously established that $28,100 \mathrm{~g}-\mathrm{mol}$ of $\mathrm{S}^{-2}$, was used in scavenging ${ }^{60} \mathrm{Co}$. Thus, an additional contribution of $2100 \mu \mathrm{g} / \mathrm{g}$ has been estimated as necessary to aid in closing the balance. Bismuth was not reported in the assays, and $\mathrm{BiPO}_{4}$ first cycle waste was recorded as being disposed here, introducing a potential shortfall.

Aluminum is likely present as $\mathrm{Al}(\mathrm{OH})_{3}$, and other transition metals are also likely present as hydroxides or hydrous metal oxides. Neither hydroxide. ion or oxide content has been measured in the waste, introducing additional sources of shortfall in the recovery. Therefore, multipliers for aluminum (2.9), iron (1.6), nickel (1.6), and uranium (1.3) will be used to account for the unmeasured hydroxide or oxygen, which are assumed to be present in combination with these analytes. Only metals making weight percent contributions to the waste matrix will be adjusted in this manner; the trace metals will be assumed to be lost in the error of the major constituents. Adjustments will be made individually for TOC, TIC, and total cyanide. It is assumed that the TOC and TIC assays did not consume or measure any cyanide present. In addition, a significant disparity can be accounted for by comparing the soluble phosphorus from the water leach ICP (and assuming that it is $\left.\mathrm{PO}_{4}^{3-}\right), \mathrm{PO}_{4}^{3-}$ values from the IC, and the phosphorus from the ICP fusion assay; the phosphate is only 27 to 44 percent soluble. The water leach ICP and IC values agree within 3 percent, strongly suggesting that the soluble phosphorus in the waste matrix is present as $\mathrm{PO}_{4}^{3-}$. The process history of the tank also indicates that large amounts of phosphate were used to encourage precipitate formation. Therefore, an assumption that the phosphorus in the 
fusion assay represents an insoluble $\mathrm{PO}_{4}^{3-}$ is not unwarranted (convert the phosphorus in the ICP assay to $\mathrm{PO}_{4}^{3-}$ and add it along with the water soluble phosphate and other anions). A minor accounting shift is now necessary to avoid double counting (subtract the ICP fusion phosphorous value).

Accounting for the analytes in this manner aids in closing agreement and improving the percent recoveries to between 96.6 percent and 119.3 percent (near quantitative recoveries). However, there remain some aspects of the waste matrices that require examination. Tables 5-34, 5-35, and 5-36 present mass balances that have been adjusted to compensate for the contributions of unmeasured (but likely) analytes combined with the measured analytes. There may have been some error introduced from drying of the sample during the preparation of the core composite, especially in the case of core 34, where the subsegments have a substantialiy higher water content than does the core composite, biasing the results low. In the case of Core 35 , the disparity between the gravimetric water measurement and the TGA water content also suggests (1) drying of the sample before the gravimetric assay; or (2) incomplete drying during the gravimetric test, which biases the results low.

Table 5-34. Adjusted Mass Balance: Core 34 Composite.

\begin{tabular}{|l|c|}
\hline \multicolumn{1}{|c|}{ Assay } & $\begin{array}{c}\text { Concentration } \\
(\mu \mathrm{g} / \mathrm{g})\end{array}$ \\
\hline $\begin{array}{l}\text { ICP--Fusion (+ Ni from acid leach; -P; } \\
\mathrm{Al}, \mathrm{Fe}, \mathrm{Ni}, \mathrm{U}, \text { adjustments) }\end{array}$ & 329,000 \\
\hline $\begin{array}{l}\mathrm{IC} \mathrm{Anions}_{\mathrm{O}}\left(\mathrm{TOC} \mathrm{TIC} \text {, and } \mathrm{CN}^{-} \text {adjustments; }\right. \\
\left.+\mathrm{P} \mathrm{PO}_{4} ;+\mathrm{S}^{2-}\right)\end{array}$ & 306,000 \\
\hline Gravimetric Water & 380,000 \\
\hline Total $(1,000,000 \mu \mathrm{g} / \mathrm{g})$ & $1,015,000$ \\
\hline
\end{tabular}

Table 5-35. Adjusted Mass Balance: Core 35 Composite.

\begin{tabular}{|c|c|}
\hline Assay & $\begin{array}{c}\text { Concentration } \\
(\mu \mathrm{g} / \mathrm{g})\end{array}$ \\
\hline $\begin{array}{l}\text { ICP--Fusion (+ } \mathrm{Ni} \text { from acid leach; }-\mathrm{P} \text {; } \\
\mathrm{Al}, \mathrm{Fe}, \mathrm{Ni}, \mathrm{U} \text {, adjustments) }\end{array}$ & 414,000 \\
\hline $\begin{array}{l}\text { IC Anions }\left(\mathrm{TOC} \text { TIC, and } \mathrm{CN}^{-} \text {adjustments; }\right. \\
\left.+\mathrm{P} \text { as } \mathrm{PO}_{4}^{3-} ;+\mathrm{S}^{2-}\right)\end{array}$ & 212,000 \\
\hline Gravimetric Water & 340,000 \\
\hline Total $(1,000,000 \mu \mathrm{g} / \mathrm{g})$ & 966,000 \\
\hline
\end{tabular}


Table 5-36. Adjusted Mass Balance: Core 36 Composite.

\begin{tabular}{|c|c|}
\hline Assay & $\begin{array}{c}\text { Concentration } \\
(\mu \mathrm{g} / \mathrm{g})\end{array}$ \\
\hline $\begin{array}{l}\text { ICP--Fusion (+ Ni from acid leach; }-\mathrm{P} ; \\
\mathrm{Al}, \mathrm{Fe}, \mathrm{Ni}, \mathrm{U}, \text { adjustments) }\end{array}$ & 404,000 \\
\hline $\begin{array}{l}\text { IC Anions (TOC, TIC, } \mathrm{CN}^{-} \text {adjustments; +P } \\
\left.\text { as } \mathrm{PO}_{4}^{3-} ;+\mathrm{S}^{2-}\right)\end{array}$ & 339,000 \\
\hline Gravimetric Water & 450,000 \\
\hline Total $(1,000,000 \mu \mathrm{g} / \mathrm{g})$ & $1,193,000$ \\
\hline
\end{tabular}

\subsubsection{Suggested Components of Waste Matrix}

The actual composition of the waste matrix is quite complex, and trace amounts of various compounds probably exist in the tank. However, with some simple assumptions regarding how the anions and cations will combine, a list of the most probable compounds that exist in the waste matrix and contribute significantly to its overall makeup can be developed.

Table 5-37 is a condensed version of a more general chart found on page D-147 in the Handbook of Chemistry and Physics 64 $\frac{\text { th }}{E d}$. (Weast 1984). It provides solubility data on some of the most common anions and cations.

Table 5-37. Probable Solids in the Waste Matrix.

\begin{tabular}{|l|c|c|c|c|c|c|c|c|}
\hline & $\mathrm{NO}_{2}^{-}$ & $\mathrm{NO}_{3}^{-}$ & $\mathrm{PO}_{4}^{3-}$ & $\mathrm{SO}_{4}^{2-}$ & $\mathrm{OH}^{-}$ & $\begin{array}{c}\mathrm{CN}^{-} \\
\text {(as } \mathrm{Fe}(\mathrm{CN})_{6}^{-}\end{array}$ & $\mathrm{CO}_{3}^{2-}$ & $\mathrm{S}^{2-}$ \\
\hline $\mathrm{Al}^{+3}$ & & & $\mathrm{PPT}$ & & $\mathrm{PPT}$ & $\mathrm{PPT}$ & & $\mathrm{NL}$ \\
\hline $\mathrm{Ca}^{+2}$ & & & $\mathrm{PPT}$ & $\mathrm{PPT}$ & & & $\mathrm{PPT}$ & \\
\hline $\mathrm{Fe}^{+2,+3}$ & & & & & $\mathrm{PPT}$ & $\mathrm{PPT}$ & $\mathrm{PPT}$ & $\mathrm{PPT}$ \\
\hline $\mathrm{Na}^{+}$ & & & & & & & & \\
\hline $\mathrm{Ni}^{+2}$ & & & $\mathrm{PPT}$ & & $\mathrm{PPT}$ & $\mathrm{PPT}$ & $\mathrm{PPT}$ & $\mathrm{PPT}$ \\
\hline $\mathrm{U}^{+6}$ & & $\mathrm{NL}$ & $\mathrm{PPT}$ & $\mathrm{PPT}$ & $\mathrm{PP}$ & & & $\mathrm{PPT}$ \\
\hline
\end{tabular}

PPT = Precipitate forms .

$N L=$ Precipitate formation not likely under tank conditions.

From the earlier tables and process information, chloride, fluoride, sulfide, and even ferrocyanide will not be significant mass contributors to the waste matrix. Sulfide and cyanide precipitates are significant because they provide a potential fuel source; however, it is generally believed that the sulfides were eventually converted to sulfates. Sodium, $\mathrm{NO}_{2}^{-}$, and $\mathrm{NO}_{3}^{-}$are highly soluble, and thus probably do not contribute much to the insoluble solids. However, they contribute significantly to the overall solids content of the waste (dissolved + insoluble solids). In addition, they represent 
three of the four most prevalent analytes, after water, in the waste. No analytical measurement of hydroxide was made, but it is known that in the process history of tank 241-C-112, basic solutions were added routinely to the tank. Likely candidates for the insoluble solids are as follows:

- Aluminum hydroxide, $\mathrm{Al}(\mathrm{OH})_{3}$

- Aluminum phosphate, AlPO,

- Tetraaluminum ferrocyanide, $\mathrm{Al}_{4}\left[\mathrm{Fe}(\mathrm{CN})_{6}\right]_{3}$

- Calcium phosphate, $\mathrm{Ca}_{3}\left(\mathrm{PO}_{4}\right)_{2}$

- Calcium sulfate, $\mathrm{CaSO}_{4}$

- Calcium carbonate, $\mathrm{CaCO}_{3}$

- Iron carbonate, $\mathrm{FeCO}_{3}$

- Iron(II) hydroxide, $\mathrm{Fe}(\mathrm{OH})_{2}$

- Iron(III) hydroxide, $\mathrm{Fe}(\mathrm{OH})_{3}$

- Iron(II) phosphate, $\mathrm{Fe}_{3}\left(\mathrm{PO}_{4}\right)_{2}$

- Iron(III) phosphate, $\mathrm{FePO}_{4}$

- Iron sulfide, FeS

- Iron(III) ferrocyanide, $\mathrm{Fe}_{4}\left[\mathrm{Fe}(\mathrm{CN})_{6}\right]_{3}$

- Disodium nickel ferrocyanide, $\mathrm{Na}_{2} \mathrm{NiFe}(\mathrm{CN})_{6}$

- Nickel carbonate, $\mathrm{NiCO}_{3}$

- Nickel sulfide, Nis

- Nickel hydroxide, $\mathrm{Ni}(\mathrm{OH})$

- Dinickel ferrocyanide, $\mathrm{Ni}_{2} \mathrm{Fe}(\mathrm{CN})_{6}$

- Uranyl phosphate, $\mathrm{UO}_{2} \mathrm{HPO}_{4} \cdot 4 \mathrm{H}_{2} \mathrm{O}$

- Uranyl hydroxide, $\mathrm{UO}_{2}(\mathrm{OH})_{2}$

- Uranyl sulfide, UO,S

- Uranyl sulfate, $2\left(\mathrm{UO}_{2} \mathrm{SO}_{4}\right) \cdot 7 \mathrm{H}_{2} \mathrm{O}$.

${ }_{90}^{\text {The }}{ }^{137} \mathrm{Cs}$ present is still apparently bound with the ferrocyanide, and the ${ }^{90} \mathrm{Sr}$ is probably bound with phosphate, carbonate, or sulfate.

\subsubsection{Comparison to Theoretical Estimates and Simulant Studies}

Agreement between synthetic sludge properties and observed waste material characteristics is within the constraints of the synthetic recipes and assumptions regarding chemical behavior in tank 241-C-112. Comparisons with Core 35 were not made because of its small sample size. On this basis it was assumed that valid comparisons could not be made, and that core 35 was not a representative sample of the tank waste. Table 5-38 compares some properties and analyte concentrations of the waste materials and comparable simulants. 
Table 5-38. Tank 241-C-112 Comparison of Waste Material with Simulants for Selected Analytes.

\begin{tabular}{|c|c|c|c|}
\hline Analyte & $\begin{array}{l}\text { In Farm } \\
\text { simulant } \\
\text { values }\end{array}$ & $\begin{array}{l}\text { Core } 34 \text { values } \\
\text { subsegment range } \\
\text { (composite value) }\end{array}$ & $\begin{array}{l}\text { Core } 36 \text { values } \\
\text { subsegment range } \\
\text { (composite value) }\end{array}$ \\
\hline $\mathrm{Ni} u g / g^{*}$ & 18,700 & $\begin{array}{c}22,200 \text { to } 28,300 \\
(30,000)\end{array}$ & $\begin{array}{c}900 \text { to } 23,000 \\
(12,800)\end{array}$ \\
\hline $\begin{array}{l}\text { Wt\% } \mathrm{H}_{2} \mathrm{O} \\
\text { Gravimetric }\end{array}$ & $51 \%$ & $\begin{array}{c}45 \text { to } 58 \% \\
(38 \%)\end{array}$ & $\begin{array}{c}41 \text { to } 64 \% \\
(45 \%)\end{array}$ \\
\hline $\begin{array}{l}\text { Wt\% } \\
\text { Total cyanide } \\
\text { dry basis }\end{array}$ & $\begin{array}{l}9.1 \text { to } \\
11.3 \%\end{array}$ & $\begin{array}{c}0.43 \text { to } 0.83 \\
(0.97)\end{array}$ & $\begin{array}{c}0.40 \text { to } 0.92 \\
(0.71)\end{array}$ \\
\hline $\begin{array}{l}\Delta H \\
k J / d r y g\end{array}$ & -1.2 & $\begin{array}{c}-0.01 \text { to }-0.03 \\
(-0.02)\end{array}$ & $\begin{array}{c}-0.01 \text { to }-0.03 \\
(-0.04)\end{array}$ \\
\hline Density $\mathrm{g} / \mathrm{ml}$ & 1.39 & Bulk Value: 1.5 to 1.6 & Bulk Value: 1.3 to 1.6 \\
\hline
\end{tabular}

* $\mathrm{Ni}$ analysis is potentially biased high. Values are derived from ICP fusion performed in a $\mathrm{Ni}$ crucible. However, in each case the blank value was an order of magnitude (or greater) less than the measurement. The fusion values are comparable with acid digestion values, where both are available. 


\subsection{INTERPRETATION OF ANALYTICAL RESULTS}

\subsection{TANK 241-C-112 WASTE PROFILE}

Tank 241-C-112 received four major types of waste likely to deposit solids during its operating history. The waste types, in order, were as
follows:

- Bismuth phosphate first cycle decontamination waste (IC)

- Unscavenged uranium recovery waste (UR)

- Ferrocyanide-scavenged waste (FeCN) from scavenging of UR waste initially stored in other tanks

- Cladding wastes (CW).

A small volume of strontium semiworks waste subsequently was received by the tank and a relatively large volume of B Plant ion-exchange waste after that. These last wastes would not be expected to contribute large amounts of solids to the tank. The purpose of this section is to attempt to identify the location of the tank waste solids, thereby allowing estimation of the tank inventory for various analytes of importance.

The approach taken to identify the waste profile was to examine the subsegment assays for analytes distinct to the waste types that were disposed in the tank, and combine that information with what is known regarding the tank's process history. The first waste placed in the tank, via the cascade inlet from tank 241-C-111, was $\mathrm{BiPO}_{4}$ IC waste. This waste would be comparatively high in bismuth, phosphate, and aluminum because aluminum decladding waste was combined with it. The IC solids volume was measured as $57,000 \mathrm{~L}(15,000 \mathrm{gal})$ in 1952 (Anderson 1990). This volume would amount to $32.8 \mathrm{~cm}$ (12.9 in.) in the tank bottom. The tank next received UR waste with solids comparatively high in uranium and iron and low in bismuth and aluminum. The available records do not show whether this waste was added directly to the tank or via the cascade overflow line from tank 241-C-111. Assuming direct addition to tank 241-C-112, the estimated volume of these solids would be approximately $55,000 \mathrm{~L}(14,500 \mathrm{gal})$ at 1.8 vol\% of the waste input. This corresponds to $13.5 \mathrm{~cm}(5.3 \mathrm{in}$.) distributed evenly across the tank.

The tank then received ferrocyanicie-scavenged waste. The solids from this waste would be high in nickel, calcium, cyanide (as ferrocyanide), ${ }^{137} \mathrm{Cs}$, and uranium, although the uranium may have settled out in the tank originally receiving the UR waste. Because some of the ferrocyanide waste feed was concentrated IC waste (evaporator bottoms), the waste could also be high in aluminum. The estimated solids volume in tank 241-C-112 at the end of the scavenging program was between 174,000 and $318,000 \mathrm{~L}(46,000$ and $84,000 \mathrm{gal})$. This would amount to 61.5 to $96.5 \mathrm{~cm}(24.2$ to $39.0 \mathrm{in}$. distributed evenly across the tank. The last major waste type was aluminum cladding waste. These materials would be high in aluminum and silica; however, the solids volume is unknown because the majority of the solids would be deposited in the first tank to receive the wastes, which was not tank 241-c-112. The grey/white solids seen in the video recordings of the 
core extrusions are believed to be cladding waste; the tan/dark brown solids are thought to be ferrocyanide sludge. Their observed position during extrusion agrees with the historical record. The volume of strontium semiworks waste was small and probably would not have been visually detectable. However, it would have a relatively high ${ }^{90} \mathrm{Sr}$ content because it includes strontium recovery and purification waste losses. This characteristic would be readily observable in the radiochemistry analyses.

\subsection{REVIEW OF THE SUBSEGMENT ANALYTE PROFILES}

The following conclusions are drawn from review of the subsegment analyses presented in Section 5.0.

\section{Core 34}

Chemical analyses indicate this material is ferrocyanide waste. The relatively high nickel, calcium, TOC, and ${ }^{137} \mathrm{Cs}$ support this conclusion. In addition, the total cyanide analysis indicates residual cyanide in the waste. The DSC traces show a small exotherm in the same temperature range where the In Farm simulants begin to show reactions; however, the overall energy release is somewhat lower than expected for the measured cyanide concentration and much lower than that expected from simulant information. The high uranium value in subsegment $2 D$ is believed to be due to some UR waste a) so being present.

\section{Core 35}

The only solids recovered from this core were $7.6 \mathrm{~cm}(3.0 \mathrm{in.})$ of solids from the lower segment (assumed to be subsegment 2D); thus, the waste origin is indeterminate. Some analytes (e.g., nickel, aluminum, calcium, and phosphate), match Core 34 well. Other analytes such as nitrate, nitrite, uranium, and TOC/total carbon values agree better with Core 36 . No total cyanide measurements are available.

\section{Core 36}

Subsegments $1 C$ and 10 show high nickel, calcium, TOC, and ${ }^{137} \mathrm{Cs}$ analyte concentrations characteristic of ferrocyanide wastes. Subsegments $2 \mathrm{C}$ and $2 \mathrm{D}$ are relatively low in these analytes but high in uranium and phosphate, which is typical of UR wastes. The $2 A$ and $2 B$ subsegments appear to be a mix of these two types of waste. The total cyanide values trend generally lower as a function of waste depth. In subsegments $1 C, 10,2 A$, and $2 B$, the DSC traces show a small exotherm in the same temperature range where the simulants show reactions; again the exotherms were much lower than expected. Although some measurable cyanide is in the lower subsegments, no corresponding exotherm is recorded in the DSC measurements. High TOC and ${ }^{90} \mathrm{Sr}$ values in $36-1 \mathrm{C}$ may indicate hot semiworks/strontium semiworks, which would have had organic complexants. 


\subsubsection{Tank Entrance/Exit Effects on Analyte Distribution}

Figure 6-1 shows an elevation and plan of where the core samples were taken. Important items to note are that Core 36 (and 35) were taken from risers near the ferrocyanide waste inlet, while Core 34 was obtained near the waste pumpout riser. The decant "float and flex" pump contained a 6.1-m $(20-\mathrm{ft})$ section of flexible hose that could traverse a relatively wide area on that side of the tank. The cascade fill line (where $\mathrm{BiPO}_{4} 1 \mathrm{C}$ waste entered the tank) is closer to the Core 34 sample point than to the Core 35 and 36 risers. The elevation view shows this is a shallow-dish bottom tank and the bottom of the core samples were $33 \mathrm{~cm}$ (13.0 in.) above the centerline inside bottom of the tank. Also shown is the waste surface, measured from the centerline as $115.1 \pm 1.3 \mathrm{~cm}(45.3 \pm 0.5 \mathrm{in.})$. The total sample and solids recovery for each of the three cores is shown as well as the top and bottom of the sample segments. If the solids recovery in the bottom of segment core 34 , is adjusted to equal core 36 , there is a $18.3-\mathrm{cm}(7.2-$ in.) decrease in the top solids surface going from riser 8 across the tank to riser $2(18.3-\mathrm{cm}$ [7.2-in.] decrease in approximately $20.1 \mathrm{~m}$ [66 ft]). Figure $6-2$ shows a representation of the overall waste profile of tank $241-C-112$ and the assumed volumes, boundaries, and positions of the various individual layers as they are believed to exist.

As new wastes entered the tank and distributed themselves across the tank, the material under and around the tani pumpout (Core 34) would be routinely disturbed (and occasionally solids transferred) in behavior akin to the last in-first out principle. However, the material beneath the waste inlet (Cores 35 and 36 ) would be disturbed initially but, over time, large stratified layers resistant to mixing would eventually build up. Thus the influence of the waste inlet and outlet locations provides insight to the contrast in the analyte and waste profiles between Cores 34 and 36 .

The ${ }^{137} \mathrm{Cs}$ concentrations are nearly uniform in the core composites. However, the ${ }^{137} \mathrm{Cs}$ concentration as a function of depth shows profiles consistent with the wastes believed to be associated with the subsegments--low ${ }^{137} \mathrm{Cs}$ values for unscavenged UR wastes, higher ${ }^{137} \mathrm{Cs}$ values for ferrocyanide wastes. In addition, the ${ }^{137} \mathrm{Cs}$ profile was relatively uniform in Core 34 ; it shows a decreasing trend as a function of depth in core 36 . The ${ }^{90} \mathrm{Sr}$ concentration, however, shows a highly skewed distribution between cores 34 and 36 and unusual concentration profiles as a function of depth for both cores. Core 34 has extremely high ${ }^{90} \mathrm{Sr}$ concentration throughout; Core 36 is high in the top subsegment and then the concentration falls dramatically. The consistently high ${ }^{90} \mathrm{Sr}$ values in Core 34 are believed to be a localized phenomenon and not representative of the ${ }^{90} \mathrm{Sr}$ concentration in the tank. This observation is supported by heat-load estimates developed from thermal models of the temperature profiles in the tank. In addition, no mechanism has been demonstrated that has the capability to concentrate radionuclides to levels of concern (Dickinson et al. 1993). The temperature profile model results give a heat load of $2.37 \pm 0.06 \mathrm{~kW}$ (Appendix C). A preliminary heat- load estimate developed from the Core 34 cesium and strontium inventories representing the bulk analyte concentrations is $5.63 \mathrm{~kW}$. This value is not realistic, given the temperature measurements of the tank waste. Another preliminary estimate, calculated from Core 36 values $(2.33 \mathrm{~kW})$, is much more in agreement with the 
Figure 6-1. Elevation and Plan of Tank 241-C-112.
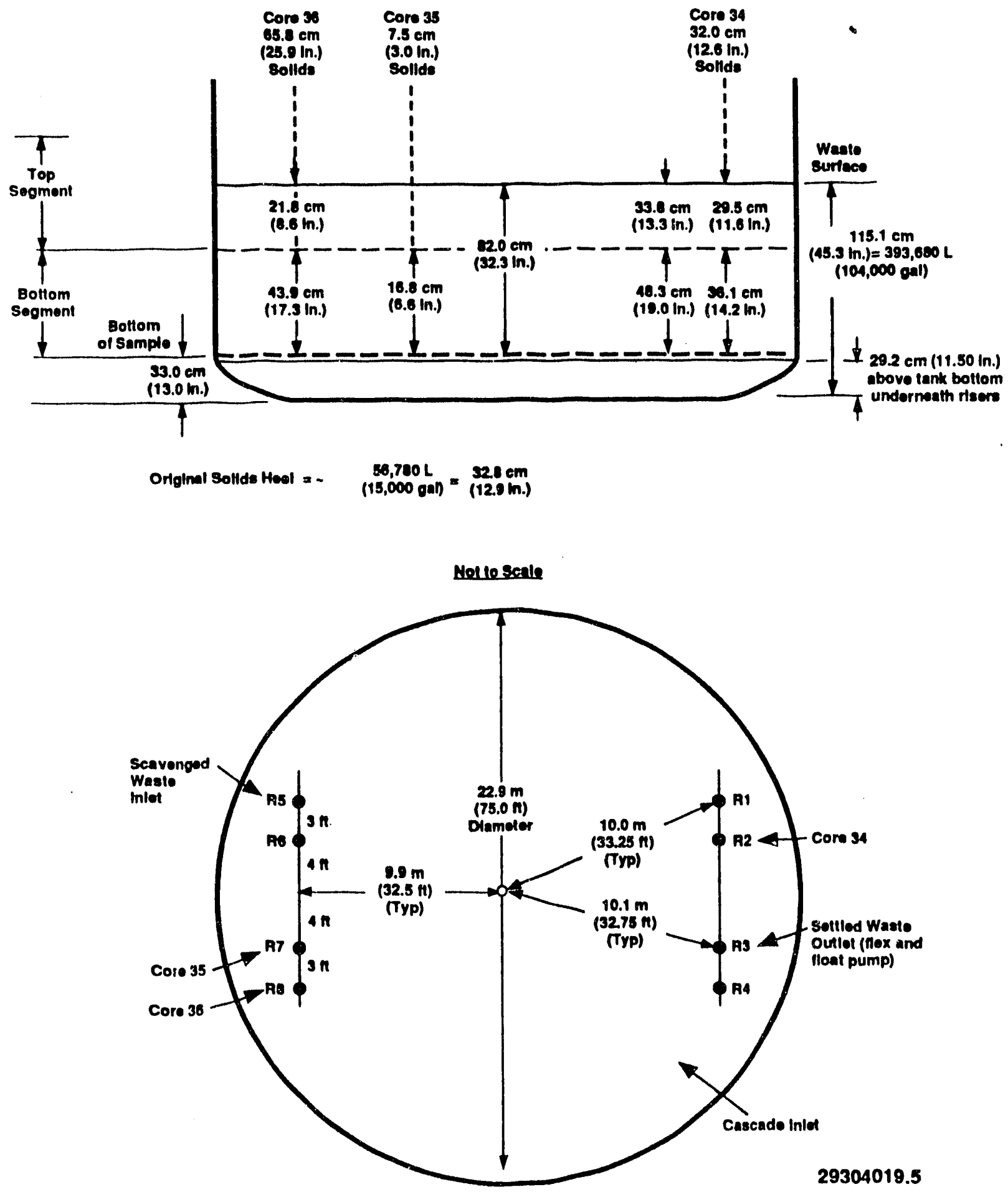
Figure 6-2. Waste Profile of Tank 241-C-112.

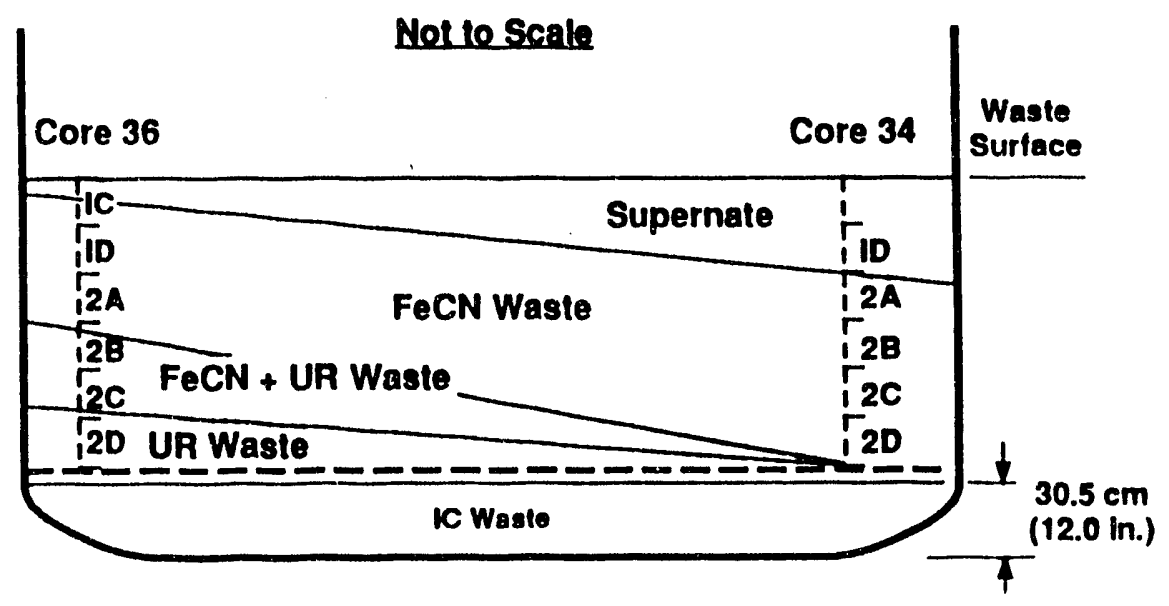

29304019.7

- Dished Bottom: First cycle $\mathrm{BiPO}_{4}$ waste or unscavenged uranium recovery (UR) waste $57,700 \mathrm{~L}(15,000 \mathrm{gal})$

- Tank Layer 1: Unscavenged UR waste 37,100 L (9,800 gal)

- Tank Layer 2: Unscavenged UR waste and ferrocyanide scavenging waste 37,100 L $(9,800$ gal $)$

- Tank Layer 3: Ferrocyanide scavenging waste 158,000 L (41,800 gal)

- Supernatant: $137,000 \mathrm{~L}(36,300 \mathrm{gal})$. 
heat-load model value for tank 241-C-112. Core 35 does not have enough waste to provide a basis for a meaningful comparison. Using the model heat load as a basis, a realistic ${ }^{90} \mathrm{Sr}$ concentration/inventory may be developed. This will be shown in Section 6.3. The high localized ${ }^{90} \mathrm{Sr}$ values may be attributable to the location of the core samples relative to the waste inlet and outlet.

One of the upper subsegments of Core 36 (36-1C) was relatively high in aluminum, which is typical for cladding wastes that were deposited on top of the ferrocyanide wastes. Aluminum shows similar distribution behavior to ${ }^{90} \mathrm{Sr}$; a high and relatively uniform concentration in core 34 , and in Core 36 , a much lower concentration that decreases as a function of depth. This may be reasonable because the same tank conditions and disturbances would have affected later waste transfers. As noted previously (Borsheim and Simpson 1991), some large transfers from tank 241-C-112 in the 1970's probably transferred some of the uppermost solids from the tank. None of the core sample subsegments demonstrated convincing evidence of being $1 C$ waste solids. Unfortunately, the bismuth values that d:stinguish this waste were not determined via the ICP fusion analysis. It is expected that the bulk of the $\mathrm{BiPO}_{4} \mathrm{lC}$ waste lies below the depth that can be core sampled through the available risers.

\subsubsection{Comparisons with the Borsheim/ Simpson Model Estimates}

Calculations of the ${ }^{137} \mathrm{Cs}$, nickel, and $\mathrm{Fe}(\mathrm{CN})_{6}^{4-}$ inventories are analytes appropriate for comparison with the model. Assumptions regarding the tank used in the calculations for the analytical estimates, and the calculations themselves, are presented in Appendix A. Table 6-1 presents comparisons of the calculated values with the original and revised Borsheim/Simpson values after scavenging was finished.

Table 6-1. Comparisons of Initial and Revised Borsheim/Simpson Model Estimates with Values Calculated from Analytical Results

\begin{tabular}{|c|c|c|c|c|c|}
\hline \multirow[t]{2}{*}{ Analyte } & \multicolumn{2}{|c|}{ Borsheim/Simpson } & \multicolumn{2}{|c|}{ Revised Borsheim/Simpson } & $\begin{array}{l}\text { Analytical } \\
\text { Estimates }\end{array}$ \\
\hline & Retained & Input & $\begin{array}{c}1.0 \\
\text { (retained) vol\% }\end{array}$ & $\begin{array}{c}1.5 \\
\text { (retained) vol\% } \\
\end{array}$ & $\begin{array}{c}\text { (from } \\
\text { Secition 6.3) }\end{array}$ \\
\hline $\mathrm{Ni}$, moles & 31,000 & 78,500 & $98,800^{1}$ & $93,300^{1}$ & 95,200 \\
\hline $\begin{array}{l}{ }^{137} \mathrm{Cs}, \mathrm{KCi} \\
\text { (decayed to 1993) }\end{array}$ & 124.8 & 334.8 & 224.7 & 205.9 & 217.2 \\
\hline $\begin{array}{l}\mathrm{Fe}(\mathrm{CN})_{6}^{-4}, \\
\text { moles }\end{array}$ & 31,000 & 78,500 & 65,900 & 60,400 & 8,700 \\
\hline
\end{tabular}


Several assumptions must be made to calculate the tank contents before making comparisons to the Borsheim/Simpson model predictions for selected analytes. In addition, several assumptions of that model must be examined because they affect the original predictions regarding the waste in the tanks, such as (1) the assumption of 4.25 vol\% solids formation (representative of the U Plant materials, not the In Farm waste); (2) no additional settling or compaction; (3) negligible waste transfer (input/output) effects; and (4) transfers after the scavenging program did not meaningfully affect the condition of the waste. However, at the time they were obtained, these data and assumptions were the best available. As the ferrocyanide program evolved, more and better data became available.

The development of the model provided some preliminary understariding to the condition and distribution of the waste in the tank. Generally, the model gave values that were within $\pm 50 \%$ of the values calculated from the analytical results. Where agreement was not good, further investigation found reasonable sources for the difference. The range of values developed from the model was adequate for defining initial conditions (and bounding values); however, for analytes $1 \mathrm{ike}{ }^{90} \mathrm{Sr}$ and ferrocyanide itself, further process history contributed meaningfully to the present inventory in the tank as determined from laboratory analysis. Further clarification was provided by physical and chemical characterization of flowsheet materials, as well as aging and energetics studies. The model functioned well within the constraints placed on its operation, and it remains flexible enough to run further trials with new parameters, which have been done and are presented in Appendix $A$.

As noted previously, the analytical nickel values are biased high, perhaps as much as 20 to 25 percent, by the use of a nickel crucible in the ICP fusion assay. Because the nickel tracer is biased high and it is unknown how much of the ferrocyanide solids were actually transported to the cribs, initial agreement is not good between the model estimates and the analytica? results. In addition, ${ }^{60}$ Co scavenging was done in several of the batches that were settled in tank 241-C-112, adding to the nickel inventory but not contributing to the ferrocyanide content. Approximately $32,900 \mathrm{~g}$-mol of additional nickel was added to the tank in these process runs. Therefore, the nickel inventory determined from Borsheim/Simpson should be adjusted upwards by that amount to account for the additional nickel; the model only accounted for nickel deposited with ferrocyan Je. Agreement between the model values and the analysis-based estimates closes when the analytical bias is considered and with inventory adjustments from the cobalt-scavenging contribution.

However, with all of the caveats associated with it, the nickel assay provides no more than a bounding condition for the ferrocyanide inventor!. as well as indicating that ferrocyanide was (or is) present.

Values for ${ }^{137} \mathrm{Cs}$ from Borsheim/Simpson adequately bound the inventories calculated from the analytical results. The calculated inventory can vary somewhat depending on the which core's density and roncentration values are used in the computation. No overt biases were found in the analysis, and no other waste type that was disposed to tank $241-\mathrm{C}-112$ is believed to have a
${ }^{137} \mathrm{Cs}$ concentration high enough to confound inventory estimates (unlike ${ }^{90} \mathrm{Sr}$ ). In addition, ${ }^{137} \mathrm{Cs}$ values provide a potential check on the waste retention of the tank. Cesium was widely dispersed in the slurry while it was settling. 
and its concentration profile as a function of depth is relatively uniform in the subsegments believed to be ferrocyanide waste. The Borsheim/Simpson model has a significant amount of solids disposed to the cribs as a result of some of the model assumptions. If the ${ }^{137} \mathrm{Cs}$ values are used to estimate the waste retention in the tank, the amount of ferrocyanide waste retained in the tank is much higher than the estimated 40 percent retention from present model values.

A large degree of uncertainty is associated with the amount of ferrocyanide waste that may have been disposed to the cribs. The original model run has a large amount of solids being discharged, even though the available records indicate that the discharged effluent had only traces of suspended solids in it. The model basis of 4.25 vol\% has been determined to be flawed for this waste type. Simulant studies indicate that an appropriate solids formation value for the In Farm process is 1.0 to 1.5 vol\% (Jeppson and Wong 1993). This additional information can be used to develop better model parameters and waste inventory estimates. A rerun of the model using these new volume parameters gives significantly better agreement.

The ferrocyanide inventory calculated from the total cyanide analysis remains $8,700 \mathrm{~g}-\mathrm{mol}$. The revised model value for the estimated remaining ferrocyanide of 60,000 to $66,000 \mathrm{~g}$-mol is significantly higher than that determined from experimental results. The model estimated the total

ferrocyanide used in processing waste through tank $241-\mathrm{C}-112$ is $78,500 \mathrm{~g}-\mathrm{mol}$. Given the improvement in agreement of the other analytes, this result, along with the energetic results, suggests a degradation or aging mechanism of some type.

\subsection{CALCULATED BULK INVENTORIES OF SELECTED ANALYTES}

Several safety issues are defined by certain bulk amounts or weight percent of a given analyte. Tables 6-2 through 6-5 present the calculated bulk amounts of some selected analytes and their weight percent contribution to the waste matrix. The gross waste inventory in the tank is estimated to be $608,000 \mathrm{~kg}(434,000 \mathrm{~kg}$ wet solid, and $174,000 \mathrm{~kg}$ of drainable liquid). Appendix $A$ presents the data, assumptions, and calculations used to determine the following values.

Table 6-2. Energetics Related Analyte Values.

\begin{tabular}{|l|c|c|c|c|c|}
\hline & TOC & Total Cyanide & $\mathrm{NO}_{2}^{-}$ & $\mathrm{NO}_{3}^{-}$ & $\mathrm{H}_{2} \mathrm{O}$ \\
\hline Bulk Inventory (Mg) & 1.86 & 1.55 & 27.78 & 37.32 & $355.37^{1}$ \\
\hline Wt\% (total) & 0.31 & 0.25 & 4.57 & 6.14 & $58.42^{1}$ \\
\hline $\begin{array}{l}\text { Bulk Inventory, } \\
\text { wet solids (Mg) }\end{array}$ & 1.56 & 1.35 & 18.19 & 24.76 & 233.22 \\
\hline Wt\% (wet solids) & 0.36 & 0.31 & 4.19 & 5.71 & 53.77 \\
\hline
\end{tabular}

1 Water content combines interstitial and free water (i.e., supernate).

TOC = Total organic carbon. 
The bulk inventory of disodium nickel ferrocyanide in the tank is $8,700 \mathrm{~g}$-mol, assuming the calculated inventory of total cyanide is present as that analyte. Molar ratios for ferrocyanide, nitrate, and nitrite (assuming this value for ferrocyanide) are $1: 10.1: 10.1$.

Table 6-3. Fission Product Inventory.

\begin{tabular}{|l|c|c|}
\hline & ${ }^{137} \mathrm{Cs}$ & ${ }^{90} \mathrm{Sr}$ \\
\hline $\begin{array}{l}\text { Bulk Inventory (Ci) } \\
\text { (wet solids) }\end{array}$ & 217,200 & 183,500 \\
\hline Heat Generation (w) & 1025 & 1230 \\
\hline
\end{tabular}

The total heat load of the tank is 2,255. The volumetric heat generation for the waste in the tank based on the solids volume is $7.8 \mathrm{E}-3 \mathrm{w} / \mathrm{L}$ solids at $1.50 \mathrm{~g} / \mathrm{mL}$.

Table 6-4. Plutonium/Americium Inventory.

\begin{tabular}{|l|c|c|c|}
\hline & ${ }^{238} \mathrm{Pu}$ & ${ }^{239 / 240} \mathrm{Pu}$ & ${ }^{241} \mathrm{Am}$ \\
\hline $\begin{array}{l}\text { Bulk Inventory (Ci) } \\
\text { (wet solids) }\end{array}$ & 5.9 & 67.3 & 330 \\
\hline Bulk Inventory (g) & 0.34 & 1,100 & 100 \\
\hline
\end{tabular}

Table 6-5. ICP Major Cation Inventory (Fusion Preparation).

\begin{tabular}{|l|l|l|l|l|l|r|r|}
\hline & $\mathrm{Al}$ & $\mathrm{Ca}$ & $\mathrm{Fe}$ & \multicolumn{1}{c|}{$\mathrm{Na}$} & $\mathrm{Ni}$ & \multicolumn{1}{c|}{$\mathrm{P}$} & \multicolumn{1}{c|}{$U$} \\
\hline Bulk Inventory $(\mathrm{Mg})$ & 4.34 & 6.08 & 8.38 & 40.12 & 5.52 & 10.08 & 22.09 \\
\hline Wt\% (Wet solids) & 1.00 & 1.40 & 1.93 & 9.25 & 1.27 & 2.32 & 5.09 \\
\hline
\end{tabular}

\subsection{GAMMA SCANNING OF CORE SAMPLE SEGMENTS}

Qualitative measurements of the gamma emitters in the waste were obtained. The information, al though interesting and somewhat useful, was not as comprehensive as was hoped and could have been obtained at less cost through a lower technology method or simply by waiting for extrusion and analysis of the sample. The scans showed that radiocesium is the only significant gamma emitter in the waste. After evaluation of the data results from the gamma scans from tank 241-C-112, a decision was made to suspend any further gamma scanning on the remaining ferrocyanide tanks until hard salt cake samples (e.g. tank 241-BY-104) can be obtained. This decision was made on several bases; however the most significant factor was cost. 
The information from the scan was also found to be an accurate indicator of core condition (i.e., full, partial, or empty) and it did confirm that there was some gross layering of the wastes, in addition to differences in activity between batches. This information is of some value because it allows modifications to the analysis plan prior to extrusion, if necessary, avoiding hot cell delays. Thus, field radiography is under consideration as a procedure to indicate percent recovery. The information regarding layering and variations batch content is also somewhat valuable; however, now that the hypothesis has been tentatively confirmed, the analytical horizons in the characterization plan for core sample analysis are now believed narrow enough to find ferrocyanide and ${ }^{137} \mathrm{Cs}$ concentrations.

Based on the information obtained from these initial scans, the cost associated with this analytical technique was not thought to be good value and drained resources from the program. Investigation of tank 24l-BY-104 core samples (salt cake and sludge) is the next gamma scanning effort under consideration. Those core samples differ enough in composition and process history for the technique to be of potential value.

In addition to the cost-benefit argument, PNL raised objections to continuing the gamma scanning effort because of the schedule delays caused by logistical problems in sample transport between the various facilities and hot cell scheduling. Given the limited sample transport, limited hot cell and personnel resources, and the uncertainty regarding the availability of these resources at any given time, the schedule constraints regarding data package delivery also became major considerations in discontinuing the effort. 


\subsection{QUANTITATIVE/STATISTICAL INTERPRETATION OF THE DATA}

This section contains the statistical analysis of core samples taken from tank 241-c-112. The analysis is divided into four sections. The first section contains mean concentration estimates in the form of confidence intervals for each analyte of interest. Second, an examination of samples taken at two locations from homogenized subsegments was conducted to determine the ability of the 325 Analytical Chemistry Laboratory to homogenize solid core segments. The results from this examination indicate that the 325 Analytical Chemistry Laboratory is able to homogenize core subsegments satisfactorily. The third section is a comparison of the core composite concentration estimates with a simulated core composite computed from individual subsegment data. In 89 percent of the cases tested, the core composite could not be statistically distinguished from the simulated core composite. This indicates that the ability of the 325 Analytical Chemistry Laboratory to make core composites is satisfactory. The last topic in this section addresses the issue of spatial (between core) variability and analytical error. Variance component estimates and confidence intervals are presented and discussed. In general, the spatial variability is of the same magnitude or larger than the analytical error.

Samples were obtained for subsegments $1 D, 2 B, 2 C$, and $2 D$ from Core 34 ; a single subsegment, $2 D$, from Core 35 ; and subsegments $1 C, 1 D, 2 A, 2 B, 2 C$, and 20 from Core 36. Drainable liquids were recovered from cores 34 and 35 . Composite samples were made from the homogenized subsegment samples for each core. It should be noted that the core 35 composite and subsegment 20 are one and the same. Drainable liquid composites were also made for cores 34 and 35. A sample and duplicate were taken from each core composite and prepared for analysis in the laboratory. Laboratory analyses were conducted on additional homogenized subsegment samples for the homogenization tests.

The laboratory results from tank 241-C-112 samples are tabulated in Appendix B. Sample preparations, assays, and analytes chosen for statistical evaluation are as follows: ICP acid digestion, ICP potassium hydroxide fusion dissolution, and ICP water leach analyses were conducted on all core composite samples and duplicates for aluminum, calcium, iron, sodium, nickel, lead, uranium, and phosphorous. Core 34 composite duplicate analys is results were not reported for ICP potassium hydroxide fusion dissolution and ICP water leach methods. The potassium hydroxidelnickel fusion dissolution was the only ICP method used to analyze subsegment results. Radiochemistry composite sample results were reported for uranium ${ }^{238} \mathrm{Pu},{ }^{239 / 240} \mathrm{Pu},{ }^{137} \mathrm{Cs}$, and ${ }^{90} \mathrm{Sr}$, as well as subsegment results for ${ }^{137} \mathrm{Cs}$ and ${ }^{30} \mathrm{Sr}$. Ion Chromatography analysis results for chloride, nitrite, nitrate, phosphate, and sulfate were reported for core composite and subsegment samples. The ICP acid digestion analysis results were used to evaluate the homogenization test samples. Figures for the homogenization test data are also found in Appendix B. Drainable liquids were recovered from Cores 34 and 35 . They are included in part of the analysis and results for concentration estimates. 


\subsection{CONCENTRATION ESTIMATES}

A task directed by WHC-EP-0210 to tank 241-C-112 was to estimate the constituent concentrations (Hill et al. 1991). This task was accomplished using means and appropriate confidence intervals (CI) on these means. It should be emphasized that concentration estimates will be obtained rather than an inventory of the tank.

Each segment was subdivided into subsegments. The subsegments were each homogenized (laboratory core homogenization ability is covered in

Section 4.0). Each core composite was formed by combining samples from the homogenized subsegments. The core composite sample was then also homogenized. Two al iquots were drawn from each core composite and prepared for chemical analysis. Concentration estimates were computed based on the results of these chemical analyses. Appendix B contains the core composite data used to obtain concentration estimates and intervals. The "NA" symbol indicates that the data is not available.

The concentration estimates are given in the form of 95 percent CIs on the mean concentration of each analyte in the tank. It is assumed that each sample and duplicate are analyzed independent of one another to yield adequate estimates of analytical error. Due to the hierarchical structure of the data, the analytical error alone is not the appropriate error term to use in the CI calculations. A linear combination of the analytical error and spatial variability is the appropriate measure of spread for the CIs. The derivation of the formulas used to calculate these CIs is given in a Westinghouse Hanford Company internal memo (Jensin and Whitcher 1993).

Tables 7-1,7-2,7-3,7-4, and 7-5 contain the following summary statistics for all three ICP analyses (acid digestion, water leach, potassium hydroxide/nickel fusion dissolution), radiochemistry, and IC anion analyses, respectively.

For some analytes the lower confidence limit $L$ was negative. Because concentrations are strictly greater than or equal to zero, any negative $L$ values were set to zero.

The drainable liquid composites (DLC) were added to the solid composite data to increase the information and, therefore, give more accurate $C I s$. Some of the DLC results from the ICP acid digestion analysis are quite different from the solid core composite results. For this reason two sets of summary statistics on all core composite results are presented, one including and another set excluding the DLC results. Plutonium, uranium, nickel, calcium, and iron DLC results are quite different than the solid core composite data. These differences will inflate the analytical error, which is a component in $\hat{\sigma}_{\bar{y}}^{2}$ for the CI. The DLCS do not create a problem for ICP acid digestion sodium analysis or any of the ICP water leach analyses.

A close examination of the ICP water leach sodium results revealed a large residual associated with one of the Core 36 composite result of $130,962 \mu \mathrm{g} / \mathrm{g}$. Its duplicate result was $85,753 \mu \mathrm{g} / \mathrm{g}$, which is with in the range of the other core composite results. Additional summary statistics are given excluding this outlying result. 
Table 7-1. Acid Digestion Inventory Statistics $(\mu \mathrm{g} / \mathrm{g})$.

\begin{tabular}{|c|c|c|c|c|c|c|}
\hline \multicolumn{7}{|c|}{ Excluding Drainable Liquid Composites } \\
\hline Analyte & $\bar{y}$ & BMS & $\hat{\sigma}_{\bar{y}}^{2}$ & $d f$ & $L$ & U \\
\hline Al & 24,464 & $7.65 E+08$ & $1.28 E+08$ & 2 & 0 & 73,056 \\
\hline $\mathrm{Ca}$ & 16,743 & $5.12 E+07$ & $8.53 \bar{i}+06$ & 2 & 4,179 & 29,307 \\
\hline $\mathrm{Fe}$ & 21,853 & $2.63 E+07$ & $4.40 E+06$ & 2 & 12,836 & 30,871 \\
\hline $\mathrm{Na}$ & 89,567 & $5.57 \mathrm{E}+08$ & $9.30 \mathrm{E}+07$ & 2 & 48,115 & 131,018 \\
\hline $\mathrm{Ni}$ & 13,113 & $3.20 \mathrm{E}+07$ & $5.33 E+06$ & 2 & 3,179 & 23,047 \\
\hline $\mathrm{Pb}$ & 2,553 & $4.59 E+06$ & $7.64 E+05$ & 2 & 0 & 6,315 \\
\hline u & 58,389 & $3.22 \mathrm{E}+09$ & $5.37 E+08$ & 2 & 0 & 158,129 \\
\hline$P$ & 22,915 & $9.4 E+07$ & $1.57 E+07$ & 2 & 5,864 & 39,967 \\
\hline \multicolumn{7}{|c|}{ Including Drainable Liquid Composites } \\
\hline Analyte & $\bar{y}$ & BMS & $\hat{\sigma}_{\bar{y}}^{2}$ & $d f$ & $\mathrm{~L}$ & U \\
\hline$A 1$ & 24,464 & $7.65 E+08$ & $1.28 E+08$ & 2 & 0 & 73,056 \\
\hline $\mathrm{Ca}$ & 10,189 & $8.35 \mathrm{E}+07$ & $8.34 E+06$ & 2 & 0 & 22,621 \\
\hline $\mathrm{Fe}$ & 13,473 & $5.28 E+07$ & $5.27 E+06$ & 2 & 3591 & 23,354 \\
\hline $\mathrm{Na}$ & 84,235 & $7.71 E+08$ & $7.71 E+07$ & 2 & 46447 & 122,024 \\
\hline $\mathrm{Ni}$ & 8,084 & $1.95 E+06$ & $1.95 E+06$ & 2 & 2078 & 14,089 \\
\hline $\mathrm{Pb}$ & 2,553 & $4.59 E+06$ & $7.64 \mathrm{E}+05$ & 2 & 0 & 6,315 \\
\hline U & 35,446 & $4.05 E+09$ & $4.05 E+08$ & 2 & 0 & 122,048 \\
\hline$P$ & 15,283 & $3.02 E+08$ & $3.02 E+07$ & 2 & 0 & 38,949 \\
\hline
\end{tabular}

$\bar{y}:$ arithmetic mean of the concentration data,

BMS: "between mean squares" from the one-way analysis of variance,

$\hat{\sigma}_{\bar{\gamma}}^{2}:$ estimated variance of $\bar{y}$,

df: degrees of freedom associated with BMS,

$L:$ lower limit to the $95 \%$ confidence inierval on the mean, and

$U$ : upper limit to the $95 \%$ confidence interval on the mean. 
Table 7-2. Potassium Hydroxide Fusion Dissolution Inventory Statistics $(\mu \mathrm{g} / \mathrm{g})$.

\begin{tabular}{|l|c|c|c|c|c|c|}
\hline Analyte & $\bar{y}$ & BMS & $\hat{\sigma}_{\bar{y}}^{2}$ & $\mathrm{df}$ & $\mathrm{L}$ & $U$ \\
\hline $\mathrm{Al}$ & 26,540 & $7.53 \mathrm{E}+08$ & $1.51 \mathrm{E}+08$ & 2 & 0 & 79,337 \\
\hline $\mathrm{Ca}$ & 19,950 & $6.56 \mathrm{E}+07$ & $1.31 \mathrm{E}+07$ & 2 & 4,367 & 35,533 \\
\hline $\mathrm{Fe}$ & 27,915 & $3.62 \mathrm{E}+07$ & $7.23 \mathrm{E}+06$ & 2 & 16,344 & 39,486 \\
\hline $\mathrm{Na}$ & 103,893 & $8.43 \mathrm{E}+08$ & $1.69 \mathrm{E}+08$ & 2 & 48,026 & 159,760 \\
\hline $\mathrm{Ni}$ & $\mathrm{NA}$ & $\mathrm{NA}$ & $\mathrm{NA}$ & $\mathrm{NA}$ & $\mathrm{NA}$ & $\mathrm{NA}$ \\
\hline $\mathrm{Pb}$ & 2,937 & $6.51 \mathrm{E}+0$ & $1.30 \mathrm{E}+06$ & 2 & 0 & 7,846 \\
\hline $\mathrm{U}$ & 80,730 & $2.87 \mathrm{E}+09$ & $5.74 \mathrm{E}+08$ & 2 & 0 & 183,779 \\
\hline $\mathrm{P}$ & 27,971 & $1.29 \mathrm{E}+08$ & $2.58 \mathrm{E}+07$ & 2 & 6,135 & 49,808 \\
\hline
\end{tabular}

$\bar{y}:$ arithmetic mean of the concentration data,

BMS: "between mean squares" from the one-way analysis of variance,

$\hat{\sigma}_{\bar{y}}^{2}$ : estimated variance of $\bar{y}$,

df: degrees of freedom associated with BMS,

L: lower limit to the $95 \%$ confidence interval on the mean, and

$U$ : upper limit to the $95 \%$ confidence interval on the mean. 
Table 7-3. Water Leach Inventory Statistics $(\mu \mathrm{g} / \mathrm{g})$.

\begin{tabular}{|c|c|c|c|c|c|c|}
\hline \multicolumn{7}{|c|}{ Excluding Drainable Liquid Composites } \\
\hline Analyte & $\bar{y}$ & BMS & $\hat{\sigma}_{\bar{y}}^{2}$ & $d f$ & $\mathrm{~L}$ & U \\
\hline Al & 521 & $1.43 E+05$ & $2.87 E+04$ & 2 & 0 & 1,250 \\
\hline $\mathrm{Ca}$ & 338 & $7.04 E+03$ & $1.41 E+03$ & 2 & 176 & 499 \\
\hline $\mathrm{Fe}$ & 1,168 & $3.66 E+05$ & $7.31 E+04$ & 2 & 5 & 2,332 \\
\hline $\mathrm{Na}$ & 88,541 & $1.31 E+09$ & $2.62 E+08$ & 2 & 18,838 & 158,244 \\
\hline $\mathrm{Na} \mathrm{\#}$ & & & & & & \\
\hline$\overline{N i}$ & 679 & $1.38 E+05$ & $2.76 E+04$ & 2 & 0 & 1,395 \\
\hline $\mathrm{Pb}$ & NA & NA & NA & NA & NA & NA \\
\hline $\bar{U}$ & 2,166 & $9.87 E+06$ & $1.97 \mathrm{E}+06$ & 2 & 0 & 8,211 \\
\hline$P$ & 10,108 & $6.72 \mathrm{E}+07$ & $1.34 E+07$ & 2 & 0 & 25,886 \\
\hline \multicolumn{7}{|c|}{ Including Drainable Liquid Composites } \\
\hline Analyte & $\bar{y}$ & BMS & $\hat{\sigma}_{\bar{y}}^{2}$ & $\mathrm{df}$ & $\mathrm{L}$ & u \\
\hline Al & 521 & $1.43 E+05$ & $2.87 E+04$ & 2 & 0 & 1,250 \\
\hline $\mathrm{Ca}$ & 253 & $2.57 E+04$ & $3.67 E+03$ & 2 & 0 & 513 \\
\hline $\mathrm{Fe}$ & 1,092 & $4.20 E+05$ & $4.68 E+04$ & 2 & 161 & 2,022 \\
\hline $\mathrm{Na}$ & 84,078 & $1.34 E \div 09$ & $1.49 E+08$ & 2 & 31477 & 136,679 \\
\hline \multicolumn{7}{|l|}{$\mathrm{Na} \mathrm{\#}$} \\
\hline $\mathrm{Ni}$ & 662 & $1.65 E+05$ & $1.84 E+04$ & 2 & 79 & 1,245 \\
\hline $\mathrm{Pb}$ & $\mathrm{NA}$ & NA & NA & $N A$ & $\mathrm{NA}$ & NA \\
\hline $\bar{U}$ & 1,673 & $1.11 E+07$ & $1.23 E+06$ & 2 & 0 & 6,442 \\
\hline$P$ & 7,350 & $1.07 E+08$ & $1.18 E+07$ & 2 & 0 & 22,153 \\
\hline
\end{tabular}

\# excluding outlier data result.

$\bar{y}$ : arithmetic mean of the concentration data,

BMS: "between mean squares" from the one-way analysis of variance,

$\hat{\sigma}_{\overline{:}}^{2}$ : estimated variance of $\bar{y}$,

df: degrees of freedom associated with BMS,

L: lower limit to the $95 \%$ confidence interval on the mean

$U$ : upper limit to the $95 \%$ confidence interval on the mean. 
Table 7-4. Radiochemistry Statistics $(\mu \mathrm{Ci} / \mathrm{g})$.

\begin{tabular}{|l|r|c|c|c|r|r|}
\hline \multicolumn{1}{|c|}{ Element } & \multicolumn{1}{c|}{$\bar{y}$} & BMS & $\hat{\sigma}_{\bar{y}}^{2}$ & df & \multicolumn{1}{c|}{$\mathrm{L}$} & \multicolumn{1}{c|}{$U$} \\
\hline${ }^{137} \mathrm{CS}$ & 747 & $8.38 \mathrm{E}+03$ & $1.68 \mathrm{E}+03$ & 2 & 571 & 924 \\
\hline${ }^{90} \mathrm{Sr}$ & 2,189 & $4.74 \mathrm{E}+06$ & $9.48 \mathrm{E}+05$ & 2 & 0 & 6,380 \\
\hline $\mathrm{U}_{\mathrm{FL}}(\mu \mathrm{g} / \mathrm{g})$ & 68,600 & $3.89 \mathrm{E}+09$ & $1.30 \mathrm{E}+09$ & 1 & 0.0 & 525,911 \\
\hline${ }^{239 / 240} \mathrm{Pu}$ & 0.06 & 0.013323 & 0.002665 & 2 & 0.0 & 0.28 \\
\hline${ }^{238} \mathrm{Pu}$ & 0.06 & 0.025023 & 0.005005 & 2 & 0.00 & 0.37 \\
\hline
\end{tabular}

$\mathrm{FL}=$ laser fluorimetry

Table 7-5. Ion Chromatography Anion Statistics $(\mu \mathrm{g} / \mathrm{g})$.

\begin{tabular}{|l|r|r|r|r|r|r|}
\hline Compound & \multicolumn{1}{|c|}{$\bar{y}$} & \multicolumn{1}{c|}{ BMS } & $\hat{\sigma}_{\bar{y}}^{2}$ & df & \multicolumn{1}{c|}{ L } & \multicolumn{1}{c|}{} \\
\hline Chloride & 980 & 109,000 & 21,800 & 2 & 345 & 1,615 \\
\hline Nitrite & 47,200 & $2.99 \mathrm{E}+08$ & $5.98 \mathrm{E}+07$ & 2 & 13,930 & 80,470 \\
\hline Nitrate & 62,000 & $5.95 \mathrm{E}+08$ & $1.19 \mathrm{E}+08$ & 2 & 15,080 & 108,921 \\
\hline Phosphate & 30,760 & $5.86 \mathrm{E}+08$ & $1.17 \mathrm{E}+08$ & 2 & 0 & 77,337 \\
\hline Sulfate & 12,040 & $2.09 \mathrm{E}+07$ & $4.19 \mathrm{E}+06$ & 2 & 3,237 & 20,843 \\
\hline
\end{tabular}

$\bar{y}$ : arithmetic mean of the concentration data,

BMS: "between mean squares" from the one-way analysis of variance,

$\hat{\sigma}_{\overline{.}}^{2}:$ estimated variance of $\bar{y}$,

df: degrees of freedom associated with BMS,

$L$ : lower 7 imit to the $95 \%$ confidence interval on the mean, and

U: upper limit to the $95 \%$ confidence interval on the mean.

The radiochemistry $U$ confidence $l$ imits should be viewed with caution. This interval is based on three sample results from Cores 34 and 36 . The CI for $\bar{y}$ uses a t-statistic with one degree of freedom, which inflates the CI width due to the uncertainty of the $U$ results.

\subsection{HOMOGENIZATION TESTS}

A second task, directed by WHC-EP-0210 Rev 1 (Winters et al. 1990a) to core samples from tank 241-C-112, was to evaluate the ability of the 325 Analytical Chemistry Laboratory to homogenize core subsegments. Each subsegment (from Cores 34,35 , and 36 ) was homogenized and arbitrarily divided into two parts (top and bottom). One subsample was obtained from each part. Two al iquots were taken from each subsample and prepared for chemical analysis. The homogenization test data described above are tabulated in Appendix B. ICP acid digestion analyses were conducted on the aliquots for the following analytes: aluminum, iron, sodium, nickel, lead, uranium, and phosphorus. 
Due to the structure of the data, a hierarchical model can be $f$ it to the data. This model is used to separate different components of variability in the data. The total variability in the data is composed of three separate components: one due to variability between the segments; one due to the variability between samples from the homogenized material $\left(\sigma_{h}^{2}\right)$ within the segments (this component of variability is referred to as being due to homogenization); and one due to analytical error. The analytical error is the variance component that measures the variability between duplicate measurements from aliquots prepared from the same sample. Appendix $B$ contains a description of the hierarchical model. From the analysis of variance (ANOVA) results of the hierarchical model, a test can be conducted to determine if $\sigma_{h}^{2}$ is significantly greater than zero. If $\sigma_{h}^{2}$ is significantly greater than zero, then it can be concluded that the laboratory does not have the ability to homogenize core segments. If it cannot be concluded that $\sigma_{h}^{2}$ is significantly greater than zero, then the laboratory does have the ability to homogenize core segments. The F-statistic $p$-value from the ANOVA was used to test if $\sigma_{h}^{2}$ is greater than zero. If the p-value is smaller than 0.05 , it is concluded that the $\sigma_{h}^{2}>0$.

The results of the homogenization test are given in Table 7-6. For all analytes tested (aluminum, calcium, iron, sodium, nickel, phosphorus, lead, uranium), the p-value from the F-test was greater than 0.05 . It cannot be concluded that the variability between the sampled locations of the mixed subsegments is significantly different from zero. The overall conclusion is that the ability of the 325 Analytical Chemistry Laboratory to homogenize core samples is satisfactory for this material. It is interesting to note that segment-to-segment variability always accounts for more than 77 percent of the total variability, and analytical error claims most of the rest. The percent of the variability due to the homogenization is usually less than l percent.

Table 7-6. Homogenization Test Results.

\begin{tabular}{|l|c|c|c|c|}
\hline \multirow{2}{*}{ Analyte } & \multirow{2}{*}{$p$-value } & \multicolumn{3}{|c|}{ \% Variability due to: } \\
\cline { 3 - 5 } & & segment & homogenization & analytical \\
\hline $\mathrm{Al}$ & 0.65 & 94.82 & 0.00 & 5.18 \\
$\mathrm{Ca}$ & 0.10 & 99.45 & 0.34 & 0.21 \\
$\mathrm{Fe}$ & 0.58 & 77.10 & 0.00 & 22.90 \\
$\mathrm{Na}$ & 0.72 & 92.95 & 0.00 & 7.05 \\
$\mathrm{Ni}$ & 0.42 & 99.17 & 0.04 & 0.79 \\
$\mathrm{P}$ & 0.26 & 96.55 & 0.74 & 2.71 \\
$\mathrm{~Pb}$ & 0.22 & 99.73 & 0.87 & 2.40 \\
$\mathrm{U}$ & 0.08 & 99.55 & 0.21 & 0.24 \\
\hline
\end{tabular}

An observation with a large residual was found for Core 34 , subsegment $2 D$ iron data. The removal of this observation did not change the results of the homogenization tests. 


\subsection{COMPARISON BETWEEN THE SIMULATED CORE COMPOSITE AND THE CORE COMPOSITE}

Another task directed by WHC-EP-0210 (Winters et al. 1990a,b) was to evaluate the ability of the 325 Analytical Chemistry Laboratory to prepare core composite samples from the individual subsegment samples. A core composite sample was formed by combining equally weighted individual samples from each homogenized subsegment in the core. The core composite was then homogenized and a sample and duplicate were taken. A simulated core composite was constructed to compare with the core composite samples. The simulated core composite is the mean of the results from the chemical analysis of the individual aliquots from each segment.

For the chemical analysis methods reporting subsegment results (ICP potasium hydroxide fusion dissolution, radiochemistry, IC), Core 34 did not have core composite duplicate results reported. For this reason, the method used to compare the core composite with the simulated core composite for Core 36 is slightly different than the method used for core 34 .

\subsubsection{Core 36 Statistical Methods}

The comparison for Core 36 is made by computing a CI on the difference between the twc means. If zero is in the CI, the simulated core composite mean cannot be statistically distinguished from the core composite sample mean. If zero is not in the CI, the two means are significantly different.

The CI on the difference between the simulated core composite and core composite mean is $(L, U)$, where the lower $(L)$ and $(U)$ values are

$$
L=\left(\bar{y}_{w}-\bar{y}_{c}\right)-t \sqrt{\hat{\sigma}^{2}\left(\bar{y}_{w}-\bar{y}_{c}\right)}, \quad U=\left(\bar{y}_{w}+\bar{y}_{c}\right)-t \sqrt{\hat{\sigma}^{2}\left(\bar{y}_{w}-\bar{y}_{c}\right)}
$$

and where

$$
\begin{aligned}
\bar{y}_{w}: & \text { subsegment data mean (simulated core composite) } \\
\bar{y}_{c}: & \text { core composite sample mean } \\
t: & 97.5 \text { percentile point from Student's } t \text { distribution } \\
\hat{\sigma}^{2}\left(\bar{y}_{w}-\bar{y}_{c}\right): & \text { estimated variance of the difference. }
\end{aligned}
$$

Appendix $B$ contains a discussion on how $\hat{\sigma}^{2}\left(\bar{y}_{w}-\bar{y}_{c}\right)$ is calculated. The calculation of $\hat{\sigma}^{2}\left(\bar{y}_{4}-\bar{y}_{c}\right)$ uses the data from all three cores because of the limited data available. The " $t$ " has degrees of freedom (df) associated with it, which was calculated using Satterwaite's approximation (Snedecor and Cochran 1980). 


\subsubsection{Core 34 Statistical Methods}

A CI for $\bar{y}_{p}$ is calculated to make the comparison between the core composite and the simulated core composite. If the composite sample result is contained within the CI, then $\bar{y}_{w}$ cannot be statistically distinguished from the core composite sample result. If the core composite sample results are not contained within the $C I$, then $\bar{y}_{w}$ and the core composite sample are statistically different.

The CI on $\bar{y}_{w}$ is $(L, U)$ where the lower $(L)$ and $(U)$ values are

$$
L=\bar{y}_{w}-t \sqrt{\hat{\sigma}^{2}\left(\bar{y}_{w}\right)}, \quad U=\bar{y}_{w}+t \sqrt{\hat{\sigma}^{2}\left(\bar{y}_{w}\right)}
$$

and where $\hat{\sigma}^{2}\left(\bar{y}_{w}\right)$ is the estimated variance of $\bar{y}_{w}$. Appendix $B$ contains a discussion of how $\hat{\sigma}^{2}\left(\bar{y}_{w}\right)$ is calculated.

\subsubsection{Results from Cores 34 and 36}

Tables 7-7 and 7-8 present the results of the simulated core composites mean versus the core composite mean for Cores 34 and 36 respectively. Appendix $B$ contains figures of the segment and core composite data for all three cores, which may aid in the understanding the results from the tables.

Only three analytes (sodium, chloride, sulfate) had composite samples that were outside of the $\bar{y}_{w}$ confidence interval for Core 34 . In all three cases, the composite sample exceeds the upper limit of the CI. For Core 36 , all the CIs of the difference $\bar{y}_{w}-\bar{y}_{c}$ contained zero, indicating that there was no significant difference between $\bar{y}_{w}$ and $\bar{y}_{c}$. Overall, the simulated core composite could be statistically distinguished from the mean in 89 percent of the cases tested. On this basis, it can be concluded that the 325 Analytical Chemistry Laboratory is able to make core composites satisfactorily.

\subsection{SPATIAL VARIABILITY AND ANALYTICAL ERROR ESTIMATION}

Using the hierarchical structure of the data (cores selected randomly and two aliquots selected per core composite), the spatial variability and the analytical error can be separated from each other. The spatial variability is the variability from core composite to core composite. The analytical error, as it is called here, is not only true analytical error. Confounded with it is segment homogenization and sampling variability. Variability from all three of these sources will be referred to as analytical error.

The size of the analytical error compared to the spatial variability has an impact on the analyte concentration CIs from Section 3.0. The variance used in the CI calculations is a linear function of estimates of spatial and analytical variability. Because the size of the analytical error can potentially be controlled, this comparison is an interesting factor. 
Table 7-7. Segment vs. Composite Statistics for Core 34 .

\begin{tabular}{|c|c|c|c|c|c|c|}
\hline \multirow{2}{*}{ Analyte } & \multirow{2}{*}{$\bar{y}_{w}$} & \multirow{2}{*}{$\hat{\sigma}^{2}\left(\bar{y}_{w}\right)$} & \multirow{2}{*}{ Composite } & \multirow{2}{*}{$d f *$} & \multicolumn{2}{|c|}{$95 \%$ CI for $\bar{y}_{w}$} \\
\hline & & & & & $L$ & $U$ \\
\hline Al & 23,549 & $5.24 E+07$ & 29,798 & 2 & 0 & 54,708 \\
\hline $\mathrm{Ca}$ & 25,894 & $1.89 E+07$ & 28,984 & 8 & 15,864 & 35,923 \\
\hline $\mathrm{Fe}$ & 13,295 & $1.95 E+07$ & 22,848 & 8 & 3,107 & 23,483 \\
\hline $\mathrm{Na} \mathrm{\#}$ & 87,128 & $1.35 E+07$ & 114,891 & 9 & 78,806 & 95,451 \\
\hline $\mathrm{Pb}$ & 3,220 & $1.10 E+06$ & 3,326 & 3 & 0 & 6,559 \\
\hline U & 20,098 & $6.98 E+08$ & 14,369 & 5 & 0 & 88,039 \\
\hline$P$ & 17,318 & $6.50 E+06$ & 21,956 & 6 & 11,076 & 23,561 \\
\hline Chloride \# & 963 & 4,464 & 1,300 & 6 & 799 & 1,126 \\
\hline Nicrite & 51,875 & $1.88 E+07$ & 62,000 & 5 & 40,740 & 63,010 \\
\hline Nitrate & 68,125 & $2.80 E+07$ & 80,000 & 5 & 54,528 & 81,722 \\
\hline Phosphate & 13,200 & $3.37 E+07$ & 19,100 & 7 & 0 & 26,922 \\
\hline Sulfate \# & 12,587 & $8.57 E+05$ & 15,600 & 6 & 10,322 & 14,852 \\
\hline Cs-137 & 539 & 17,666 & 750 & 9 & 238 & 840 \\
\hline$S r-90$ & 2,456 & $5.37 E+05$ & 3,510 & 4 & 422 & 4,490 \\
\hline
\end{tabular}

\# Significant difference between segment data and composite.

units: $\mu \mathrm{g} / \mathrm{g}: \mathrm{Al}, \mathrm{C} \exists, \mathrm{Fe}, \mathrm{Na}, \mathrm{Pb}, \mathrm{U}, \mathrm{P}$, chloride, nitrite, nitrate, phosphate, sulfate

$\mu \mathrm{Ci} / \mathrm{g}: \quad \mathrm{Cs}-137, \mathrm{Sr}-90$ 
Table 7-8. Segment vs. Composite Statistics for Core 36.

\begin{tabular}{|c|c|c|c|c|c|c|}
\hline \multirow{2}{*}{ Analyte } & \multirow{2}{*}{$\bar{y}_{w}$} & \multirow{2}{*}{$\bar{y}_{c}$} & \multirow{2}{*}{$\hat{\sigma}^{2}\left(\bar{y}_{w}-\bar{y}_{c}\right)$} & \multirow{2}{*}{$d f^{*}$} & \multicolumn{2}{|c|}{$95 \%$ CI for $\bar{y}_{w}-\bar{y}_{c}$} \\
\hline & & & & & L & $U$ \\
\hline Al & 4,948 & 6,410 & $4.29 E+08$ & 3 & $-67,364$ & 64,439 \\
\hline $\mathrm{Ca}$ & 15,484 & 20,391 & $5.17 E+07$ & 5 & $-23,393$ & 13,580 \\
\hline $\mathrm{Fe}$ & 18,355 & 26,012 & $3.76 E+07$ & 7 & $-22,158$ & 6,844 \\
\hline $\mathrm{Na}$ & 92,724 & 120,730 & $4.35 \mathrm{E}+08$ & 2 & $-117,756$ & 61,744 \\
\hline $\mathrm{Pb}$ & 1,788 & 1,049 & $4.36 E+06$ & 3 & $-5,902$ & 7,379 \\
\hline U & 96,380 & 104,910 & $2.13 E+09$ & 4 & $-136,748$ & 119,688 \\
\hline$P$ & 24,733 & 36,761 & $7.10 E+07$ & 2 & $-48,288$ & 24,232 \\
\hline Chloride & 783 & 1,050 & 58,964 & 2 & $-1,312$ & 778 \\
\hline Nitrite & 40,750 & 52,500 & $1.68 \mathrm{E}+08$ & 3 & $-53,025$ & 29,525 \\
\hline Nitrate & 55,667 & 71,500 & $3.25 E+08$ & 2 & $-93,463$ & 61,796 \\
\hline Phosphate & 28,858 & 49,500 & $3.27 E+08$ & 2 & $-98,414$ & 57,130 \\
\hline Sulfate & 10,600 & 13,700 & $1.13 E+07$ & 2 & $-17,578$ & 11,377 \\
\hline Cs-137 & 559 & 793 & 21,857 & 11 & -559 & 92 \\
\hline$S r-90$ & 384 & 508 & $2.90 E+06$ & 3 & $-7,462$ & 7,214 \\
\hline
\end{tabular}

\# significant difference between segment data and composite units: $\mu \mathrm{g} / \mathrm{g}$ : $\mathrm{Al}, \mathrm{Ca}, \mathrm{Fe}, \mathrm{Na}, \mathrm{Pb}, \mathrm{U}, \mathrm{P}$, chloride, nitrite, nitrate, phosphate, sulfate

$\mu \mathrm{Ci} / \mathrm{g}: \quad \mathrm{Cs}-137, \mathrm{Sr}-90$ 
Estimates of the spatial variability $\left(\hat{\sigma}_{s}^{2}\right)$ and analytical error $\left(\hat{\sigma}_{a}^{2}\right)$ were obtained for each analyte by solving a system of equations using ANOVA results and expected mean squares (Snedecor and Cochran 1980). Snedecor and Cochran (1980) al so explain how CIs for $\sigma_{s}^{2}$ and $\sigma_{a}^{2}$ were obtained. An approximate CI for $\sigma_{s}^{2}$ was obtained using the ANOVA results and four F-statistic values. Exact CIs were obtained for $\sigma_{a}^{2}$ using $\hat{\sigma}_{a}^{2}$ and a chi-square statistic. Tables 7-9, 7-10, 7-11, 7-12, arid 7-13 contain estimates and 95 percent CIs for $\sigma_{s}^{2}$ and $\sigma_{a}^{2}$ for all 14 analytes and chemical analysis methods. Using the variance component estimation methods described above, it is possible to obtain negative estimates. When negative variance components estimates were obtained they were set equal to zero. Lower limits $(L)$ on the 95 percent CIs were also set equal to zero if the were negative.

Including or excluding the DLC results greatly affected $\hat{\sigma}_{s}^{2}$ and $\hat{\sigma}_{a}^{2}$ for the acid digestion and water leach ICP analyses (refer to Tables 7-9 and 7-10). When the DLCs were excluded, $\hat{\sigma}_{s}^{2}$ was generally larger than $\hat{\sigma}_{a}^{2}$. When the DLCs were included, $\hat{\sigma}_{\mathrm{a}}^{2}$ was generally of the same magnitude or larger than $\hat{\sigma}_{\mathrm{s}}^{2}$. For the radiochemistry analysis, an estimate and approximate CI for $\sigma_{s}^{2}$ were not obtained due to the small number of data reported.

In general, the upper limits $(U)$ on the approximate 95 percent CIs for $\sigma_{s}^{2}$ were larger than the 95 percent C.I upper limits for $\sigma_{0}^{2}$ (88 percent of the cases). From this result it can be generally concluded that the spatial variability $\left(\sigma_{s}^{2}\right)$ is of the same magnitude or larger than the analytical error $\sigma_{\mathrm{a}}^{2}$. 
Table 7-9. Acid Digestion Spatial and Analytical Error Estimates.

\begin{tabular}{|c|c|c|c|c|c|c|}
\hline \multicolumn{7}{|c|}{ Excluding Drainable Liquid Composites } \\
\hline \multirow{2}{*}{ Analyte } & \multirow[t]{2}{*}{$\hat{\sigma}_{\mathrm{s}}^{2}$} & \multirow[t]{2}{*}{$\hat{\sigma}_{\mathrm{a}}^{2}$} & \multicolumn{2}{|c|}{$95 \%$ CI for $\hat{\sigma}_{s}^{2} *$} & \multicolumn{2}{|c|}{$95 \%$ CI for $\hat{\sigma}_{a}^{2}$} \\
\hline & & & $L$ & $U$ & L & U \\
\hline Al & $3.67 E+08$ & $3.10 E+07$ & $9.69 E+07$ & $7.44 E+09$ & $9.93 E+06$ & $4.30 E+08$ \\
\hline $\mathrm{Ca}$ & $2.49 E+07$ & $1.44 E+06$ & $7.11 E+06$ & $4.98 E+08$ & $4.62 E+05$ & $1.20 E+07$ \\
\hline $\mathrm{Fe}$ & 0 & $2.76 E+07$ & 0 & $2.43 E+08$ & $8.85 E+06$ & $3.83 E+08$ \\
\hline $\mathrm{Na}$ & $2.66 E+08$ & $2.39 E+07$ & $6.91 E+07$ & $5.42 E+09$ & $7.66 E+06$ & $3.32 E+08$ \\
\hline $\mathrm{Ni}$ & $1.55 E+07$ & $1.06 E+06$ & $4.28 E+06$ & $3.11 E+08$ & $3.41 E+05$ & $1.48 E+07$ \\
\hline $\mathrm{Pb}$ & $2.28 E+06$ & 24,113 & $7.43 E+05$ & $4.47 E+07$ & 7,737 & $3.35 E+05$ \\
\hline U & $1.56 E+09$ & $1.10 E+08$ & $4.28 E+08$ & $3.14 E+10$ & $3.54 E+07$ & $1.53 E+09$ \\
\hline$P$ & $4.52 E+07$ & $3.83 E+06$ & $1.19 E+07$ & $9.17 E+08$ & $1.23 E+06$ & $5.32 E+07$ \\
\hline \multicolumn{7}{|c|}{ Including Drainable Liquid Composites } \\
\hline \multirow{2}{*}{ Analyte } & \multirow{2}{*}{$\hat{\sigma}_{s}^{2}$} & \multirow{2}{*}{$\hat{\sigma}_{a}^{2}$} & \multicolumn{2}{|c|}{$95 \%$ CI for $\dot{\sigma}_{s}^{2} *$} & \multicolumn{2}{|c|}{$95 \%$ CI for $\hat{\sigma}_{a}^{2}$} \\
\hline & & & L & $U$ & $L$ & U \\
\hline Al & $3.67 E+08$ & $3.10 E+07$ & $9.69 E+07$ & $7.44 E+09$ & $9.93 E+06$ & $4.30 E+08$ \\
\hline $\mathrm{Ca}$ & 12,440 & $8.34 E+07$ & 0 & $4.82 E+08$ & $3.65 E+07$ & $3.46 E+08$ \\
\hline $\mathrm{Fe}$ & 0 & $1.55 E+08$ & 0 & $2.73 E+08$ & $6.77 E+07$ & $6.41 E+08$ \\
\hline $\mathrm{Na}$ & $2.31 E+08$ & $3.28 E+07$ & $4.63 E+07$ & $4.69 E+09$ & $1.43 E+07$ & $1.36 E+08$ \\
\hline $\mathrm{Ni}$ & 0 & $5.82 E+07$ & 0 & $1.00 E+08$ & $2.55 E+07$ & $2.41 E+08$ \\
\hline $\mathrm{Pb}$ & $2.28 E+06$ & 24,112 & $7.43 E+05$ & $4.47 E+07$ & $7,736.657$ & $3.35 E+05$ \\
\hline U & $9.72 E+08$ & $9.39 E+08$ & 0 & $2.44 E+10$ & $4.11 E+08$ & $3.89 E+09$ \\
\hline $\mathrm{P}$ & $7.36 E+07$ & $6.70 E+07$ & 0 & $1.82 E+09$ & $2.93 E+07$ & $2.77 E+08$ \\
\hline
\end{tabular}

*Approximate $95 \%$ confidence interval (CI). 
Table 7-10. Water Leach Spatial and Analytical Error Estimates.

\begin{tabular}{|c|c|c|c|c|c|c|}
\hline \multicolumn{7}{|c|}{ Excluding Drainable Liquid Composites } \\
\hline \multirow{2}{*}{ Analjte } & \multirow{2}{*}{$\hat{\sigma}_{s}^{2}$} & \multirow{2}{*}{$\hat{\sigma}_{\mathrm{a}}^{2}$} & \multicolumn{2}{|c|}{$95 \%$ CI for $\hat{\sigma}_{s}^{2} *$} & \multicolumn{2}{|c|}{$95 \%$ CI for $\hat{\sigma}_{a}^{2}$} \\
\hline & & & $\mathbf{L}$ & $U$ & $\mathrm{~L}$ & U \\
\hline Al & 70,595 & 30,458 & 0 & $1.73 E+06$ & 8,254 & 120,388 \\
\hline $\mathrm{Ca}$ & 0 & 37,798 & 0 & 61,606 & 10,243 & 149,400 \\
\hline $\mathrm{Fe}$ & $2.26 E+05$ & 3,433 & $7.28 E+04$ & $4.45 E+06$ & 930 & 13,569 \\
\hline $\mathrm{Na}$ & $5.01 E+08$ & $5.11 E+08$ & 0 & $1.57 E+10$ & $1.38 E+08$ & $2.02 E+09$ \\
\hline $\mathrm{Ni}$ & 85,597 & 1,287 & $2.76 E+04$ & $1.68 E+06$ & 349 & 5,087 \\
\hline $\mathrm{Pb}$ & NA & NA & NA & $N A$ & NA & NA \\
\hline U & $4.55 E+06$ & $2.60 E+06$ & 0 & $1.19 E+08$ & $7.03 E+05$ & $1.03 E+07$ \\
\hline$p$ & $3.50 E+07$ & $1.13 E+07$ & $2.27 E+06$ & $8.12 E+08$ & $3.06 E+06$ & $4.46 E+07$ \\
\hline \multicolumn{7}{|c|}{ Including Drainable Liquid Composites } \\
\hline \multirow[t]{2}{*}{ Analyte } & \multirow[t]{2}{*}{$\hat{\sigma}_{s}^{2}$} & \multirow[t]{2}{*}{$\hat{\sigma}_{a}^{2}$} & \multicolumn{2}{|c|}{$95 \%$ CI for $\hat{\sigma}_{\mathrm{s}}^{2} *$} & \multicolumn{2}{|c|}{$95 \%$ CI for $\hat{\sigma}_{a}^{2}$} \\
\hline & & & $L$ & $U$ & $\mathrm{~L}$ & $U$ \\
\hline Al & 70,595 & 30,458 & 0 & $1.73 E+06$ & 8,254 & $1.20 E+05$ \\
\hline $\mathrm{Ca}$ & 0 & 41,181 & 0 & $2.29 E+05$ & 14,840 & $3.40 E+05$ \\
\hline $\mathrm{Fe}$ & $1.38 E+05$ & 22,384 & 25,347 & $2.83 E+06$ & 9,327 & $1.08 E+05$ \\
\hline $\mathrm{Na}$ & $3.86 E+08$ & $2.31 E+08$ & 0 & $9.00 E+09$ & $9.63 E+07$ & $1.12 e+09$ \\
\hline $\mathrm{Ni}$ & 54,992 & 6,588 & 12,290 & $1.11 E+06$ & 2,745 & $3.19 E+04$ \\
\hline $\mathrm{Pb}$ & NA & NA & NA & NA & NA & NA \\
\hline U & $3.50 E+06$ & $9.30 E+05$ & $3.11 E+05$ & $7.43 E+07$ & $3.87 E+05$ & $4.50 E+06$ \\
\hline$P$ & $3.52 E+07$ & $4.94 E+06$ & $7.18 E+06$ & $7.17 E+08$ & $2.06 E+06$ & $2.39 E+07$ \\
\hline
\end{tabular}

*Approximate $95 \%$ confidence interval (CI). 
Table 7-11. Potassium Hydroxide/Nickel Fusion Dissolution Spatial and Analytical Error Estimates.

\begin{tabular}{|c|c|c|c|c|c|c|}
\hline \multirow{2}{*}{ Analyte } & \multirow{2}{*}{$\hat{\sigma}_{\mathrm{s}}^{2}$} & \multirow{2}{*}{$\hat{\sigma}_{\mathrm{a}}^{2}$} & \multicolumn{2}{|c|}{$95 \%$ CI for $\hat{\sigma}_{s}^{2} *$} & \multicolumn{2}{|c|}{$95 \%$ CI for $\hat{\sigma}_{a}^{2}$} \\
\hline & & & $L$ & $U$ & $L$ & $U$ \\
\hline Al & $4.70 E+08$ & $5.67 E+05$ & $1.57 E+08$ & $9.17 E+09$ & $1.54 E+05$ & $2.24 E+07$ \\
\hline$\overline{\mathrm{Ca}}$ & $4.09 E+07$ & $1.56 E+05$ & $1.37 \mathrm{E}+07$ & $7.99 E+08$ & 42,269 & $6.16 E+06$ \\
\hline $\mathrm{Fe}$ & $1.65 E+07$ & $9.81 E+06$ & $7.56 E+06$ & $4.34 E+08$ & $2.66 E+06$ & $3.88 E+08$ \\
\hline $\mathrm{Na}$ & $5.24 E+08$ & $3.96 E+06$ & $1.76 E+08$ & $1.03 E+10$ & $1.07 E+06$ & $1.57 E+08$ \\
\hline $\mathrm{Ni}$ & NA & NA & NA & NA & NA & NA \\
\hline$\overline{\mathrm{Pb}}$ & $3.98 E+06$ & $1.47 E+05$ & $1.36 \mathrm{E}+06$ & $7.92 \quad E+07$ & $3.99 E+04$ & $5.82 E+06$ \\
\hline$U$ & $1.78 E+09$ & $1.64 E+07$ & $5.99 E+08$ & $3.49 E+10$ & $4.44 \quad E+06$ & $6.48 E+08$ \\
\hline$P$ & $8.04 E+07$ & $1.37 E+05$ & $2.69 E+07$ & $1.57 E+09$ & 37,210 & $5.43 E+06$ \\
\hline
\end{tabular}

*Approximate $95 \%$ confidence interval (CI).

Table 7-12. Radiochemistry Spatial and Analytical Error Estimates.

\begin{tabular}{|l|r|r|r|r|r|r|}
\hline \multirow{2}{*}{ Analyte } & \multirow{2}{*}{$\hat{\sigma}_{\mathrm{s}}^{2}$} & \multirow{2}{*}{$\hat{\sigma}_{\mathrm{a}}^{2}$} & \multicolumn{2}{|c|}{$95 \% \mathrm{CI}$ for $\hat{\sigma}_{\mathrm{s}}^{2} *$} & \multicolumn{2}{c|}{$95 \% \mathrm{C}$. I. for $\dot{\sigma}_{a}^{2}$} \\
\cline { 5 - 8 } & & & $\mathrm{L}$ & $\mathrm{U}$ & $\mathrm{L}$ & $U$ \\
\hline${ }^{137} \mathrm{Cs}$ & 4,949 & 463 & 1,752 & $1.02 \mathrm{E}+05$ & 125 & 18,281 \\
\hline${ }^{90} \mathrm{Sr}$ & $3.56 \mathrm{E}+06$ & 1,360 & $9.91 \mathrm{E}+05$ & $5.78 \mathrm{E}+07$ & 369 & 53,767 \\
\hline$U$ & 0 & $2.76 \mathrm{E}+07$ & & & $7.47 \mathrm{E}+06$ & $1.09 \mathrm{E}+09$ \\
\hline${ }^{239 / 240} \mathrm{Pu}$ & $8.29 \mathrm{E}-03$ & $5.4 \mathrm{E}-05$ & $2.78 \mathrm{E}-03$ & $1.62 \mathrm{E}-01$ & $1.5 \mathrm{E}-05$ & $2.13 \mathrm{E}-03$ \\
\hline${ }^{238} \mathrm{Pu}$ & $1.56 \mathrm{E}-02$ & $3.2 \mathrm{E}-05$ & $5.23 \mathrm{E}-03$ & $3.05 \mathrm{E}-01$ & $0.9 \mathrm{E}-05$ & $1.27 \mathrm{E}-03$ \\
\hline
\end{tabular}

*Approximate $95 \%$ confidence interval (CI).

Table 7-13. Ion Chromatography Anion Spatial and Analytical Error Estimates.

\begin{tabular}{|c|c|c|c|c|c|c|}
\hline \multirow{2}{*}{ Analyte } & \multirow{2}{*}{$\hat{\sigma}_{s}^{2}$} & \multirow{2}{*}{$\hat{\sigma}_{\mathrm{a}}^{2}$} & \multicolumn{2}{|c|}{$95 \%$ CI for $\hat{\sigma}_{s}^{2} *$} & \multicolumn{2}{|c|}{$95 \%$ CI for $\hat{\sigma}_{a}^{2}$} \\
\hline & & & $L$ & $U$ & $L$ & $U$ \\
\hline Chloride & 52,500 & 25,000 & 22,784 & $1.31 E+06$ & 6,775 & $9.88 E+05$ \\
\hline Nitrite & $1.04 E+08$ & $1.33 E+08$ & $6.25 E+07$ & $3.56 E+09$ & $3.59 E+07$ & $5.24 E+09$ \\
\hline Nitrate & $2.21 E+08$ & $2.41 E+08$ & $1.24 E+08$ & $7.09 E+09$ & $6.52 E+07$ & $9.51 E+09$ \\
\hline Phosphate & $2.97 E+08$ & $1.10 E+08$ & $1.22 E+08$ & $7.07 E+09$ & $2.99 E+07$ & $4.36 E+09$ \\
\hline Sulfate. & $9.17 E+06$ & $6.25 E+06$ & $4.37 E+06$ & $2.51 E+08$ & $1.69 E+06$ & $2.47 E+08$ \\
\hline
\end{tabular}

*Approximate $95 \%$ confidence interval (CI). 


\section{WHC-EP-0640}

This page intentionally left blank. 


\subsection{CONCLUSIONS AND RECOMMENDATIONS}

\subsection{ANALYTICAL RESULTS}

Analyses of the waste show a very small number of analytes comprising a large portion of the waste. Water is the single largest analyte, making up 58.4 percent of the total mass. Seven elements (aluminum, calcium, iron, sodium, nickel, phosphorus, and uranium) constitute approximately 22.3 percent of the solids mass. They also represent over 95 percent of the total cations. Two anions $\left(\mathrm{NO}_{2}^{-}\right.$and $\left.\mathrm{NO}_{3}^{-}\right)$constitute approximately 10 percent of the mass. The fraction of the total anions that nitrate and nitrite represent cannot be adequately determined because the analytical method measured only soluble anions. The total cyanide content was measured and found to be less than 1 percent (dry basis) in each core and for the tank as a whole.

The only significant gamma emitter found in the waste was ${ }^{137} \mathrm{Cs}$. Although ${ }^{60} \mathrm{Co}$ was also precipitated during the scavenging process, it has decayed below any level of concern and does not contribute to the heat load of the tank. No meaningful regional concentrations (hot spots) of radioisotopes or fuel were detected along the vertical axis in either core. The ${ }^{137} \mathrm{Cs}$ concentration was relatively constant between Core 34 and Core 36 and the regions with high nickel concentrations correlated with the ${ }^{137} \mathrm{Cs}$ peaks in the gamma scans. These observations are consistent with the historical information regarding the ferrocyanide-scavenging process, the gamma activity pattern obtained from the scans, and the ICP element distribution through the subsegments. The other major source of radiological activity was ${ }^{90} \mathrm{Sr}$, which had a very skewed distribution between Core 34 and Core 36, probably arising from the later waste transfers into tank 241-C-112 after the ferrocyanide scavenging runs were completed. This is not a "hot spot" type phenomena, but an artifact of sampling near the waste inlet and outlet. There is no evidence of a self-concentration mechanism (Dickinson et al. 1993). Heat-load calculations are further evidence supporting the contention that the relatively high ${ }^{90} \mathrm{Sr}$ concentrations are believed to be a local phenomenon. The bulk waste temperature in the tank, obtained from two thermocouple trees, is $29^{\circ} \mathrm{C}\left(85^{\circ} \mathrm{F}\right)$. Comparisons of heat-load calculations, using the temperature profiles from the thermocouple trees and the higher ${ }^{90} \mathrm{Sr}$ concentrations, do not agree with the tank waste temperature measurements and other observations of the tank waste. The radiological activity of tank 241-C-112 waste material was relatively low (ranging from 0.15 to $2 \mathrm{R} / \mathrm{hr}$, measured through the drill string). No significant radiological activity was found in the drainable liquid in the tank or in the water or acid digestion of the samples. This suggests that ${ }^{90} \mathrm{Sr}$ and ${ }^{137} \mathrm{Cs}$ are quite insoluble.

Indications from Core 34 data show that material has physical and chemical properties corresponding to those expected for ferrocyanide waste. Water content, nickel concentration, and density values are consistent with the simulant values. Indications from Core 36 data show that material appears to have ferrocyanide waste overlying a bismuth phosphate first cycle decontamination and/or UR waste heel. However, no firm evidence of $\mathrm{BiPO}_{4}$ $1 C$ waste was ever found from the assays. The concentration of nickel, calcium, ${ }^{137} \mathrm{Cs}$, and uranium as a function of depth appears to confirm this observation. In addition, this behavior is consistent with historical information. However, in both cases DSC results from the suspected 
ferrocyanide waste in tank 241-C-112 indicate that the material is considerably less energetic than the corresponding waste simulant. Core 35 is indeterminate. It may be a combination of ferrocyanide waste and unscavenged UR waste. Results of aging studies now underway on flowsheet simulants may demonstrate that radiolytic, hydrolytic, and thermal processes in the tanks, over the last 35 years, have combined to dissolve, dilute, and destroy the reactive ferrocyanide compounds. The data from tank 241-C-112 strongly $\therefore$ idicate that the waste lacks the fuel concentration to sustain any $p_{1}$ spagating exothermic behavior, and a heat source intense enough to trigger a reaction is absent.

\subsection{ENERGETICS ANALYSIS}

Thermodynamic and kinetics (propagation) studies of simulants are bounding the reactivity of the ferrocyanide/oxidizer reactions. Results indicate that U Plant ferrocyanide wastes cannot create a propagating hazard; $T$ Plant waste is expected to behave similarly. Ferrocyanide simulants made by the In Farm flowsheet are more reactive. The waste in tank 241-C-112 and the other C Farm tanks, representing 20 to 25 percent of the ferrocyanide inventory added to the tanks, was made by a similar process and was a potential cause for concern. However, if the In Farm simulants contained at least 15 weight percent. water, that moisture content precluded an uncontrolled, propagating reaction (Fauske 1992).

Three core samples were obtained from tank 241-C-112, a tank considered to contain one of the highest concentrations of ferrocyanide. All three cores were broken down into smaller subsegments and examined for reactivity using DSC; none of the samples exhibited any propagating behavior. The samples had a moisture content ranging from 34 to 64 wt\% water and a $\Delta H$ ranging from $-0.02 \mathrm{~kJ} / \mathrm{g}$ of dry material to $-0.04 \mathrm{~kJ} / \mathrm{g}$ dry material $(4.4$ to $8.6 \mathrm{cal})$. The onset temperatures for the exotherms ranged between $275{ }^{\circ} \mathrm{C}$ and $290{ }^{\circ} \mathrm{C}--\mathrm{close}$ to that predicted by the simulants. The simulant may have represented the waste as it was initially precipitated in the tank; several of the physical and chemical properties of the simulants are quite close to those of the tank waste. However, further chemical analysis indicates that the waste material has a total cyanide content much lower than expected from the simulant formulations and, correspondingly, tank $241-C-112$ waste material is not as energetic as the analogous waste simulants. Tank $241-C-112$ sample material is nearly 30 times less chemically reactive than the comparable In Farm simulant material (tank 241-C-112 waste: $-0.04 \mathrm{~kJ} / \mathrm{g}$; In Farm

simulant: $-1.20 \mathrm{~kJ} / \mathrm{g}$ ). The causes of this behavior are hypothesized to be long-term exposure to radiation fields and high $\mathrm{pH}$ cladding waste. Both of these conditions are believed to degrade the ferrocyaride complexes. Further testing of simulant materials, as well as results from other ferrocyanide tanks, will aid in confirming this hypothesis. 
Calculations of the bulk waste inventory and inventories for several analytes of interest to the various safety issues (ferrocyanide, $\mathrm{NO}_{2}^{-}, \mathrm{NO}_{3}^{-}$, ${ }^{137} \mathrm{Cs},{ }^{90} \mathrm{Sr}$, plutonium, and water) were made. The calculated bulk inventory of ferrocyanide $(8,700 \mathrm{~g}$-mol) was far in excess of the 1,000 g-mol Ferrocyanide Watch List criteria, but the energetics results indicate that particular criteria do not account iun the dispersion of the ferrocyanide in the waste (i.e., the concentration may be too low to support a self-sustaining reaction). None of the other calculated bulk inventory values exceeded any level of concern (refer to Table 8-1).

Experimental and analytical evidence from tank $241-C-112$ suggests the risk from ferrocyanide compounds in Hanford Site high-level waste tanks is acceptable and that a propagating exothermic ferrocyanide reaction is incredible.

Table 8-1. Comparison of Tank 241-C-112 Analyte Values to Safety Issue Criteria.

\begin{tabular}{|l|l|l|}
\hline \multicolumn{1}{|c|}{ Analyte } & \multicolumn{1}{|c|}{ Safety Issue Criterial } & \multicolumn{1}{c|}{$\begin{array}{c}\text { Calculated/Measured } \\
\text { Value }\end{array}$} \\
\hline $\mathrm{Na}_{2} \mathrm{NiFe}(\mathrm{CN})_{6}$ & $1,000 \mathrm{~g}$-mol & $8,700 \mathrm{~g}$-mol \\
\hline$\Delta \mathrm{H}($ dry basis) & $-75 \mathrm{cal} / \mathrm{g}$ & $-9 \mathrm{cal} / \mathrm{g}$ \\
\hline $239 / 240 \mathrm{Pu}$ & $50 \mathrm{~kg}$ & $1.1 \mathrm{~kg}$ \\
\hline Temperature & $300^{\circ} \mathrm{F}\left(149^{\circ} \mathrm{C}\right)$ & $29^{\circ} \mathrm{C}\left(85^{\circ} \mathrm{F}\right)$ \\
\hline Heat Load & $11.72 \mathrm{kw}$ & $2.26 \mathrm{kw}$ \\
\hline $\begin{array}{l}\text { Organic } \\
\text { Content (TOC } \\
\text { Dry basis) }\end{array}$ & $\begin{array}{l}3.0 \mathrm{wt} \% \text { TOC } \\
\text { (10\% sodium acetate equivalent) }\end{array}$ & $0.75 \mathrm{wt} \%$ TOC \\
\hline
\end{tabular}

${ }^{1}$ (Lindsey 1986; RHO 1988; Boyles 1992; Reep 1992)

\subsection{RECOMMENDATIONS}

The following recommendations are made based on the data and analyses presented in this report and the goals of the characterization effort.

- Gamma scanning assay of segments should be discontinued for SSTs until an adequate core sample from tank 241-BY-104 is obtained.

- The Watch List criteria for the Ferrocyanide waste tank USQ should be expanded so that it includes concentration or energetics based measurements.

- Tank 241-C-112 should be removed from the Ferrocyanide Watch List. 
- A statistical comparison between the results from tank 241-C-109 (when available) and tank 241-C-112 should be performed to determine the degree of similarity between the tanks.

- An analysis for the formate anion should be done on the water soluble material to aid in confirming that the ferrocyanide has degraded.

- The DSC analysis should be performed under an inert atmosphere to better represent the waste conditions in the tank. 


\subsection{REFERENCES}

Abrams, R. B., 1956, History: Metal Recovery Waste Scavenging Program, HW-43066, General Electric Company, Richland, Washington.

Anderson, J. D., 1990, A History of the 200 Area Tank F:rms, WHC-MR-0132, Westinghouse Hanford Company, Richland, Washington.

Babad, H., B. C. Simpson, R. J. Cash, M. A. Lilga, 1993, The Role of Aging in Resolving the Ferrocyanide Safety Issue, WHC-EP-0599, Westinghouse Hanford Company, Richland, Washington.

Bechtold, D. B., 1992, "Analysis of In-Plant Ferrocyanide Solids," Internal Memo 12110-PC92-014, Westinghouse Hanford Company, Richland, Washington.

Bird, R. B, W. E. Stewart, E. N. Lightfont, 1960, Transport Phenomena, John Wi iey and Sons. New York, New York.

Borsheim, G. L. and B. C. Simpson, 1991, An Assessment of the Inventories of the Ferrocyanide Watchlist Tanks, WHC-SD-WM-ER-133 Rev. 0, Westinghouse Hanford Company, Richland, Washington.

Boyles, V. C., 1992, Operating Specifications for Single-Shell Waste Storage Tanks, OSD-T-151-00013 Rev D-1, Westinghouse Hanford Company, Richland, Washington.

Burger, L. L., 1984, Complexant Stability Investigation, Task 1, Ferrocyanide Solids, PNL-5441, Pacific Northwest Laboratories, Richland, Washington.

Burger, L. L., 1989, Complexant Stability Investigation, Task 1-Ferrocyaride solids, PNL-5441, Pacific Northwest Laboratory, hichland, Washington.

Burger, L. L., and R. D. Scheele, 1990, The Reactivity of $\mathrm{Cs}_{2} \mathrm{NiFe}(\mathrm{CN})_{6}$ Towards Nitrate and Nitrite Salts, PNL-7550, Pacific Northwest Laboratory, Richland, Washington.

Cash, R. J., 1993, Ferrocyanide Safety Program - Removal of Six Tanks from Ferrocyanide Tank List, (letter 9259120 to J. H. Anttonen, January 14, 1993), Westinghouse Hanford Company, Richland, Washington.

Colby, S. A., and M. D. Crippen, 1991, Graphical Presentation of Ferrocyanide Tank Compositions, WHC-SA-1304-FP, Westinghouse Hanford Company, Richland, Washington.

Dickinson, D. R., J. M. McLaren, G. L. Borsheim, M. D. Crippen, Ferrocyanide Safety Program: Credibility of Drying Out Ferrocyanide Tank Waste Sludge by Hot Spots, WHC-EP-0648, Rev. 0, Westinghouse Hanford Company, Richland, Washington.

DOE, 1987, Final Environmental Impact Statement, Disposal of Hanford Defense High-Level Transuranic Wastes, Hanford Site, Richland, Washington, DOE/EIS-0113, Vol. 1 through 5, U.S. Department of Energy, Washington, D.C. 
Ecology, EPA, and DOE, 1992, Hanford Federal Facility Agreement and Consent Order, 2 vols., Washington State Department of Ecology, U.S. Environmental Protection Agency, U.S. Department of Energy, 01ympia, Washington.

Fauske, H. K., 1992, Adiabatic Calorimetry and Reaction Propagation Rate Tests with Synthetic Ferrocyanide Materials Including U Plant-1, U Plant-2, In Farm 1, In Farm 2 and Vendor-Procured Sodium Nickel Ferrocyanide, Fauske \& Associates, Inc., Burr Ridge, Illinois.

General Electric, 1958, Record of Scavenged TBP Waste, General Electric Company, Richland, Washington.

Hanion, B. M., 1992, Tank Farm Surveillance and Waste Status Summary Report for September 1992, WHC-EP-0182-39, Westinghouse Hanford Company, Richland, Washington.

HASM, 1993, Single-Shell Tank Characterization Project and Safet:" Analysis Project Core 34, 35 and 36, Validation Report Tank 241-C-112, WHC-SD-WM-DP-026, Westinghouse Hanford Company, Richland, Washirigton.

Hill, J. G., W. I. Winters, B. C. Simpson, J. W. Buck, P. J. Chamberlain, and V. L. Hunter 1991, Waste Characterization Plan for the Hanford Site Single-Shell Tanks--Appendix I: Test Plan for Sampling and Analys is of Ten Single-Shell Tanks, WHC-EP-0210 Rev. 3, Westinghouse Hanford Company, Richland, Washington.

Hill, J. G., 1991, Modified Test Plan for the Ferrocyanide Single-Shell Tanks, 241-C-112, C-109 and T-107, Correspondence No. 915211, Westinghouse Hanford Company, Richland, Washington.

Jensen, L. and B. J. Whitcher, 1992, "Statistical Analysis of Tank 241-U-110 Data, IV: Concentration Estimates," Internal Memo 12100--PLT92-068, Westinghouse Hanford Company, Richland, Washington.

Jeppson, D. W. and J. J. Wong, 1993, Ferrocyanide Waste Simulant Characterization, WHC-EP-0631, Westinghouse Hanford Company, Richland, Washington.

Jungfleisch, F. M., 1984, TRAC: A Preliminary Estimation of the Waste Inventories in Hanford Tanks Through 1980, SD-WM-TI-057, Rockwell Hanford Operations, Richland, Washington.

Lilga, M. A., M. R. Lumetta, W. F. Riemath, R. A. Romine, and G. F. Schiefelbein, 1992, "Ferrocyanide Safety Project, Subtask 3.4, Aging Studies FY 1992, Annual Report," PNL-8387 UC-721, Pacific Northwest Laboratory, Richland, Washington.

Lindsey, D. W., 1986, Operating Specifications for Single-Shell Waste Storage Tanks, OSD-T-151-00013, Rockwell Hanford Operations, Richland, Washington. 
National Defense Authorization Act for Fiscal Year 1991, Public Law 101-510, Section 3137, "Safety Measures for Waste Tanks at Hanford Nuclear Reservation," November 5, 1990.

Peach, J. D., 1990, "Consequences of Explosion of Hanford's Single-Shell Tanks Are Understated," (Letter B-241479 to C. M. Synar, Chairman of Environment, Energy and Natural Resources Subcommittee, Committee on Government Operations, House of Representatives), GAO/RCED-91-34, General Accounting Office, Washington, D.C.

Peterson, L. R., H. Babad, S. A. Bryan, A. J. Schmidt, 1993, Autogeneous Hydrothermal Oxidation in Simulated Hanford Double-She 11 Tank Wastes, PNL-SA-22181, Pacific Northwest Laboratory, Richland, Washington.

Reep, I. E., 1992, Status Report on Resolution of Waste Tank Safety Issues at the Hanford Site, WHC-EP-0600, Westinghouse Hanford Company, Richland, Washington.

RHO, 1988, Criticality Prevention Specifications for Waste Storage Tanks and Associated Equipment, CPS-T-149-00010, Rockwell Hanford Operations, Richland, Washington.

Scheele, R. D., L. L. Burger, J. M. Tingey, S. A. Bryan, G. L. Borsheim, B. C. Simpson, R. J. Cash, and H. H. Cady, 1991, "Ferrocyanide-Containing Waste Tanks: Ferrocyanide Chemistry and Reactivity," in the Proceedings of Environmental Restoration 91, University of Arizona, Tucson, Arizona.

Schmidt, W. C., and M. J. Stedwe11, 1954, Production Test 221-T-18 Scavenging of First Cycle Waste, HW-33252, General Electric Company, Richland. Washington.

Sloat, R. J., 1954, TBP Plant Nickel Ferrocyanide Scavenging Flowsheet, HW-30399, General Electric Company, Richland, Washington.

Sloat, R. J., 1955, In Farm scavenging Operating Procedure and Control Data, HW-38955 Rev. 1, General Electric Company, Richland, Washington.

Snedecor, G. W., and W. G. Cochran, 1980, Statistical Methods, Seventh Edition, Iowa State University Press, Ames, Iowa.

Tingey, J. M., J. D. Matheson, S. G. McKinley, T. E. Jones, and K. H. Pool, 1993, Characterization of Hanford Tank Wastes Containing Ferrocyanides, PNL-SA-21497, Pacific Nort.hwest Laboratory, Richland, Washington.

Weast, R., 1984, Handbook of Chemistry and Physics, 64th Ed., CRC Press, Boca Raton, Florida.

Winters, W. I., L. Jensen, L. M. Sasaki, R. L. Weiss, J. F. Keller, A. J. Schmidt, and M. G. Woodruff 1990a, Waste Characterization Plan for the Hanford Site Single-Shell Tanks, WHC-EP-0210 Rev. 1, Westinghouse Hanford Company, Richland, Washington. 
Winters, W. I., L. Jensen, L. M. Sasaki, R. L. Weiss, J. F. Keller, A. J. Schmidt, and M. G. Woodruff 1990b, Waste Characterization Plan for the Hanford Site Single-Shell Tanks, WHC-EP-0210 Rev. 2, Westinghouse Hanford Company, Richland, Washington. 
WHC-EP-0640

APPENDIX A

CALCULATIONS

APP $A-i$ 
WHC-EP-0640

This page intentionally left blank.

APP $A-i i$ 


\section{APPENDIX A}

\section{CALCULATIONS}

\section{Theoretical Energetic Behavior of C-112 Waste:}

Assume 1.0 and 1.5 vol\% precipitate formation; use waste volumes generated from Borsheim-Simpson spreadsheet model.

Ferrocyanide waste volume: 1.0 vol\% $=31,000$ gallons

C 1.5 vol\% $=42,600$ gallons

Input mole of ferrocyanide: $\quad 78,445 \mathrm{~g}-\mathrm{mol} \mathrm{Na}_{2} \mathrm{NiFe}(\mathrm{CN})_{6}$

Calculated moles

ferrocyanide remaining: $\quad 1.0$ vol\% $=65,900 \mathrm{~g}-\mathrm{mol}_{\mathrm{Na}} \mathrm{NiFe}(\mathrm{CN})_{6}$

1.0 vol\% $=65,900 \mathrm{~g}-\mathrm{mol} \mathrm{Na}_{2} \mathrm{NiFe}(\mathrm{CN})_{6}$
1.5 vol\% $=60,400 \mathrm{~g}-\mathrm{mol} \quad \mathrm{Na}_{2} \mathrm{NiFe}(\mathrm{CN})_{6}$

Analytical estimate

derived from $\mathrm{Ni}$ content

72,100 g-mol $\mathrm{Na}_{2} \mathrm{NiFe}(\mathrm{CN})_{6}$

(discounting $\mathrm{Ni}$ from ${ }^{60} \mathrm{Co}$ scavenging)

Bulk Mass of Ferrocyanide waste (Density $=1.50 \mathrm{~g} / \mathrm{mL}$ ):

$(31,000 \mathrm{gal}) *(3785 \mathrm{~mL} / \mathrm{gal}) *(1.50 \mathrm{~g} / \mathrm{miL})=1.76 \mathrm{E}+08 \mathrm{~g}$ waste

$(42,600 \mathrm{gal}) *(3785 \mathrm{~mL} / \mathrm{gal}) *(1.50 \mathrm{~g} / \mathrm{mL})=2.42 \mathrm{E}+08 \mathrm{~g}$ waste

Mass of Ferrocyanide in Ferrocyanide waste:

(e) 1.0 vol\% $=(65,900 \mathrm{~g}-\mathrm{mol}) *(316.7 \mathrm{~g} / \mathrm{g}-\mathrm{mol})=2.09 \mathrm{E}+07 \mathrm{~g} \mathrm{Na}_{2} \mathrm{NiFe}(\mathrm{CN})_{6}$

C 1.5 vol\% $=(60,400 \mathrm{~g}-\mathrm{mol}) *(316.7 \mathrm{~g} / \mathrm{g}-\mathrm{mol})=1.91 \mathrm{E}+07 \mathrm{~g} \mathrm{Na}_{2}^{2} \mathrm{NiFe}(\mathrm{CN})_{6}^{6}$

Weight Percent Ferrocyanide in waste (range):

(c) 1.0 v01\%: $\frac{2.09 \mathrm{E}+07 \mathrm{~g} \mathrm{Na}}{1.76 \mathrm{E}+08 \mathrm{~g} \text { waste }} \frac{\mathrm{NiFN})_{6}}{}{ }^{*}(100)=11.88$ wt $\%$

c 1.5 v01\%: $\frac{1.91 \mathrm{E}+07 \mathrm{~g} \mathrm{Na}}{2.42 \mathrm{E}+08 \mathrm{~g} \mathrm{waste}} \frac{\mathrm{NiFe}(\mathrm{CN})_{6}}{*}(100)=7.89 \mathrm{wt} \%$

Assume $51 \%$ average water content, $49 \%$ solids

(In Farm-1 simulants; Jeppson and Wong 1993)

Weight Percent Ferrocyanide (Dry basis)

c 1.0 vol\%: $\frac{2.09 E+07 \mathrm{a} \mathrm{Na}}{1.76 \mathrm{E}+08 \mathrm{~g} \text { waste }(0.49)} \frac{\mathrm{NiFe}(\mathrm{CN})_{6}}{*}(100)=24.24$ wt\%

(c) 1.5 vol\%: $\quad \frac{1.91 E+07 \mathrm{~g} \mathrm{Na}_{2}}{2.4 i F e}(\mathrm{CN})_{6} *(100)=16.10 \mathrm{wt} \%$ $2.42 E+08 \mathrm{~g}$ waste $(0.49)$ 
Table A-1. Energetic Properties of Waste Simulants (Fauske 1992).

\begin{tabular}{|c|c|c|c|}
\hline Simulant & $\begin{array}{c}\text { Ferrocyanide Content } \\
\text { (Dry basis) }\end{array}$ & $\begin{array}{c}\Delta \mathrm{H}_{\text {simulant }} \\
(\mathrm{kJ} / \mathrm{g} \text { dry simulant) }\end{array}$ & $\begin{array}{c}\Delta \mathrm{H}_{\text {ferrocyanide }} \\
\left(\mathrm{kJ} / \mathrm{ga}_{2} \text { Nife(CN) }_{6}\right)\end{array}$ \\
\hline U Plant-1 & $4.3 \mathrm{wt} \%$ & -0.17 & -3.95 \\
\hline U Plant-2 & $8.6 \mathrm{wt} \%$ & -0.34 & -3.95 \\
\hline In Farm-1 & 25.5 wt\% & -1.20 & -4.71 \\
\hline
\end{tabular}

A direct, linear relationship can be assumed between the ferrocyanide (or cyanide) content of the waste and the energy content of the material.

$\left.\Delta \mathrm{H}_{\text {sample }}=\left(\mathrm{Wt} \% \mathrm{Na}_{2} \mathrm{NiFe}(\mathrm{CN})_{6}\right) *\left(-3.95 \mathrm{KJ} / \mathrm{g} \mathrm{Na} \mathrm{NiFe}_{2} \mathrm{CN}\right)_{6}\right)$

Therefore, the theoretical energetic behavior of the waste as it was initially stored in tank 241-C-112 is between:

$(16.1 \%) *(-3.95)=-0.64 \mathrm{KJ} / \mathrm{g}$ waste; or $152 \mathrm{cal} / \mathrm{g}$ waste

$(24.24 \%) *(-3.95)=-0.96 \mathrm{KJ} / \mathrm{g}$ waste; or $229 \mathrm{cal} / \mathrm{g}$ waste

The basis for the exothermic potential of the reaction is $-3.95 \mathrm{~kJ} / \mathrm{g}$ $\mathrm{Na}_{2} \mathrm{NiFe}(\mathrm{CN})_{6}$. This value is used for several reasons. The measurement of the two $U$ Plant simulants was performed on much larger samples, thus is not as sensitive to rounding and experimental error. In addition, the measured gaseous products from the U Plant reaction were 0.075 moles produced out of a theoretical 0.11 moles; this represents a release fraction of $68.2 \%$, suggesting incomplete or less efficient combustion. There are several alternative reaction paths, however, the most reactive thermodynamic pathway has a $\Delta \mathrm{H}$ of $-9.6 \mathrm{KJ} / \mathrm{g} \mathrm{Na} \mathrm{NiFe} \mathrm{CN})_{6}$. Therefore a reaction efficiency for this waste matrix is $(-3.95 /-9.6) * 100=41.1 \%$. It can be assumed that the release fraction and reaction efficiency in the waste matrix would not be any greater than that exhibited by the simulants. However, greater heats of reaction can be expected from mixtures with higher fuel contents, as long as there is sufficient oxidizer. This behavior is expected because factors contributing to combustion efficiency are more favorable: (1) a higher fuel/oxidant interface and (2) fewer solid diluents. This may be why the In Farm-1 simulant exhibits a higher heat of reaction than the $U$ Plant simulants.

Determination of ${ }^{137} \mathrm{Cs}$ values from Revised Borsheim/Simpson Model:

The approximate amount of ${ }^{137} \mathrm{Cs}$ processed through $241-C_{-11} 12$ during the scavenging campaign was $748,000 \mathrm{Ci}$. The half-life of ${ }^{137} \mathrm{Cs}$ is 30.17 years. The decay period for the waste is assumed to be 35 years (1958-1993). The decay factor for this timespan is thus:

$e^{-(\ln 2 / 30.17) * 35}=0.4475$

Therefore, the ${ }^{137} \mathrm{Cs}$ remaining from the scavenging campaign is $(748,000 \mathrm{Ci}) *(0.4475)=334,700 \mathrm{Ci}$ 
The amount of ${ }^{137} \mathrm{Cs}$ captured in the tank is assumed to be directly proportional to the amount of ferrocyanide waste solids retained.

Gallons of ferrocyanide solids produced:

C 1.0 vol\% $=46,200$ gallons

C 1.5 vol\% $=69,300$ gallons

Calculated volume

ferrrocyanide waste retained:

e 1.0 vol\% $=31,000$ gallons

C 1.5 vol\% $=42,600$ gallons

Calculated transfer losses:

C 1.0 vol\% $=15,200$ gallons $12,600 \mathrm{~g}-\mathrm{mol}^{2} \mathrm{Na}_{2} \mathrm{NiFe}(\mathrm{CN})_{6}$ to $B C-18$ and $/$ or $B Y-108$

C 1.5 vol\% $=26,700$ gallons $18,000 \mathrm{~g}-\mathrm{mol}_{\mathrm{Na}} \mathrm{NiFe}(\mathrm{CN})_{6}$ to $\mathrm{BC}-10, \mathrm{BC}-18$, and $/$ or $\mathrm{BY}-108$

${ }^{137} \mathrm{Cs}$ retained in $241-\mathrm{C}-112$ :

(c) 1.0 v0l\% $=\frac{31,000 \text { gallons }}{46,200 \text { gallons }}(334,700 \mathrm{Ci})=224,600 \mathrm{Ci}$

(c) 1.5 vol\% $=\frac{42,600 \text { gallons }}{69,300 \text { gallons }}(334,700 \mathrm{Ci})=205,700 \mathrm{Ci}$

Comparison of Actual Waste Values with Theoretical Estimates

Total cyanide values can provide estimates of ferrocyanide content; and this derived ferrocyanide content can be used to determine the energy content of the sample (assuming all cyanide detected is present as ferrocyanide).

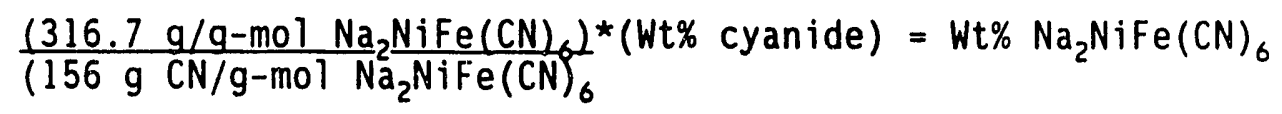

and using the derived ferrocyanide value in the previously described energetic relationship:

$\Delta \mathrm{H}_{\text {sample }}=\left(\mathrm{Wt} \% \mathrm{Na}_{2} \mathrm{NiFe}(\mathrm{CN})_{6}\right) *\left(-3.95 \mathrm{KJ} / \mathrm{g} \mathrm{Na} 2 \mathrm{NiFe}(\mathrm{CN})_{6}\right)$

Conversely, the energy content of the waste is a reasonable indicator of the ferrocyanide content in the waste. By rearranging Equation (1)

$$
\begin{aligned}
& \frac{\Delta \mathrm{H}_{\text {sample }}}{-3.95 \mathrm{KJ} / \mathrm{g}} \\
& \left.\mathrm{Na} \mathrm{NiFe}_{2} \mathrm{CN}\right)_{6}
\end{aligned}=W t \% \mathrm{Na}_{2} \mathrm{NiFe}(\mathrm{CN})_{6}
$$


However, because of the semi-quantitative nature of the DSC assay, values obtained in this manner are likely no better than qualitative results $( \pm 100 \%)$ for low fuel concentrations/small exotherms. For samples with high fuel contents (and consequently, exhibiting strong exotherms), the values are considered much more accurate.

Calculation of Bulk Inventories for Analytes of Importance

From the distribution of the solids and liquids in the samples, the measurements from tank farm surveillance, and the analyte profiles from the quarter-segments, a representation of the overall tank profile can be visualized (Figure A-1). These observations from the tank suggest that there are 5 distinct regions in the tank, each possessing a specific volume and characteristic compositions. These regions are:

- Dished Bottom: First Cycle $\mathrm{BiPO}_{4}$ waste or Unscavenged Uranium Recovery (UR) waste

- Tank Layer 1: Unscavenged Uranium Recovery (UR) waste

- Tank Layer 2: Unscavenged UR waste and Ferrocyanide Scavenging Waste

- Tank Layer 3: Ferrocyanide Scavenging Waste

- Supernatant

The volumes for each region were derived as follows:

- Dished Bottom: 15,000 gallons $(57,700 \mathrm{~L})$

The volume of the dish is accepted as 12,500 gallons; in addition it is believed that an additional inch of the same waste $(2,750$ gallons) rests on top of the material in the dish. This gives a volume of approximately 15,000 gallons.

- Tank Layer 1: 9,800 gallons $(37,100 \mathrm{~L})$

Calculate a volume using a slab 1.5 subsegments high on one side and 0 subsegments high on the other. (2,750 gallons/inch $) *(4.75 \mathrm{in.} /$ subsegment $) *[0.5 *(1.5+0$ subsegments $)]=9,800$ gallons .

- Tank Layer 2: 9,800 gallons $(37,100 \mathrm{~L})$

Same as Tank Layer 1

- Tank Layer 3: 41,800 gallons $(158,000 \mathrm{~L})$

Calculate a volume using a slab 2.5 subsegments high on the core 36 side and 3.9 subsegments high on the Core 34 side. (2,750 gallons/inch)*[( 4.75 in. $)$ subsegment $) *(2.5$ subsegments $)+(0.5) *(4.75) *(1.4$ subsegments $)]=$ 41,800 gallons. 
Figure A-1. Waste Profile of Tank 24!-C-112.

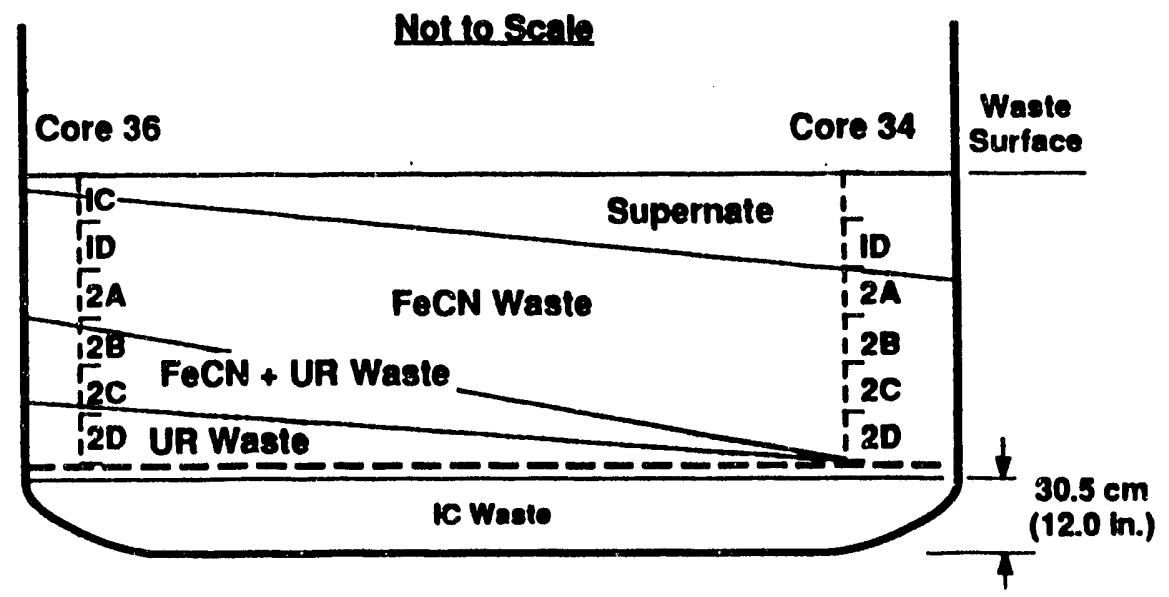

29304019.7

- Dished Bottom: First Cycle $\mathrm{BiPO}_{4}$ waste or Unscavenged Uranium Recovery (UR) waste

- Tank Layer 1: Unscavenged Uranium Recovery (UR) waste

- Tank Layer 2: Unscavenged UR waste and Ferrocyanide Scavenging Waste

- Tank Layer 3: Ferrocyanide Scavenging Waste

- Supernatant 
Total Solids Volume $=76,400$ gallons $(289,000 \mathrm{~L})$

- Supernatant: 36,300 gallons $(137,000 \mathrm{~L})$

Calculate a volume using a slab 6.4 inches high $(45.3-38.9)$ on the core 36 side and 13.6 inches high $(45.3-31.7)$ on the Core 34 side. $(2,750$ gallons $/$ inch $) *(6.4$ in. $)+(0.5) *(2,750$ gallons $) *(13.6$ in. $)=$ 36,300 gallons.

Total Waste Volume: $\quad 112,700$ gallons

Check calculated volume with tank surveillance records: 104,000 gallons

Percent Difference $=112.700-104.000 * 100=+8.4 \%$ 104,000

Using these volumes and a bulk density of $1.50 \mathrm{~g} / \mathrm{mL}$ for the solids and $1.27 \mathrm{~g} / \mathrm{mL}$ for the supernatant, masses for the various regions can be calculated. Also, representative concentrations for the various analytes from each of the regions can be developed.

Table A-2: Basis for Bulk Inventory Calculations.

\begin{tabular}{|l|c|c|l|}
\hline Tank Region & $\begin{array}{c}\text { Volume } \\
\text { (gallons) }\end{array}$ & $\begin{array}{c}\text { Mass } \\
(\mathrm{Mg})\end{array}$ & $\begin{array}{c}\text { Concentration Values Used } \\
\text { for Inventory Est imate }\end{array}$ \\
\hline Dished Bottom & 15,000 & 85.2 & Core 36-2D \\
\hline Tank Layer 1 & 9,800 & 55.6 & Avg. Core 36-2C and 36-2D \\
\hline Tank Layer 2 & 9,800 & 55.6 & Core 36-2B \\
\hline Tank Layer 3 & 41,800 & 237.3 & $\begin{array}{l}\text { Avg. Core 36-2A, 36-1D, } \\
36-1 C \text { and Core 34-2D, 34-2C, } \\
34-2 B\end{array}$ \\
\hline Supernatant & 36,300 & 174.5 & $\begin{array}{l}\text { Avg. Core 34 and Core 35 } \\
\text { Drainable liquid }\end{array}$ \\
\hline Total & 112,700 & 608.2 & \\
\hline
\end{tabular}

Tables $A-3, A-5$, and $A-7$ show the concentration values used to calculate the inventories. Tables $A-4, A-6$, and $A-8$ show the calculated bulk inventories for selected analytes. 
Table A-3. Bulk Inventory Basis for Energetics Analytes.

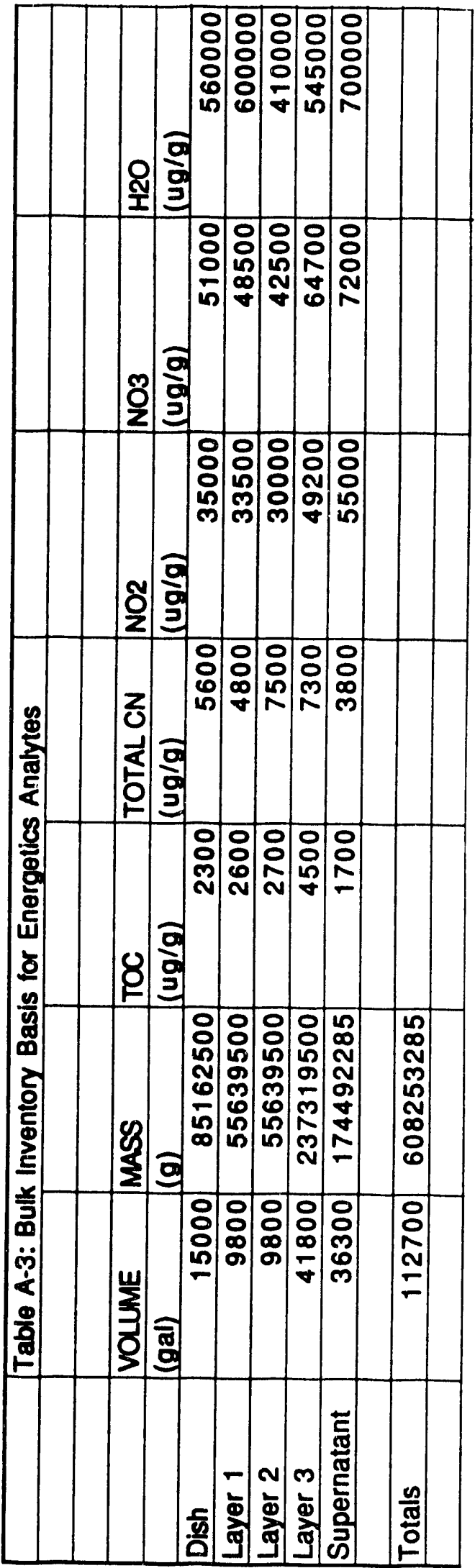


Table A-4. Calculated Inventories for Energetic Analytes.

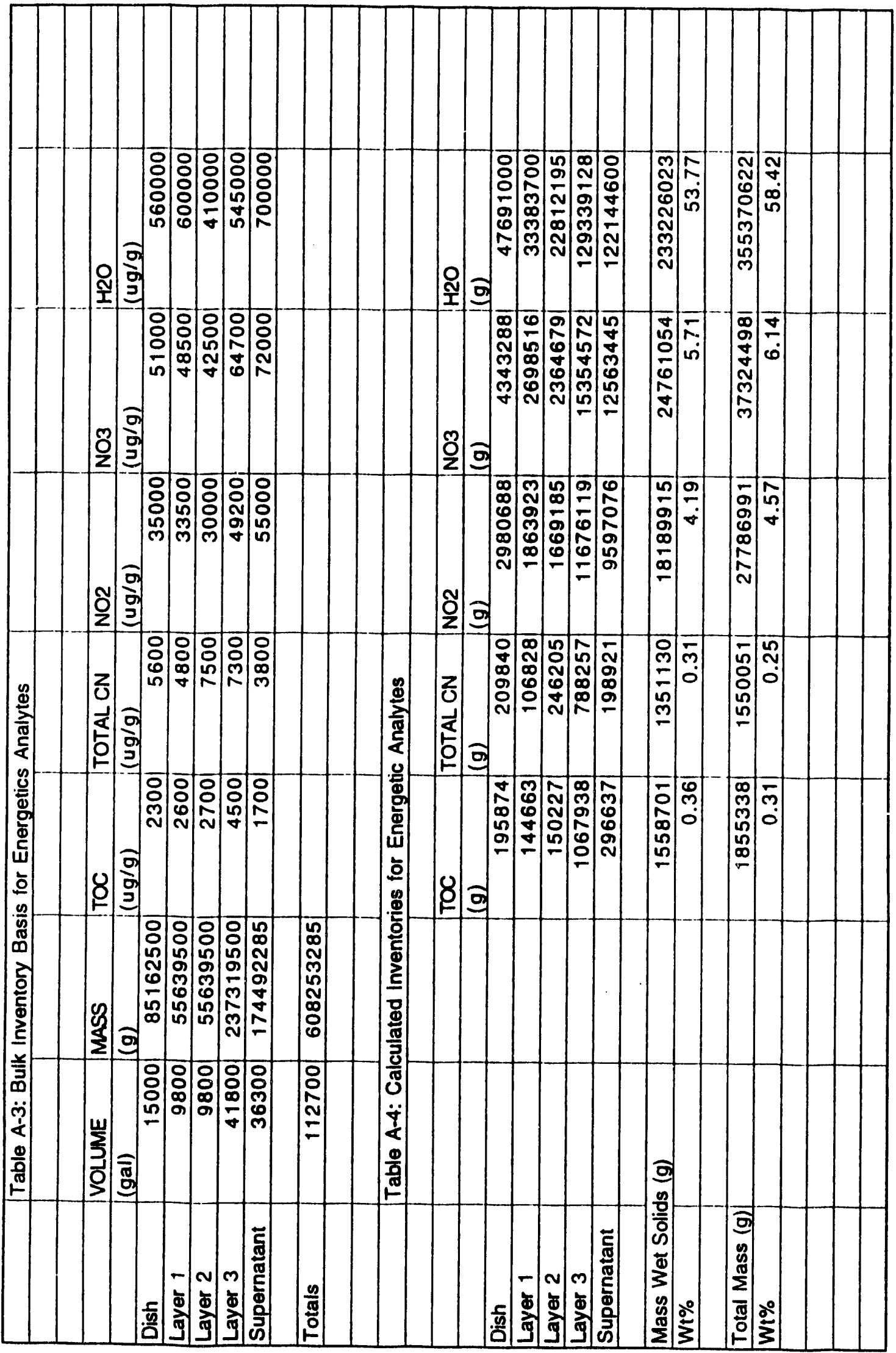


WHC-EP-0640

Table A-5. Bulk Inventory Basis for Cesium-137 and Strontium-90.

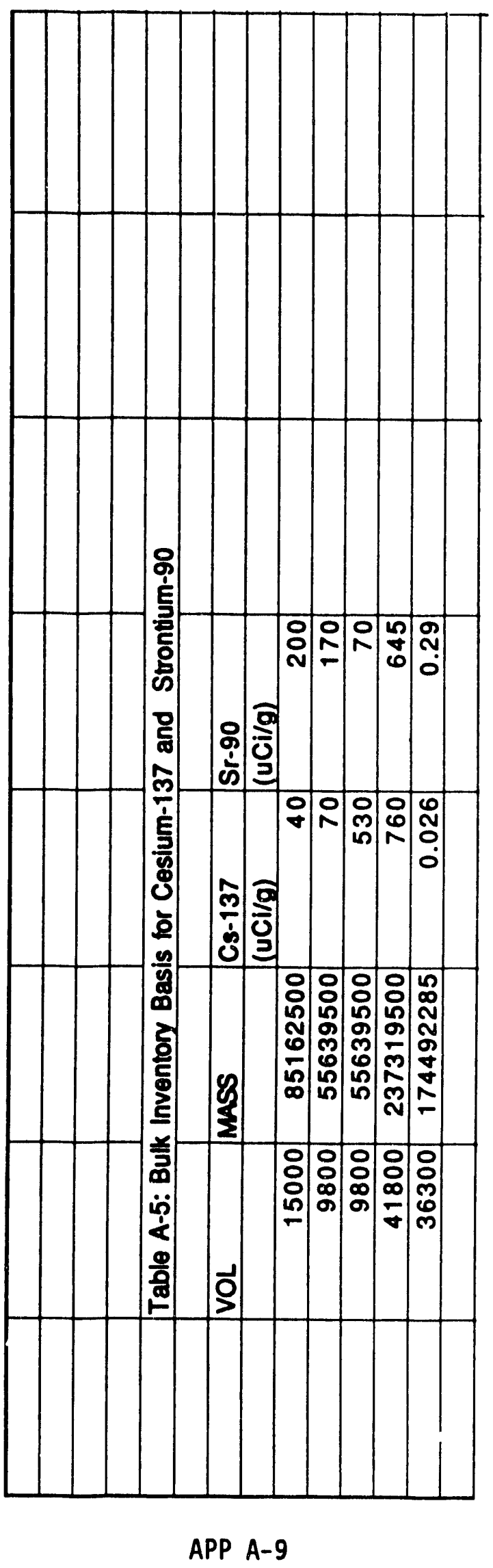


WHC-EP-0640

Table A-6. Calculated Inventories for Cesium-137 and Strontium-90.

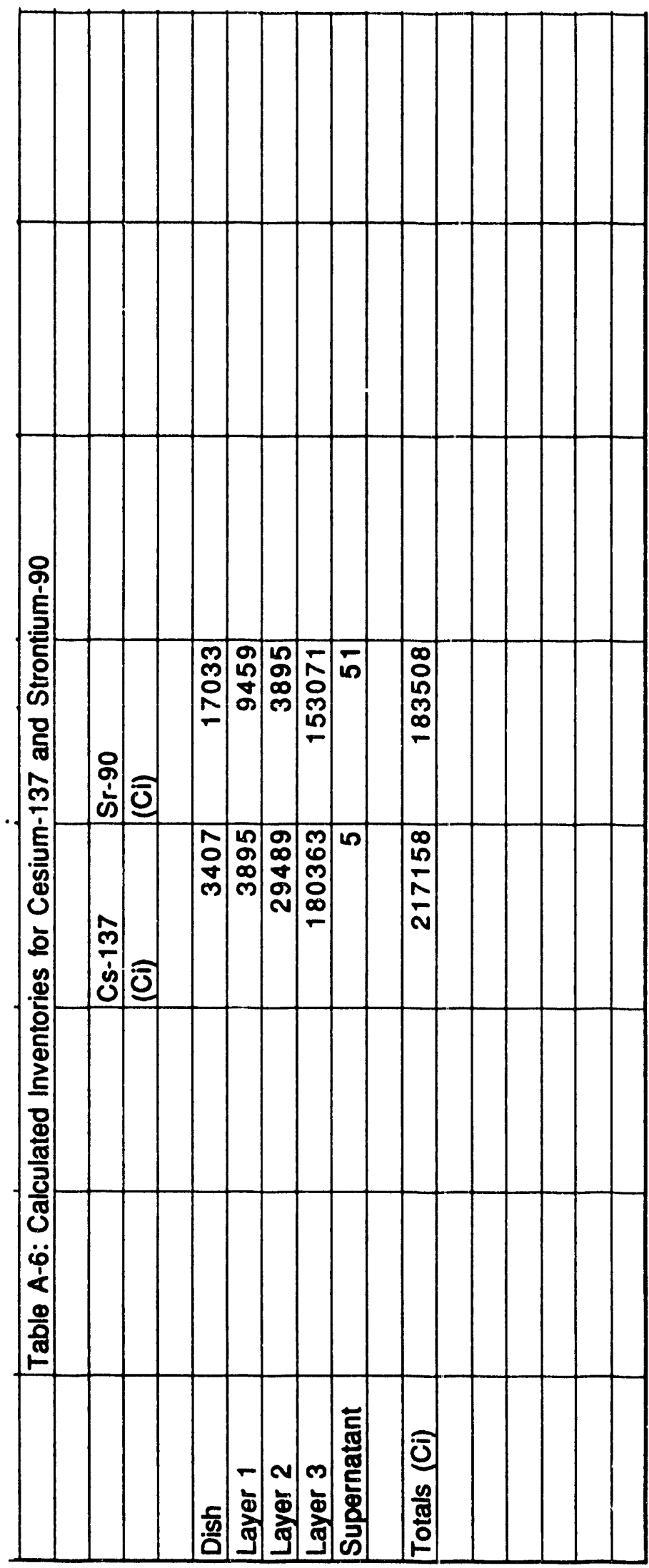

APP $A-10$ 
Table A-7. Bulk Inventory Basis for ICP Cations (wet solids).

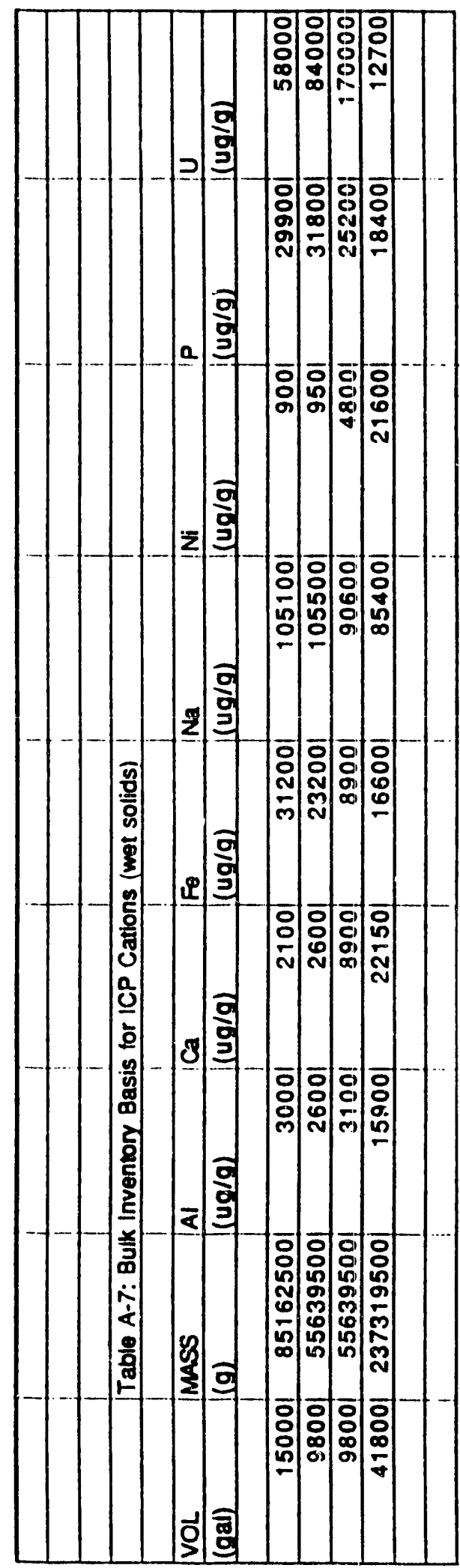


Table A-8. Calculated Inventory for ICP Cations (wet solids).

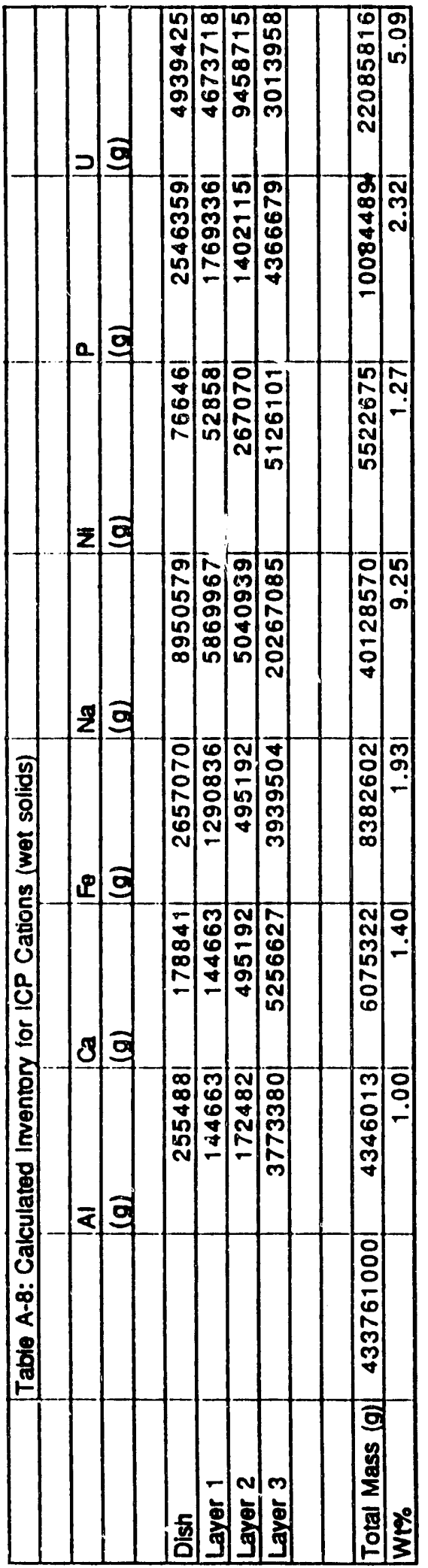


Compare ICP water leach phosphorous value with IC phosphate value.

Formula weights:

$\mathrm{P}: 31 ; \mathrm{PO}_{4}: 95$

Multiplier to

convert $\mathrm{P}$ to $\mathrm{PO}_{4}$ :

$95 \mathrm{~g} \mathrm{PO}_{4} / \mathrm{g}-\mathrm{mol}_{3}=3.1$

$31 \mathrm{~g} \mathrm{P} / \mathrm{g}-\mathrm{mol}$

Table A-9: Comparison of Water Leach ICP Phosphorous Value with IC Phosphate Value.

\begin{tabular}{|c|c|c|c|c|}
\hline Sample & $\begin{array}{c}\text { Water Leach P } \\
\text { ICP value } \\
(\mu \mathrm{g} / \mathrm{g})\end{array}$ & $\begin{array}{c}\text { Converted } \mathrm{PO}_{4} \text { value } \\
\text { derived from ICP } \\
(\mu \mathrm{g} / \mathrm{g})\end{array}$ & $\begin{array}{c}\text { IC } \mathrm{PO}_{4} \text { Value } \\
(\mu \mathrm{g} / \mathrm{g})\end{array}$ & $\begin{array}{c}\text { Percent } \\
\text { Difference }\end{array}$ \\
\hline Core 34 & 6380 & 19600 & 19100 & 2.6 \\
\hline Core 35 & 5630 & 17300 & 17800 & -2.8 \\
\hline Core 36 & 16500 & 50600 & 49500 & 2.2 \\
\hline
\end{tabular}

Since phosphates were used extensively in waste processing, assume all insoluble $P$ is present as $\mathrm{PO}_{4}$; subtract fusion ICP $P$ value and add corrected amount to $\mathrm{PO}_{4}$.

To correct mass balance for unanalyzed hydroxide content, multiply analyte concentration by multiplier.

Other multipliers:

Aluminum; assume aluminum is present predominantly as $\mathrm{Al}(\mathrm{OH})_{3}$.

Formula weights: $\quad \mathrm{Al}: 27 ; \mathrm{Al}(\mathrm{OH})_{3}: 78$

Multiplier to

convert $\mathrm{Al}$ to $\mathrm{Al}(\mathrm{OH})_{3}: \frac{78 \mathrm{~g} \mathrm{Al}(\mathrm{OH})_{3} / \mathrm{g}-\mathrm{mol}}{27 \mathrm{~g} \mathrm{Al} / \mathrm{g}-\mathrm{mol}}=2.9$

Iron; assume iron is present predominantly as $\mathrm{Fe}(\mathrm{OH})_{2}$.

Formula weights: $\quad \mathrm{Fe}: 56 ; \mathrm{Fe}(\mathrm{OH})_{2}: 90$

Multiplier to

convert $\mathrm{Fe}$ to $\mathrm{Fe}(\mathrm{OH})_{2}: \frac{90 \mathrm{~g} \mathrm{Fe}(\mathrm{OH})_{2} / \mathrm{g}-\mathrm{mol}}{56 \mathrm{~g} \mathrm{Fe} / \mathrm{g}-\mathrm{mol}}=1.6$

Nickel; assume nickel is present predominantly as $\mathrm{Ni}(\mathrm{OH})_{2}$.

Formula weights: $\quad \mathrm{Ni}: 58 ; \mathrm{Ni}(\mathrm{OH})_{2}: 92$ 
Multiplier to

convert $\mathrm{Ni}$ to $\mathrm{Ni}(\mathrm{OH})_{2}: \frac{92 \mathrm{~g} \mathrm{Ni}(\mathrm{OH})_{2} / \mathrm{g}-\mathrm{mol}}{58 \mathrm{~g} \mathrm{Ni} / \mathrm{g}-\mathrm{mol}}=1.6$

Uranium; assume uranium is present predominantly as $\mathrm{UO}_{2}(\mathrm{OH})_{2}$.

Formula weights: $\quad \mathrm{U}: 238 ; \mathrm{UO}_{2}(\mathrm{OH})_{2}: 304$

Multiplier to

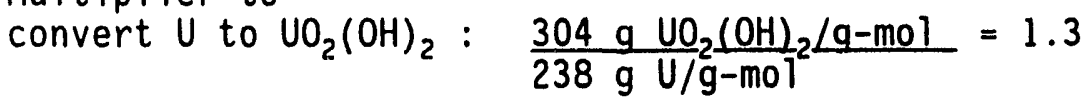

Total Carbon; assume carbon is present in three forms, and that the TOC and TIC assays did not consume or measure any cyanide:

$\begin{array}{ll}\text { Organic carbon (as acetate): } & \mathrm{C}_{2} \mathrm{H}_{3} \mathrm{O}_{2} \\ \text { Inorganic carbon (as carbonate): } & \mathrm{CO}_{3}\end{array}$

Ferrocyanide carbon (as cyanide): $\mathrm{CN}^{3}$

Formula weights: $\quad \mathrm{C}: 12 ; \mathrm{CN}: 26 ; \mathrm{C}_{2} \mathrm{H}_{3} \mathrm{O}_{2}: 59 ; \mathrm{CO}_{3}: 60$

Multiplier to

convert TOC to acetate:

$\frac{59 \mathrm{~g} \mathrm{C}}{24} \underline{\mathrm{H}}_{3} \underline{\mathrm{O}}_{2} \angle \mathrm{g}-\mathrm{mol}=2.45$

$24 \mathrm{~g} \mathrm{C} / \mathrm{g}-\mathrm{mol}$

Multiplier to convert

TIC to carbonate:

$\frac{60 \mathrm{~g} \mathrm{CO}_{3} / \mathrm{g}-\mathrm{mol}}{12 \mathrm{gC} / \mathrm{g}-\mathrm{mol}}=5$

Multiplier to

convert $\mathrm{C}$ to $\mathrm{CN}$ :

$\frac{26 \mathrm{~g} \mathrm{CN} / \mathrm{g}-\mathrm{mol}}{12 \mathrm{~g} \mathrm{C} / \mathrm{g}-\mathrm{mol}}=2.2$

$12 \mathrm{~g} \mathrm{C} / \mathrm{g}-\mathrm{mol}$ 
WHC-EP-0640

Table A-10: Energetic Calculations.

\begin{tabular}{|c|c|c|c|c|}
\hline Sample & $\begin{array}{c}\text { Measured Heat } \\
\text { of React ion } \\
(\mathrm{J} / \text { wet } \mathrm{g})\end{array}$ & $\begin{array}{l}\text { Wt Fraction } \\
\text { Solid }\end{array}$ & $\begin{array}{c}\text { Measured Heat } \\
\text { of React ion } \\
(\mathrm{J} / \text { dry g) }\end{array}$ & $\begin{array}{l}\text { Measured Heat } \\
\text { of Reaction } \\
\text { (cal/dry g) }\end{array}$ \\
\hline $34-10$ & -17 & 0.8 & -21.25 & -5.08 \\
\hline $34-2 B$ & -12 & 0.43 & -27.91 & -6.68 \\
\hline $34-2 C$ & -13 & 0.51 & -25.49 & -6.10 \\
\hline $34-2 D$ & -17 & 0.61 & -27.87 & -6.67 \\
\hline 34-Comp. & -11 & 0.59 & -18.64 & -4.46 \\
\hline $35-2 D$ & -12 & 0.52 & -23.08 & -5.52 \\
\hline $36-1 C$ & -11 & 0.52 & -21.15 & -5.06 \\
\hline $36-10$ & -16 & 0.45 & -35.56 & -8.51 \\
\hline $36-2 A$ & -10 & 0.48 & -20.83 & -4.98 \\
\hline $36-2 B$ & -9 & 0.46 & -19.57 & -4.68 \\
\hline $36-2 C$ & No Exotherm & & No Exotherm & No Exotherm \\
\hline $36-20$ & No Exotherm & & No Exotherm & No Exotherm \\
\hline 36-Comp. & -19 & 0.53 & -35.85 & -8.58 \\
\hline
\end{tabular}


Table A-11. Borsheim-Simpson Model Run at 1.0 vol\%. (2 sheets)

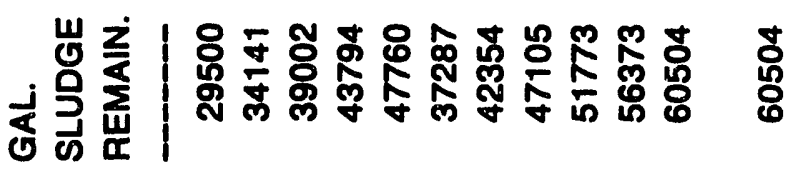

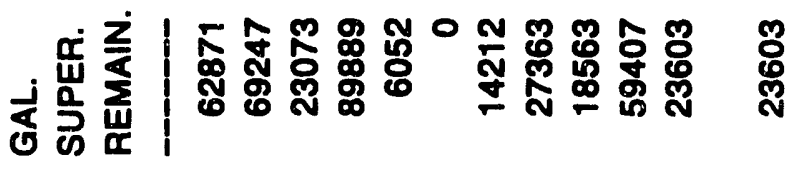

岁岁突|

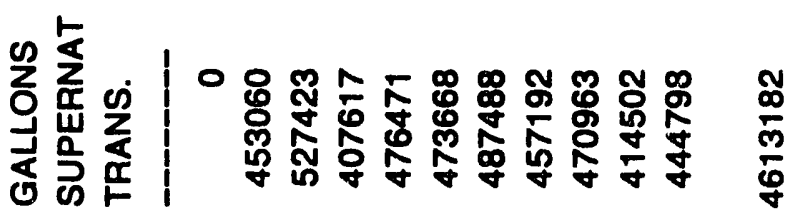

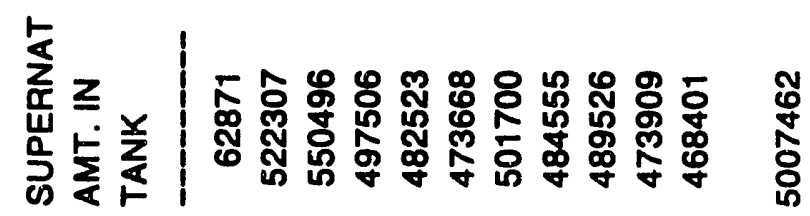

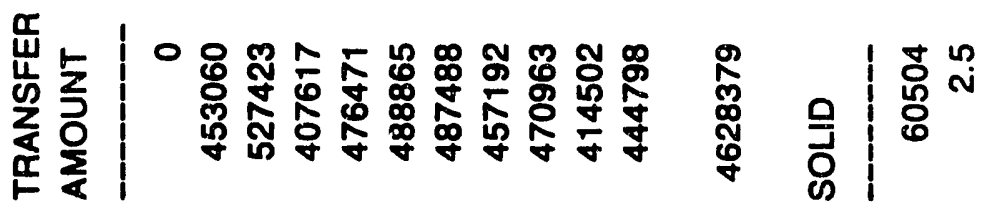

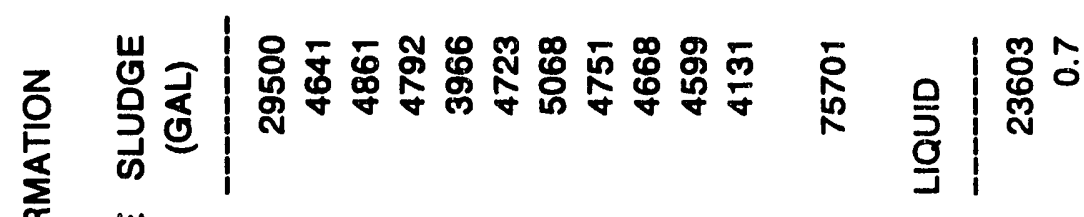

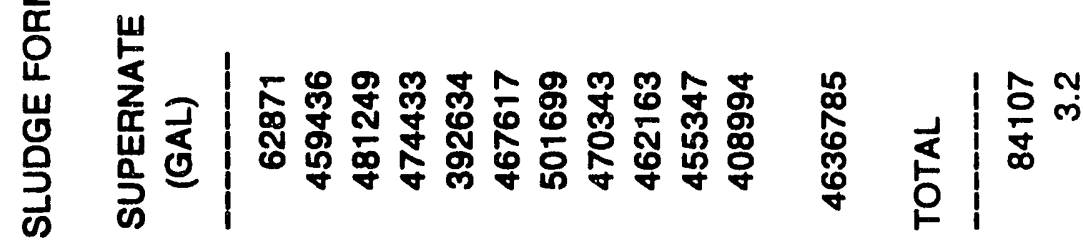

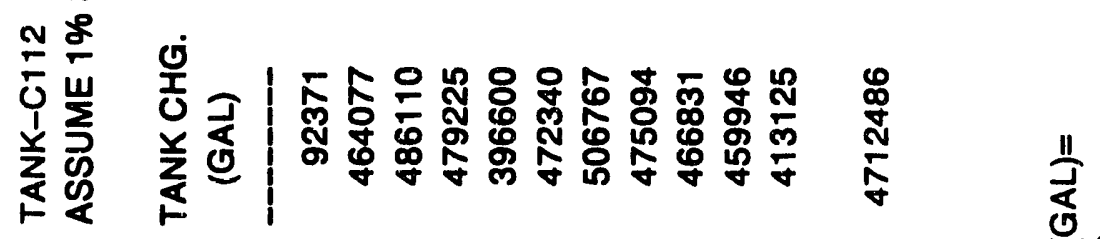

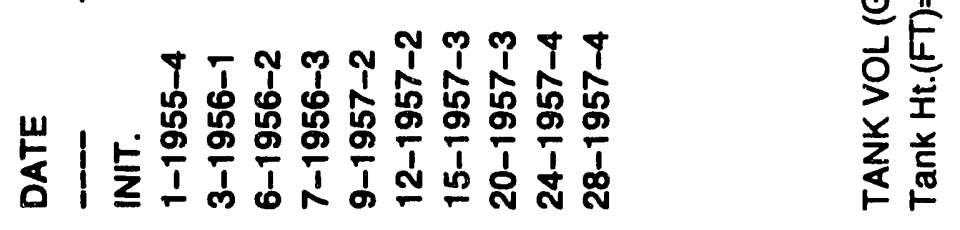




\section{WHC-EP-0640}

Table A-11. Borsheim-Simpson Model Run at 1.0 vol\%.

\begin{tabular}{|c|c|c|c|c|}
\hline $\begin{array}{l}\text { TOTAL } \\
\text { WASTE } \\
\text { REMAIN. }\end{array}$ & $\begin{array}{l}\text { MOLES } \\
\text { Fe(CN)6 } \\
\text { REMAIN. }\end{array}$ & $\begin{array}{l}\text { MOLES } \\
\text { Fe(CN)6 } \\
\text { PRECIP'D }\end{array}$ & $\begin{array}{l}\text { MOLES } \\
\text { FO(CN)6 } \\
\text { TRANS. }\end{array}$ & $\begin{array}{l}\text { DISPOSAL } \\
\text { LOCATION }\end{array}$ \\
\hline 92371 & 0 & 0 & 0 & $C-112$ \\
\hline 103388 & 8783 & 8783 & 0 & $B C-4$ \\
\hline 62075 & 17982 & 9200 & 0 & C108 \\
\hline 133683 & 27052 & 9069 & 0 & BC-3 \\
\hline 53812 & 34557 & 7506 & 0 & $B C-10$ \\
\hline 37287 & 30902 & 8939 & 12595 & $B C-18, B Y 108$ \\
\hline 56566 & 40492 & 9591 & 0 & BY102 \\
\hline 74468 & 40492 & 0 & 0 & $B C-6$ \\
\hline 70336 & 49327 & 8835 & 0 & $B C-6$ \\
\hline 115780 & 58031 & 8704 & 0 & BC-21 \\
\hline 84107 & 65850 & 7818 & 0 & BC-22 \\
\hline 84107 & 65850 & 78445 & 12595 & \\
\hline
\end{tabular}


Table A-12. Borsheim-Simpson Model Run at 1.5 vol\%. (2 sheets)

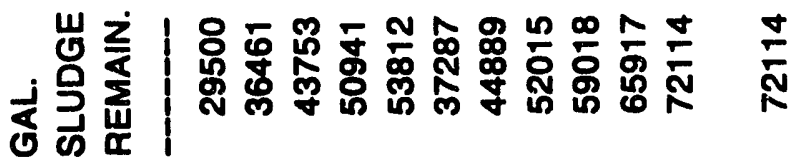

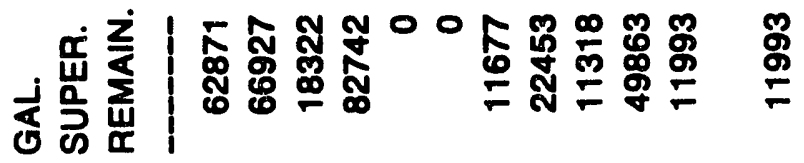

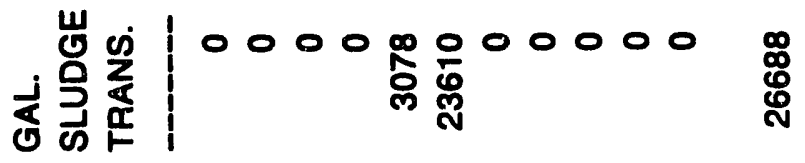

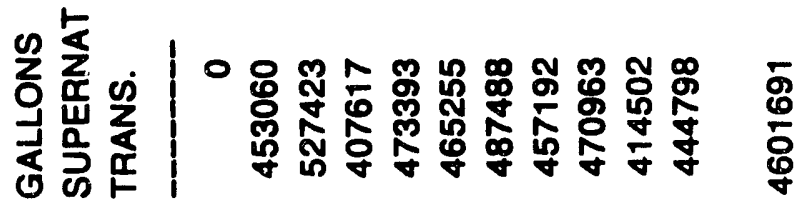

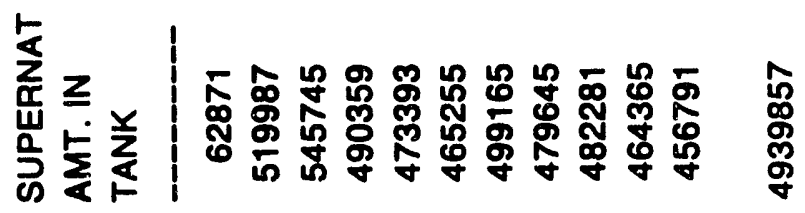

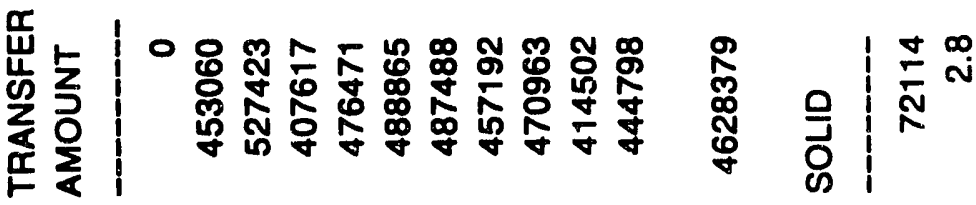

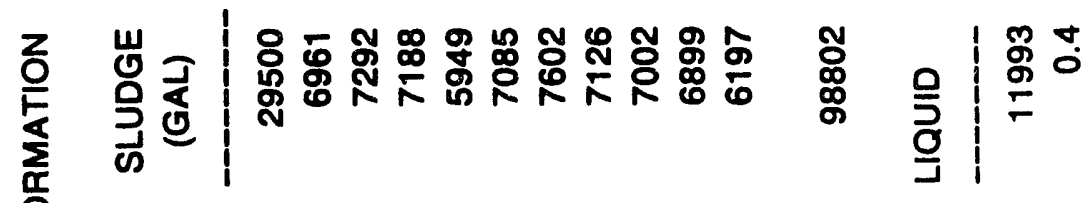

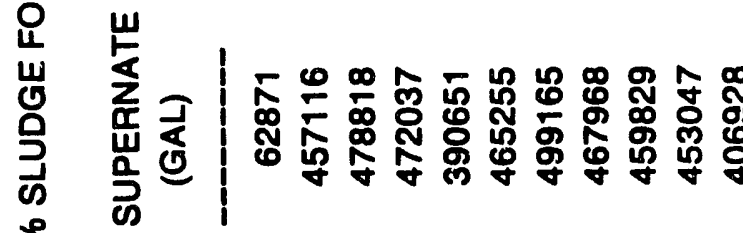

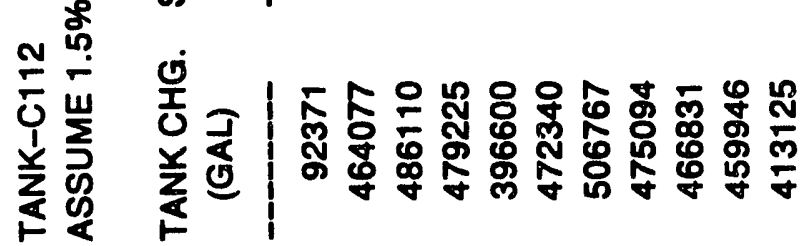

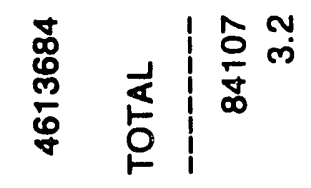

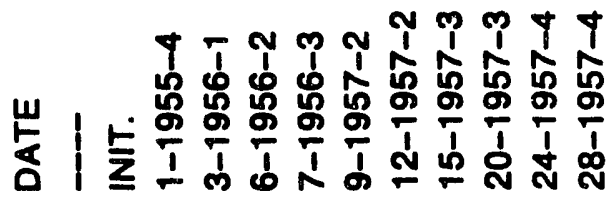

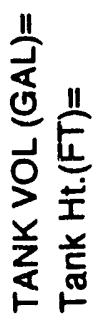


Table A-12. Borsheim-Simpson Model Run at 1.5 vol\%.

\begin{tabular}{|c|c|c|c|c|}
\hline $\begin{array}{l}\text { TOTAL } \\
\text { WASTE } \\
\text { REMAIN. }\end{array}$ & $\begin{array}{l}\text { MOLES } \\
\text { Fe(CN)6 } \\
\text { REMAIN. }\end{array}$ & $\begin{array}{l}\text { MOLES } \\
\text { Fe(CN)6 } \\
\text { PRECIP'D }\end{array}$ & $\begin{array}{l}\text { MOLES } \\
\text { Fe(CN)6 } \\
\text { TRANS. }\end{array}$ & $\begin{array}{l}\text { DISPOSAL } \\
\text { LOCATION }\end{array}$ \\
\hline 92371 & 0 & 0 & 0 & $C-112$ \\
\hline 103388 & 8783 & 8783 & 0 & BC-4 \\
\hline 62075 & 17982 & 9200 & 0 & $C_{108}$ \\
\hline 133683 & 27052 & 9069 & 0 & $B C-3$ \\
\hline 53812 & 32688 & 7506 & 1870 & $B C-10$ \\
\hline 37287 & 25488 & 8939 & 16139 & BC-18,BY108 \\
\hline 56566 & 35078 & 9591 & 0 & BY102 \\
\hline 74468 & 35078 & 0 & 0 & BC-6 \\
\hline 70336 & 43913 & 8835 & 0 & $B C-6$ \\
\hline 115780 & 52618 & 8704 & 0 & BC-21 \\
\hline 84107 & 60436 & 7818 & 0 & BC-22 \\
\hline 84107 & 60436 & 78445 & 18008 & \\
\hline
\end{tabular}


WHC-EP-0640

This page intentionally left blank. 
WHC-EP-0640

APPENDIX B

STATISTICAL INTERPRETATIONS

APP B-i 
WHC-EP-0640

This page intentionally left blank. 
From: Process Laboratories and Technology

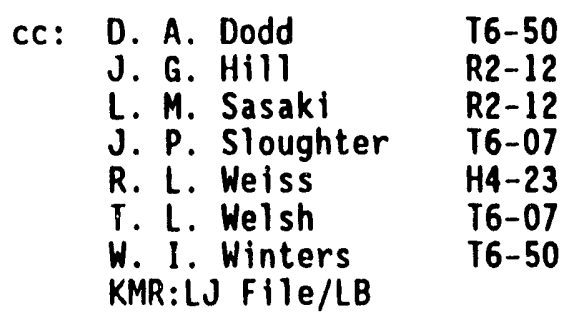

References: (1) Internal Memo, L. Jensen and B. J. Whitcher to A. F. Noonan, "Statistical Analys is of Tank 241-U-110 Data, IV: Concentration Estimates," dated July $23,1993$.

(2) WHC-EP-0210, W. I. Winters, et al., Haste Characterization Plan for the Hanford Site Single-Shell Ianks, Revision 1, dated August 1990.

(3) Book, G. W. Snedecor and W. G. Cochran, Statistical Methods, Seventh Edition, Iowa State University Press, Ames, lowa, dated 1980.

\section{Summary}

This memo contains the results of a statistical analysis of data from three core samples taken from Single-Shell Tank (SST) 241-C-112. The results are divided into four parts.

- The first part contains mean concentration estimates of several analytes found in the SST. In addition, 95\% confidence intervals (CI) on the mean concentration are also given.

- The second part contains the results of a statistical test conducted to determine the Analytical Chemistry Laboratory's (325 Building) ability to homogenize solid core segments. The statistical results indicate that the Analytical Chemistry Laboratory can satisfactorily homogenize core segments.

- Part three contains the results of a statistical test conducted to determine the Analytical Chemistry Laboratory's ability to construct core composite samples from quarter segment samples. 
Eighty-nine percent (25 out of 28 ) of the comparisons showed that the Analytical Chemistry Laboratory's ability to fonstruct core composite samples was satisfactory. The only analytes showing test results to the contrary were $\mathrm{Na}, \mathrm{Cl}$, and $\mathrm{SO}_{4}$ from core 34 .

- The fourth part contains a comparison of the spatial variability (varlability between cores) and the analytical error assoclated with the core samples taken from SST 241-C-112. CIs are given for both sources of variability. In general, the spatial variability in the core composite samples is of the same order of magnitude, or larger, than the analytical error.

\section{Introduction}

Three cores samples (cores 34,35 and 36) were taken from SST 241-C-112. The results from a chemical analysis of the cores are used to obtain mean concentration estimates for analytes in the waste. In addition, the data is used to evaluate the Analytical Chemistry Laboratory's ability to homogenize quarter segments and to construct core composite samples.

The core sample recovery for SST 241-C-112 was incomplete. Quarter segments $10,2 B, 2 C$, and 20 represent core 34 . Quarter segment $2 D$ represents core 35. Quarter segments $1 C, 1 D, 2 A, 2 B, 2 C$, and 20 comprise core 36 . There were also drainable liquids from cores 34 and 35.

Composite samples, for each core, were made from homogenized quarter segment waste. The core composite sample from core 35 is quarter segment 20 . Drainable liquid composite samples were also made for cores 34 and 35 . A sample and duplicate were taken from each core composite and quarter segment. For the homogenization test, additional samples and duplicates were taken from two different locations on each quarter segment.

The laboratory results from SST 241-C-112 samples are tabulated in Attachment 1. The analytes of interest from the Inductively Coupled Plasma (ICP) analyses are $\mathrm{Al}, \mathrm{Ca}, \mathrm{Fe}, \mathrm{Na}, \mathrm{Ni}, \mathrm{Pb}, \mathrm{U}$, and $\mathrm{P}$. The ICP Acid Digestion, and Water Leach analyses were conducted on ail composite core samples. The ICP $\mathrm{KOH} / \mathrm{Ni}$ Fusion Dissolution analyses were performed on the quarter segments and core composite samples from all three cores. The Core 34 composite duplicate results were only reported for the ICP Acid Digestion analyses (see Tables 1,2, and 3 ).

Radio chemistry results for $\mathrm{U}, \mathrm{Pu}-238, \mathrm{Pu}-239 / 240, \mathrm{Cs}-137$, and $\mathrm{Sr}-90$ were reported for core composite samples. The quarter segments were only analyzed (Radio Chemistry) for Cs-137 and Sr-90 (see Table 4).

Each quarter segment and core composite sample was analyzed (Ion Chromatography) for $\mathrm{Cl}, \mathrm{NO}_{2}, \mathrm{NO}_{3}, \mathrm{PO}_{4}, \mathrm{SO}_{4}$ (see Table 5). Table 6 contains ICP Acid Digestion analysis results for the homogenization test. 
Page 3

March 15, 1993

Attachment 7 shows graphically the ICP KOH/Ni Fusion Dissolution, Radio Chemistry, and Ion Chromatography Analyses results for core composite and quarter segment samples. Graphs of the quarter segment homogenization test data are also found in Attachment 7.

\section{Mean Concentration Estimatès}

A task in applying the Waste Characterization Plan to SST 241-C-112 data was to estimate the constituent concentrations (Reference 2, Section 3.3.3). This task was accomplished by computing mean concentrations and $95 \% \mathrm{Cls}$ on the mean concentrations. It should be emphasized that mean concentration estimates of the analytes were computed, not estimates of the inventory of the analytes in the tank.

Tables 1 through 5 contain the core composite data used to compute the mean concentration estimates and the CIs. The "NA" symbol indicates that the data was rot available.

\section{Statistical Methods}

The concentration estimates are given in the form of $95 \% \mathrm{CIs}$ on the mean concentration of analytes. It is assumed that each sample and duplicate are analyzed independently of one another to yield adequate estimates of analytical error. Due to the hierarchical structure of the data, the analytical error alone is not the appropriate error term to use in the CI calculations. A linear combination of the analytical error and spatial variability is the appropriate variance measure for the CIs. The discussion of the formulas used to calculate these CIs is given in the Appendix of Reference 1.

\section{Statistical Results}

Tables $7,8,9,10$, and 11 contain summary statistics, by analyte, for ICP Ac.id Digestion, ICP Water Leach, ICP KOH INi Fusion Dissolution, Radio Chemistry, and Ion Chromatography Anion analyses respectively. The summary statistics are as follows:

$\bar{y}$ : arithmetic mean of the concentration data

BMS: "between mean squares" from the one-way analysis of variance (see Reference 1)

$\partial_{\bar{y}}^{2}: \quad$ estimated variance of $\bar{y}$

df: degrees of freedom associated with BMS

L: $\quad$ lower limit to the $95 \% \mathrm{Cl}$ on the mean

U: $\quad$ upper limit to the $95 \% \mathrm{Cl}$ on the mean 
For some analytes the lower confidence limit (L) was negative. Since concentrations are strictly greater than or equal to zero, any negative $L$ values were set equal to zero.

ICP Acid Digestion drainable liquid composite (DLC) results for $\mathrm{Ca}, \mathrm{Fe}, \mathrm{Ni}$, $U$, and $P$ were one or two orders of magnitude smaller than the solid core composite results. For this reason, two sets of summary statistics are given for ICF Acid Digestion and ICP Water Leach anaiysis methods. One set includes the DLC results and the other set excludes them. In all but two cases, the upper confidence limit for the analysis including the DLCs was smaller than upper confidence limit for the analysis excluding the DLCs.

The concentration confidence limits for uranium should be viewed with caution. This interval is based on only three core composite sample results from cores 34 and 36 . The upper confidence limit is far beyond the range of the three sample results due to the small sample size.

\section{Homogen:zation Test}

A second task in applying the Waste Characterization Plan to core samples from Tank 241-C-112 was to evaluate the ability of the Analytical Chemistry Laboratory to homogenize quarter segments (Reference 2, Section 3.3.4).

Each quarter segment, from cores 34,35 , and 36 was homogenized and arbitrarily divided into two parts. One sub-sample was obtained from each part. Two aliquots were taken from each sub-sample and prepared for chemical analysis. The homogenization test data described above is tabulated in Table 6 (Attachment 1). ICP Acid Digestion analyses were conducted on the aliquots for the following analytes: $\mathrm{Al}, \mathrm{Fe}, \mathrm{Na}, \mathrm{Ni}, \mathrm{Pb}, \mathrm{U}, \mathrm{P}$.

\section{Statistical Methods and Resuits}

Due to the hierarchical structure (sub-samples within quarter segments, aliquots within sub-samples), a hierarchical statistical model was fit to the data. Reference 3 (page 284) contains a description of the hierarchical statistical model. This model is used to separate different components of variability in the data. The total variability in the data is decomposed into three components: one due to variability between quarter segments, one due to the variability between samples taken from different locations on each homogenized quarter segment $\left(\sigma^{2}\right)$, and one due to the analytical error. The analytical error accounts for the differences between aliquots taken from the same location. These three components of varlability, as a percent of the total, are given in Table 12. It should be noted that the largest contributor to the total variability, is the between segment variability, not that due to the homogenization.

To quantify the contribution of $\sigma_{l}^{2}$ (the component of varlability due to location or homogenization), the analys is of variance (ANOVA) corresponding to the hierarchical model is ysed. From the ANOVA, a test can be constructed to determine if $\sigma_{L}^{2}$ is significantiy different from 0 . If $\sigma_{l}^{2}$ is significaritly different from zero then it is concluded that the jaboratory does not have the ability to homogenizo quarter segments. If $\sigma_{L}^{2}$ is not 
Page 5

March 15, 1993

significantly different from zero, it is concluded that the laboratory has the ability to homogenize core segments. An F-test was used to test significance of $\sigma_{\mathrm{L}}^{2}$. The $p$-values (the attained level of significances), from these tests are given in Table 12. If the $p$-value is smaller than 0.05 then $\sigma_{1}^{2}$ is significantly different from zero. For each analyte, the F-test indicated that $\sigma_{L}^{2}$ is not significantly different from zero. This indicates that the Analytical Chemistry Laboratory can adequately homogenize core segments.

\section{Core Composite Construction Test}

Another task in applying the Waste Characterization Plan to core samples from Tank 241-C-112 was to evaluate the ability of the Analytical Chemistry Laboratory to make core composites from the individual quarter segment samples (Reference 2, Section 3.3.7.2). Core composites were formed by combining equally weighted samples from each homogenized quarter segment in the core. Each core composite was then homogenized. A sample and duplicate were then taken from each core composite.

A simulated core composite (SCC) was statistically constructed to compare with to the corresponding core composite result. For each core, the SCCs are the average of all quarter segment results for each analyte of interest. This mean or average is denoted by $\bar{F}_{w}$. The subscript " $w^{\prime \prime}$ is used since $\bar{J}_{W}$ is generally a weighted mean. However, in this case the weights are all equal. An " $i$ " subscript should be included for $\bar{y}_{4}$ to denote the different SCCs calculated for each core. This subscript is excluded to simplify notation.

\section{Statistical Methods}

The chemical analysis methods used to analyze quarter segment samples (ICP $\mathrm{KOH} / \mathrm{Ni}$ Fusion Dissolution, Radio Chemistry, Ion Chromatography) did not report duplicate core 34 composite results. For this reason, the method used to compare the core composite with the SCC for core 36 is different then the method used for core 34 .

\section{Core 34 Statistical Methods}

A CI on the SCC is calculated to make the comparison between the core composite and the SCC from core 34 . If the core composite sample result is contained within the $\mathrm{CI}$, we conclude that the laboratory can satisfactorily construct a core composite (i.e., SCC cannot be statistically distinguished from the core composite). If the core composite result is not contained within the $\mathrm{Cl}$, we conclude that the laboratory cannot satisfactorily construct core composites (i.e., there is a significant difference between the core composite sample and SCC). 
The $\mathrm{CI}$ on the SCC is $(L, U)$ where the lower $(L)$ and $(U)$ values are

$$
L=\bar{y}_{w}-t \sqrt{\partial^{2}\left(\bar{y}_{w}\right)}, \quad U=\bar{y}_{w}+t \sqrt{\partial^{2}\left(\bar{y}_{w}\right)}
$$

where $\partial^{2}\left(\Phi_{u}\right)$ is the estimated variance of $g_{\mu}$, aind " $t$ " is the appropriate percentile point from Student's t-distribution. The Appendix (Attachment 6) outlines the method used to calculate $\partial^{2}\left(\bar{y}_{u}\right)$.

\section{Core 36 Statistical Methods}

For Core 36, the comparison between the core composite and SCC is made by computing a $\mathrm{CI}$ on the difference between the SCC and the mean of the composite sample. If zero is in the $\mathrm{CI}$, it is concluded that the laboratory can construct core composites satisfactorily (i.e., the SCC cannot be statistically distinguished from the core composite sample mean). If zero is not in the CI, it is concluded that the laboratory cannot satisfactorily construct core composites (i.e., the two means are significantly different).

The $C I$ for this difference is $(L, U)$ where the lower $(L)$ and $(U)$ values are

$$
L=\left(\bar{y}_{w}-\bar{y}_{c}\right)-t \sqrt{\partial^{2}\left(\bar{y}_{w}-\bar{y}_{c}\right)}, \quad U=\left(\bar{y}_{w}-\bar{y}_{c}\right)+t \sqrt{\partial^{2}\left(\bar{y}_{w}-\bar{y}_{c}\right)}
$$

where

$$
\begin{array}{ll}
\bar{y}_{c}: & \text { mean of the two core composite sample results, } \\
t: & \text { percentile point from Student's } t \text { distribution, and } \\
\hat{\sigma}^{2}\left(\bar{y}_{w}-\bar{y}_{c}\right): & \text { is the estimated variance of the difference. }
\end{array}
$$

The Appendix (Attachment ${ }^{6}$ ) outlines the method used to calculate $\partial^{2}\left(\bar{y}_{4}-\bar{y}_{1}\right)$. The estimated variance $\delta^{2}\left(\bar{y}_{w}-\bar{y}_{f}\right)$ was calculated using the data from all three cores because of the limited information available. The degrees of freedom (df) associated. with " $t$ " were calculated using Satterhwaite's approximation (Reference 3, page 228).

\section{Statistical Results}

Table 13 (Attachment 4) contains summary statistics for core 34 , including the $95 \% \mathrm{CI}(\mathrm{L}, \mathrm{U})$ on the SCC. There were only three analytes $\left(\mathrm{Na}, \mathrm{Cl}, \mathrm{SO}_{4}\right)$ which had composite sample results that were outside of the CI limits. In all three cases the composite sample exceeded the upper limit of the CI. In other words, the core composite sample is significantly greater than the SCC for core $34 \mathrm{Na}, \mathrm{Cl}$ and $\mathrm{SO}_{4}$.

Table 14 (Attachment 4) contains summary statistics for core 36 , including the 95\% CI Interval $(L, U)$ on the difference between the SCC mean and the core composite mean. All of the CIs on this difference contained zero. 
This indicates that there were not significant differences between the two means (i.e., the Analytical Chemistry Laboratory can construct a core composite sample from material similar to core 36).

Attachment 7 contains figures of the segment and core composite data for all three cores which may aid in understanding the results from Tables 13 and 14.

Overall, the simulated core composite could not be statistically distinguished from the core composite in $89 \%$ (25 out of 28) of the cases tested. We generally conclude that the Analytical Chemistry Laboratory's ability to construct core composites is satisfactory.

\section{Spatial Variability and Analytical Error Estimation}

Using the hierarchical structure of the core composite data, the spatial variabllity and the analytical error can be separated from each other. The spatial variability is the variability between cores. The analytical error includes among other things, the segment homogenization error, the sample handiling error, and the chemical analysis error.

The size of the analytical error relative to the spatial variability has an impact on the mean concentration CIs for each analyte. The variance used in these CI calculations is a linear function of spatial and analytical error estimates. Since the size of the analytical error can potentially be controlled, this comparison is interesting to discuss.

\section{Statistical Methods}

Estimates of the spatial variability $\left(\hat{\sigma}_{s}^{2}\right)^{1}$ and analytical error $\left(\partial^{2}\right)$ were obtained for each analyte by solving a system of equations using the expected mean squares from hierarchical model ANOVA results. This method is explained in Reference 3 (page 246).

Reference 3 (page 246) also explains methods usęd to obtain CIs for $\sigma_{3}^{2}$ and $\sigma_{0}^{2}$. The CI for $\sigma_{3}^{2}$ is approximate. The CI for $\sigma_{0}^{2}$ is exact.

\section{Statistical Results}

Tables 15, 16, 17, 18 and 19 (Attachment 5) contain 95\% CIs for $\sigma^{2}$ and $\sigma^{2}$ for al1 14 analytes and chemical analysis methods. For the ICP Acid bigestion and ICP Water Leach analyses results were tabulated including the DLCs and excluding the DLCs.

Using the variance component estimation methods described above, it is possible to obtain negative variance estimates. Negative variance estimates and negative lower CI limits were set equal to zero.

'An estimate of a variance component is indicated by a "A" over the variance component symbol $\sigma^{2}$. 
B. C. Simpson

Page 8

March 15, 1993

For the Acid Digestion analysis (Tables 15), including and excluding the DLCs change the values of $\partial^{2}$ and $\partial^{2}$. When the DLCs were included, $\sigma^{2}$ generally decreased in magnitude and $\partial_{\text {s }}^{2}$ generally increased in magnitude.

For the Radio Chemistry uranium analysis, an estimate and approximate CI for $\sigma_{s}^{2}$ were not obtained due to the small amount of data.

In general, the upper limits $(U)$ on the approximate $95 \%$ CIs for $\sigma^{2}$ were larger than the 95\% CI upper limits for $\sigma^{2}$ (86\% of the cases). From this result it can be generally concluded that the spatial varjability $\left(\sigma_{s}^{2}\right)$ is the same magnitude or larger than the analytical error $\left(\sigma_{*}^{2}\right)$ from the core composite samples.
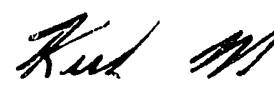

K. M. Remund, Advanced Statistician Process Laboratories and Technology

114

Attachments 7

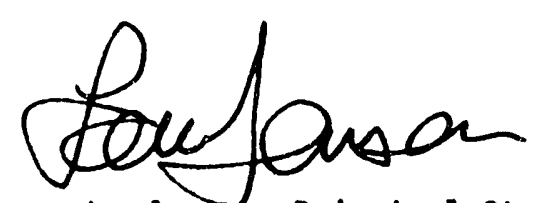

L. Jenseh, Principal Statistician Process Laboratories and Technology 
Table 1. Acid Digestion Core Composite Data

\begin{tabular}{|c|r|r|r|r|}
\hline \multirow{2}{*}{ Core } & \multicolumn{4}{|c|}{ ICP Anaiys is $(\mu \mathrm{g} / \mathrm{g})$} \\
\cline { 2 - 5 } & \multicolumn{1}{|c|}{ AI } & \multicolumn{1}{|c|}{ Ca } & Fe & \multicolumn{1}{c|}{ Na } \\
\hline $34 *$ & NA & 307 & 1055 & 82310 \\
& NA & 297 & 1059 & 82816 \\
34 & 24173 & 22462 & 26227 & 97347 \\
& 22378 & 20838 & 13920 & 92815 \\
$35 *$ & NA & 394 & 741 & 70213 \\
& NA & 433 & 750 & 69613 \\
35 & 37836 & 12422 & 27893 & 76362 \\
& 51345 & 10673 & 24166 & 65283 \\
36 & 5385 & 16174 & 19600 & 102729 \\
& 5667 & 17888 & 19315 & 102864 \\
\hline
\end{tabular}

\begin{tabular}{|c|r|r|r|r|}
\hline \multirow{2}{*}{ Core } & \multicolumn{4}{|c|}{ ICP Analysis $(\mu \mathrm{g} / \mathrm{g})$} \\
\cline { 2 - 5 } & $\mathrm{Ni}$ & $\mathrm{Pb}$ & $\mathrm{U}$ & \multicolumn{1}{c|}{$\mathrm{P}$} \\
\hline $34 *$ & 637 & $\mathrm{NA}$ & 1136 & 3709 \\
34 & 636 & $\mathrm{NA}$ & 1132 & 3712 \\
& 18242 & 3128 & 12412 & 19319 \\
$35 *$ & 17202 & 2793 & 11809 & 18878 \\
35 & 437 & $\mathrm{NA}$ & 932 & 3977 \\
& 11707 & $\mathrm{NA}$ & 924 & 3941 \\
36 & 10397 & 3904 & 89549 & 20996 \\
& 9620 & 3739 & 68790 & 16622 \\
& 11511 & 840 & 91473 & 31796 \\
& \multicolumn{2}{|c|}{913} & 76301 & 29882 \\
\hline
\end{tabular}


Table 2. KOH/Ni Fusion Dissolution Core Composite and Quarter

\section{Segment Data}

\begin{tabular}{|c|c|c|c|c|c|c|c|c|}
\hline \multirow[t]{2}{*}{ Core } & \multirow{2}{*}{$\begin{array}{l}\text { Quarter } \\
\text { Segment }\end{array}$} & \multicolumn{7}{|c|}{ ICP Analys is $(\mu \mathrm{g} / \mathrm{g})$} \\
\hline & & Al & $\mathrm{Ca}$ & $\mathrm{Fe}$ & $\mathrm{Na}$ & $\mathrm{Pb}$ & $\underline{U}$ & $\mathbf{p}$ \\
\hline \multirow[t]{5}{*}{34} & 10 & $\begin{array}{l}19074 \\
16222 \\
\end{array}$ & $\begin{array}{l}26041 \\
30357 \\
\end{array}$ & $\begin{array}{l}8743 \\
8297 \\
\end{array}$ & $\begin{array}{l}90862 \\
91101 \\
\end{array}$ & $\begin{array}{r}1494 \\
N A \\
\end{array}$ & $\begin{array}{l}N A \\
\text { NA } \\
\end{array}$ & $\begin{array}{l}11987 \\
13523 \\
\end{array}$ \\
\hline & 2B & $\begin{array}{r}32484 \\
32241 \\
\end{array}$ & $\begin{array}{l}21620 \\
21787 \\
\end{array}$ & $\begin{array}{l}14862 \\
14592 \\
\end{array}$ & $\begin{array}{l}86858 \\
91136 \\
\end{array}$ & $\begin{array}{l}3768 \\
3477 \\
\end{array}$ & $\begin{array}{l}\text { NA } \\
\text { NA } \\
\end{array}$ & 11551 \\
\hline & $2 C$ & $\begin{array}{l}14143 \\
20495 \\
\end{array}$ & $\begin{array}{r}30638 \\
29142 \\
\end{array}$ & $\begin{array}{r}9798 \\
10701 \\
\end{array}$ & $\begin{array}{r}79272 \\
100681 \\
\end{array}$ & $\begin{array}{l}\text { NA } \\
\text { NA } \\
\end{array}$ & $\begin{array}{l}\text { NA } \\
\text { NA } \\
\end{array}$ & $\begin{array}{l}19738 \\
19752 \\
\end{array}$ \\
\hline & 20 & $\begin{array}{l}26418 \\
27318 \\
\end{array}$ & $\begin{array}{l}23631 \\
23936 \\
\end{array}$ & $\begin{array}{l}18483 \\
20887 \\
\end{array}$ & $\begin{array}{l}78902 \\
78213 \\
\end{array}$ & $\begin{array}{l}2791 \\
2842 \\
\end{array}$ & $\begin{array}{l}20464 \\
19732 \\
\end{array}$ & $\begin{array}{l}19809 \\
19101 \\
\end{array}$ \\
\hline & Comp. & 29798 & 28984 & 22847 & 114891 & 3326 & 14369 & 21956 \\
\hline 35 & 20 & $\begin{array}{l}45791 \\
44289 \\
\end{array}$ & $\begin{array}{l}14676 \\
15310 \\
\end{array}$ & $\begin{array}{l}29941 \\
34764 \\
\end{array}$ & $\begin{array}{l}81974 \\
81142 \\
\end{array}$ & $\begin{array}{r}4261 \\
5001 \\
\end{array}$ & $\begin{array}{l}86289 \\
93172 \\
\end{array}$ & $\begin{array}{l}21854 \\
22526 \\
\end{array}$ \\
\hline \multirow[t]{7}{*}{36} & IC & $\begin{array}{l}14990 \\
14372 \\
\end{array}$ & $\begin{array}{l}29758 \\
28109 \\
\end{array}$ & $\begin{array}{r}34125 \\
38006 \\
\end{array}$ & $\begin{array}{l}82377 \\
80370 \\
\end{array}$ & $\begin{array}{l}2733 \\
2830 \\
\end{array}$ & $\begin{array}{l}N A \\
\text { NA } \\
\end{array}$ & $\begin{array}{l}19155 \\
19349 \\
\end{array}$ \\
\hline & 10 & $\begin{array}{l}4013 \\
3898 \\
\end{array}$ & $\begin{array}{l}28897 \\
28246 \\
\end{array}$ & $\begin{array}{l}7364 \\
7656 \\
\end{array}$ & $\begin{array}{l}82799 \\
80602 \\
\end{array}$ & $\begin{array}{l}N A \\
N A \\
\end{array}$ & $\begin{array}{l}N A \\
\text { NA } \\
\end{array}$ & $\begin{array}{l}19480 \\
19155 \\
\end{array}$ \\
\hline & $2 A$ & $\begin{array}{l}2999 \\
2857 \\
\end{array}$ & $\begin{array}{l}22411 \\
20289 \\
\end{array}$ & $\begin{array}{l}11750 \\
10847 \\
\end{array}$ & $\begin{array}{l}91675 \\
91998 \\
\end{array}$ & $\begin{array}{l}\text { NA } \\
\text { NA }\end{array}$ & $\begin{array}{l}41400 \\
38267 \\
\end{array}$ & $\begin{array}{l}22300 \\
20053 \\
\end{array}$ \\
\hline & $2 B$ & $\begin{array}{l}3040 \\
3088 \\
\end{array}$ & $\begin{array}{l}8710 \\
9113 \\
\end{array}$ & $\begin{array}{l}8881 \\
8940 \\
\end{array}$ & $\begin{array}{l}90051 \\
91138 \\
\end{array}$ & $\begin{array}{l}N A \\
\text { NA } \\
\end{array}$ & $\begin{array}{l}171775 \\
177587 \\
\end{array}$ & $\begin{array}{l}24748 \\
25720 \\
\end{array}$ \\
\hline & $2 C$ & $\begin{array}{l}2111 \\
2039 \\
\end{array}$ & $\begin{array}{l}3001 \\
3020 \\
\end{array}$ & $\begin{array}{l}15655 \\
14605 \\
\end{array}$ & $\begin{array}{l}105515 \\
105889 \\
\end{array}$ & $\begin{array}{l}\text { NA } \\
\text { NA }\end{array}$ & $\begin{array}{l}115926 \\
108452 \\
\end{array}$ & $\begin{array}{l}34517 \\
32602 \\
\end{array}$ \\
\hline & 20 & $\begin{array}{l}2944 \\
3023 \\
\end{array}$ & $\begin{array}{l}2123 \\
2134 \\
\end{array}$ & $\begin{array}{r}30859 \\
31572 \\
\end{array}$ & $\begin{array}{l}104335 \\
105942 \\
\end{array}$ & $\begin{array}{l}771 \\
817 \\
\end{array}$ & $\begin{array}{l}57961 \\
59672 \\
\end{array}$ & $\begin{array}{l}29587 \\
30127 \\
\end{array}$ \\
\hline & Comp. & $\begin{array}{l}6356 \\
6464\end{array}$ & $\begin{array}{l}20155 \\
20626\end{array}$ & $\begin{array}{l}28011 \\
24012\end{array}$ & $\begin{array}{l}118784 \\
122676\end{array}$ & $\begin{array}{r}1151 \\
947\end{array}$ & $\begin{array}{l}107042 \\
102778\end{array}$ & $\begin{array}{l}36604 \\
36917\end{array}$ \\
\hline
\end{tabular}

Comp.: core composite sample data 
Table 3. Water Leach Core Composite Data

\begin{tabular}{|c|c|c|c|c|}
\hline \multirow[t]{2}{*}{ Core } & \multicolumn{4}{|c|}{ ICP Analysis $(\mu g / g)$} \\
\hline & A1 & Ca & $\mathrm{Fe}$ & $\mathrm{Na}$ \\
\hline $\begin{array}{l}34 \\
34 * \\
35 \\
35 * \\
36\end{array}$ & $\begin{array}{r}315 \\
\text { NA } \\
\text { NA } \\
333 \\
327 \\
\text { NA } \\
\text { NA } \\
988 \\
639\end{array}$ & $\begin{array}{r}240 \\
N A \\
N A \\
304 \\
374 \\
44 \\
37 \\
194 \\
577\end{array}$ & $\begin{array}{r}1630 \\
1210 \\
1196 \\
703 \\
722 \\
788 \\
791 \\
1452 \\
1336\end{array}$ & $\begin{array}{r}104939 \\
86016 \\
85326 \\
60689 \\
60364 \\
71152 \\
71500 \\
130962 \\
85753\end{array}$ \\
\hline
\end{tabular}

\begin{tabular}{|c|c|c|c|c|}
\hline \multirow[t]{2}{*}{ Core } & \multicolumn{4}{|c|}{ ICP Analys is $(\mu \mathrm{g} / \mathrm{g})$} \\
\hline & $\mathrm{NI}$ & $\mathrm{Pb}$ & $\underline{\mathbf{U}}$ & $p$ \\
\hline $\begin{array}{l}34 \\
34 \star \\
35 \\
35 \star \\
36\end{array}$ & $\begin{array}{l}999 \\
793 \\
784 \\
403 \\
411 \\
491 \\
493 \\
827 \\
756\end{array}$ & $\begin{array}{l}N A \\
N A \\
N A \\
N A \\
N A \\
N A \\
N A \\
N A \\
N A\end{array}$ & $\begin{array}{r}715 \\
1148 \\
1123 \\
476 \\
444 \\
978 \\
981 \\
6207 \\
2986 \\
\end{array}$ & $\begin{array}{r}6380 \\
3796 \\
3820 \\
5705 \\
5556 \\
3986 \\
4111 \\
19807 \\
13093 \\
\end{array}$ \\
\hline
\end{tabular}


12100-PLT93-020

ATTACHMENT 1

Page 4 of 7

Table 4. Radio Chemistry Core Composite and Quarter Segmen̈t Data

\begin{tabular}{|c|c|c|c|c|c|c|}
\hline \multirow[t]{2}{*}{ Core } & \multirow{2}{*}{$\begin{array}{l}\text { Quarter } \\
\text { Segments }\end{array}$} & \multicolumn{5}{|c|}{$(\mu \mathrm{Cl} / \mathrm{g})$} \\
\hline & & U & $P u-238$ & $\mathrm{Pu}-239 / 240$ & Cs-137 & $S r-90$ \\
\hline \multirow[t]{5}{*}{34} & 10 & $\begin{array}{l}\text { NA } \\
\text { NA }\end{array}$ & $\begin{array}{l}N A \\
N A\end{array}$ & $\begin{array}{l}N A \\
N A\end{array}$ & $\begin{array}{l}169 \\
316\end{array}$ & $\begin{array}{r}1640 \\
991\end{array}$ \\
\hline & $2 B$ & $\begin{array}{l}\text { NA } \\
\text { NA }\end{array}$ & $\begin{array}{l}\text { NA } \\
\text { NA }\end{array}$ & $\begin{array}{l}\text { NA } \\
\text { NA }\end{array}$ & $\begin{array}{l}613 \\
611\end{array}$ & $\begin{array}{l}4950 \\
4770\end{array}$ \\
\hline & $2 C$ & $\begin{array}{l}N A \\
\text { NA }\end{array}$ & $\begin{array}{l}\text { NA } \\
\text { NA }\end{array}$ & $\begin{array}{l}\text { NA } \\
\text { NA }\end{array}$ & $\begin{array}{l}801 \\
788 \\
\end{array}$ & $\begin{array}{l}1130 \\
1150\end{array}$ \\
\hline & 20 & $\begin{array}{l}\text { NA } \\
\text { NA }\end{array}$ & $\begin{array}{l}N A \\
\text { NA }\end{array}$ & $\begin{array}{l}\text { NA } \\
\text { NA }\end{array}$ & $\begin{array}{l}513 \\
502 \\
\end{array}$ & $\begin{array}{l}2450 \\
2570 \\
\end{array}$ \\
\hline & Comp. & 17.7 & 0.0137 & 0.1550 & 750 & 3510 \\
\hline 35 & 20 & $\begin{array}{l}\text { NA } \\
\text { NA }\end{array}$ & $\begin{array}{l}0.1470 \\
0.1550 \\
\end{array}$ & $\begin{array}{l}0.0130 \\
0.0143\end{array}$ & $\begin{array}{l}686 \\
716 \\
\end{array}$ & $\begin{array}{l}3220 \\
3200 \\
\end{array}$ \\
\hline \multirow[t]{7}{*}{36} & $1 C$ & $\begin{array}{l}N A \\
N A\end{array}$ & $\begin{array}{l}N A \\
N A\end{array}$ & $\begin{array}{l}N A \\
N A\end{array}$ & $\begin{array}{l}579 \\
546 \\
\end{array}$ & $\begin{array}{l}1800 \\
1910 \\
\end{array}$ \\
\hline & 10 & $\begin{array}{l}\text { NA } \\
\text { NA }\end{array}$ & $\begin{array}{l}\text { NA } \\
\text { NA }\end{array}$ & $\begin{array}{l}\text { NA } \\
\text { NA }\end{array}$ & $\begin{array}{l}1250 \\
1230 \\
\end{array}$ & $\begin{array}{l}14 \\
16 \\
\end{array}$ \\
\hline & $2 A$ & $\begin{array}{l}N A \\
N A \\
\end{array}$ & $\begin{array}{l}\text { NA } \\
\text { NA }\end{array}$ & $\begin{array}{l}\text { NA } \\
\text { NA }\end{array}$ & $\begin{array}{l}933 \\
835 \\
\end{array}$ & $\begin{array}{l}15 \\
24 \\
\end{array}$ \\
\hline & $2 B$ & $\begin{array}{l}\text { NA } \\
\text { NA }\end{array}$ & $\begin{array}{l}N A \\
\text { NA } \\
\end{array}$ & $\begin{array}{l}N A \\
N A \\
\end{array}$ & $\begin{array}{l}529 \\
535 \\
\end{array}$ & $\begin{array}{l}71 \\
70 \\
\end{array}$ \\
\hline & $2 C$ & $\begin{array}{l}\text { NA } \\
\text { NA }\end{array}$ & $\begin{array}{l}\text { NA } \\
\text { NA }\end{array}$ & $\begin{array}{l}\text { NA } \\
\text { NA }\end{array}$ & $\begin{array}{l}105 \\
100 \\
\end{array}$ & $\begin{array}{l}148 \\
139 \\
\end{array}$ \\
\hline & 2D & $\begin{array}{l}\text { NA } \\
\text { NA }\end{array}$ & $\begin{array}{l}\text { NA } \\
\text { NA }\end{array}$ & $\begin{array}{l}\text { NA } \\
\text { NA }\end{array}$ & $\begin{array}{l}35 \\
35\end{array}$ & $\begin{array}{l}195 \\
203\end{array}$ \\
\hline & Comp. & $\begin{array}{l}88.9 \\
99.2\end{array}$ & $\begin{array}{l}0.0033 \\
0.0034\end{array}$ & $\begin{array}{l}0.0644 \\
0.0541\end{array}$ & $\begin{array}{l}795 \\
790\end{array}$ & $\begin{array}{l}543 \\
472\end{array}$ \\
\hline
\end{tabular}

Comp.: core composite sample data 
Table 5. Ion Chromatography Data

\begin{tabular}{|c|c|c|c|c|c|c|}
\hline \multirow[t]{2}{*}{ Core } & \multirow{2}{*}{$\begin{array}{l}\text { Quarter } \\
\text { Segment }\end{array}$} & \multicolumn{5}{|c|}{$(\mu g / g)$} \\
\hline & & $\mathrm{Cl}$ & $\mathrm{NO}_{2}$ & $\mathrm{NO}_{3}$ & $\mathrm{PO}_{\mathrm{b}}$ & $\mathrm{SO}_{\mathrm{L}}$ \\
\hline \multirow[t]{6}{*}{34} & 10 & $\begin{array}{l}1100 \\
1100 \\
\end{array}$ & $\begin{array}{l}61000 \\
59000 \\
\end{array}$ & $\begin{array}{l}80000 \\
78000 \\
\end{array}$ & $\begin{array}{l}10800 \\
12500 \\
\end{array}$ & $\begin{array}{l}14200 \\
14600 \\
\end{array}$ \\
\hline & $2 B$ & $\begin{array}{l}1000 \\
1000 \\
\end{array}$ & $\begin{array}{l}53000 \\
54000 \\
\end{array}$ & $\begin{array}{l}69000 \\
70000 \\
\end{array}$ & $\begin{array}{l}12000 \\
12200 \\
\end{array}$ & $\begin{array}{l}13100 \\
13000 \\
\end{array}$ \\
\hline & $2 C$ & $\begin{array}{l}900 \\
900 \\
\end{array}$ & $\begin{array}{l}48000 \\
49000 \\
\end{array}$ & $\begin{array}{l}64000 \\
65000 \\
\end{array}$ & $\begin{array}{l}11200 \\
11900 \\
\end{array}$ & $\begin{array}{l}11600 \\
11900 \\
\end{array}$ \\
\hline & 20 & $\begin{array}{l}800 \\
900 \\
\end{array}$ & $\begin{array}{l}44000 \\
47000 \\
\end{array}$ & $\begin{array}{l}58000 \\
61000 \\
\end{array}$ & $\begin{array}{l}16500 \\
18500 \\
\end{array}$ & $\begin{array}{l}10700 \\
11600 \\
\end{array}$ \\
\hline & Comp. & 1300 & 62000 & 80000 & 19100 & 15600 \\
\hline & DLC & $\begin{array}{l}1000 \\
1000 \\
\end{array}$ & $\begin{array}{l}55000 \\
55000 \\
\end{array}$ & $\begin{array}{l}72000 \\
72000 \\
\end{array}$ & $\begin{array}{l}11700 \\
11600 \\
\end{array}$ & $\begin{array}{l}11700 \\
11600 \\
\end{array}$ \\
\hline \multirow[t]{2}{*}{35} & $2 D$ & $\begin{array}{l}800 \\
700 \\
\end{array}$ & $\begin{array}{l}34000 \\
35000 \\
\end{array}$ & $\begin{array}{l}43000 \\
44000 \\
\end{array}$ & $\begin{array}{l}18100 \\
17600 \\
\end{array}$ & $\begin{array}{l}8600 \\
8600 \\
\end{array}$ \\
\hline & DLC & $\begin{array}{l}900 \\
900 \\
\end{array}$ & $\begin{array}{l}46000 \\
46000 \\
\end{array}$ & $\begin{array}{l}58000 \\
59000 \\
\end{array}$ & $\begin{array}{l}12900 \\
13000 \\
\end{array}$ & $\begin{array}{l}10900 \\
10900 \\
\end{array}$ \\
\hline \multirow[t]{7}{*}{36} & $1 C$ & $\begin{array}{l}900 \\
900 \\
\end{array}$ & $\begin{array}{l}50000 \\
46000 \\
\end{array}$ & $\begin{array}{l}64000 \\
60000 \\
\end{array}$ & $\begin{array}{l}17700 \\
15500 \\
\end{array}$ & $\begin{array}{l}12600 \\
11500 \\
\end{array}$ \\
\hline & 10 & $\begin{array}{r}900 \\
1000 \\
\end{array}$ & $\begin{array}{l}49000 \\
53000 \\
\end{array}$ & $\begin{array}{l}64000 \\
69000 \\
\end{array}$ & $\begin{array}{l}16600 \\
19000 \\
\end{array}$ & $\begin{array}{l}12500 \\
13500 \\
\end{array}$ \\
\hline & $2 A$ & $\begin{array}{l}900 \\
900 \\
\end{array}$ & $\begin{array}{l}48000 \\
49000 \\
\end{array}$ & $\begin{array}{l}66000 \\
66000 \\
\end{array}$ & $\begin{array}{l}23300 \\
22400 \\
\end{array}$ & $\begin{array}{l}12500 \\
12300 \\
\end{array}$ \\
\hline & $2 B$ & $\begin{array}{l}600 \\
600 \\
\end{array}$ & $\begin{array}{l}31000 \\
29000 \\
\end{array}$ & $\begin{array}{l}43000 \\
42000 \\
\end{array}$ & $\begin{array}{l}20400 \\
20400 \\
\end{array}$ & $\begin{array}{l}8300 \\
7800 \\
\end{array}$ \\
\hline & $2 C$ & $\begin{array}{l}700 \\
600 \\
\end{array}$ & $\begin{array}{l}33000 \\
31000 \\
\end{array}$ & $\begin{array}{l}48000 \\
44000 \\
\end{array}$ & $\begin{array}{l}38000 \\
43000 \\
\end{array}$ & $\begin{array}{l}8900 \\
8300 \\
\end{array}$ \\
\hline & $2 D$ & $\begin{array}{l}700 \\
700 \\
\end{array}$ & $\begin{array}{r}35000 \\
35000 \\
\end{array}$ & $\begin{array}{l}51000 \\
51000 \\
\end{array}$ & $\begin{array}{l}54000 \\
56000 \\
\end{array}$ & $\begin{array}{l}9500 \\
9500 \\
\end{array}$ \\
\hline & Comp. & $\begin{array}{r}1200 \\
900\end{array}$ & $\begin{array}{l}64000 \\
41000\end{array}$ & $\begin{array}{l}87000 \\
56000\end{array}$ & $\begin{array}{l}60000 \\
39000\end{array}$ & $\begin{array}{l}16200 \\
11200\end{array}$ \\
\hline
\end{tabular}

Comp.: core composite sample data

DLC: drainable liquid composite 
Table 6. Homogenization Test Data Page 1 of 2

\begin{tabular}{|c|c|c|c|c|c|c|}
\hline \multirow[t]{2}{*}{ Core } & \multirow{2}{*}{$\begin{array}{l}\text { Quarter } \\
\text { Segment }\end{array}$} & \multirow[t]{2}{*}{ Location } & \multicolumn{4}{|c|}{ ICP Acid Digestion $(\mu \mathrm{g} / \mathrm{g})$} \\
\hline & & & Al & $\mathrm{Fe}$ & $\mathrm{Na}$ & $\mathrm{Ni}$ \\
\hline \multirow[t]{4}{*}{34} & \multirow[t]{2}{*}{$2 C$} & 1 & $\begin{array}{l}11920 \\
12234 \\
\end{array}$ & $\begin{array}{r}12426 \\
7064 \\
\end{array}$ & $\begin{array}{l}85165 \\
83680 \\
\end{array}$ & $\begin{array}{l}18605 \\
16773 \\
\end{array}$ \\
\hline & & 2 & $\begin{array}{l}11418 \\
10536\end{array}$ & $\begin{array}{l}9984 \\
6236\end{array}$ & $\begin{array}{l}80119 \\
83402\end{array}$ & $\begin{array}{l}17283 \\
16830\end{array}$ \\
\hline & \multirow[t]{2}{*}{ 2D } & 1 & $\begin{array}{l}34578 \\
22444\end{array}$ & $\begin{array}{l}15055 \\
14867\end{array}$ & $\begin{array}{l}74795 \\
82802\end{array}$ & $\begin{array}{l}14072 \\
15580\end{array}$ \\
\hline & & 2 & $\begin{array}{l}27791 \\
23400\end{array}$ & $\begin{array}{l}30159 \\
15230\end{array}$ & $\begin{array}{l}79291 \\
84930\end{array}$ & $\begin{array}{l}15501 \\
16406\end{array}$ \\
\hline \multirow[t]{2}{*}{35} & \multirow[t]{2}{*}{20} & 1 & $\begin{array}{l}35097 \\
35751 \\
\end{array}$ & $\begin{array}{l}28603 \\
25806 \\
\end{array}$ & $\begin{array}{l}68701 \\
69416\end{array}$ & $\begin{array}{l}11287 \\
10978\end{array}$ \\
\hline & & 2 & $\begin{array}{l}30843 \\
31431 \\
\end{array}$ & $\begin{array}{l}23400 \\
25481 \\
\end{array}$ & $\begin{array}{l}66797 \\
71332 \\
\end{array}$ & $\begin{array}{l}10211 \\
10758 \\
\end{array}$ \\
\hline \multirow[t]{4}{*}{36} & \multirow[t]{2}{*}{$1 C$} & 1 & $\begin{array}{l}10520 \\
10423 \\
\end{array}$ & $\begin{array}{l}24343 \\
19251 \\
\end{array}$ & $\begin{array}{l}74657 \\
75027 \\
\end{array}$ & $\begin{array}{l}18371 \\
18404 \\
\end{array}$ \\
\hline & & 2 & $\begin{array}{l}11613 \\
10401 \\
\end{array}$ & $\begin{array}{l}27043 \\
19227 \\
\end{array}$ & $\begin{array}{l}73045 \\
71706 \\
\end{array}$ & $\begin{array}{l}17505 \\
18540 \\
\end{array}$ \\
\hline & \multirow[t]{2}{*}{20} & 1 & $\begin{array}{l}2782 \\
2826 \\
\end{array}$ & $\begin{array}{l}29671 \\
30210 \\
\end{array}$ & $\begin{array}{l}95604 \\
97629 \\
\end{array}$ & $\begin{array}{l}751 \\
769 \\
\end{array}$ \\
\hline & & 2 & $\begin{array}{l}3307 \\
3667\end{array}$ & $\begin{array}{l}29656 \\
32875 \\
\end{array}$ & $\begin{array}{l}93803 \\
99336 \\
\end{array}$ & $\begin{array}{l}777 \\
854\end{array}$ \\
\hline
\end{tabular}


Table 6. Homogenization Test Data Page 2 of 2

\begin{tabular}{|c|c|c|c|c|c|}
\hline \multirow[t]{2}{*}{ Core } & \multirow{2}{*}{$\begin{array}{l}\text { Quarter } \\
\text { Segment }\end{array}$} & \multirow[t]{2}{*}{ Location } & \multicolumn{3}{|c|}{ ICP Acid Digestion $(\mu \mathrm{g} / \mathrm{g})$} \\
\hline & & & $\mathrm{Pb}$ & $\mathbf{U}$ & $p$ \\
\hline \multirow[t]{4}{*}{34} & \multirow[t]{2}{*}{$2 C$} & 1 & $\begin{array}{l}1321 \\
1140 \\
\end{array}$ & $\begin{array}{l}5978 \\
5796 \\
\end{array}$ & $\begin{array}{l}17980 \\
17803 \\
\end{array}$ \\
\hline & & 2 & $\begin{array}{l}1166 \\
1066 \\
\end{array}$ & $\begin{array}{l}6248 \\
5660 \\
\end{array}$ & $\begin{array}{l}17574 \\
17488 \\
\end{array}$ \\
\hline & \multirow[t]{2}{*}{ 2D } & 1 & $\begin{array}{l}2594 \\
2480 \\
\end{array}$ & $\begin{array}{l}18947 \\
20339 \\
\end{array}$ & $\begin{array}{l}16581 \\
18483 \\
\end{array}$ \\
\hline & & 2 & $\begin{array}{l}3130 \\
2661 \\
\end{array}$ & $\begin{array}{l}20285 \\
22038 \\
\end{array}$ & $\begin{array}{l}18355 \\
19544 \\
\end{array}$ \\
\hline \multirow[t]{2}{*}{35} & \multirow[t]{2}{*}{20} & 1 & $\begin{array}{r}3865 \\
3796 \\
\end{array}$ & $\begin{array}{l}86499 \\
84819 \\
\end{array}$ & $\begin{array}{l}19290 \\
18972 \\
\end{array}$ \\
\hline & & 2 & $\begin{array}{r}3461 \\
3978 \\
\end{array}$ & $\begin{array}{l}77991 \\
81653 \\
\end{array}$ & $\begin{array}{l}17638 \\
18879 \\
\end{array}$ \\
\hline \multirow[t]{4}{*}{36} & \multirow[t]{2}{*}{$1 C$} & 1 & $\begin{array}{l}2196 \\
2168 \\
\end{array}$ & $\begin{array}{r}4519 \\
4498 \\
\end{array}$ & $\begin{array}{l}18505 \\
18561 \\
\end{array}$ \\
\hline & & 2 & $\begin{array}{r}2356 \\
2135 \\
\end{array}$ & $\begin{array}{l}4276 \\
4449 \\
\end{array}$ & $\begin{array}{l}17332 \\
18109 \\
\end{array}$ \\
\hline & \multirow[t]{2}{*}{20} & 1 & $\begin{array}{l}966 \\
963 \\
\end{array}$ & $\begin{array}{l}56633 \\
57462 \\
\end{array}$ & $\begin{array}{l}28234 \\
28989 \\
\end{array}$ \\
\hline & & 2 & $\begin{array}{l}1237 \\
1337 \\
\end{array}$ & $\begin{array}{l}55873 \\
61867 \\
\end{array}$ & $\begin{array}{l}28721 \\
31131 \\
\end{array}$ \\
\hline
\end{tabular}


Table 7. Acid Digestion Inventory Statistics $(\mu \mathrm{g} / \mathrm{g})$

\begin{tabular}{|c|c|c|c|c|c|c|}
\hline \multicolumn{7}{|c|}{ Excluding Drainable Liquid Composites } \\
\hline Analyte & $g$ & BMS & $\partial \frac{2}{x}$ & df & $\mathbf{L}$ & $\mathbf{U}$ \\
\hline Al & $2.45 e+04$ & $7.65 e+08$ & $1.28 e+08$ & 2 & 0.00 & $7.31 e+04$ \\
\hline $\mathrm{Ca}$ & $1.67 \mathrm{e}+04$ & $5.12 e+07$ & $8.53 e+06$ & 2 & $4.18 \mathrm{e}+03$ & $2.93 e+04$ \\
\hline $\mathrm{Fe}$ & $2.19 e+04$ & $2.63 e+07$ & $4.39 \mathrm{e}+06$ & 2 & $1.28 e+04$ & $3.09 \mathrm{e}+04$ \\
\hline $\mathrm{Na}$ & $8.96 \mathrm{e}+04$ & $5.57 e+08$ & $9.28 \mathrm{e}+07$ & 2. & $4.81 e+04$ & $1.31 \mathrm{e}+05$ \\
\hline $\mathrm{Ni}$ & $1.31 e+04$ & $3.20 \mathrm{e}+07$ & $5.33 \mathrm{e}+06$ & 2 & $3.18 \mathrm{e}+03$ & $2.30 \mathrm{e}+04$ \\
\hline $\mathrm{Pb}$ & $2.55 e+03$ & $4.59 \mathrm{e}+06$ & $7.64 e+05$ & 2 & 0.00 & $6.31 e+03$ \\
\hline U & $5.84 e+04$ & $3.22 \mathrm{e}+09$ & $5.37 e+08$ & 2 & 0.00 & $1.58 e+05$ \\
\hline$p$ & $2.29 e+04$ & $9.42 e+07$ & $1.57 \mathrm{e}+07$ & 2 & $5.86 e+03$ & $4.00 \mathrm{e}+04$ \\
\hline \multicolumn{7}{|c|}{ Including Drainable Liquid Composites } \\
\hline Analyte & $\bar{y}$ & BMS & $\partial_{y}^{2}$ & $d f$ & $\mathrm{~L}$ & $\underline{U}$ \\
\hline Al & NA & NA & NA & NA & NA & NA \\
\hline $\mathrm{Ca}$ & $1.02 e+04$ & $1.87 \mathrm{e}+08$ & $1.87 e+07$ & 4 & 0.00 & $2.22 e+04$ \\
\hline $\mathrm{Fe}$ & $1.35 e+04$ & $2.77 e+08$ & $2.77 e+07$ & 4 & 0.00 & $2.81 e+04$ \\
\hline $\mathrm{Na}$ & $8.42 e+04$ & $4.25 e+08$ & $4.25 e+07$ & 4 & $6.61 e+04$ & $1.02 e+05$ \\
\hline $\mathrm{Ni}$ & $8.08 e+03$ & $1.11 \mathrm{e}+08$ & $1.11 \mathrm{e}+07$ & 4 & 0.00 & $1.73 e+04$ \\
\hline $\mathrm{Pb}$ & NA & NA & NA & NA & NA & NA \\
\hline$U$ & $3.54 \mathrm{e}+04$ & $3.59 e+09$ & $3.59 e+08$ & 4 & 0.00 & $8.80 e+04$ \\
\hline$p$ & $1.53 e+04$ & $2.66 \mathrm{e}+08$ & $2.66 e+07$ & 4 & $9.78 \mathrm{e}+02$ & $2.96 \mathrm{e}+04$ \\
\hline
\end{tabular}


Table 8. $\mathrm{KOH} / \mathrm{Ni}$ Fusion Dissolution Inventory Statistics $(\mu \mathrm{g} / \mathrm{g}$ )

\begin{tabular}{|l|c|c|c|r|r|r|}
\hline Analyte & $y$ & BMS & $\partial_{\bar{k}}^{2}$ & \multicolumn{1}{c|}{$\mathrm{df}$} & $\mathrm{L}$ & $U$ \\
\hline $\mathrm{Al}$ & 26540 & $7.53 \mathrm{e}+08$ & $1.51 \mathrm{e}+08$ & 2 & 0 & 79337 \\
\hline $\mathrm{Ca}$ & 19950 & 65570881 & 13114176 & 2 & 4367 & 35533 \\
\hline $\mathrm{Fe}$ & 27915 & 36153926 & 7230785 & 2 & 16344 & 39486 \\
\hline $\mathrm{Na}$ & 103893 & $8.43 \mathrm{e}+08$ & $1.69 \mathrm{e}+08$ & 2 & 48026 & 159760 \\
\hline $\mathrm{Ni}$ & $\mathrm{NA}$ & $\mathrm{NA}$ & $\mathrm{NA}$ & $\mathrm{NA}$ & $\mathrm{NA}$ & $\mathrm{NA}$ \\
\hline $\mathrm{Pb}$ & 2937 & 6508141 & 1301628 & 2 & 0 & 7846 \\
\hline $\mathrm{U}$ & 80730 & $2.87 \mathrm{e}+09$ & $5.74 \mathrm{e}+08$ & 2 & 0 & 183779 \\
\hline $\mathrm{P}$ & 27971 & $1.29 \mathrm{e}+08$ & 25753724 & 2 & 6135 & 49808 \\
\hline
\end{tabular}


Table 9. Water Leach Inventory Statistics $(\mu \mathrm{g} / \mathrm{g})$

\begin{tabular}{|c|c|c|c|c|c|c|}
\hline \multicolumn{7}{|c|}{ Excluding Drainable Liquid Composites } \\
\hline Analyte & 9 & BMS & $\partial_{\frac{x}{2}}^{2}$ & $d f$ & $\mathbf{L}$ & u \\
\hline A! & $5.21 e+02$ & $1.43 e+05$ & $2.87 e+04$ & 2 & 0.00 & $1.25 e+03$ \\
\hline $\mathrm{Ca}$ & $3.38 e+02$ & $7.04 e+03$ & $1.41 \mathrm{e} \cdot 03$ & 2 & $1.76 \mathrm{e}+02$ & $4.99 e+02$ \\
\hline le & $1.17 e+03$ & $3.66 \mathrm{e}+05$ & $7.31 e+04$ & 2 & $4.87 e+00$ & $2.33 e+03$ \\
\hline $\mathrm{Na}$ & $8.85 e+04$ & $1.31 e+09$ & $2.62 e+08$ & 2 & $1.88 \mathrm{e}+04$ & i. $58 \mathrm{e}+05$ \\
\hline $\mathrm{Ni}$ & $6.79 e+02$ & $1.38 e+05$ & $2.76 e+04$ & 2 & 0.00 & $1.39 \mathrm{e}+03$ \\
\hline $\mathrm{Pb}$ & NA & NA & NA & NA & NA & NA \\
\hline$U$ & $2.17 e+03$ & $9.87 e+06$ & $1.97 e+06$ & 2 & 0.00 & $8.21 e+03$ \\
\hline$p$ & $1.01 e+04$ & $6.72 e+07$ & $1.34 e+07$ & 2 & 0.00 & $2.59 e+04$ \\
\hline \multicolumn{7}{|c|}{ Including Drainable Liquid Composites } \\
\hline Analyte & $\bar{y}$ & BMS & $\partial_{x}^{2}$ & df & $\mathrm{L}$ & U \\
\hline Ai & NA & NA & NA & NA & NA & NA \\
\hline $\mathrm{Ca}$ & $2.53 e+02$ & $4.68 e+04$ & $6.69 e+03$ & 3 & 0.00 & $5.13 e+02$ \\
\hline $\mathrm{Fe}$ & $1.09 e+03$ & $2.42 e+05$ & $2.69 e+04$ & 4 & $6.37 e+02$ & $1.55 e+03$ \\
\hline $\mathrm{Na}$ & $8.41 \mathrm{e}+04$ & $7.63 e+08$ & $8.48 e+07$ & 4 & $5.85 e+04$ & $1.10 \mathrm{e}+05$ \\
\hline $\mathrm{Ni}$ & $6.62 e+02$ & $9.20 \mathrm{e}+04$ & $1.02 e+04$ & 4 & $3.81 e+02$ & $9.43 e+02$ \\
\hline $\mathrm{Pb}$ & NA & NA & NA & NA & NA & NA \\
\hline U & $1.67 \mathrm{e}+03$ & $5.62 e+06$ & $6.25 e+05$ & 4 & 0.00 & $3.87 e+03$ \\
\hline$P$ & $7.35 e+03$ & $5.50 e+07$ & $6.11 \mathrm{e}+06$ & 4 & $4.86 e+02$ & $1.42 e+04$ \\
\hline
\end{tabular}


Table 10. Radio Chemistry Statistics ( $\mu \mathrm{Ci} / \mathrm{g})$

\begin{tabular}{|c|c|c|c|c|c|c|}
\hline Element & $y$ & BMS & $\partial_{x}^{2}$ & df & "L & $U$ \\
\hline Cs -137 & 747 & 8380.7 & 1676.14 & 2 & 571 & 924 \\
\hline$S r-90$ & 2189 & 4742404 & 948480.5 & 2 & 0 & 6380 \\
\hline U & 68.6 & 3886.215 & 1295.405 & 1 & 0.0 & 223.5 \\
\hline $\mathrm{Pu}-239 / 240$ & 0.06 & 0.013323 & 0.002665 & 2 & 0.0 & 0.28 \\
\hline $\mathrm{Pu}-238$ & 0.06 & 0.025023 & 0.005005 & 2 & 0.00 & 0.37 \\
\hline
\end{tabular}

Table 11. Ion Chromatography Anion Statistics $(\mu \mathrm{g} / \mathrm{g})$

\begin{tabular}{|l|r|r|r|r|r|r|}
\hline Analyte & \multicolumn{1}{|c|}{$\bar{y}$} & \multicolumn{1}{c|}{ BMS } & \multicolumn{1}{c|}{$\partial_{\bar{x}}^{2}$} & \multicolumn{1}{c|}{ df } & \multicolumn{1}{c|}{ L } & \multicolumn{1}{c|}{ U } \\
\hline $\mathrm{Cl}$ & 980 & 109000 & 21800 & 2 & 345 & 1615 \\
\hline $\mathrm{NO}_{2}$ & 47200 & $2.99 \mathrm{e}+08$ & 59780000 & 2 & 13930 & 80470 \\
\hline $\mathrm{NO}_{3}$ & 62000 & $5.95 \mathrm{e}+08$ & $1.19 \mathrm{e}+08$ & 2 & 15080 & 108921 \\
\hline $\mathrm{PO}_{4}$ & 30760 & $5.86 \mathrm{e}+08$ & $1.17 \mathrm{e}+08$ & 2 & 0 & 77337 \\
\hline $\mathrm{SO}_{4}$ & 124040 & 20926000 & 4185200 & 2 & 115237 & 132843 \\
\hline
\end{tabular}


Table 12. Homogenization Test Results

\begin{tabular}{|l|c|c|c|c|}
\hline \multirow{2}{*}{ Analyte } & \multirow{2}{*}{$\begin{array}{c}\text { Test: } \sigma_{L}^{2}=0 \\
p-v a l u e\end{array}$} & \multicolumn{3}{|c|}{$x$ Variability due to: } \\
\cline { 3 - 5 } & & segment & homogenization & añalytical \\
\hline $\mathrm{Al}$ & 0.65 & 94.82 & 0.00 & 5.18 \\
$\mathrm{Ca}$ & 0.10 & 99.45 & 0.34 & 0.21 \\
$\mathrm{Fe}$ & 0.58 & 77.10 & 0.00 & 22.90 \\
$\mathrm{Na}$ & 0.72 & 92.95 & 0.00 & 7.05 \\
$\mathrm{Ni}$ & 0.42 & 99.17 & 0.04 & 0.79 \\
$\mathrm{P}$ & 0.26 & 96.55 & 0.74 & 2.71 \\
$\mathrm{~Pb}$ & 0.22 & 99.73 & 0.87 & 2.40 \\
$\mathrm{U}$ & 0.08 & 99.55 & 0.21 & 0.24 \\
\hline
\end{tabular}


12100-PLT93-020

ATTACHMENT 4

Page 1 of 2

Table 13. Segment versus Composite Statistics for Core 34

\begin{tabular}{|c|c|c|c|c|c|c|}
\hline \multirow[t]{2}{*}{ Analyte } & \multirow[t]{2}{*}{$\bar{y}_{w}$} & \multirow[t]{2}{*}{$\partial^{2}\left(\bar{y}_{H}\right)$} & \multirow[t]{2}{*}{ composite } & \multirow[t]{2}{*}{$d f *$} & \multicolumn{2}{|c|}{$95 \%$ C. I. for the SCC } \\
\hline & & & & & $a$ & u \\
\hline Al & 23549 & 52434015 & 29798 & 2 & 0 & 54708 \\
\hline $\mathrm{Ca}$ & 25894 & 18916814 & 28984 & 8 & 15864 & 35923 \\
\hline $\mathrm{Fe}$ & 13295 & 19518529 & 22848 & 8 & 3107 & 23483 \\
\hline $\mathrm{Na} \mathrm{\#}$ & 87128 & 13536665 & 114891 & 9 & 78806 & 95451 \\
\hline $\mathrm{Pb}$ & 3220 & 1101497 & 3326 & 3 & 0 & 6559 \\
\hline$\underline{U}$ & 20098 & $6.98 \mathrm{e}+08$ & 14369 & 5 & 0 & 88039 \\
\hline 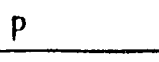 & 17318 & 6507390 & 21956 & 6 & 11076 & 23561 \\
\hline $\mathrm{Cl} \#$ & 963 & 4464 & 1300 & 6 & 799 & 1126 \\
\hline $\mathrm{NO}_{2}$ & 51875 & 18756838 & 62000 & 5 & 40740 & 63010 \\
\hline $\mathrm{NO}_{3}$ & 68125 & 27969779 & 80000 & 5 & 54528 & 81722 \\
\hline $\mathrm{PO}_{4}$ & 13200 & 33665294 & 19100 & 7 & 0 & 26922 \\
\hline $\mathrm{SO}_{4} *$ & 12587 & 856924 & 15600 & 6 & 10322 & 14852 \\
\hline Cs- 137 & 539 & 17666 & 750 & 9 & 238 & 840 \\
\hline$S r-90$ & 2456 & 536927 & 3510 & 4 & 422 & 4490 \\
\hline
\end{tabular}

" significant difference between segment data and composite

units: $\quad \mu \mathrm{g} / \mathrm{g}: \quad \mathrm{Al}, \mathrm{Ca}, \mathrm{Fe}, \mathrm{Na}, \mathrm{Pb}, \mathrm{U}, \mathrm{P}, \mathrm{Cl}, \mathrm{NO}_{2}, \mathrm{NO}_{3}, \mathrm{PO}_{4}, \mathrm{SO}_{4}$

$\mu \mathrm{Ci} / \mathrm{g}: \quad \mathrm{Cs}-137, \mathrm{Sr}-90$ 
Table 14. Segment versus Composite Statistics for Core 36

\begin{tabular}{|c|c|c|c|c|c|c|}
\hline \multirow[t]{2}{*}{ Analyte } & \multirow[t]{2}{*}{$\bar{y}_{w}$} & \multirow[t]{2}{*}{$\bar{y}_{c}$} & \multirow[t]{2}{*}{$\partial^{2}\left(\bar{y}_{w}-\bar{y}_{c}\right)$} & \multirow[t]{2}{*}{$d f *$} & \multicolumn{2}{|c|}{ 95\% C. 1. for difference } \\
\hline & & & & & L & U \\
\hline Al & 4948 & 6410 & $4.29 e+08$ & 3 & -67364 & 64439 \\
\hline $\mathrm{Ca}$ & 15484 & 20391 & 51702254 & 5 & -23393 & 13580 \\
\hline $\mathrm{Fe}$ & 18355 & 26012 & 37595492 & 7 & -22158 & 6844 \\
\hline $\mathrm{Na}$ & 92724 & 120730 & $4.35 e+08$ & 2 & -117756 & 61744 \\
\hline $\mathrm{Pb}$ & 1788 & 1049 & 4355567 & 3 & -5902 & 7379 \\
\hline$U$ & 96380 & 104910 & $2.13 e+09$ & 4 & -136748 & 119688 \\
\hline$P$ & 24733 & 36761 & 71007390 & 2 & -48288 & 24232 \\
\hline $\mathrm{Cl}$ & 783 & 1050 & 58964 & 2 & -1312 & 778 \\
\hline $\mathrm{NO}_{2}$ & 40750 & 52500 & $1.68 e+08$ & 3 & -53025 & 29525 \\
\hline $\mathrm{NO}_{3}$ & 55667 & 71500 & $3.25 e+08$ & 2 & -93463 & 61796 \\
\hline $\mathrm{PO}_{4}$ & 28858 & 49500 & $3.27 e+08$ & 2 & -98414 & 57130 \\
\hline $\mathrm{SO}_{2}$ & 10600 & .13700 & 11319924 & 2 & -17578 & 11377 \\
\hline$C_{S}-137$ & 559 & 793 & 21857 & 11 & -559 & 92 \\
\hline Sr-90 & 384 & 508 & 2908128 & 3 & -7462 & 7214 \\
\hline
\end{tabular}

units: $\quad \mu \mathrm{g} / \mathrm{g}: \quad \mathrm{Al}, \mathrm{Ca}, \mathrm{Fe}, \mathrm{Na}, \mathrm{Pb}, \mathrm{U}, \mathrm{P}, \mathrm{Cl}, \mathrm{MO}_{2}, \mathrm{NO}_{3}, \mathrm{PO}_{4}, \mathrm{SO}_{4}$

$\mu \mathrm{Ci} / \mathrm{g}: \quad \mathrm{Cs}-137, \mathrm{Sr}-90$ 
Table 15. Acid Digestion Spatial and Analytical Error Estimates

\begin{tabular}{|c|c|c|c|c|c|c|}
\hline \multicolumn{7}{|c|}{ Excluding Drainable Liquid Composites } \\
\hline \multirow[t]{2}{*}{ Analyte } & \multirow[t]{2}{*}{$\partial_{2}^{2}$} & \multirow[t]{2}{*}{$\delta_{0}^{2}$} & \multicolumn{2}{|c|}{ 95\% C. 1. for $\sigma_{2}^{2} \star$} & \multicolumn{2}{|c|}{$95 \%$ C. I. for $\sigma^{2}$} \\
\hline & & & $L$ & U & $L$ & $U$ \\
\hline Al & $3.67 e+08$ & $3.10 e+07$ & $7.85 e+07$ & $7.44 e+09$ & $9.9 .3 e+06$ & $4.30 \mathrm{e}+08$ \\
\hline $\mathrm{Ca}$ & $2.49 \mathrm{e}+07$ & $1.44 \mathrm{e}+06$ & $6.26 e+06$ & $4.98 \mathrm{e}+08$ & $4.62 \mathrm{e}+05$ & $2.00 e+07$ \\
\hline $\mathrm{Fe}$ & 0.00 & $2.76 e+07$ & 0.00 & $2.43 e+08$ & $8.85 e+06$ & $3.83 e+08$ \\
\hline $\mathrm{Na}$ & $2.66 \mathrm{e}+08$ & $2.39 e+07$ & $5.50 e+07$ & $5.42 e+09$ & $7.66 \mathrm{e}+06$ & $3.32 e+08$ \\
\hline $\mathrm{Ni}$ & $1.55 e+07$ & $1.06 \mathrm{e}+06$ & $3.65 \mathrm{e}+06$ & $3.11 e+08$ & $3.41 e+05$ & $1.48 e+07$ \\
\hline $\mathrm{Pb}$ & $2.28 \mathrm{e}+06$ & $2.41 e+04$ & $7.28 \mathrm{e}+05$ & $4.47 e+07$ & $7.74 \mathrm{e}+03$ & $3.35 \mathrm{e}+05$ \\
\hline U & $1.56 \mathrm{e}+09$ & $1.10 \mathrm{e}+08$ & $3.63 \mathrm{e}+08$ & $3.14 \mathrm{e}+10$ & $3.54 e+07$ & $1.53 \mathrm{e}+09$ \\
\hline$p$ & $4.52 e+07$ & $3.83 e+06$ & $9.64 \mathrm{e}+06$ & $9.17 e+08$ & $1.23 e+06$ & $5.32 e+07$ \\
\hline \multicolumn{7}{|c|}{ Including Drainable Liquid Composites } \\
\hline \multirow[t]{2}{*}{ Analyte } & \multirow[t]{2}{*}{$\partial_{8}^{2}$} & \multirow[t]{2}{*}{$\partial_{0}^{2}$} & \multicolumn{2}{|c|}{ 95\% C. I. for $\sigma_{s}^{2} \star$} & \multicolumn{2}{|c|}{$95 \%$ C. I. for $\sigma^{2}$} \\
\hline & & & $\mathrm{L}$ & U & $L$ & U \\
\hline Al & NA & NA & $N A$ & NA & NA & NA \\
\hline $\mathrm{Ca}$ & $9.29 e+07$ & $8.64 e+05$ & $3.84 e+07$ & $5.25 e+08$ & $3.37 e+05$ & $5.20 e+06$ \\
\hline $\mathrm{Fe}$ & $1.30 e+08$ & $1.65 e+07$ & $4.02 e+07$ & $7.71 \mathrm{e}+08$ & $6.45 e+06$ & $9.97 e+07$ \\
\hline $\mathrm{Na}$ & $2.05 \mathrm{e}+08$ & $1.44 \mathrm{e}+07$ & $7.39 \mathrm{e}+07$ & $1.19 \mathrm{e}+09$ & $5.61 \mathrm{e}+06$ & $8.67 e+07$ \\
\hline $\mathrm{Ni}$ & $5.51 e+07$ & $6.38 e+05$ & $2.27 e+07$ & $3.12 e+08$ & $2.48 e+05$ & $3.84 e+06$ \\
\hline $\mathrm{Pb}$ & NA & NA & NA & NA & NA & NA \\
\hline U & $1.76 e+09$ & $6.61 \mathrm{e}+07$ & $6.84 e+08$ & $1.01 e+10$ & $2.58 \mathrm{e}+07$ & $3.98 e+08$ \\
\hline$p$ & $1.32 e+08$ & $2.30 \mathrm{e}+06$ & $5.35 e+07$ & $7.47 e+08$ & $8.96 \mathrm{e}+05$ & $1.39 \mathrm{e}+07$ \\
\hline
\end{tabular}


Table 16. Water Leach Spatial and Analytical Error Estimates

\begin{tabular}{|c|c|c|c|c|c|c|}
\hline \multicolumn{7}{|c|}{ Excluding Drainable Liquid Composites } \\
\hline \multirow[t]{2}{*}{ Analyte } & \multirow[t]{2}{*}{$\partial_{s}^{2}$} & \multirow{2}{*}{$\hat{\sigma}^{2}$} & \multicolumn{2}{|c|}{ 95\% C. 1. for $\sigma^{2} *$} & \multicolumn{2}{|c|}{$95 \%$ C. I. for $\sigma^{2}$} \\
\hline & & & $\mathbf{L}$ & U & $\mathrm{L}$ & U \\
\hline Al & $7.06 \mathrm{e}+04$ & $3.05 e+04$ & 0.00 & $1.73 e+06$ & $8.25 e+03$ & $1.20 \mathrm{e}+05$ \\
\hline $\mathrm{Ca}$ & 0.00 & $3.78 e+04$ & 0.00 & $6.16 e+04$ & $1.02 e+04$ & $1.50 \mathrm{e}+05$ \\
\hline $\mathrm{Fe}$ & $2.26 e+05$ & $3.43 e+03$ & $6.28 e+04$ & $4.45 e+06$ & $9.30 e+02$ & $1.36 \mathrm{e}+04$ \\
\hline $\mathrm{Na}$ & $5.01 e+08$ & $5.11 e+08$ & 0.00 & $1.57 e+10$ & $1.38 \mathrm{e}+08$ & $2.02 e+09$ \\
\hline $\mathrm{Ni}$ & $8.56 e+04$ & $1.29 e+03$ & $2.38 e+04$ & $1.68 \mathrm{e}+06$ & $3.49 e+02$ & $5.09 e+03$ \\
\hline $\mathrm{Pb}$ & NA & NA & NA & NA & NA & NA \\
\hline$\underline{U}$ & $4.55 e+06$ & $2.60 \mathrm{e}+06$ & 0.00 & $1.19 e+08$ & $7.03 e+05$ & $1.03 e+07$ \\
\hline $\mathbf{p}$ & $3.50 \mathrm{e}+07$ & $1.13 e+07$ & 0.00 & $8.12 e+08$ & $3.06 \mathrm{e}+06$ & $4.46 \mathrm{e}+07$ \\
\hline \multicolumn{7}{|c|}{ Including Drainable Liquid Composites } \\
\hline \multirow[t]{2}{*}{ Analyte } & \multirow[t]{2}{*}{$\partial_{s}^{2}$} & \multirow[t]{2}{*}{$\partial^{2}$} & \multicolumn{2}{|c|}{ 95\% C. 1. for $\sigma^{2} *$} & \multicolumn{2}{|c|}{$95 \%$ C. I. for $\sigma_{2}^{2}$} \\
\hline & & & $\mathbf{L}$ & U & $\mathbf{L}$ & u \\
\hline Al & NA & NA & NA & NA & NA & NA \\
\hline $\mathrm{Ca}$ & $1.26 e+04$ & $2.52 e+04$ & 0.00 & $2.19 e+05$ & $8.09 e+03$ & $3.44 e+05$ \\
\hline $\mathrm{Fe}$ & $1.35 \mathrm{e}+05$ & $1.74 e+03$ & $5.48 e+04$ & $7.66 e+05$ & $6.26 \mathrm{e}+02$ & $1.45 \mathrm{e}+04$ \\
\hline $\mathrm{Na}$ & $2.86 e+08$ & $2.56 e+08$ & 0.00 & $2.29 e+09$ & $9.18 e+07$ & $2.13 e+09$ \\
\hline $\mathrm{Ni}$ & $5.14 e+04$ & $6.53 e+02$ & $2.08 \mathrm{e}+04$ & $2.91 \mathrm{e}+05$ & $2.34 \mathrm{e}+02$ & $5.44 e+03$ \\
\hline $\mathrm{Pb}$ & NA & MA & NA & NA & NA & NA \\
\hline$\underline{U}$ & $2.43 e+06$ & $1.30 \mathrm{e}+06$ & 0.00 & $1.72 e+07$ & $4.66 \mathrm{e}+05$ & $1.08 e+07$ \\
\hline$p$ & $2.78 e+07$ & $5.64 e+06$ & $4.51 e+06$ & $1.71 e+08$ & $2.03 e+06$ & $4.70 \mathrm{e}+07$ \\
\hline
\end{tabular}


Table 17. KOH/Ni Fusion Dissolution Spatial and Analytical Error Estimates

\begin{tabular}{|c|c|c|c|c|c|c|}
\hline \multirow[t]{2}{*}{ Analyte } & \multirow[t]{2}{*}{$\partial_{8}^{2}$} & \multirow[t]{2}{*}{$\theta^{2}$} & \multicolumn{2}{|c|}{ 95\% C. I. for $\theta_{2}^{2} \star$} & \multicolumn{2}{|c|}{ 95\% C. I. for $\partial^{2}$} \\
\hline & & & $L$ & $u$ & L & 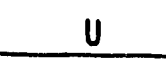 \\
\hline Al & $4.70 \mathrm{e}+08$ & 566681 & $1.55 e+08$ & $9.17 \mathrm{e}+09$ & 153572 & 22398455 \\
\hline $\mathrm{Ca}$ & 40884317 & 155973 & 13086831 & $7.99 e+08$ & 42269 & 6164933 \\
\hline $\mathrm{Fe}$ & 16463951 & 9811603 & 0.00 & $4.34 e+08$ & 2658971 & $3.88 e+08$ \\
\hline $\mathrm{Na}$ & $5.24 e+08$ & 3961112 & $1.60 e+08$ & $1.03 e+10$ & 1073472 & $1.57 \mathrm{e}+08$ \\
\hline $\mathrm{Ni}$ & NA & NA & NA & NA & NA & NA \\
\hline $\mathrm{Pb}$ & 3975509 & 147327 & 775277 & $7.92 e+07$ & 39926 & 5823204 \\
\hline U & $1.78 \mathrm{e}+09$ & 16386526 & $5.34 e+08$ & $3.49 e+10$ & 4440793 & $6.48 \mathrm{e}+08$ \\
\hline$P$ & 80394573 & 137305 & 26371200 & $1.57 e+09$ & 37210 & 5427091 \\
\hline
\end{tabular}

Table 18. Radio Chemistry Spatial and Analytical Error Estimates

\begin{tabular}{|c|c|c|c|c|c|c|}
\hline \multirow[t]{2}{*}{ Analyte } & \multirow[t]{2}{*}{$\hat{\sigma}_{s}^{2}$} & \multirow[t]{2}{*}{$\theta^{2}$} & \multicolumn{2}{|c|}{$95 \%$ C. I. for $\partial^{2} \star$} & \multicolumn{2}{|c|}{ 95\% C. I. for $\hat{\sigma}^{2}$} \\
\hline & & & $\mathbf{L}$ & U & $\mathrm{L}$ & U \\
\hline $\operatorname{Cs}(137)$ & 4949 & 463 & 0 & 101843 & 125 & 18281 \\
\hline$S r-90$ & 3555783 & 1360 & 985902 & 57797174 & 369 & 53767 \\
\hline$\underline{U}$ & & 27573096 & & & 7472384 & $1.09 e+09$ \\
\hline $\mathrm{Pu}-239 / 240$ & 0.008293 & 0.000054 & $2.57 e-03$ & $1.62 e-01$ & 0.000015 & 0.00213 \\
\hline $\mathrm{Pu}-238$ & 0.015619 & 0.000032 & $5.10 e-03$ & $3.05 e-01$ & 0.000009 & 0.001265 \\
\hline
\end{tabular}


Table 19. Ion Chromatography Anion Spatial and Analytical Error Estimates

\begin{tabular}{|c|c|c|c|c|c|c|}
\hline \multirow[t]{2}{*}{ Analyte } & \multirow[t]{2}{*}{$\theta_{s}^{2}$} & \multirow[t]{2}{*}{$\theta^{2}$} & \multicolumn{2}{|c|}{ 95\% C. I. for $\partial^{2} \star$} & \multicolumn{2}{|c|}{$95 \times$ c. I. for $\partial_{2}^{2}$} \\
\hline & & & $L$ & $\underline{U}$ & $L$ & $u$ \\
\hline $\mathrm{Cl}$ & 52500 & 25000 & 0 & 1312401 & 6775 & 988142 \\
\hline $\mathrm{NO}_{2}$ & $1.04 e+08$ & $1.33 e+08$ & 0 & $3.56 \mathrm{e}+09$ & 35907859 & $5.24 e+09$ \\
\hline $\mathrm{NO}_{3}$ & $2.21 e+08$ & $2.41 e+08$ & 0 & $7.09 e+09$ & 65176152 & $9.51 e+09$ \\
\hline $\mathrm{PO}_{3}$ & $2.97 e+08$ & $1.10 \mathrm{e}+08$ & 0 & $7.07 e+09$ & 29894986 & $4.36 \mathrm{e}+09$ \\
\hline $\mathrm{SO}_{\text {, }}$ & 9172500 & 6250000 & 0 & $2.51 e+08$ & 1693767 & $2.47 e+08$ \\
\hline
\end{tabular}




\section{APPENDIX}

This appendix contains the derivations of $\partial^{2}\left(\bar{y}_{y}\right)$ and $\hat{\sigma}^{2}\left(\bar{y}_{w}-\bar{y}_{c}\right)$. For the formulas in this appendix we define the following equalities: $\bar{y}_{W}=\bar{y}_{W i}$ and $\bar{F}_{c}^{W}=\bar{y}_{i}$.

Three statistical models are used in the calculation of these two variance estimates. The first model, for the core and quarter segment data is

$$
y_{i j k}=\mu+c_{i}+s_{i j}+e_{i j k} .
$$

The mean of the two aliquots from the $j^{\text {th }}$ quarter segment of the $i^{\text {th }}$ core is $\bar{y}_{i j}$. A statistical model for this mean is

$$
\bar{y}_{i j .}=\mu+c_{1}+E_{1 j}
$$

where

$\bar{y}_{i j}$. - mean of the two aliquots from the $j^{\text {th }}$ quarter segment of the $i^{\text {th }}$ core,

$\mu=$ overall mean of all the data,

$c_{i}=$ the effect of the $i^{\text {th }}$ core,

$E_{i j}=s_{i j}+\bar{e}_{i j .}$,

$s_{i j}=$ the effect of the $j^{\text {th }}$ quarter segment in the $i^{\text {th }}$ core, and

$\mathbf{e}_{i j}$. = the residual of the $j^{\text {th }}$ quarter segment mean in the $i^{\text {th }}$ core.

The subscripts $i, j$, and $k$ have the following ranges: $i=1, \ldots, a$ (a)number of cores or core composites), $j=1, \ldots, b,\left(b_{i}=\right.$ number of quarter segments in the $f^{\text {th }}$ core $), k=1, \ldots, n$

( $n=$ number of aliquots taken from each quarter segment).

The third model, for core composite sample data is

$$
y_{i k}^{\prime}=\mu^{\prime}+c_{i}^{\prime}+e_{i k}^{\prime}
$$

where

$$
\begin{aligned}
& y_{i k}^{\prime}=k^{\text {th }} \text { aliquot of the } i^{\text {th }} \text { core composite, } \\
& \mu^{\prime}=\text { the overall mean of the all core composite aliquots, } \\
& c_{i}^{\prime}=i^{\text {th }} \text { core composite effect, and } \\
& e_{i k}^{\prime}=k^{\text {th }} \text { residual of the } i^{\text {th }} \text { core composite. }
\end{aligned}
$$

The subscript ranges are the same as those used for the previous model. 
The variance of $\bar{y}_{i j}$. is

$$
\begin{aligned}
V\left(\bar{y}_{1 j .}\right) & =V\left(\mu+c_{1}+E_{1 j}\right) \\
& =\frac{\sigma^{2}}{n}+\sigma_{s}^{2}+\sigma_{c}^{2}
\end{aligned}
$$

where $\sigma_{c}^{2}$ is the variance between cores, $\sigma_{s}^{2}$ is the variance between quarter segments and $\sigma^{2}$ is the analytical error.

A weighted mean representing the simulated core composite (SCC) is

$$
\bar{y}_{w i}=\sum_{j=1}^{b_{i}} w_{j} \bar{y}_{i j .} .
$$

The variance of $\bar{y}_{w i}$ is

$$
\begin{aligned}
V\left(\bar{y}_{w i}\right) & =v\left(\sum_{j=1}^{b_{j}} w_{j} \bar{y}_{i j} \cdot=\sum_{j=1}^{b_{j}} w_{j}^{2} v\left(\bar{y}_{i j} \cdot\right)\right. \\
& =\sum_{j=1}^{b_{j}} w_{j}^{2}\left(\frac{\sigma^{2}}{n}+\sigma_{i}^{2}+\sigma_{c}^{2}\right) .
\end{aligned}
$$

The between mean squares (BMS) from model (2) has expectation

$$
E(B M S)=\frac{\sigma^{2}}{n}+\sigma_{s}^{2}+b_{0} \sigma_{c}^{2}
$$

where

$$
b_{0}=\frac{\sum_{i=1}^{\infty} b_{i}-\frac{\sum_{i=1}^{\infty} b_{i}^{2}}{\sum_{i=1}^{\dot{a}} b_{i}}}{a-1} .
$$

The within mean squares (WMS) from model (2) has the expectation 


$$
E(\text { WMS })=\frac{\sigma^{2}}{n}+\sigma_{s}^{2}
$$

By solving a system of two equations with two unknowns, we obtain .

$$
\begin{aligned}
\partial_{c}^{2} & =\frac{B M S-W M S}{b_{0}}, \\
\frac{\hat{\sigma}^{2}}{n}+\partial_{s}^{2} & =\text { WMS }
\end{aligned}
$$

as estimates of $\sigma_{c}^{2}$ and $\left(\sigma^{2} / n+\sigma_{s}^{2}\right)$ respectively.

From the results above we can obtain an estimate of $\sigma^{2}\left(\bar{y}_{M i}\right)$ which is

$$
\begin{aligned}
\partial^{2}\left(\bar{y}_{w 1}\right) & =P\left(\bar{y}_{w i}\right) \\
& =\sum_{j=1}^{b_{i}} w_{j}^{2}\left(\frac{\partial^{2}}{n}+\partial_{s}^{2}+\partial_{c}^{2}\right) \\
& =\sum_{j=1}^{b_{i}} w_{j}^{2}\left\{W M S+\frac{B M S-W M S}{b_{0}}\right) \\
& =\sum_{j=1}^{b_{i}} w_{j}^{2}\left\{\frac{B M S+\left(b_{0}-1\right) W M S}{b_{0}}\right) .
\end{aligned}
$$

The variance for $q_{i}$, using the structure from model (3), is

$$
V\left(\bar{y}_{i}^{\prime}\right)=\frac{\sigma^{2^{\prime}}+n \sigma_{c}^{2^{\prime}}}{n}
$$

where $\sigma^{21}$ is the analytical error and $\sigma_{c}^{21}$ is the variability between cores. The between mean squares (BMS') expectation for model (3) is

$$
E\left(B M S^{\prime}\right)=\sigma^{2^{\prime}}+n \sigma_{c}^{2^{\prime}} \text {. }
$$

Using this expectation, an estimate of the variance for $y_{i}$. is

$$
\hat{v}\left(\bar{y}_{i}^{\prime}\right)=\frac{B_{M S}^{\prime}}{n} \text {. }
$$


The estimated variance of $\bar{y}_{W 1}-\bar{y}_{i}$. is

$$
\begin{aligned}
\hat{\partial}^{2}\left(\bar{y}_{W i}-\bar{y}_{i .}^{\prime}\right) & =\hat{\sigma}^{2}\left(\bar{y}_{W 1}\right)+\hat{\sigma}^{2}\left(\bar{y}_{i .}\right) \\
& =\left[\sum_{i=1}^{b_{i}} w_{j}^{2}\left[\frac{B M S+\left(b_{0}-1\right) W M S}{b_{0}}\right]\right]+\left[\frac{B M S^{\prime}}{n}\right] .
\end{aligned}
$$

We have assumed that the covariance between the two means is zero. 
12100-PLT93-020

ATTACHMENT 7

PAGE 1 OF 6
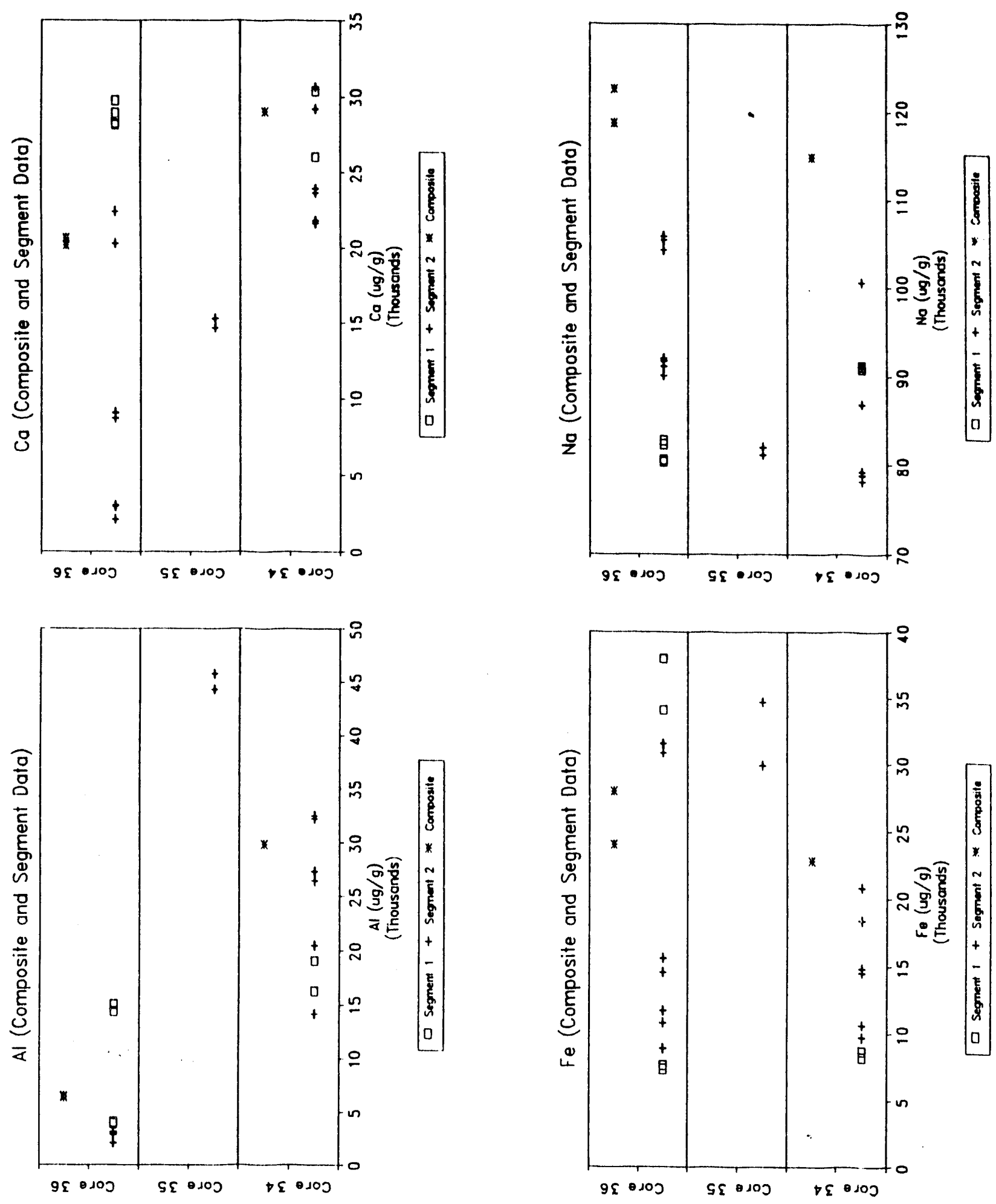

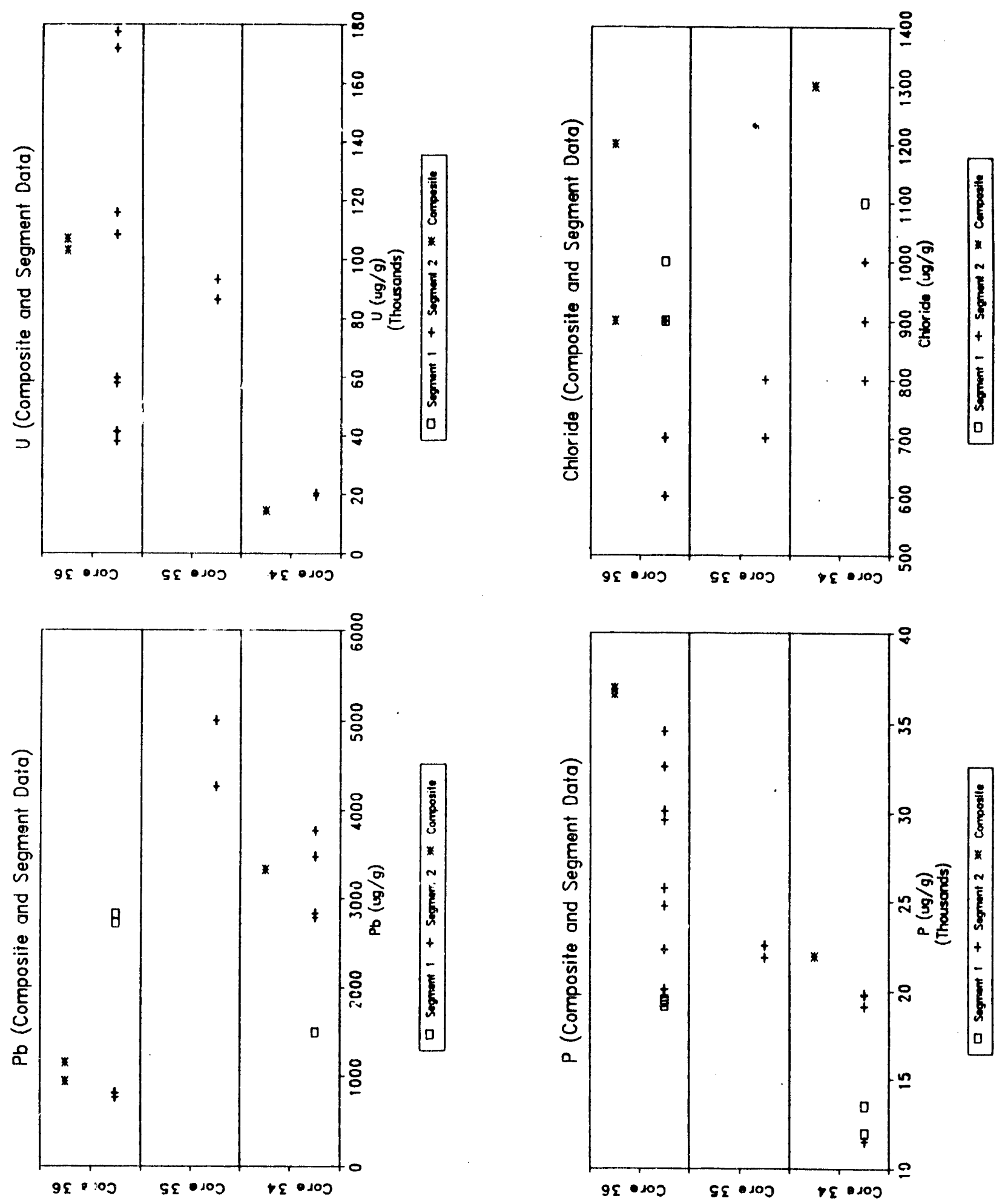

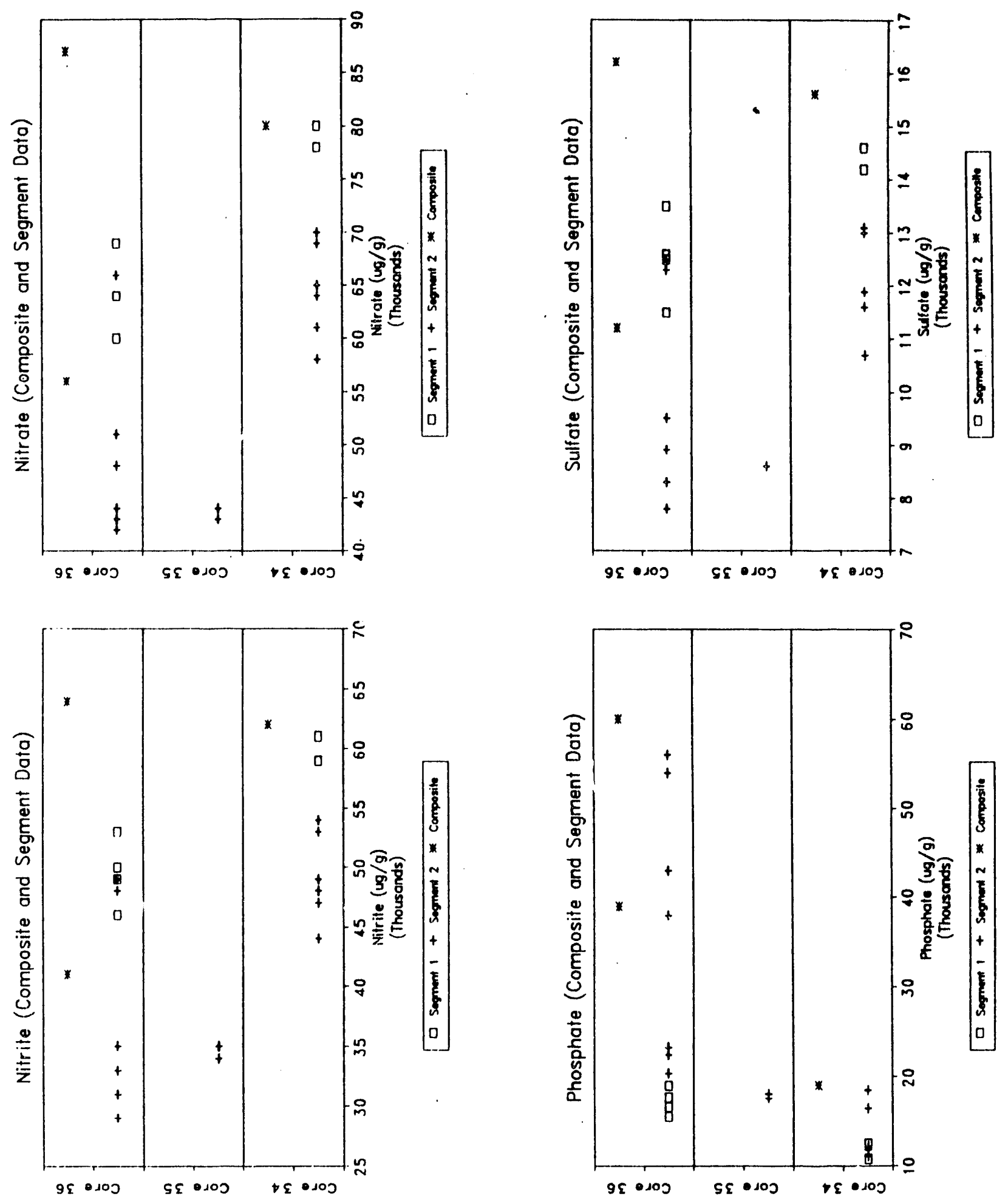

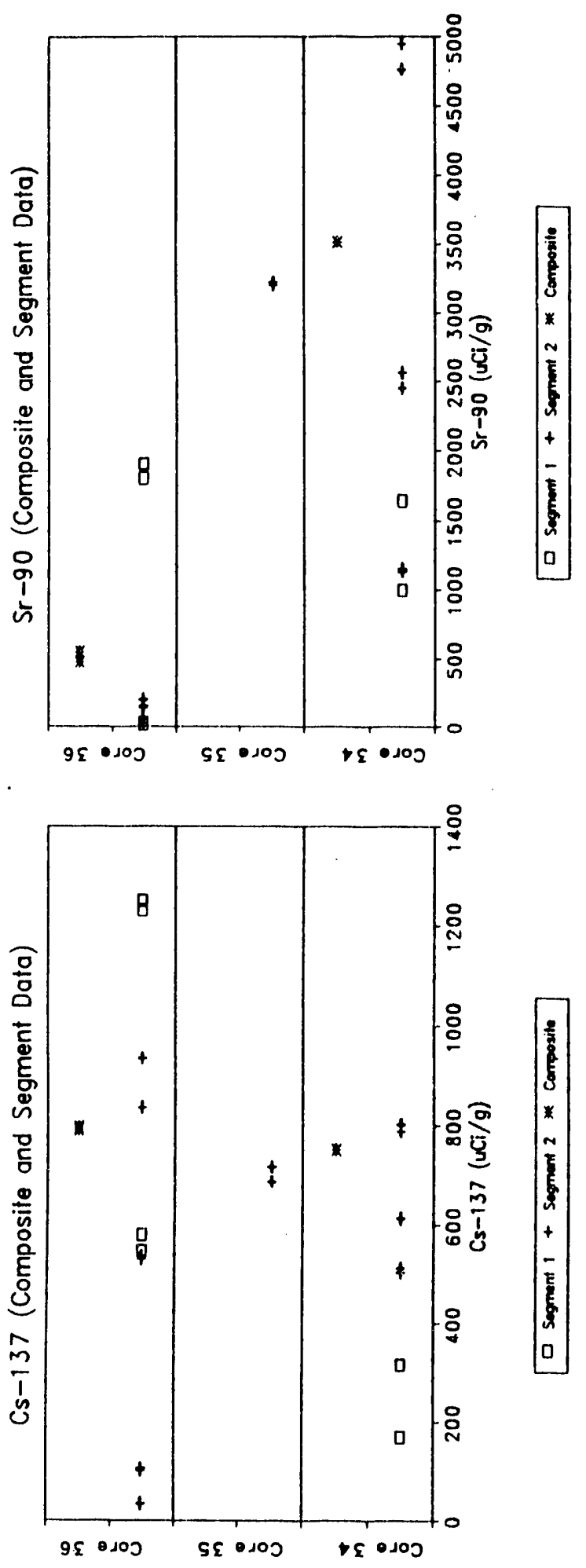
PAGE 5 OF 6
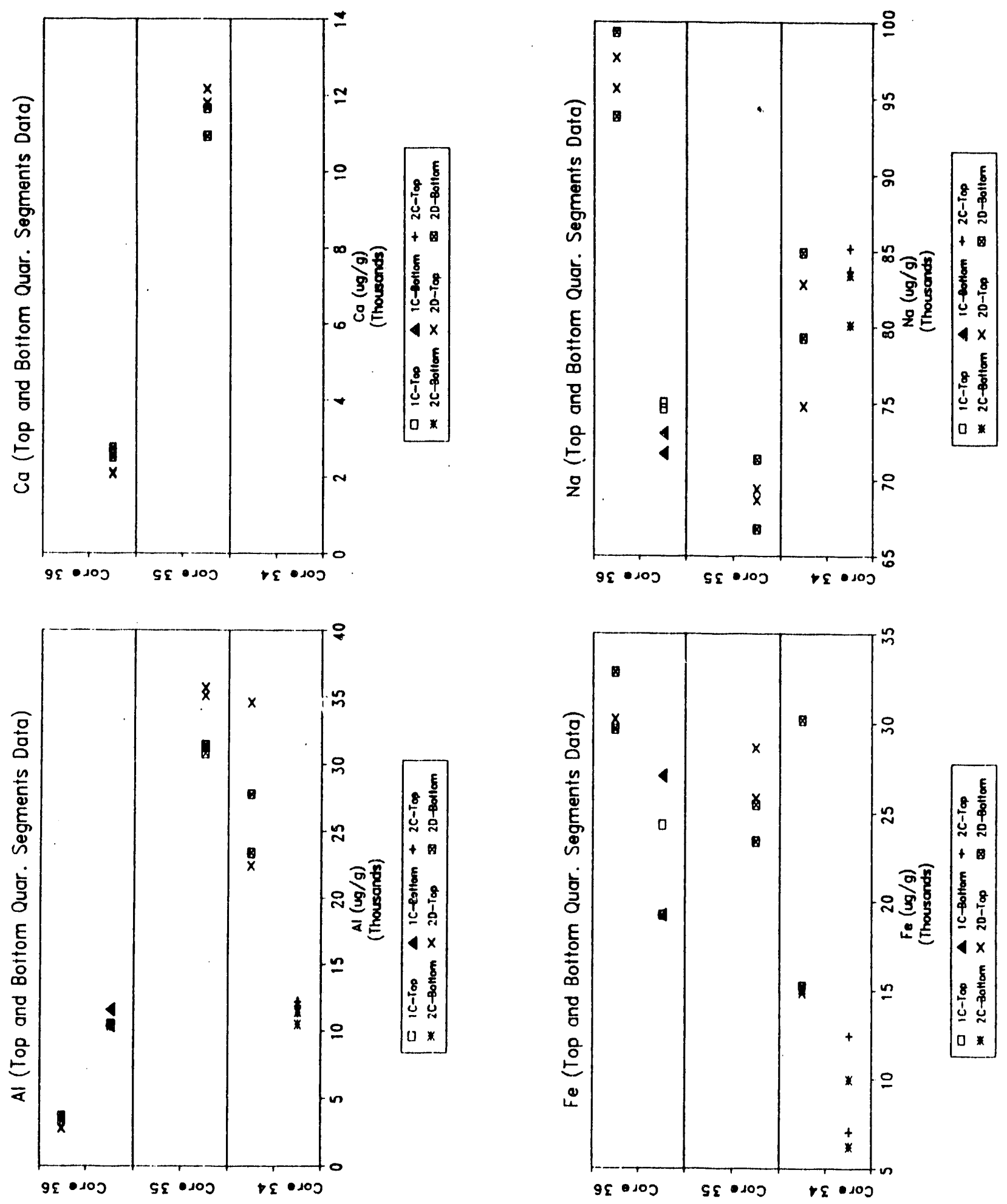

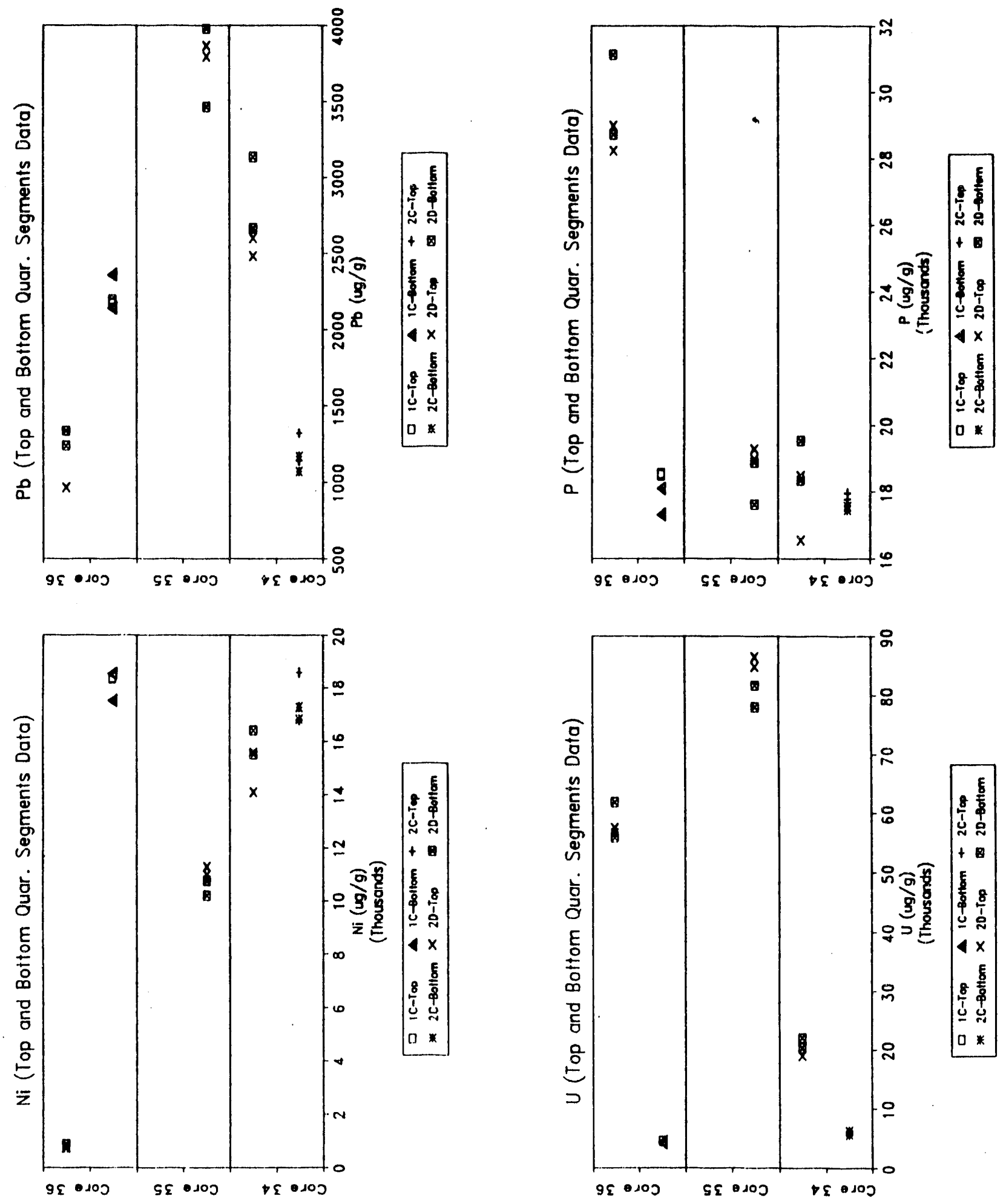
WHC-EP-0640

APPENDIX C

MISCELLANEOUS DATA

APP $C-i$ 
WHC-EP-0640

This page intentionally left blank.

APP $C-i i$ 
WHC-EP-0640

Page 1 or 1

\section{MEETING MINUTES}

Subject: ENERGY MEASUREMENTS FOR OISQUALIFYING WASTE TANKS FROH WATCH LISTS

\begin{tabular}{|c|c|c|c|}
\hline ro: Distribution & & BUILDING: & MO-037 \\
\hline FROM: J.R. Jewetth & & & \\
\hline Mesting Oate & Number Attending & & \\
\hline $10 / 22 / 92$ & 6 & & $\cdot$ \\
\hline
\end{tabular}

Distribution:

$\begin{array}{llll}\text { H. Babad } & \text { R2-08* } & \text { R. P. Marshall } & T 6-14 \\ \text { D. B. Bechtold } & T 6-50^{\star} & \text { A. F. Noonan } & \text { R2-12 } \\ \text { M. L. Bell } & T 6-16 & \text { J. C. Person } & T 6-50^{\star} \\ \text { R. J. Cash } & \text { R2-32 } & \text { J. P. Sloughter } & T 6-07 \\ \text { D. A. Dodd } & T 6-50 & \text { H. E. Smith } & \text { R2-12* } \\ \text { D. J. Hert } & T 6-30^{\star} & \text { J. H. Tillman } & T 6-30 \\ \text { J. R. Jewett } & T 6-50^{\star} & \text { W. I. Winters } & T 6-50\end{array}$

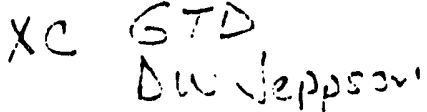

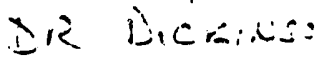

$$
\begin{aligned}
& \text { RD CR=U: } \\
& \text { GL RONSENE. } \\
& \text { MIJ CRIPRER } \\
& \text { RD SCHEEL } \\
& \text { GF SCHIEFELRE } \\
& \text { Ji topkid: } \\
& =0 \text { toptases }
\end{aligned}
$$

* Attendees

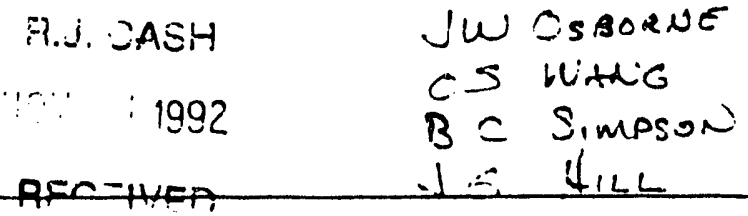

Harry Babad is preparing to develop a criterion based on energetic measurements for. removing tanks from the watch lists. He wants the labs to be prepared for the sample loads which may occur as a result of this criterion. Initial thoughts about the criterion are as follows:

If the exotherm of the material is $<75 \mathrm{cal} / \mathrm{g}$, there should be no further concern. If moisture is $>25 \%$, the 1 imit of concern may be raised to $125 \mathrm{cal} / \mathrm{g}$. These are figures determined by Babad in consultation with a number of nationally recognized experts in the field.

The suggestion is that if the differential scanning calorimetry exotherms exceed this level, then more in-depth examination, such as adiabatic calorimetry, would be necessary. Adiabatic calorimetry would give such information as initiation temperature, reaction rate, and propagation rate. Babad estimates that perhaps there might be 20 tanks that exceed these limits. (This number is, of course, open to debate.) There would also be need for measurements to support studies of synthetic materials.

A number of deficiencies of adiabatic calorimetry and thoughts about improvement were mentioned during the meeting. Keeping in spirii of the meeting, which was by and large a brain storming session, the ideas are presented here in no particular order.

1. Do we have enough tools? Adiabatic is slow, labor intensive, dose rate high. It uses too much sample; we have just one. Does the Accelerating Rate Calorimeter (ARC; by Columbia Scientific) offer any advantage over the Fauske Reactive System Screening Tool? If it is too big, could it be rodified?

$54 \cdot 3000-100$ (4/58) (EF) GEFO11 Mesting Minutes 
2. Do we have the right tools to work up the results? We shou computer. Would Chemometric tools help? (Eric Wyse at PNL Could data work-up be more automated?

3. Do we have enough capacity?

4. Do we have proper documentation for our measurements? ile $u$ test reports now. When sample load increases, we will need efficient system to get data to engineers, programs, and ex. The "data package" system used for single-shell tank charac" fast enough.

5. We need to develop back-ups to current thermal analysis stat

6. We need to have a low-temperature drying method for adiabat: controlled well enough to allay any suspicion that the sampl chemical energy before the actual adiabatic measurement.

No formal actions were taken or assigned at this meeting. These minut way to raise general awareness that needs for direct measurement of wa energetics has the potential for dramatic growth. The laboratory shou respect to knowledge of methods, manpower, and equipment. 
Westinghouse

From: Waste Characterization Analysis

Phone: $\quad 6.1639$ HO-34

Date: $\quad$ March 23, 1993

Subject: HEAT LOAD DETERMINATION OF TANK 241-C-112

To:

B. C. Simpson

R2 - 12

cc:

$\begin{array}{ll}\text { R. J. Cash } & \text { R2-32 } \\ \text { W. L. Knecht } & H 0-34\end{array}$

JMM File/LB

$\mathrm{HO}-34$

On February 2, 1993, you requested that I perform a heat load determination on tank 241-C-112. You provided the thermocouple readings and placement depths. Accordingly, an analys is was performed. The value determined for the heat load of the tank was $8,100 \mathrm{Btu} / \mathrm{h}(2.374 \mathrm{~kW})$. The conductivity of the waste was determined to be $.70 \mathrm{Btu} / \mathrm{h}-\mathrm{ft}-{ }^{\circ} \mathrm{F}$. The accuracy limits of the heat load determination were considered to be plus or minus $1,000 \mathrm{Btu} / \mathrm{h}$.

The analysis utilized the data you provided as the primary data. The boundary conditions for the surrounding soil were a conductivity of $.6 \mathrm{Btu} / \mathrm{h}-\mathrm{ft}-{ }^{\circ} \mathrm{F}$, and a constant temperature of $55^{\circ} \mathrm{F}$ at 200 feet below the soll surface, and a forced convection heat sink of $54^{\circ} \mathrm{F}$ at the soil surface. These values are those used in previous analyses, except for the soil conductivity, which is that for slightly better than $10 \%$ saturated sand. This value is the best estimate of soil conductivity to date. A copy of the workbook is included in this letter.

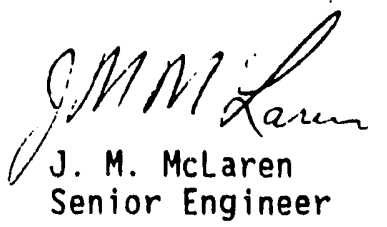

Checked by:

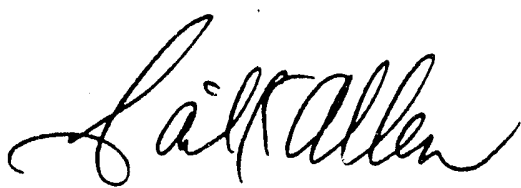

Senior Engineer

G. K. Allen

Principal Enineer

bab

Attachment

CONCURRENCE :

Walter Z. Freecht

W. L. Knecht, Manager

Waste Characterization Analys is

Henford Operations and Enoinearing Contractor for the US Doperement of Energy 
Tank 241-C-112 workbook

Brett Simpson called and wanted a heat load on tank $\mathrm{C}-112$. I have aquired prints H-2-37912, Riser Elevations, and H-2-1744, Tank Farm Riser and Nozzle Elevations. I also have print W-7387, $75 \mathrm{Ft}$ Diameter Tanks Building No. 241 Concrete Details of Tank. Drawing W-7387 shows that the distance from the bottom of the tank wall to the top of the liner is $18 \mathrm{ft}$, and the distance from the top of the liner to the bottom center of the dome is $12 \mathrm{ft}$. The distance from the center of the bottom to the bottom of the tank wall is 1 $\mathrm{ft}$, as is the thickness of the concrete dome. Drawing H-2-1744 shows the same dimensions, except for the distanc from the top of the liner to the bottom center of the dome, which is not shown at all. The drawing shows that the elevation of the bottom center of the tank is $608 \mathrm{ft}$, and the elevation of the top of the risers on the south side is $646.12 \mathrm{ft}$, and on the north side 645.69 $\mathrm{ft}$. The average elevation is $645.91 \mathrm{ft}$.

The distance to the top of the tank from the bottom is $1+18+12+1$ $\mathrm{ft}=32 \mathrm{ft}$. The elevation is $608+32=640 \mathrm{ft}$. The depth of the dirt cover is $645.91-640=5.91 \mathrm{ft}$. This is a little less than usually considered. The depth of soil cover is usually from 7 to 9 feet. Drawing H-2-37912. shows that the bottom elevation of the tank is $607.00 \mathrm{ft}$. This would give a soil cover depth of $6.91 \mathrm{ft}$. I think that this is more probable, and that print $H$. 2-37912 is more accurate than H-2-1744 in this respect. So I will use a depth of $6.91 \mathrm{ft}$.

The model will be developed by modifying the C-109 model I built for the heat load analysis for WHC-SD-WM-ER-139, Heat Load and Thermal Characteristics Determination for Selected Tanks. The development of the C-109 model is covered in detail in WHC-SD-WM-TI-502, the Task Record (Engineering Notebook) for the above report. This model's noding diagram is shown as on Page 2. The first thing to do is to get the top and bottom dimensions correct. From measurements taken from Drawing W-7387, the top of the tank dome is $22.89 \mathrm{ft}$ above the reference 1 ine. The program VOLUME2. BAS was developed to calculate the volume of the tank above and below the drawing reference $l$ in for various radii. This program is shown on Page 3 , and the input tables are shown on Page 4. Running VOLUME2.BAS for the radii 0 to $10.11 \mathrm{ft}$ gives an average height of $22.62 \mathrm{ft}$. The difference is $.27 \mathrm{ft}$. So the underside of the tank top is $6.91+1$ (concrete thickness) $=7.91 \mathrm{ft}$ below the surface of the soil. The elevation of the region is $7.91+.27=8.18 \mathrm{ft}$. The model showed 8.05 
WHC-EP-0640

Tank 241-C-112 workbook

TANK 241-C-109 MODEL

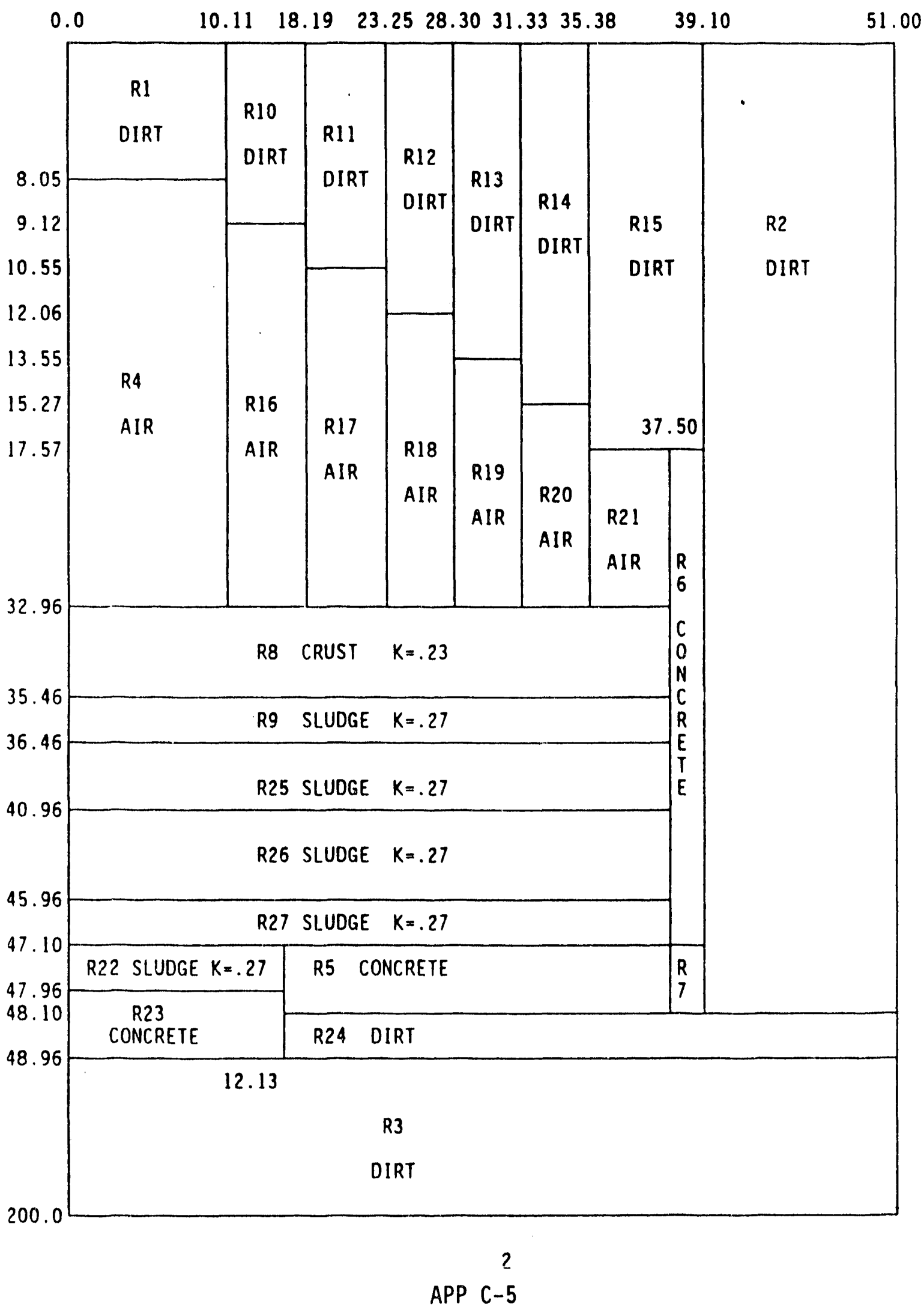




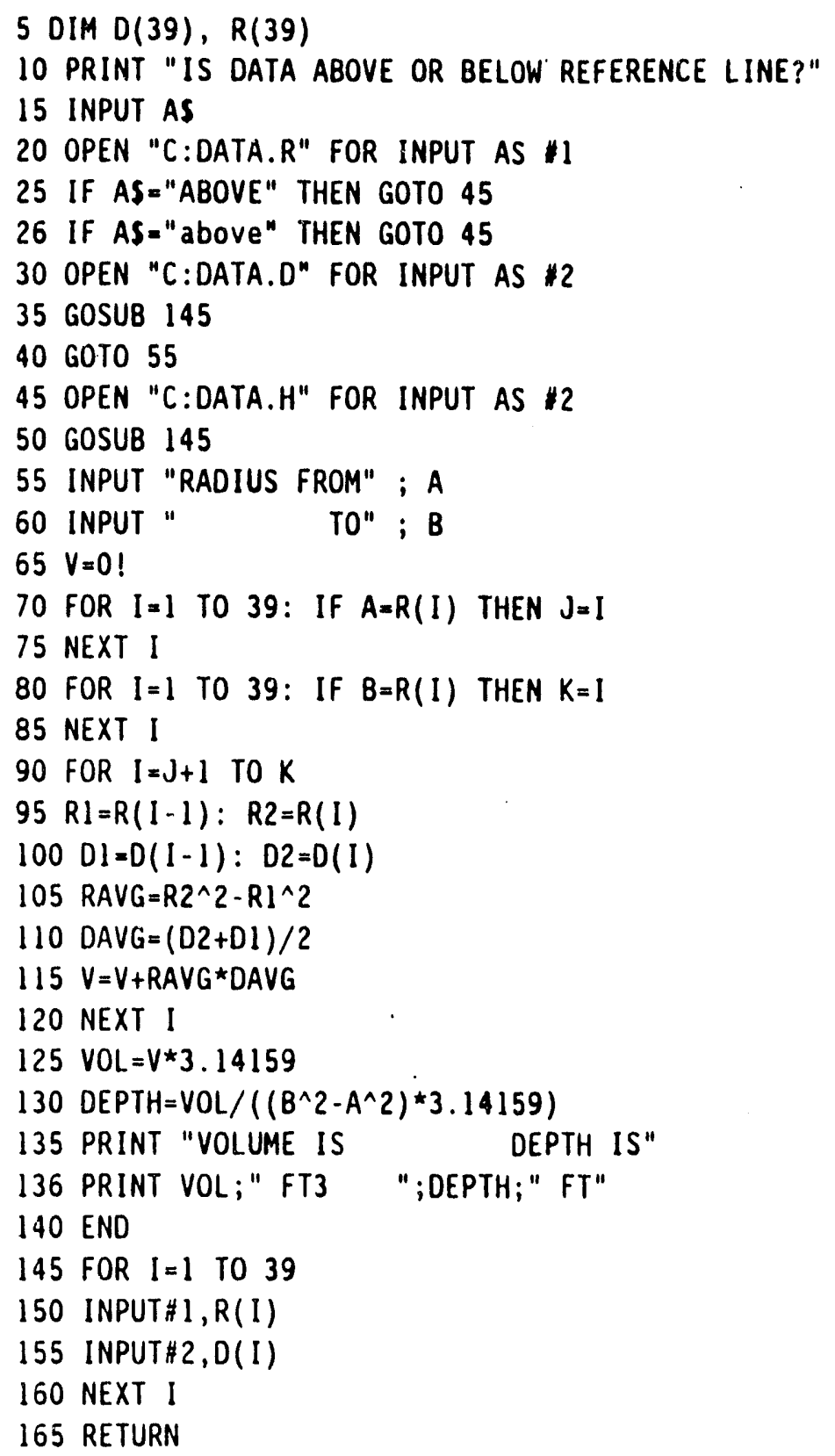


WHC-EP-0640

Tank 241-C-112 workbook

INPUT FOR VOLUME2.BAS

RADIUS

DEPTH BELOW REFERNCE

HEIGHT ABOVE REFERENCE

\begin{tabular}{|c|c|c|c|}
\hline 0. & 7.43 & 22.89 & \\
\hline 1.01 & 7.43 & 22.89 & . \\
\hline 2.02 & 7.43 & 22.89 & \\
\hline 3.03 & 7.39 & 22.89 & \\
\hline 4.04 & 7.38 & 22.84 & \\
\hline 5.05 & 7.38 & 22.79 & \\
\hline 6.06 & 7.35 & 22.74 & \\
\hline 7.08 & 7.33 & 22.64 & \\
\hline 8.09 & 7.33 & 22.54 & \\
\hline 9.10 & 7.33 & 22.39 & \\
\hline 10.11 & 7.30 & 22.29 & \\
\hline 11.12 & 7.28 & 22.14 & \\
\hline 12.13 & 7.26 & 22.01 & \\
\hline 13.14 & 7.23 & 21.83 & \\
\hline 14.15 & 7.20 & 21.63 & \\
\hline 15.16 & 7.18 & 21.48 & \\
\hline 16.17 & 7.13 & 21.28 & \\
\hline 17.18 & 7.13 & 21.02 & \\
\hline 18.19 & 7.08 & $20.77^{-}$ & \\
\hline 19.20 & 7.05 & 20.57 & \\
\hline 20.22 & 7.02 & 20.27 & \\
\hline 21.23 & 6.97 & 20.01 & \\
\hline 22.24 & 6.92 & 19.76 & \\
\hline 23.25 & 6.87 & 19.46 & \\
\hline 24.26 & 6.82 & 19.15 & \\
\hline 25.27 & 6.77 & 18.85 & \\
\hline 26.28 & 6.72 & 18.45 & \\
\hline 27.29 & 6.67 & 18.14 & \\
\hline 28.30 & 6.62 & 17.74 & \\
\hline 29.31 & 6.57 & 17.33 & \\
\hline 30.32 & 6.52 & 16.93 & \\
\hline 31.33 & 6.45 & 16.53 & \\
\hline 32.35 & 6.42 & 16.12 & \\
\hline 33.36 & 6.36 & 15.46 & \\
\hline 34.37 & 6.25 & 14.81 & \\
\hline 35.38 & 5.86 & 14.10 & \\
\hline 36.39 & 5.10 & 13.19 & \\
\hline 37.40 & 3.54 & 12.13 & \\
\hline 37.50 & 0 & 12.08 & \\
\hline
\end{tabular}

APP $C-7$ 
$\mathrm{ft}$. So change all the dome regions by $8.18-8.05=.13 \mathrm{ft}$. The bottom is done similarly. VOLUME2.BAS calculates the average depth below the reference 1 ine for the radii 0 to $12.13 \mathrm{ft}$ to be $7.33 \mathrm{ft}$. Thebottom center is $7.43 \mathrm{ft}$. the difference is 7.33 . $7.43=-.10 \mathrm{ft}$. The tank bottom is $645.91-607=38.91 \mathrm{ft}$. The deptr, of the region of the tank bottom center is $38.91-.10=38.81 \mathrm{ft}$. The difference between the two tank bottom regions is $47.96-47.10=.86 \mathrm{ft}$. So the second region is at $38.81-.86=37.95$ $\mathrm{ft}$. These regions are $.5 \mathrm{ft}$ thick.

So now construct the model. Using the noding diagram on Page 2, add .13 to all the vertical dimension values in the airspace regions. The tank bottom vertical dimensions will be 38.81 to 39.31 for the lower tank bottom, and 37.95 to 38.45 for the outer (urper) tank bottom. All the waste regions above the tank bottom can be consolidated into oneregion, for two waste regions, the one over the "step" in the bottom, and the one above the entire bottom. Also, in the interest of better continuity, renumber all the regions.

To determine the waste depth for the model, take the provided data which shows a depth of $3.79 \mathrm{ft}$. This is measured at the outer riser location, taken to be $33.5 \mathrm{ft}$ from the tank center. At that location the measurements from drawing W-7387 show the tank bottom to be $6.36 \mathrm{ft}$ below the reference 1 ine. The center position is 7.43 feet below the reference line, a difference of $1.07 \mathrm{ft}$. There is a difference of $6.36-3.79=2.57 \mathrm{ft}$ between the measured top of the sludge and the reference 1 ine. Running VOLUME2.BAS for the volume below the reference line gives a volume of $28991 \mathrm{ft}^{3}$. With a tankd diameter of $75 \mathrm{ft}$ and a height of $2.57 \mathrm{ft}$, there is a volume of $11353.91 \mathrm{ft}^{3}$ between the reference 1 in and the top of the sludge. This means there is $28991.15-11353.91=17637.84 \mathrm{ft}^{3}$ of sludge. Region 23 of the model, the small sludge volıme at the center bottom is $12.13 \mathrm{ft}$ in radius and $.86 \mathrm{ft}$ high for a volume of $397.53 \mathrm{ft}^{3}$. This means there is 17637.84 . $397.53=17240.31 \mathrm{ft}^{3}$ of sludge in Region 22 . This region is $3.90 \mathrm{ft}$ high. So the top of the sludge is at $37.95-3.90=34.05 \mathrm{ft}$. The thermor suple positions should be placed to be correct when measured from the top of the sludge. There will be an error of .11 ft at the bottom, but this should be acceptable. The noding diagram is shown on Page 6

Now to work up the data. The temperature data from the $T / C$ trees in Risers 1 and 5 is shown on Page 7 , with the elevations of the individual thermocouples on Page 8 . Plots of the data, with the data locations measured from the sludge surface are shown on Page 9. The averages will be used to make the data string to be matched.

Now start the iteration process. From the temperature data 1 will start at 7500 $\mathrm{BTU} / \mathrm{hr}$, and use a waste conductivity of $.65 \mathrm{BTU} / \mathrm{hr}-\mathrm{ft}-{ }^{\circ} \mathrm{F}$. The run shows this is pretty low. Try again at $9000 \mathrm{BTU} / \mathrm{hr}$. This one is too high, but in the ballpark. Drop down to $7750 \mathrm{BTU} / \mathrm{hr}$. This one shows we're getting close. Try $8000 \mathrm{BTU} / \mathrm{hr}$. Real close. Now change the conductivity to something a little higher to better match the slope of the data. Try $.70 \mathrm{BTU} / \mathrm{hr}-\mathrm{ft}-{ }^{\circ} \mathrm{F}$. Just about dead on. Looks like the power is $8000 \mathrm{BTU} / \mathrm{hr}$ with a conductivity of $.7 \mathrm{BTU} / \mathrm{hr}-\mathrm{ft}-{ }^{\circ} \mathrm{F}$. Plots of the results of these runs are shown on Page 10. The accuracy spread is the spread of the data. A 7000 BTU/hr run is plotted with the $8000 \mathrm{BTU} / \mathrm{hr}$ run and the $9000 \mathrm{BTU} / \mathrm{hr}$ run, against the data on page 12 . Looks like a $\pm 1000 \mathrm{BTU} / \mathrm{hr}$ will do the trick. So I will use that. 
WHC-EP-0640

Tank 241-C-112 workbook

TANK 241-C-112 MODEL

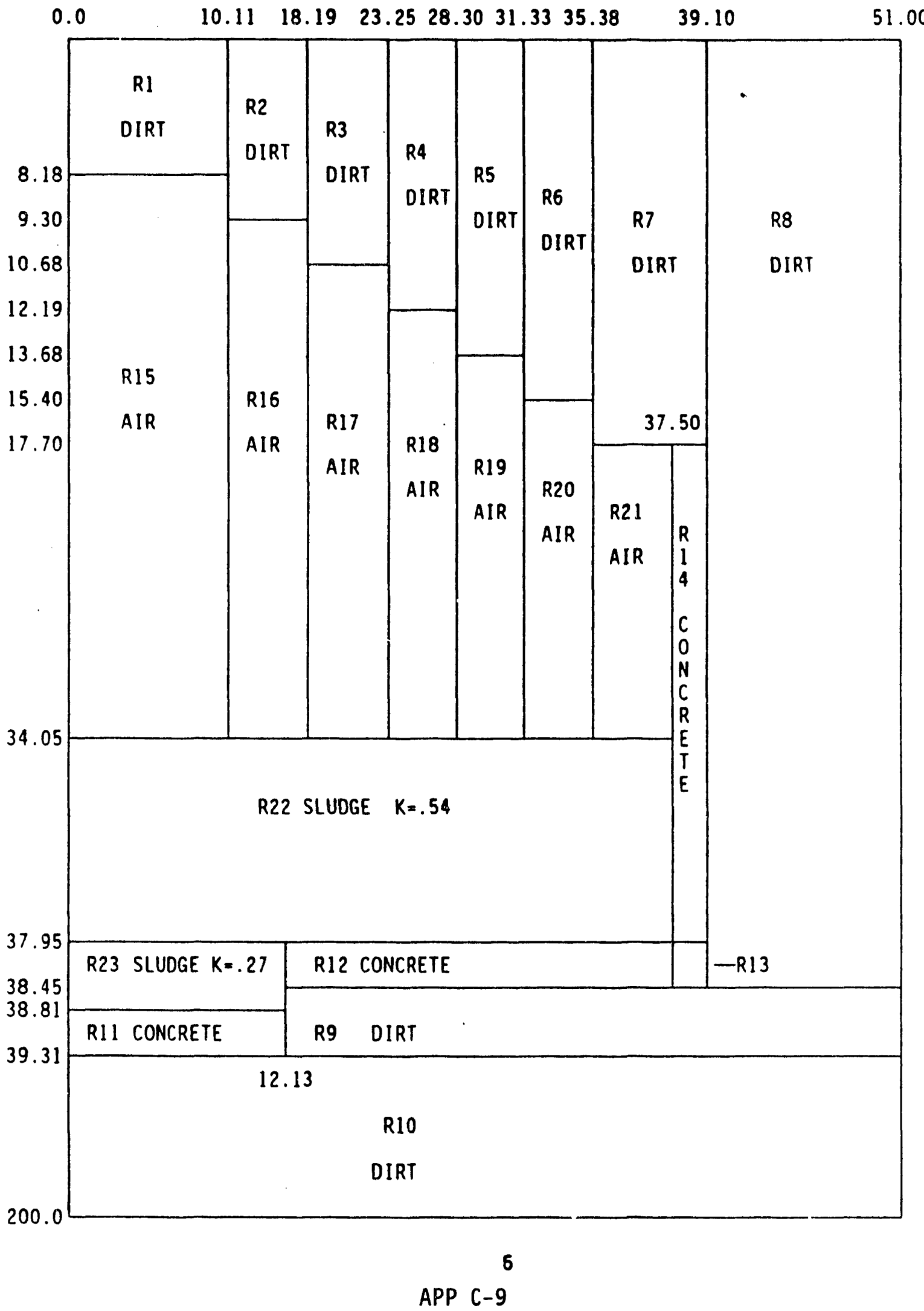


WHC-EP-0640

Tank 241.c-11: wor.tebul.

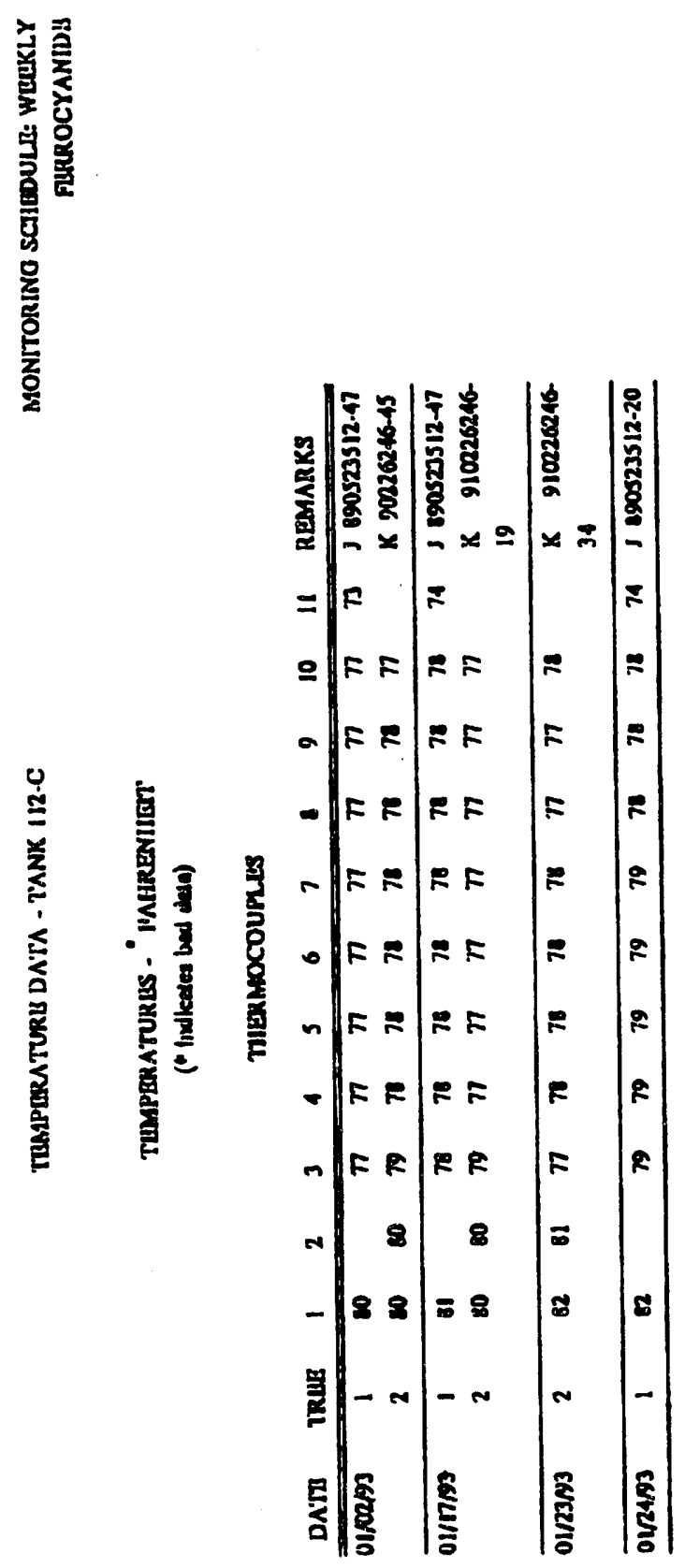

7 
6. L. Borsheim, et. al.

Page 9 of 10

May 20, 1992

\begin{tabular}{|c|c|c|c|}
\hline \multicolumn{2}{|c|}{ 241-C-112, Riser 1. Existing Probe } & \multicolumn{2}{|c|}{ Maste Level $=3.79$ feet } \\
\hline \multirow{2}{*}{$\begin{array}{c}\text { Thersocouple } \\
1\end{array}$} & \multirow{2}{*}{$\frac{\text { Relative Elevation (ft) }}{1.7}$} & \multicolumn{2}{|c|}{ Monitor by Tmacs } \\
\hline & & Yos & \\
\hline 2 & 3.7 & Yas & \\
\hline 3 & 5.7 & Yes & \\
\hline 4 & 7.7 & & Mo \\
\hline 5 & 9.7 & & No \\
\hline 6 & 11.7 & & No \\
\hline 7 & 13.7 & & No \\
\hline 8 & 15.7 & Yes & \\
\hline 9 & 17.7 & & Ho \\
\hline 10 & 21.7 & & Ho \\
\hline 11 & 25.7 & & No \\
\hline
\end{tabular}

\begin{tabular}{|c|c|c|c|}
\hline \multicolumn{2}{|c|}{ 241-C-112, Riser 5, New Probe } & \multicolumn{3}{|c|}{ Naste Level = 3.79 feet } \\
\hline Thermocouplc 1 & Relative Elovation (ft) & Monizor by TMACs \\
\hline 1 & 1.3 & Yes & \\
\hline 2 & 2.1 & Yes & \\
\hline 3 & 3.0 & Yes & \\
\hline 1 & 3.8 & Yes & \\
\hline 5 & 4.6 & Yes & \\
\hline 6 & 7.4 & & No \\
\hline 7 & 9.5 & & No \\
\hline 8 & 11.6 & & Nu \\
\hline 9 & 13.6 & & No \\
\hline 10 & 15.7 & Yes & \\
\hline
\end{tabular}

8 
WHC-EP-0640

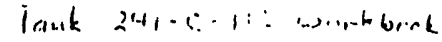

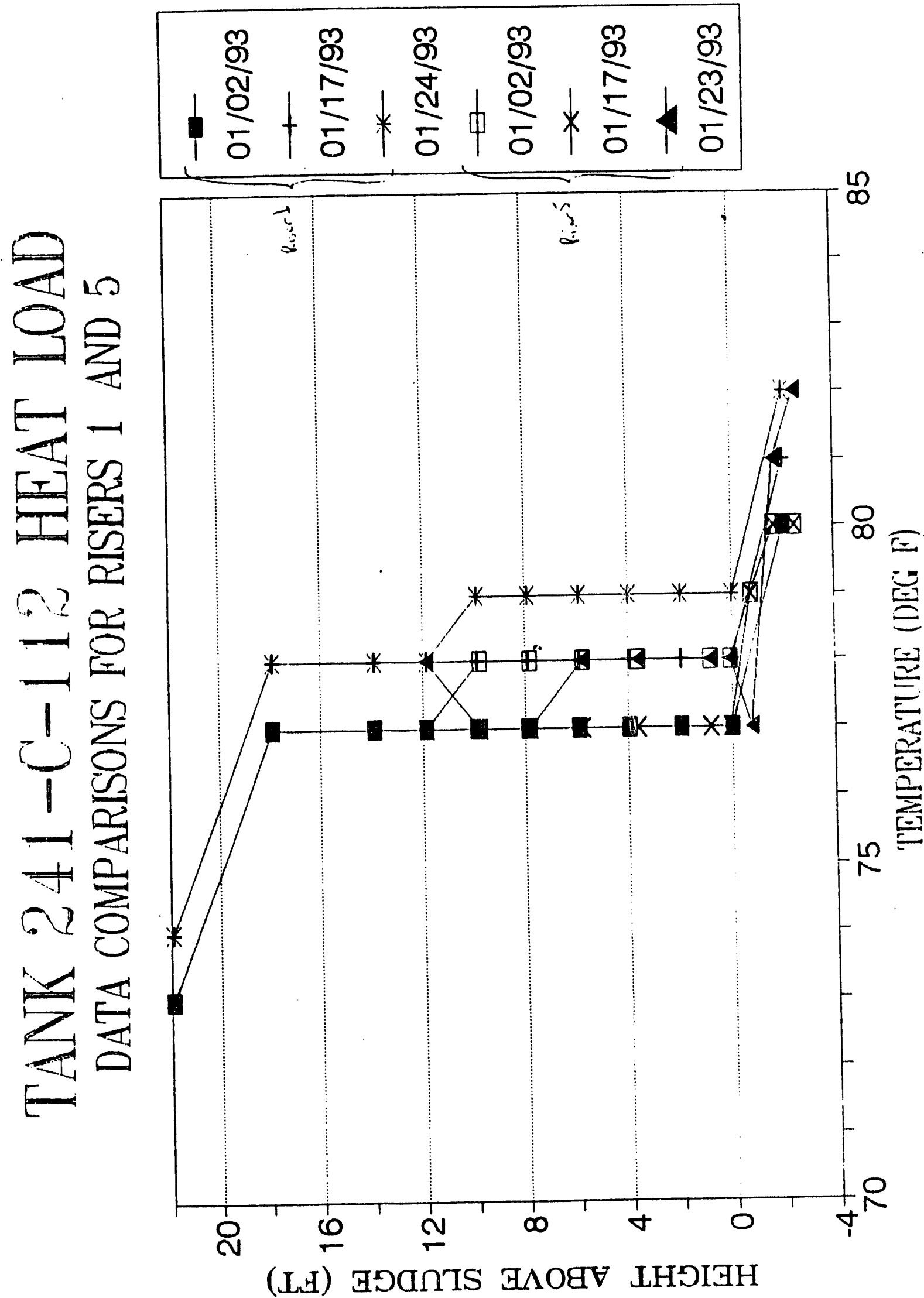


WHC-EP-0640

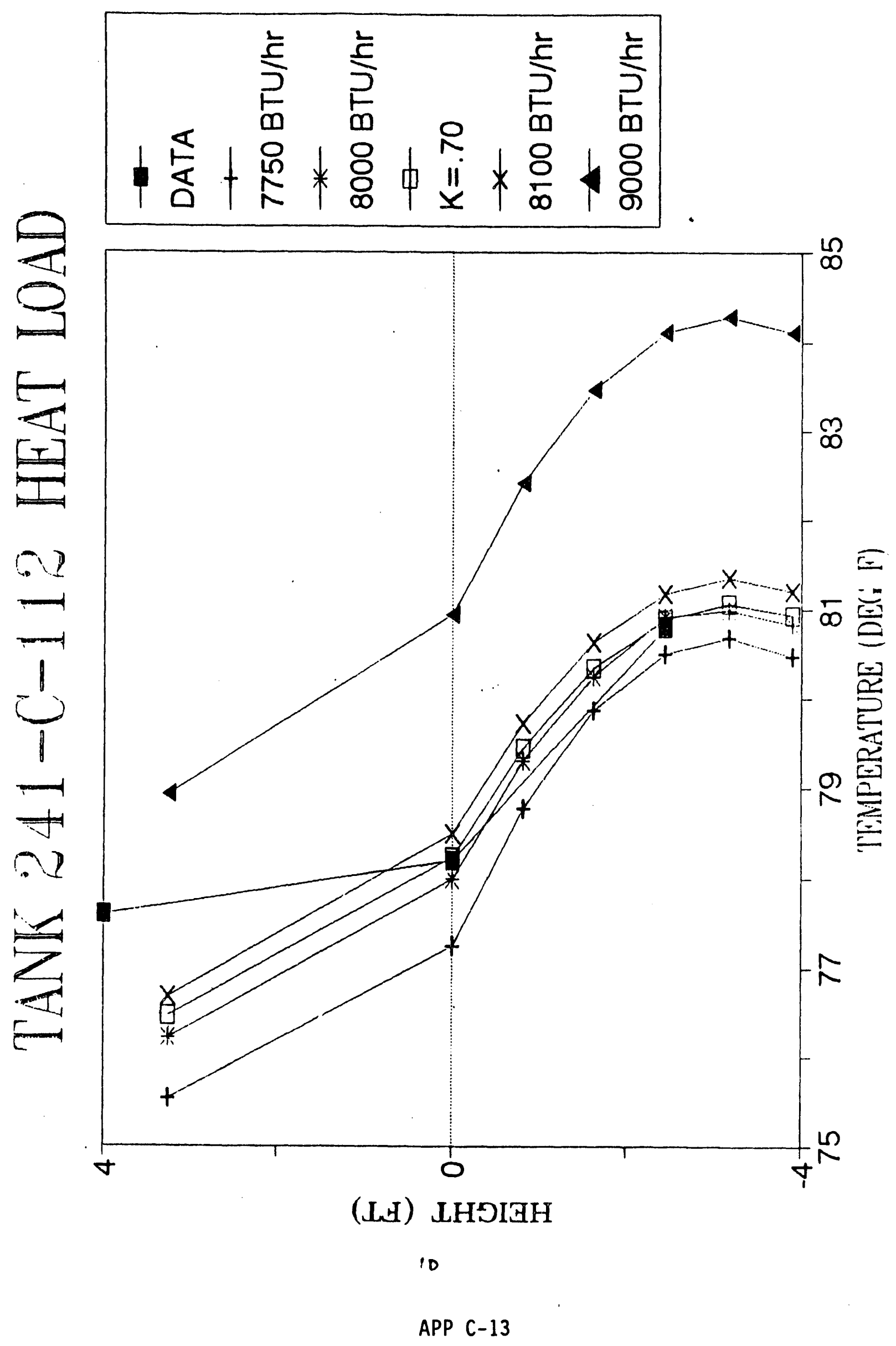




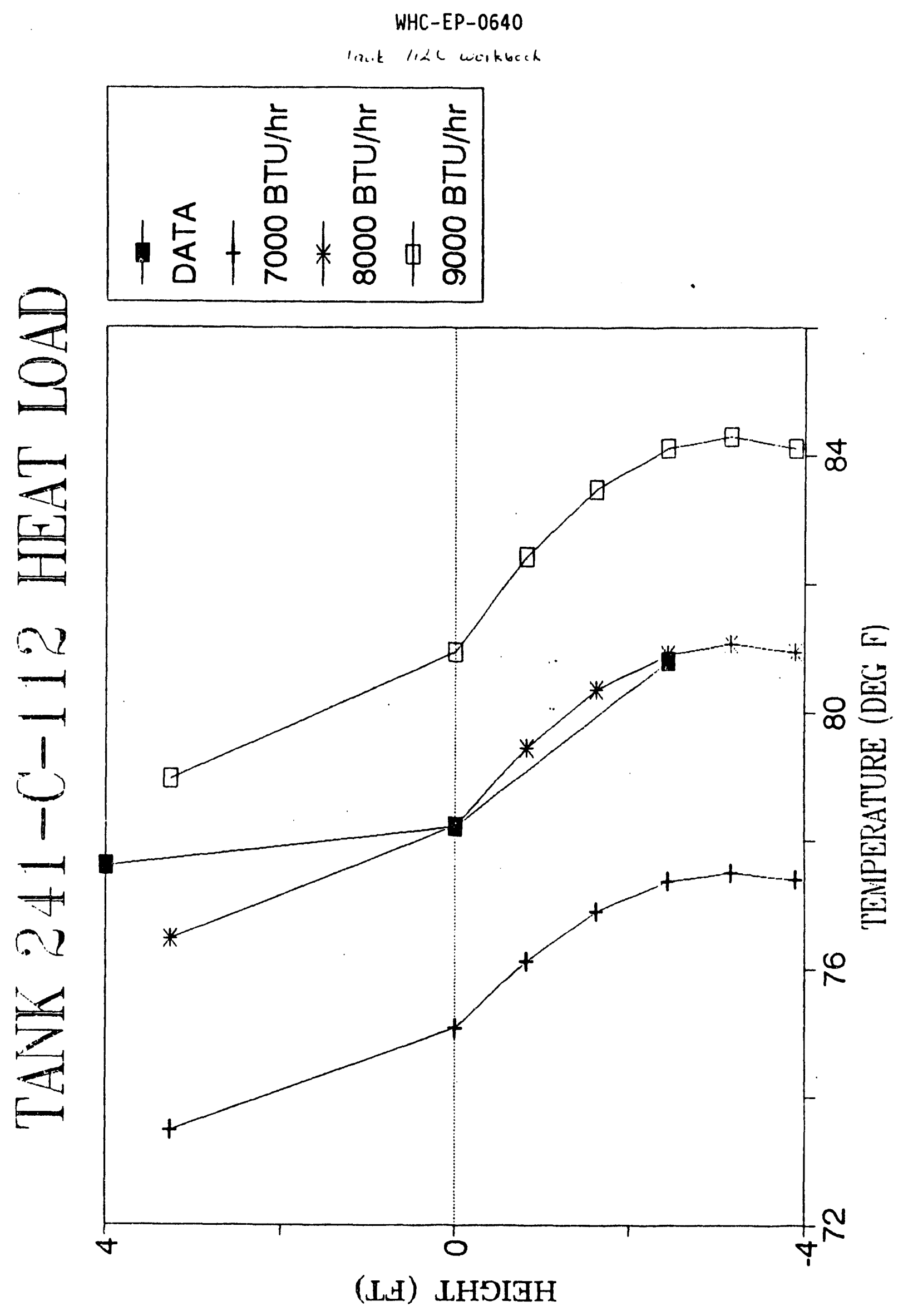

12

APP $\quad$ - -14 


\section{DISTRIBUTION}

\section{Number of Copies}

\section{OFFSITE}

25

U.S. Department of Energy

EM-35, Trevion.II

Washington, D.C. 20585

John C. Tseng

1

U.S. Department of Energy

Savannah River Operations office P.0. Box A

Aiken, South Carolina 29808

Thomas C. Temple

1

Charles S. Abrams

1987 Virginia

Idaho Falls, ID 83404

1

David 0. Campbell

102 Windham Road

Oak Ridge, TN 37830

1

Fred N. Carlson

6965 North 5 th West

Idaho Falls, ID 83401

Donald T. Oakley

409 12th Street SW, Suite 310

Washington, DC 20024-2188

Arl in K. Postma

3640 Ballard Road

Dallis, Oregon 97338

William R. Prindle 1556 Crestl ine Drive

Santa Barbara, CA 93105

Alfred Schneider 5005 Hidden Branches Drive Dunwoody, GA 30338

Air Products \& Chemicals. Inc. 7201 Hamilton Blvd Allentown, PA 18195-1501

George E. Schmauch 


\section{DISTRIBUTION (Continued)}

Number of Copies

OFFSITE

1

2

1

1

1

1

1

Battelle Columbus Laboratories 505 King Avenue

Columbus, $\mathrm{OH}$ 43201-2693

James A. Gieseke

Brookhaven National Laboratory Upton, NY 11973

Kama 1 K. Bandyopadhyay

Morris Reich

Design Science, Inc.

163 Witherow Road

Sewickley, PA 15143

Gary Powers

Fauske and Associates, Inc. 16W070 W. 83rd St.

Burr Ridge, IL 60521

Hans K. Fauske

Florida State University Department of Chemistry B-164

Tallahassee, FL 32306

Greg R. Choppin

Harvard University 295 Upland Avenue Newton Highlands, MA 02161

Melvin W. First

Hazards Research Corporation 200 Vailey Road, Suite 301

Mt. Arlington, NJ 07856

Chester Grelecki 
DISTRIBUTION (Continued)

Number of Copies

OFFSITE

1

Lawrence Livermore National Laboratory

P.0. Box 808, L-221

Livermore, CA 94550

Billy C. Hudson

4

Los Al amos National Laboratory

P.0. Box 1663

Los Alamos, NM 87545

Steve F. Agnew

Steve W. Eisenhawer

Thomas E. Larson

L. Harold Sullivan

1

MIT/Department of Nuclear Engineering 77 Massachusetts Ave. Room 24-102

Cambridge, MA 02139

Mujid S. Kazimi

1

Nuclear Consulting Services, Inc.

P.0. Box 29151

Columbus, $\mathrm{OH} 43229$

J. Louis Kovach

Oak Ridge National Laboratory

Emory D. Collins

P.0. Box 2008

7930, MS-6385

Oak Ridge, TN 37831-6385

Charles W. Forsberg

P.0. Box 2008

MS-6495

Oak Ridge, TN 37831-6495

Thomas S. Kress

P.0. Box 2009

9108, MS-8088

0ak Ridge, TN 37831-8088 
WHC-EP-0640

\section{DISTRIBUTION (Continued)}

Number of Copies

\section{OFFSITE}

1

Rice University

5211 Paisley

Houston, TX 77096

Andrew S. Veletsos

1

Sandia National Laboratory

P.0. Box 5800

Albuquerque, NM 87185

Scott E. Slezak

4

Science Applications International Corporation 12850 Middlebrook Road

Trevion I, Suite 300

Germantown, MD 20874

Ray S. Daniels (3)

John M. Saveland

1

University of South Carolina

Department of Electrical and Computer Engineering Swearingen Engineering Center

Columbia, SC 29208

Joseph S. Byrd

1

University of Washington

Center for Process Analytical Chemistry

Chemistry Department BG-10

Seattle, WA 98195

Bruce R. Kowalski

1

Vanderbilt University

P.0. Box 1596, Station B

Nashville, TN 37235

Frank L. Parker 


\section{DISTRIBUTION (Continued)}

\section{Number of Copies}

\section{ONSITE}

18

U.S. Department of Energy. Richland Field Office

R. F. Christensen (8)

A4-02

J. M. Clark (3)

R. E. Gerton

A4-02

A. G. Krasopoulos

A4-02

T. Noble

R. 0. Puthoff

Public Reading Room

RL Docket File (2)

A5 -55

A4-02

A5- 10

Al- 65

A3-11

11

\section{Pacific Northwest Laboratory}

R. T. Allemann

K $7-15$

S. A. Bryan

B. M. Johnson

P7 -25

$\mathrm{K} 1-78$

M. A. Lilga

P8-38

S. G. Mckinley

P7 -22

K. H. Pool

R. D. Scheele

P8 -44

G. F. Schiefelbein

P7 -25

D. M. Strachan

$P 8-38$

$\mathrm{K} 2-38$

J. M. Tingey

P7 -25

PNL Technical Files

Westinghouse Hanford Company
H. Babad
D. B. Bechtold
J. R. Bel1
J. B. Billetdeaux
R. J. 87 anchard
T. D. Blankenship
D. C. Board
G. L. Borsheim
V. C. Boyles
S. L. Bradley
J. G. Burk
R. J. Cash (5)
M. D. Crippen
G. M. Christensen
R. D. Crowe
S. J. Dechter
C. DeFigh-Price

$\mathrm{R} 2-08$

T6-50

R3-09

$\mathrm{R} 2-08$

$\mathrm{R} 1-17$

B1-58

S1 -57

R2-11

R1-49

B3-06

B3 -25

R2-32

[5-3]

H4-2I

H4-62

R2-50

R2-31 
WHC-EP-0640

\section{DISTRIBUTION (Continued)}

Number of Copies

ONSITE

Westinghouse Hanford Company (cont inued)

J. L. Deichman B1-59

D. R. Dickinson

L5-3]

G. T. Dukelow (2)

$\mathrm{R} 2-32$

G. L. Dunford

C. J. Forbes

$\mathrm{R} 1-51$

K. D. Fowler

$\mathrm{R} 1-08$

G. L. Fox

G. T. Frater

J. C. Fulton

K. A. Gasper

S. D. Godfrey

J. M. Grigsby

R2-11

L5-0]

R $1-5]$

R2-31

R2-08

R I-51

T. W. Halverson

H4 -62

D. G. Hamrick

$\mathrm{R} 2-52$

H. D. Harmon

$\mathrm{R} 1-51$

J. M. Held

J. M. Henderson

$\mathrm{R} 2-52$

R3-12

S4-55

D. L. Herting

T6-09

J. D. Hopkins

R2-11

R. D. House

$R 2-83$

M. W. Howard

$\mathrm{R} 2-08$

L. L. Humphreys

R2 -50

M. N. Islam

R3-08

D. W. Jeppson

L5-3]

J. R. Jewett

T6-50

D. R. Johnson

R2-08

N. W. Kirch

R2-11

W. L. Knecht

HO $0-34$

C. A. Kuhlman

B3-30

M. Kummerer

H4 -62

D. L. Lenseigne

$\mathrm{R} 2-75$

D. A. Marsh

J. D. McCormack

A3-05

N. C. McDuffie

L5-31

J. M. McLaren

R2-78

HO- 34

J. E. Meacham

R2-32

S. J. Mech

J. P. Menard

L5-55

R2-40

J. W. Neskas

R2-11

N. J. Milliken

$\mathrm{H} 4-62$

A. F. Noonan

P. C. Ohl

R2-12

M. A. Payne

H5-09

R. S. Popiel arczyk

R2-50

D. N. Price

$\mathrm{R} 1-30$

J. G. Propson

R2-14

R2-18

Distr-6 


\section{DISTRIBUTION (Continued)}

\section{Number of Copies}

\section{ONSITE}

Westinghouse Hanford Company (continued)

R. E. Raymond Rl-80

I. E. Reep R2-08

F. R. Reich L5-63

E. L. Renner R2-08

D. A. Reynolds R2-11

D. C. Richardson R2-31

J. H. Roecker B1-59

C. C. Scaief L7-06

C. P. Schroeder L7-06

M. H. Shannon H4-61

N. L. Simon R2-78

B. C. Simpson (10) R2-12

S. R. Tifft H6-16

H. Toffer HO-38

J. D. Thomson R1-30

R. E. Vandercook S6-17

W. T. Watson HO-38

R. K. Welty Rl -80

W. P. Whiting B3 25

J. C. Wiborg H4-60

W. D. Winkelman L L-55

D. D. Wodrich R2-31

D. D. Wodrich B1-59

W. F. Zuroff R2-14

Central Files L8-04

Document Processing and Distribution (2) L8-15

EDMC H6-08

Information Release Administration (3) R1-08

TFIC R1-20 
WHC-EP-0640

This page intentionally left blank.

Distr-8 

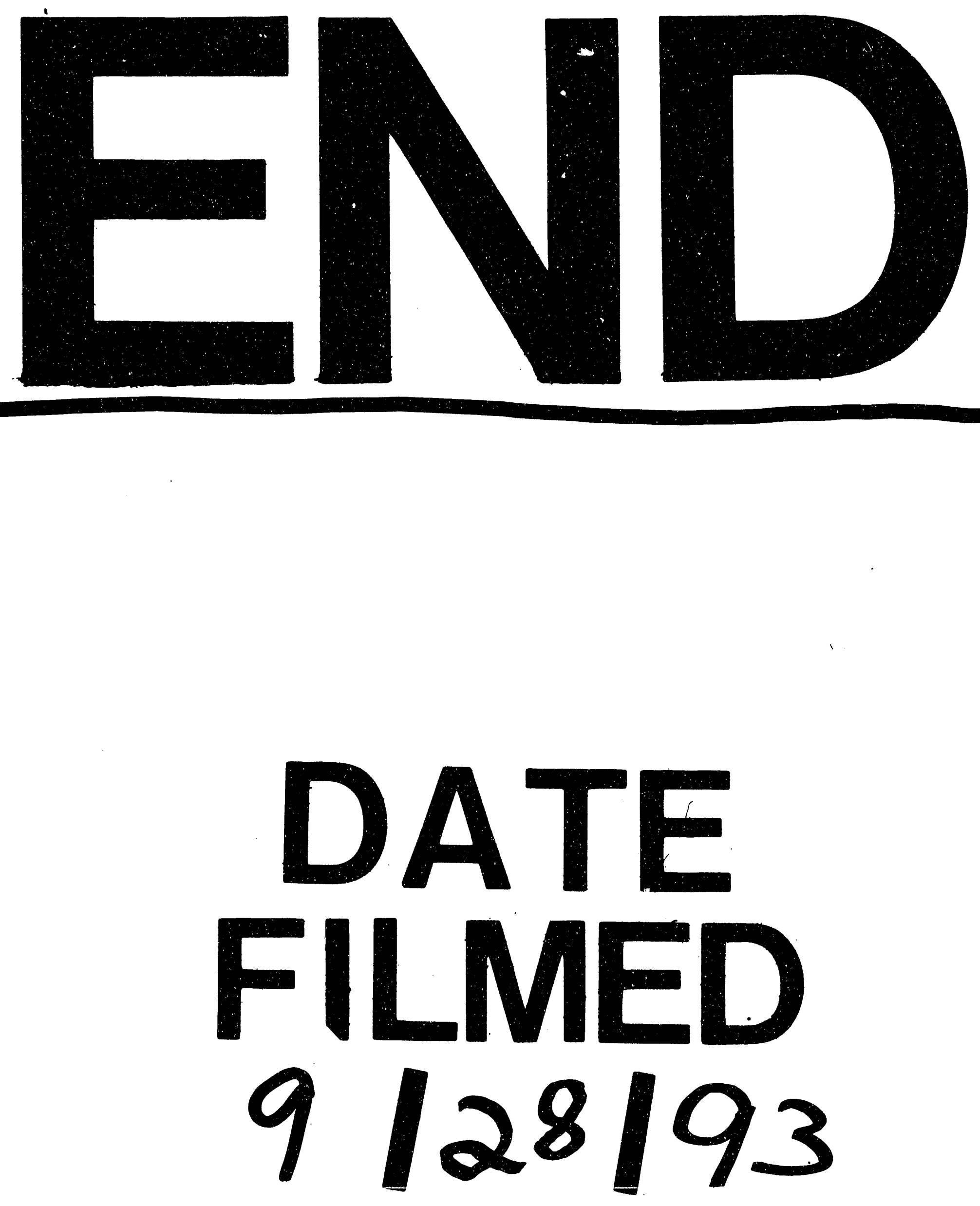
1 